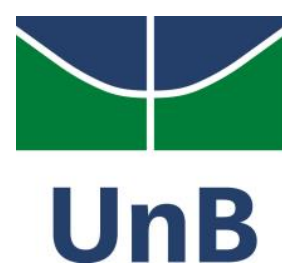

UNIVERSIDADE DE BRASÍLIA

FACULDADE DE COMUNICAÇÃO

PROGRAMA DE PÓS-GRADUAÇÃO

Pesquisas eleitorais e colunismo político na cobertura das eleições presidenciais de Brasil (2014) e Argentina (2015)

ANDRÉ LUÍS SOARES FONTENELLE 


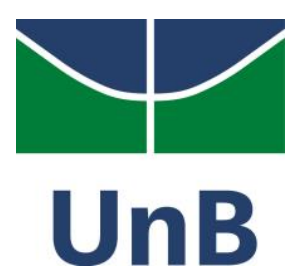

UNIVERSIDADE DE BRASÍLIA

FACULDADE DE COMUNICAÇÃO

PROGRAMA DE PÓS-GRADUAÇÃO

\title{
Pesquisas eleitorais e colunismo político na cobertura das eleições presidenciais de Brasil (2014) e Argentina (2015)
}

\author{
ANDRÉ LUÍS SOARES FONTENELLE
}

\author{
Dissertação apresentada ao Programa de Pós- \\ Graduação em Comunicação da Universidade de \\ Brasília (UnB) como parte dos requisitos para \\ obtenção do título de mestre. \\ Linha de pesquisa: Jornalismo e Sociedade. \\ Orientadora: Prof ${ }^{\mathrm{a}}$. Dr ${ }^{\mathrm{a}}$. Liziane Soares Guazina.
}

Brasília, fevereiro de 2017 


\title{
DISSERTAÇÃO DE MESTRADO
}

\section{Pesquisas eleitorais e colunismo político na cobertura das eleições presidenciais de Brasil (2014) e Argentina (2015)}

\author{
Autor: André Luís Soares Fontenelle \\ Orientadora: $\operatorname{Prof}^{\mathrm{a}} \mathrm{Dr}^{\mathrm{a}}$ Liziane Soares Guazina
}

Dissertação apresentada ao Programa de Pós-Graduação em Comunicação da Universidade de Brasília (UnB) como parte dos requisitos para obtenção do título de mestre pela banca composta pelos membros:

\section{BANCA}

Prof $^{\mathrm{a}}$ Dr $^{\mathrm{a}}$ Liziane Soares Guazina

Faculdade de Comunicação, Universidade de Brasília (Presidente)

Prof $^{\mathrm{a}} \mathrm{Dr}^{\mathrm{a}}$ Flávia Millena Biroli Tokarski

Instituto de Ciência Política, Universidade de Brasília

Prof $^{\mathrm{a}}$ Dr ${ }^{\mathrm{a}}$ Sayonara de Amorim Gonçalves Leal Departamento de Sociologia, Universidade de Brasília

Prof $^{a}$. Dr ${ }^{\mathrm{a}}$. Liliane Maria Macedo Machado Faculdade de Comunicação, Universidade de Brasília (Suplente) 
Por ordem de entrada, para Inês, Alice e Patrícia. 


\section{AGRADECIMENTOS}

A minha orientadora, $\operatorname{prof}^{\mathrm{a}} \mathrm{dr}^{\mathrm{a}}$ Liziane Guazina, por ter acreditado no projeto e pelo crucial insight do estudo comparativo, ensejado pela proximidade das eleições nos países vizinhos.

Aos professores Ana Arruda Callado, Nilson Lage, Sérgio Sant'Anna, Agostinho Dias Carneiro e Geir Campos (in memoriam), por quem valeu a pena estudar na Escola de Comunicação da Universidade Federal do Rio de Janeiro.

Aos professores David Fleischer e Flávia Biroli, pelas valiosas lições no Instituto de Ciência Política da Universidade de Brasília.

Aos colegas Edgard Alves, Leão Serva e Carlos Maranhão, maiores inspirações que tive na carreira.

A Leonard de Assis e Letícia Sorg, pela ajuda no levantamento de informações relativas à metodologia das pesquisas eleitorais e à cobertura jornalística da campanha.

A Carlos Maurício Drummond de Andrade, James Gama, Bernardo Ururahy e colegas do Serviço Multimídia da Agência Senado, pela compreensão.

A meus pais, Edmilson (in memoriam) e Nelyr, por terem infundido em mim a curiosidade que me levou ao jornalismo e à vida acadêmica.

A meu irmão, Luís Eduardo, vocação de jornalista perdida para o Direito.

A Inês e Alice, pela paciência com o pai atarefado.

A Patricia Pinheiro, por ter levado pés-de-pato a uma ilha deserta. 
C'est le spectacle burlesque de cette sphère politique hyper représentative de rien du tout, que les gens dégustent à travers les sondages et les médias.

BAUDRILLARD, Le politique et la simulation (1978) 


\section{Pesquisas eleitorais e colunismo político na cobertura das eleições presidenciais de Brasil (2014) e Argentina (2015)}

\section{RESUMO}

As pesquisas de intenção de voto se tornaram um elemento incontornável da cobertura das campanhas eleitorais pelos meios de comunicação. Historicamente, têm sido utilizadas como base de matérias jornalísticas e análises sobre a campanha eleitoral. Boa parte dos textos dos colunistas emprega os números de pesquisas eleitorais. Mas, de que forma essas pesquisas amparam a construção, pela mídia, de suas estratégias argumentativas, com vistas ao agendamento e ao enquadramento do debate político? Para compreender como se dá esse uso das pesquisas pelos meios de comunicação analisaram-se 170 textos de quatro comentaristas políticos de grande prestígio de meios de comunicação de referência ( $O$ Estado de S. Paulo e $O$ Globo, no Brasil; Clarín e La Nación, na Argentina), relativos às campanhas presidenciais ocorridas nesses países, respectivamente, em 2014 e 2015. Também foram analisados aspectos metodológicos e jurídicos que impõem certas restrições ao uso das pesquisas pelos meios de comunicação, ou as tornam sujeitas a erros ou manipulações. A análise dos textos confirmou o extenso uso das pesquisas na produção de enquadramentos que se assemelham entre si, tanto dentro do colunismo de cada país quanto entre os colunismos dos dois países, apropriando-se, para impor determinada construção da realidade, do caráter de cientificidade que o campo das ciências sociais atribui a esse tipo de levantamento. Entre os enquadramentos relacionados às pesquisas encontram-se a omissão dos candidatos "mal colocados"; a omissão da ocorrência de outros pleitos majoritários e proporcionais; a pregação do "voto útil" em favor de determinados candidatos; e a atribuição ao eleitorado de anseios, como o de mudança, com base em pesquisas pouco aprofundadas. As pesquisas servem, portanto, não como instrumento de interpretação e previsão do comportamento do eleitorado, e sim de agendamento e enquadramento de temas do debate político, com propósito persuasivo.

Palavras-chave: Pesquisas eleitorais. Colunismo político. Eleições, Brasil. Eleições, Argentina. 


\title{
Electoral polls and political columnists in the coverage of the presidential elections of Brazil (2014) and Argentina (2015)
}

\begin{abstract}
Electoral polls have become an inescapable element of the media coverage of election campaigns. They have been used historically as a basis for journalistic texts and analyses of those campaigns. Many of the columnists' texts employ polls' numbers. But in which ways do opinion polls support the construction, by the media, of their persuasion strategies, to set the agenda and frame the political debate? In order to understand how the media uses opinion polls, we have analyzed 170 opinion texts by four renowned political analysts of leading media ( $O$ Estado de $S$. Paulo and $O$ Globo of Brazil; Clarín and La Nación of Argentina) during the respective presidential campaigns of those countries, in 2014 and 2015. We also analyzed some methodological and legal aspects that impose certain restrictions on the use of research by the media, or make them subject to errors or manipulations. The analysis of the texts confirmed the extensive use of opinion polls in the production of framings that resemble each other, both within the columnists of each country and between those of the two countries, appropriating, to impose a certain construction of reality, the character of scientificity that the social science field attributes to this type of survey. Some of the frames related to opinion polls we have found include the omission of "underdog" candidates; the omission of other majoritarian and proportional elections; the preaching of strategic voting in favor of certain candidates; and the attribution of certain wishes to the voters, like the "wish of change", based on little in-depth data..The opinion polls serve, therefore, not as an instrument of interpretation and prediction of the behavior of the electorate, but as a means of setting the agenda and framing certain topics of the political debate, with a persuasive purpose.
\end{abstract}

Keywords: Electoral polls. Political columnists. Elections, Brazil. Elections, Argentina. 


\section{SUMÁRIO}

\section{LISTA DE ILUSTRAÇÕES}

Gráfico 1 - Pesquisas Datafolha, eleição brasileira de 2014 (primeiro turno). .71

Gráfico 2 - Pesquisas Ibope, eleição brasileira de 2014 (primeiro turno) . .72

Gráfico 3 - Pesquisas Poliarquía, eleição argentina de 2014 (primeiro turno) .78

Gráfico 4 - Pesquisas Management \& Fit, eleição argentina de 2014 (primeiro turno) 79

\section{LISTA DE TABELAS}

Tabela 1 - Legislação referente a pesquisas eleitorais nos países da América Latina ....47

Tabela 2 - Mecanismos de controle das pesquisas nos países da América Latina . .48

Tabela 3 - Países da América Latina segundo o grau de controle da realização e divulgação de pesquisas.

Tabela 4 - Restrição temporal à divulgação de pesquisas nos países da América Latina

Tabela 5 - Informações técnicas sobre as pesquisas eleitorais exigidas pela legislação nos países da América Latina....

Tabela 6 - Exigência de registro das empresas de pesquisas nos países da América Latina

Tabela 7 - Semelhanças entre as conjunturas político-econômicas de Brasil (2014) e Argentina (2015)

Tabela 8 - Características dos sistemas político-eleitorais brasileiro (2014) e argentino (2015)

Tabela 9 - Legislação relativa a pesquisas eleitorais no Brasil e na Argentina .64

Tabela 10 - Funções e objetos dos enquadramentos noticiosos, segundo Entman.....

Tabela 11 - Características dos sistemas mediáticos brasileiro e argentino segundo os critérios de Hallin e Mancini

Tabela 12 - Menções aos candidatos da campanha presidencial em curso nas colunas de Pereira, Kramer, Morales Solá e Van der Kooy 106 
Tabela 13 - Menções a outros políticos e personalidades (por exemplo, assessores) envolvidos com a campanha nas colunas de Pereira, Kramer, Morales Solá e Van der Kooy 108

Tabela 14 - Menções a outras campanhas (estaduais/provinciais ou legislativas) nas colunas de Pereira, Kramer, Morales Solá e Van der Kooy 109

Tabela 15 - Menções a governos anteriores nas colunas de Pereira, Kramer, Morales Solá e Van der Kooy 110

Tabela 16 - Menções a pesquisas eleitorais ou a subgrupos do eleitorado nas colunas de Pereira, Kramer, Morales Solá e Van der Kooy.....

Tabela 17 - Menções a empresas de pesquisas nas colunas de Pereira, Kramer, Morales Solá e Van der Kooy.....

Tabela 18 - Temas relativos à campanha de Dilma Rousseff nas colunas de Pereira e Kramer

Tabela 19 - Temas relativos à campanha de Marina Silva nas colunas de Pereira e Kramer

Tabela 20 - Temas relativos à campanha de Aécio Neves nas colunas de Pereira e Kramer

Tabela 21 - Temas relativos à campanha de Daniel Scioli nas colunas de Morales Solá e Van der Kooy

Tabela 22 - Temas relativos à campanha de Mauricio Macri nas colunas de Morales Solá e Van der Kooy. 118

Tabela 23 - Temas relativos à campanha de Sergio Massa nas colunas de Morales Solá e Van der Kooy.....

Tabela 24 - Funções e objetos dos enquadramentos nas colunas de Dora Kramer na campanha eleitoral brasileira de 2014, a partir dos critérios de Entman

Tabela 25 - Funções e objetos dos enquadramentos nas colunas de Merval Pereira na campanha eleitoral brasileira de 2014, a partir dos critérios de Entman

Tabela 26 - Funções e objetos dos enquadramentos nas colunas de Eduardo van der Kooy na campanha eleitoral argentina de 2015, a partir dos critérios de Entman 124

Tabela 27 - Funções e objetos dos enquadramentos nas colunas de Joaquín Morales Solá na campanha eleitoral argentina de 2015, segundo os critérios de Entman 124 
Prólogo

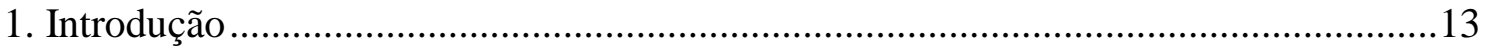

1.1. "Se a eleição fosse hoje...”: o que as pesquisas pesquisam? ........................26

1.2. Questões metodológicas das pesquisas ........................................................30

1.3. Gallup, Ibope e as origens das pesquisas de opinião ..................................35

1.4. O discurso científico das pesquisas .............................................................39

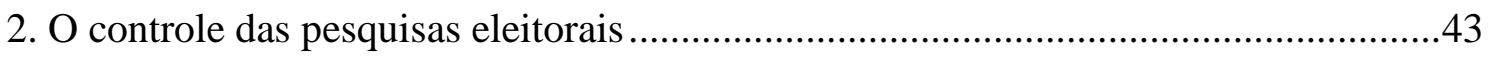

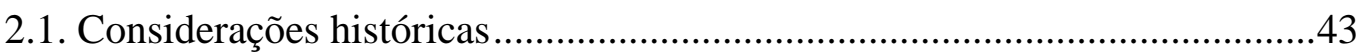

2.2. A influência das pesquisas.....................................................................4

2.3. Restrições à realização e divulgação de pesquisas ........................................44

2.4. Leis, acórdãos e regulamentos na América Latina ......................................46

2.5. O debate sobre o controle das pesquisas na América Latina ........................53

2.6. O debate atual sobre o uso das pesquisas .................................................57

3. Brasil e Argentina: um estudo comparado .............................................................61

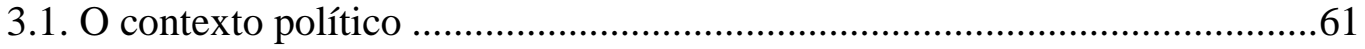

3.1.1. A eleição presidencial brasileira de 2014 ....................................65

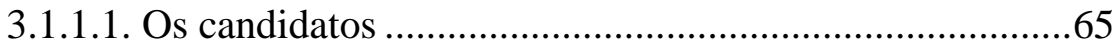

3.1.1.2. Cronologia da campanha eleitoral ...............................67

3.1.1.3. Números das pesquisas eleitorais ..................................69

3.1.2. A eleição presidencial argentina de 2015 ...................................73

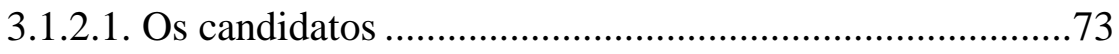

3.1.2.2. Cronologia da campanha eleitoral............................... 75

3.1.2.3. Números das pesquisas eleitorais .................................76

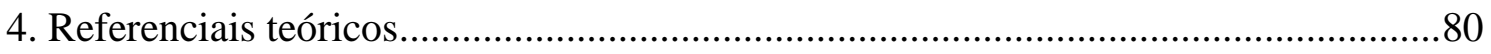

4.1. Bourdieu, o conceito de campo e a "opinião pública" ................................80

4.2. Goffman, Entman e o enquadramento ........................................................ 83

4.3. Enquadramento, mídia e política no Brasil...............................................89 
4.5. Hallin, Mancini e os estudos comparativos .............................................92

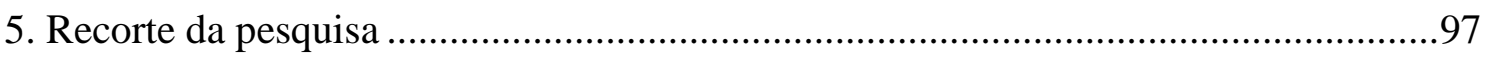

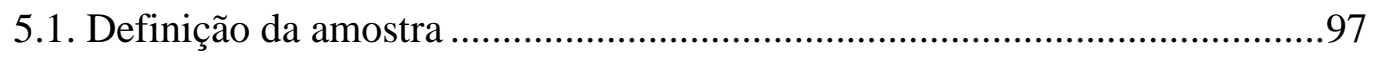

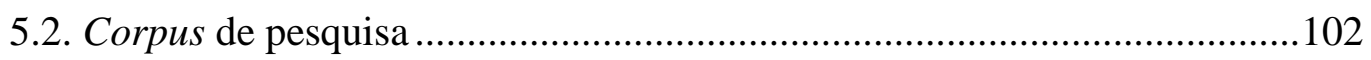

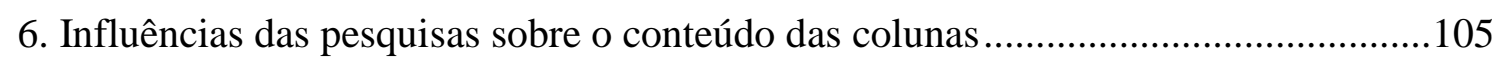

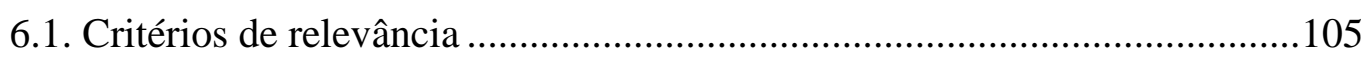

6.2. A agenda da mídia e dos colunistas ......................................................113

6.3. Elementos comuns no enquadramento dos artigos ..................................119

6.4. Enquadramentos relacionados às pesquisas...........................................125



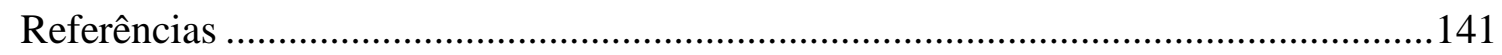

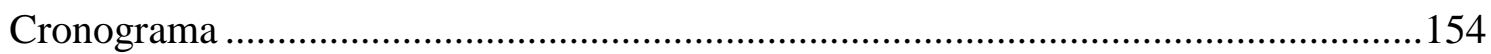

Apêndice I - Temas da agenda da campanha eleitoral no Brasil (2014) e na Argentina (2015), mencionados nas colunas analisadas ............................................................. 155

Apêndice II - Manchetes de $O$ Estado de S. Paulo e de $O$ Globo relativas a pesquisas eleitorais, no período entre 15 de agosto e 26 de outubro de 2014 ................................ 164

Apêndice III - Manchetes do Clarín e de La Nación relativas a pesquisas eleitorais, no período entre 19 de agosto e 22 de novembro de 2015 


\section{Prólogo}

O mês era novembro de 1982 e, colados ao rádio-gravador na sala de um apartamento em Copacabana, eu e meu irmão, então com 11 e 12 anos, esperávamos com ansiedade o Informe $J B$, noticiário da Rádio Jornal do Brasil, em que o repórter Pery Cotta traria o boletim mais recente com a contagem dos votos das eleições para o governo fluminense. Em casa éramos leitores de $O$ Globo, e por isso tínhamos contato com os dois lados daquilo que viria a ser conhecido como o Caso Proconsult, o escândalo que envolveu a apuração daquele pleito: enquanto o jornal de Roberto Marinho mostrava Moreira Franco, candidato da ditadura, à frente, a contagem paralela da Rádio Jornal do Brasil projetava o triunfo de Leonel Brizola, então o político mais temido pelo regime.

A vitória de Brizola acabaria confirmada, a suspeita de uma conspiração para fraudar a contagem e impedir sua eleição sempre pairaria sobre aquela apuração, e meu interesse pela política e pelo jornalismo só faria crescer. Duas décadas de carreira em redações proporcionaram a oportunidade de participar de equipes de cobertura de algumas campanhas políticas, como nas eleições municipais de 1996 na Folha de S. Paulo e presidenciais de 2010 pela revista Época, sempre com grande interesse pelos números das pesquisas e da apuração dos votos. $\mathrm{O}$ amor pelo jornalismo, pela política e pelos números suscitou, ao longo dos anos, a inquietação em relação à forma como as pesquisas eleitorais são utilizadas pela imprensa nas coberturas eleitorais. As peculiaridades da eleição presidencial de 2014, em que a morte do candidato Eduardo Campos embaralhou as análises e os números das sondagens, foram o ponto de partida do questionamento por trás do presente trabalho. 


\section{Introdução}

Em março de 1945 o Diário da Noite, do Rio de Janeiro, publicou aquilo que chamou de "a primeira pesquisa política realizada pelo Instituto Brasileiro de Opinião Pública e Estatística". Tratava-se de uma novidade para a época: um levantamento das preferências do eleitorado carioca, meses antes daquela que seria a primeira eleição presidencial no país desde a instauração do Estado Novo varguista ${ }^{1}$. A empresa responsável, o Ibope, fora criada apenas três anos antes por Auricélio Penteado, homem vindo do ramo da publicidade e que trouxera dos Estados Unidos os métodos de George Gallup, pioneiro das pesquisas de opinião. ${ }^{2}$ O Ibope vinha adquirindo certa notoriedade com seus levantamentos das preferências dos ouvintes de rádio, no Rio de Janeiro e em São Paulo. Pela primeira vez o público - e em particular o mercado publicitário - podia saber com alguma precisão que programas atraíam mais ou menos audiência. O potencial de controvérsia dessa informação era evidente: as emissoras desfavorecidas nos levantamentos do Ibope não tardariam a externar seu descontentamento.

A mecânica das pesquisas por amostragem era, então, totalmente desconhecida do público. Era natural que fossem questionados os métodos que Penteado tentava propagar no Brasil. Por isso, ele se dedicou a uma série de palestras, entrevistas e artigos em que explicava os fundamentos científicos que permitiam que, com pouco mais de mil entrevistas, se conhecessem as preferências de um universo de milhões de pessoas. ${ }^{3}$

No caso das eleições, tanto quanto no das audiências de rádio, o risco de polêmica é facilmente compreensível. Queixas sobre a imprecisão das pesquisas são tão antigas quanto as próprias pesquisas. Mas era um período em que a crença positivista na

\footnotetext{
${ }^{1}$ A título de curiosidade histórica, registre-se o resultado da pesquisa. Ela atribuía 49,5\% das preferências ao brigadeiro Eduardo Gomes, candidato apoiado pelo Diário, e 19,4\% ao general Eurico Gaspar Dutra. A pesquisa também dividia os eleitores por "grau de cultura", em classes A, B e C. Dutra levava vantagem apenas na classe $C$, "de cultura rudimentar", nas palavras do jornal. Na eleição propriamente dita, seis meses depois, o brigadeiro teria $37,5 \%$ dos votos válidos na cidade do Rio (então Distrito Federal), contra 33,9\% de Dutra (que venceu a eleição no âmbito nacional).

${ }^{2}$ Gallup ajudou a criar empresas de pesquisa em outros países, como o Reino Unido, e emprestava o próprio nome a iniciativas do gênero, mesmo sem se envolver com elas pessoalmente (CLYMER, 1984).

${ }^{3}$ Em 1945 a cidade do Rio de Janeiro tinha cerca de 2 milhões de habitantes, e a de São Paulo, aproximadamente 1,7 milhão, numa estimativa com base nos censos de 1940 e 1950.
} 
ciência tinha grande força. Essa crença já vinha sofrendo abalos em alguns círculos. O clássico de Karl Popper A Lógica da Descoberta Científica, que questionava a natureza do conhecimento científico e viria a ter grande influência sobre a filosofia da ciência, foi publicado em alemão em 1934, mas só ganharia tradução para o inglês em 1959. Tamanha era a fé no progresso da ciência que até mesmo o lançamento da primeira bomba atômica sobre Hiroshima, naquele mesmo ano de 1945, seria saudada por boa parte da imprensa mundial como "uma revolução científica", deixando em segundo plano as considerações morais e humanas. Vivia-se um período de mudança de paradigma, na definição que lhe dá Kuhn (1970).

No caso das pesquisas, a confiança na capacidade destas de prever o resultado eleitoral levou Penteado a um vaticínio otimista, nas mesmas páginas do Diário da Noite que anunciavam a primeira pesquisa política da história brasileira:

\begin{abstract}
Ante as sucessivas confirmações das previsões de Gallup e outros pesquisadores, em matéria eleitoral, já ninguém mais duvida de que o processo de consultas populares por meio de amostra seja quase infalível, quando planejada e executada a pesquisa de acordo com certas exigências técnicas (...). Não seria mesmo exagerado prever-se para um futuro talvez não remoto a substituição da estatística dos grandes números pelo processo de amostra, até para eleições municipais, estaduais e nacionais. E tais eleições, levadas a efeito por consultas populares do tipo das de Gallup, rigorosamente controladas por técnicos e fiscalizadas pelos partidos, não seriam menos verdadeiras que o escrutínio geral, muito mais demorado, caro e trabalhoso. (Diário da Noite, 27 mar. 1945)
\end{abstract}

A reação inicial, ao ler o trecho acima nos dias de hoje, pode ser de hilaridade. Afinal, sete décadas depois, sabemos que as eleições continuam a ocorrer, não tendo sido substituídas pelas pesquisas eleitorais. Muitos pleitos são decididos por diferenças de votos inferiores à margem de erro das pesquisas, o que bastaria para explicar por que a utopia de Penteado é impraticável. Conhecer a opinião de cada eleitor continua a ser necessário, por mais caro e complexo que seja. ${ }^{5}$

\footnotetext{
${ }^{4}$ Foi exatamente essa a expressão usada pelo diário francês Le Monde, no dia seguinte à explosão, em sua manchete de primeira página. Aos olhos do leitor de hoje, chama a atenção a aparente insensibilidade diante da dramática perda de milhares de vidas humanas.

${ }^{5}$ Em 2014 o Tribunal Superior Eleitoral estimava em $R \$ 4,80$ o custo por eleitor da organização de uma eleição nacional, ou um custo aproximado de R\$ 685 milhões (TRIBUNAL SUPERIOR ELEITORAL, 2014). Uma pesquisa por amostragem de quotas, de âmbito nacional, alcança resultado aproximado por pouco mais de R\$ 100 mil, segundo se depreende dos registros de pesquisas no TSE.
} 
Penteado pode não ter acertado sua previsão de maneira literal. Mas, de certa forma, a "estatística pelo processo de amostra", para usar sua expressão, substituiu em grande parte as eleições. Sim, a cada quatro anos continuamos a ir as urnas para eleger nossos representantes. Mas fora do período eleitoral o debate político é agendado pelas pesquisas: elas nos informam, a intervalos cada vez menores ${ }^{6}$, quem seria o presidente da República "se a eleição fosse hoje" ; e informam os "índices de popularidade" dos eleitos, influindo diretamente em sua legitimidade junto à classe política e aos cidadãos. Os governantes consultam permanentemente esses índices, que guiam boa parte de suas decisões, acarretando o risco de um populismo guiado pelas pesquisas por amostragem, o que levou o filósofo francês Bernard-Henri Lévy a ironizar, em artigo recente onde se percebem ecos involuntários do desejo formulado por Penteado sete décadas atrás:

\begin{abstract}
Ah, sonha o populista, se fosse possível, de uma vez por todas, substituir as eleições pelas pesquisas! Se fosse possível transformar a República em concurso de TV; a eleição, em plebiscito; o público, em audiência8 - se fosse possível pôr fim ao público e consagrar o "grande animal" de Platão ou essa plebe que, segundo os sofistas, deveria substituir o demos. (LÉVY, 2016)
\end{abstract}

As pesquisas não substituíram as eleições, bem como a amostragem não substituiu o povo, mas em várias outras áreas elas se impuseram como ferramenta de análise. Pesquisas por amostragem orientam todo tipo de decisão na sociedade: lançamento de produtos nos supermercados, alterações na programação de televisão, correções no discurso dos políticos, hipóteses acadêmicas nas ciências sociais. Isto não é necessariamente um problema: mesmo imprecisa, a pesquisa fornece, para diversos fins, uma aproximação satisfatória da realidade.

Nosso desejo de previsibilidade ajuda a entender o sucesso das pesquisas. Todos nós, o tempo todo, tomamos decisões baseadas em previsões, próprias ou alheias. Decidimos que roupa usar, se saímos de casa com um guarda-chuva ou se vamos viajar com base na meteorologia ou em nossa própria experiência em relação ao tempo;

\footnotetext{
${ }^{6}$ Existem trackings diários que monitoram "em tempo real" as tendências do eleitorado. Os meios de comunicação não podem divulgar os resultados desses levantamentos em período de campanha eleitoral, em razão das restrições da legislação, que serão abordadas no Capítulo 2.

${ }^{7}$ Em junho de 2015, o Datafolha divulgou pesquisa sobre a eleição presidencial prevista para outubro de 2018, ou seja, dali a mais de três anos.

${ }^{8}$ No sentido de "audiência de TV" (no original em francês, Audimat).
} 
aplicamos nossas economias em investimentos recomendados por especialistas ou seguindo nossa intuição quanto aos rumos da economia; escolhemos nossa profissão, nossa residência, nosso cônjuge em função de determinadas expectativas sobre o futuro, que nada garante que virão a se confirmar. ${ }^{9}$

A pesquisa eleitoral, porém, é "uma predição do presente", na expressão de Bouza (1998, p. 50): "Não tem nada a ver com o futuro, embora possa ser usada para o prognóstico". Sacia, até certo ponto, a sede de previsibilidade em relação ao futuro político. A vitória de um ou outro candidato é um desfecho que afeta, direta ou indiretamente, a vida de todos os cidadãos, mesmo aqueles que não votam. Isso explica em boa parte o interesse que desperta nos meios de comunicação. Em períodos de campanha eleitoral, jornais usam pesquisas em suas manchetes como apelo de vendas. Como mostra o Apêndice II deste trabalho, as pesquisas eleitorais constituíram a manchete principal de $O$ Estado de S. Paulo 16 vezes nos 70 dias que antecederam as eleições, e a manchete principal de $O$ Globo 13 vezes no mesmo período. Nas eleições presidenciais brasileiras entre 1989 e 2010, os três maiores diários brasileiros do período, Folha, $O$ Globo e $O$ Estado de S. Paulo, publicaram ao todo 906 pesquisas (BIROLI, MIGUEL e MOTA, 2011, p. 76).

Especialistas que adquiriram reputação de bons "previsores" de resultados tornaram-se respeitados consultores e autores de best sellers. A arte (ou ciência) da análise de pesquisas e resultados eleitorais ganhou até um nome erudito: psefologia, do grego psephos, "pedregulho" ou, em sentido figurado, "voto" - os gregos da Antiguidade, fundadores da democracia, depositavam pedras brancas ou pretas em urnas para votar "sim" ou "não".

Nos Estados Unidos, berço das pesquisas, especialistas em interpretá-las chegam a adquirir fama nacional. Nate Silver, estatístico oriundo do beisebol, aplicou as leis da matemática à identificação de tendências do eleitorado, a partir de índices de pesquisas e resultados de pleitos anteriores. Ganhou fama com o blog FiveThirtyEight (referência aos 538 delegados do "colégio eleitoral" que elege, pelo sistema indireto americano, o presidente dos Estados Unidos), no sítio do jornal The New York Times na internet. Empregando outros métodos, o professor de marketing J. Scott Armstrong e o cientista

\footnotetext{
${ }^{9}$ Silver (2012) e Tetlock e Gardner (2015) traçam panoramas da busca humana por informações que permitam prever or futuro.
} 
político Bruce Bueno de Mesquita previram desfechos de eleições e de eventos da política internacional. Embora o prestígio de vários desses especialistas tenha sido abalado pelo resultado da eleição presidencial americana de 2016, cujo resultado contrariou-lhes as previsões, nada indica que a atividade de "guru de pesquisas" desaparecerá em futuros ciclos eleitorais.

No Brasil, um grande jornal, a Folha de S. Paulo, decidiu criar nos anos 1980 seu próprio departamento de pesquisas, o Datafolha, que abastece a redação com pautas produzidas a partir dos levantamentos que realiza. Outrora reservada para a primeira página do jornal do dia seguinte, a divulgação do resultado das pesquisas passou a ser antecipada nos telejornais da noite anterior. Na eleição presidencial de 2014 o portal de notícias UOL, pertencente ao mesmo grupo da Folha e do Datafolha, antecipou-se até aos telejornais, divulgando em primeira mão, ao vivo, da redação do jornal, os números dos levantamentos minutos após o encerramento da tabulação e ponderação das entrevistas.

Infelizmente para os interessados em previsibilidade, o aperfeiçoamento das técnicas estatísticas, o refinamento da apuração de dados sociais e a velocidade cada vez maior na realização e publicação das pesquisas eleitorais não têm se refletido necessariamente numa maior capacidade de prever os resultados finais das urnas.

A eleição presidencial brasileira de 2014 foi, nesse sentido, exemplar. Um episódio daquela campanha deixou patente a dificuldade dos analistas em compreender o comportamento dos eleitores a partir dos números e despertou o interesse na realização deste trabalho: a ascensão e queda nas pesquisas de Marina Silva, a candidata do Partido Socialista Brasileiro (PSB). Guindada à condição de cabeça de chapa em virtude da morte do candidato original do partido, o ex-governador de Pernambuco Eduardo Campos, Marina atingiu nas primeiras pesquisas que incluíam seu nome índices que levaram os comentaristas a dar como provável (e até mesmo certa) sua vitória nas urnas. Tão rapidamente quanto subiu nos gráficos, porém, Marina caiu, não tendo sequer chegado ao segundo turno da eleição.

A velocidade com que esses acontecimentos se produziram - transcorreram apenas oito semanas entre a morte de Campos, num acidente aéreo, e o primeiro turno da eleição - deu relevo ainda maior à incongruência entre as previsões dos analistas e o resultado final. Às vésperas da eleição, tanto jornalistas quanto cientistas políticos, 
convidados aos estúdios de televisão na condição de autoridades em eleições, emitiram pareceres sobre as tendências do eleitorado que seriam cabalmente desmentidos poucos dias depois. Transcrevemos, por exemplar, trecho do programa Canal Livre exibido oito dias antes do primeiro turno da eleição pela TV Bandeirantes. Nele, entrevistados por um painel de jornalistas, o cientista político Antônio Lavareda e o diretor do Datafolha, Mauro Paulino, davam como diminutas as chances do candidato Aécio Neves, do PSDB (Partido da Social Democracia Brasileira), que, no entanto - repita-se -, apenas oito dias depois acabaria superando Marina por 12,7 milhões de votos, ou mais de 12 pontos percentuais de diferença, índice muito acima da "margem de erro" de qualquer pesquisa:

RICARDO BOECHAT (apresentador): (...) De quantos candidatos nós vamos conversar hoje aqui sobre... quantos candidatos com possibilidades reais de chegar ao segundo turno? Em outras palavras, Aécio Neves ainda está no jogo ou não está? Paulino.

MAURO PAULINO: É uma possibilidade que não dá para descartar, a ida de Aécio para o segundo turno. Como não dá para descartar ainda a ida... a resolução da eleição já no primeiro turno. Mas são duas possibilidades com menos peso do que a possibilidade maior, hoje, que é de Dilma e Marina disputarem o segundo turno.

BOECHAT: Lavareda.

ANTÔNIO LAVAREDA: Dito de outra forma: são possibilidades remotas. Hoje o que é plausível é o segundo turno Dilma-Marina. (Canal Livre, 27 set. 2014)

Em 6 de outubro, um dia após o primeiro turno, Lavareda travou outro diálogo significativo, no programa Roda Viva, da TV Cultura, com a jornalista Eliane Cantanhêde, à época na Folha de S. Paulo:

ELIANE CANTANHÊDE - A minha pergunta é uma provocação, porque um passarinho me contou que no dia do enterro do Eduardo Campos, no Recife, você comentou, numa roda em que esse passarinho estava, comentou afirmativamente: "O Aécio está morto". Ele ressuscitou? O que é que aconteceu?

ANTÔNIO LAVAREDA - Não. Quem estava morto, na verdade, naquele momento, era uma situação fúnebre... O ex-governador Eduardo Campos, era o dia do sepultamento do ex-governador Eduardo Campos. E o comentário feito naquele momento, e que o jornalista, o passarinho, que é um amigo comum nosso (risos), comentou é que eu disse: "Olha, o acidente de avião produziu nesse momento um céu para o Eduardo, a sua figura ganhou ainda mais projeção nacional, e o país todo passou a conhecê-lo naquela circunstância, e abriu a porta do inferno para a candidatura do Aécio”, porque (...) já era possível ver naquele momento, Eliane, que iniciava-se um período de grandes dificuldades para a candidatura do Aécio, como o tempo e as próximas pesquisas viriam revelar. Ou seja, é o tipo de prognóstico para a conjuntura a 
seguir que qualquer um poderia fazer. Não precisava sequer ser especialista na minha área. (Roda Viva, 6 out. 2014)

Para não nos restringirmos às previsões dos cientistas políticos, mencionamos abaixo três outros exemplos, extraídos de colunas escritas por jornalistas quando Marina aparecia no auge das "intenções de voto" nas pesquisas:

Aécio Neves (PSDB) e seus $15 \%$ de intenção de voto empurram os tucanos para fora do protagonismo do debate político nacional depois de mais de duas décadas. Essa tendência foi vista logo depois da morte de Eduardo Campos, na pesquisa realizada pelo Datafolha nos últimos dias 14 e 15 . No início desta semana, o Ibope mostrou a onda pró-Marina. Agora, o Datafolha confirma o que pode ser a cristalização do quadro. (RODRIGUES, 2014)

Para se manter no topo das pesquisas até outubro, Marina talvez não precise fazer nada além de desviar dos laranjas do jato de Eduardo Campos ${ }^{10}$ e cuidar das suas boas maneiras. Prevalecendo a bordo do PSB e de sua coligação diminuta, chegaria ao Planalto sem dever nada a ninguém, exceto aos donos dos votos. Diz-se que pode terminar em desastre. Mas o eleitor, de saco cheio, parece cada dia mais disposto a assumir o risco de, no mínimo, cometer um erro diferente. (SOUZA, 2014)

Passado o trauma da morte de Eduardo Campos e assimilada a chegada triunfal de Marina Silva, a economia retoma o centro do debate eleitoral. (...) Dilma e Mantega culpam o cenário internacional. Marina, rumo à vitória [grifo nosso], e Aécio dizem que não é bem assim (...) (CANTANHÊDE, 2014)

Nenhum analista, fosse ele jornalista ou acadêmico, foi capaz de prever corretamente o resultado das urnas, com base nos números das pesquisas. Dias após o primeiro turno, Hélio Schwartsman, articulista da Folha de S. Paulo, resumiu o sentimento de perplexidade despertado pelo resultado efetivo:

O resultado da eleição surpreendeu? É claro que sim. Poucos dias atrás, eu, a torcida do Corinthians e a maioria dos analistas considerávamos Aécio carta fora do baralho, mas é ele e não Marina quem disputará o segundo turno com Dilma. O que ocorreu? Poderíamos jogar a toalha e dizer que a política não é pautada pela lógica, desistindo de qualquer tentativa de previsão. Mas, antes de entregar os pontos, imaginemos um antropólogo marciano que tenha visitado o Brasil em julho, quando Dilma liderava e Aécio vinha em segundo, e que tenha retornado ontem. Para o marciano, não houve surpresa alguma. (...) Sob essa perspectiva, não só há lógica por trás do processo eleitoral como ela se mantém a mesma desde o início da corrida. (...) E Marina? Marina foi o ruído (...). Vimos a subida de Marina como se fosse um fait accompli, quando não era mais que uma tentativa dos eleitores de formar um consenso em torno do nome que seria capaz de derrotar Dilma. (SCHWARTSMAN, 2014)

\footnotetext{
${ }^{10}$ Souza refere-se a denúncias de irregularidades relativas à propriedade do jato particular em cuja queda o candidato morreu, escândalo que respingou na campanha de Marina.
} 
Do jornalista não se exige que preveja o futuro. Mas parte da credibilidade do jornalismo provém da expectativa do público de encontrar nos meios de comunicação uma análise que sirva de guia mais ou menos confiável em relação ao futuro. Para Kovach e Rosenstiel (2003, p. 31), autores de um clássico manual dos cursos de graduação em jornalismo, "a principal finalidade do jornalismo é fornecer aos cidadãos as informações de que necessitam para serem livres e se autogovernar". Numa democracia, o cumprimento dessa finalidade passa por uma análise das razões que levam o eleitorado a optar por um candidato, um partido ou uma orientação política. Quando essa análise do quadro eleitoral deixa de ser confirmada pelos fatos, é a credibilidade do jornalismo em geral que sofre um abalo.

Tampouco subsiste a ilusão de que o jornalista seja um observador neutro e imparcial dos acontecimentos. Os meios de comunicação, ao analisar a conjuntura eleitoral, estão estabelecendo a "agenda", aquilo que McCombs e Shaw (1972) definiram como agenda-setting, ou a teoria da "construção da agenda" ou do “temário". Segundo Berger e Luckmann (1991, p. 79), formuladores da teoria da construção social da realidade, "a sociedade é um produto do homem. A sociedade é uma realidade objetiva. O homem é um produto social". A objetividade do mundo institucional, na visão desses autores, é uma produção humana, e só adquire status ontológico no âmbito da atividade humana que a produziu. Semprini (1997, p. 59) afirma que "a realidade social não tem existência independente dos atores que a fabricam, das teorias que lhe dão forma e da linguagem que permite conceituá-la e comunicá-la".

Os meios de comunicação são um importante construtor da realidade social. Ao publicarem análises políticas, estão construindo a realidade, pois ainda que as motivações dos eleitores sejam diversas daquelas que lhes atribuem os analistas, as hipóteses destes adquirem caráter factual, ou pelo menos são capazes de influenciar os fatos, dada a credibilidade desses veículos (ALDÉ, 2004). Tal autoridade, porém, tem limites. Se o receptor do discurso não reconhece a realidade descrita por esse mesmo discurso, a mídia perde credibilidade (RODRIGO ALSINA, 2009). Essa perda pode ser pontual - erros nas pesquisas, por exemplo, comprometem o contrato fiduciário entre o leitor e seu jornal preferido - ou geral, atingindo toda a mídia. 
Por isso, estudar a forma como os meios de comunicação analisam as pesquisas é relevante para entender a relação de confiança que se estabelece entre a mídia e a sociedade. Se a análise da "autoridade", seja ela o especialista ou a mídia, não difere do palpite do "curioso" das ruas, cai por terra a credibilidade de quem transmite o discurso. É o que, inadvertidamente, Lavareda reconhece, no Roda Viva, em relação à sua própria previsão da "morte” política de Aécio: “É o tipo de prognóstico para a conjuntura a seguir que qualquer um poderia fazer. Não precisava sequer ser especialista na minha área."

Errar previsões nunca inibiu os analistas de continuar a fazê-las. Porém, a rapidez da "reviravolta" na eleição de 2014, que induziu os especialistas a descartar as possibilidades de Aécio Neves, chamou a atenção para a forma como as pesquisas são utilizadas pelos meios de comunicação, motivando esta dissertação. Um exame aprofundado dos argumentos usados pelos analistas - os "enquadramentos", para aplicar um conceito que será explorado mais adiante - mostra que eles guardavam pouca ou nenhuma relação com aquilo que seria possível afirmar apenas com base nos dados disponíveis. Em virtude das próprias características das pesquisas eleitorais, que se limitam na maior parte dos casos a questionários "fechados", estruturados, sabe-se muito pouca coisa sobre a cabeça do entrevistado além de sua “intenção de voto". Apesar disso, ao longo da campanha eleitoral atribuíram-se aos eleitores as mais variadas motivações. Citamos algumas que serão examinadas mais adiante:

- O eleitor de Marina acredita numa "nova política", alicerçada em torno de conteúdos programáticos, e independente dos partidos políticos;

- O eleitor de Dilma está influenciado pela "tática do medo" adotada pelos marqueteiros de seu partido;

- O eleitor, em geral, tem o "anseio de mudança".

Essas construções da realidade, exemplos extraídos das análises publicadas durante a campanha, são perfeitamente plausíveis. $O$ problema é que em praticamente nenhum momento os analistas puderam apontar de onde extraíam os elementos objetivos que lhes permitiam elaborar essas hipóteses de explicação para o comportamento dos votantes. 
Em muitos casos prevaleceram constatações e raciocínios falaciosos, do tipo post hoc ergo propter hoc (Dilma bateu em Marina no horário eleitoral gratuito; Marina caiu nas pesquisas; logo, Marina caiu nas pesquisas porque Dilma bateu nela no horário eleitoral). Pode-se supor que os analistas talvez disponham de dados aos quais o público não tem acesso, como grupos focais e outros tipos de pesquisas. Como se verá, porém, do recenseamento dos textos sobre a campanha eleitoral, nos meios de comunicação, raramente se encontram menções a essas pesquisas como fonte de aprofundamento das análises. Parece-nos que isso não se deve a um desejo de esconder do público a existência ou o uso desse tipo de levantamento qualitativo, ou às restrições impostas pela lei à sua divulgação (pois a essas restrições nunca se faz menção), e sim da simples negligência de seu uso como instrumento de sondagem das tendências do eleitorado.

Antes de acusar os analistas políticos de "incompetência", porém, pelo fato de suas análises não servirem como interpretação ou explicação satisfatória do comportamento do eleitorado, não se pode descartar a hipótese de que, ao contrário, esses mesmos analistas sejam na verdade competentes dentro daquilo a que se propõem na interpretação das pesquisas. STRÖMBACK (2012), analisando as razões pelas quais a mídia demonstra enorme atração pelas pesquisas, observa que "as pesquisas de opinião são a melhor metodologia já inventada para investigar a opinião pública”, para em seguida ressalvar: "[As] pesquisas podem ser bem e mal utilizadas. O mesmo se aplica à cobertura das pesquisas de opinião na mídia”. E acrescenta:

Raramente, ou nunca, os números falam por si, e o tipo de pesquisa
encomendado pela mídia raramente, ou nunca, inclui perguntas suficientes para
investigar o que poderia ter provocado os resultados de uma pesquisa de
opinião específica. Por conseguinte, ao discutir antecedentes ou possíveis
consequências dos resultados das pesquisas de opinião, os jornalistas precisam
interpretar ou especular. Apesar disso, essas interpretações e especulações
tendem a parecer ancoradas nos resultados da pesquisa de opinião, como sendo
factuais. No fim das contas, a cobertura das pesquisas de opinião permite, desta
forma, que os jornalistas sejam interpretativos e proativos, ao mesmo tempo
em que mantêm a aparência de objetividade. (STRÖMBACK, 2012, p. 13)

Se considerarmos o agendamento do debate político e o enquadramento dos temas dessa agenda como objetivos almejados pelos meios de comunicação, é de esperar que tenda a ser descartado todo dado da realidade, objetivo ou subjetivo, que se contraponha aos temas agendados ou aos enquadramentos escolhidos pela mídia. 
Os números das pesquisas eleitorais, dentro dessa lógica, só são úteis na medida em que servem às estratégias argumentativas dos meios de comunicação. As pesquisas seriam, assim, um instrumento de ação política, e os meios de comunicação se amparam nelas como "elemento de verdade" para suas argumentações.

Tomando mais uma vez por base a campanha presidencial brasileira de 2014, extraímos um exemplo da leitura das colunas que formam o corpus deste trabalho. A ascensão de Marina Silva nos números das pesquisas, entre meados de agosto e o final de setembro, poderia (e aqui simplificamos uma realidade reconhecidamente complexa apenas para tornar mais claro nosso argumento) ser explicada de duas maneiras:

- A morte de Eduardo Campos, a quem Marina substitui como cabeça de chapa, provocou grande comoção popular, refletindo-se num ganho de simpatia que se refletiu nas intenções de voto da candidata substituta.

- Marina Silva já dispunha de capital político anterior à morte de Eduardo Campos, talvez até maior que o de seu falecido companheiro de chapa, tendo obtido 19\% dos votos válidos na eleição presidencial anterior, em 2010, e seu bom índice nas pesquisas teria a ver com isso, e não com uma suposta comoção do público.

Outras hipóteses poderiam ser formuladas, assim como não se pode descartar que estas e outras variáveis tenham influenciado ao mesmo tempo o eleitorado, mas nos detenhamos apenas nestas duas, presentes nas colunas dos comentaristas políticos dos jornais. A primeira hipótese, da comoção popular, permitiria supor que, passado o interesse do público pelas circunstâncias dramáticas do acidente aéreo que matou Campos, o eleitorado tenderia a "refluir" aos índices de intenção de voto anteriores. A segunda pressupõe uma menor volatilidade dos eleitores suscetíveis a votar em Marina, aumentando, portanto, sua chance de chegar à eleição com chances de vitória. Nas estratégias argumentativas dos colunistas, a hipótese da comoção popular, presente nos dias subsequentes à morte de Campos, foi progressivamente deixada de lado em favor da segunda hipótese, de um eleitorado consolidado em favor de Marina, sem que os dados brutos das pesquisas proporcionassem evidências em favor de uma ou outra alternativa. Privilegiar uma hipótese em detrimento de outra favorece determinado enquadramento do debate político; neste caso, reforçando uma construção da realidade em que a maioria da "opinião pública" 
desejaria a mudança de governo, com a derrota da candidatura de Dilma Rousseff à reeleição e o triunfo de uma alternativa oposicionista. Neste caso, as pesquisas teriam um papel meramente performático dentro de uma estratégia persuasiva, ficando em segundo plano seu valor como elemento de análise das opiniões dos eleitores num instante isolado da campanha ou ao longo do tempo.

Considerando as questões acima expostas, podemos sintetizar da seguinte forma nossa pergunta de pesquisa: os meios de comunicação se utilizam abundantemente das pesquisas de opinião como base de matérias jornalísticas e análises sobre a campanha eleitoral. Boa parte dos textos dos colunistas emprega os números de pesquisas eleitorais. De que forma essas pesquisas amparam a construção, pela mídia, de suas estratégias argumentativas, com vistas ao agendamento e ao enquadramento do debate político?

O objetivo deste trabalho é investigar como se dá o uso das pesquisas, com base na análise dos textos de colunistas de prestígio da imprensa brasileira e argentina nas campanhas presidenciais mais recentes dos dois países. Nossa hipótese é que as pesquisas eleitorais, com o caráter de cientificidade que lhes é atribuído pelo campo das ciências sociais, configuram um dos principais elementos de agendamento e enquadramento. E que isso se deve ao fato de que, embora as pesquisas sejam apresentadas como elemento de análise, compreensão e previsão do comportamento do eleitorado, na verdade elas servem ao campo do jornalismo como instrumento para agendar e enquadrar temas do debate político.

Durante a realização deste trabalho surgiu outra inquietação: seria esta uma especificidade brasileira? Como se dá o uso das pesquisas como elemento de agendamento e enquadramento em outras sociedades? Um estudo comparado permitiria uma melhor compreensão desse mecanismo? Uma oportunidade de confrontar essa indagação se encontrava no calendário eleitoral latino-americano. Em outubro de 2015, quase um ano exato após a eleição brasileira, os argentinos iriam às urnas para eleger um novo presidente.

O retorno da democracia a vários países da América Latina, nos anos 1980, aumentou o valor do conhecimento da opinião dos cidadãos sobre a agenda política. Acadêmicos de todo o continente se debruçaram sobre o papel das pesquisas na investigação da opinião pública, e a Argentina não ficou alheia a esse processo. 
Segundo Alonso (2003, p. 2), "no marco da comunicação política, as pesquisas de todo tipo vieram a ocupar um papel protagonista no processo de construção e circulação da informação, especialmente pré-eleitoral”.

Por suas características históricas, sociais, políticas e econômicas, Argentina e Brasil têm muito em comum. Alguns aspectos das duas eleições guardavam grande semelhança: governos à esquerda do espectro político, há três mandatos consecutivos no poder, enfrentando a perspectiva de um pleito mais equilibrado que os anteriores, em um ambiente de desgaste da popularidade e deterioração dos indicadores econômicos. Decidimos, a partir dessa constatação, acompanhar atentamente a cobertura dos meios de comunicação argentinos, buscando pontos de convergência (ou divergência) suscetíveis de justificar um estudo comparativo. Além disso, o relativo distanciamento de nosso olhar sobre a realidade argentina nos permitiria compensar, de alguma forma, aquilo que a proximidade em relação à realidade brasileira pudesse prejudicar na objetividade desejável (por mais que utópica) num estudo desta natureza.

Os meios de comunicação argentina empregam as pesquisas da mesma forma, em suas análises? As pesquisas são divulgadas da mesma maneira? As diferenças entre os modelos comunicacionais argentino e brasileiro se refletem na forma como a campanha eleitoral é tratada? Todas essas questões nos pareceram justificativa suficiente para um estudo comparativo que tentasse iluminar o modo de cobrir uma campanha eleitoral na América Latina, nos dias de hoje. O incentivo da professora Liziane Guazina, orientadora desta pesquisa, foi o empurrão decisivo para que a ideia fosse posta em prática.

Mais adiante trataremos das referências teóricas que têm guiado os estudos comparados dos meios de comunicação nos últimos anos. Considerando a pergunta e a hipótese de pesquisa apresentados acima, o objetivo deste estudo é analisar o uso das pesquisas eleitorais pelo jornalismo, identificando textos jornalísticos que tenham se servido das pesquisas para análise das tendências e do comportamento do eleitorado e buscando nesses textos elementos relacionados às pesquisas que permitissem compreender de que forma estas são usadas como instrumento de construção da realidade. 
Para isto, conforme será detalhado mais adiante, usaremos como referenciais teóricos o conceito de campo, de Bourdieu, para analisar as relações entre os campos jornalístico, político e das ciências sociais; os conceitos de agendamento, de McCombs e Shaw (1972), e enquadramento, de Entman (1993); e as categorias de análise propostas por Hallin e Mancini (2004) na realização de estudos comparados de comunicação.

Nos próximos capítulos buscaremos contextualizar as questões propostas neste estudo, inicialmente tentando entender as pesquisas de opinião propriamente ditas e por que elas não se aproximam necessariamente da realidade que afirmam tentar reproduzir. Em seguida, situaremos o contexto em que se desenrolaram as eleições presidenciais brasileira de 2014 e argentina de 2015, apontando similaridades e disparidades entre as conjunturas dos dois países; apresentaremos os referenciais teóricos selecionados para a realização da análise; e por fím procederemos à análise do corpus de artigos de análise selecionados e das circunstâncias em que empregaram as pesquisas eleitorais, de forma a nos capacitarmos a responder à pergunta que originou esta pesquisa e confirmar ou não nossa hipótese de trabalho.

\section{1. "Se a eleição fosse hoje...": o que as pesquisas pesquisam?}

Embora não seja intenção deste trabalho, na expressão muito feliz de Bourdieu (1973, p. 1292), “denunciar de forma mecânica e fácil as pesquisas de opinião”, parecenos necessário, antes de progredir na investigação do tema deste trabalho, conhecer um pouco melhor o mecanismo de realização e divulgação das pesquisas, a metodologia empregada pelas empresas ${ }^{11}$ para chegar a seus resultados e possíveis equívocos em seu uso pelos meios de comunicação.

À primeira vista, estas podem parecer questões que não têm lugar num projeto de pesquisa de comunicação. Tratar-se-ia de tema para um estudo de

\footnotetext{
${ }^{11}$ Neste trabalho evitamos nos referir às empresas de pesquisas como "institutos", termo de uso corrente no Brasil (sem dúvida por influência do nome do lbope), por induzir a uma percepção enganosa: a de que estas seriam entidades de caráter público, semipúblico ou não lucrativo (logo, neutras). Em espanhol usa-se encuestadoras ou consultoras; em inglês, pollsters. Em francês, instituts de sondage vem perdendo terreno em favor de sociétés ou entreprises de sondage (MOCCl, 2000).
} 
estatística ou de ciência política. Porém a intenção, aqui, não é avaliar o fundamento da metodologia das pesquisas, e sim aprofundar o conhecimento a respeito dela naquilo que possa iluminar e fazer entender a capacidade (ou incapacidade) dos analistas políticos de, a partir de seus resultados, explicar o resultado final das urnas. O que se tentará aqui é argumentar que, embora o discurso das empresas de pesquisas apresente as sondagens de intenção de voto como científicas, elas não se encaixam inteiramente na definição de cientificidade proposta por Karl Popper; e que isto tem um impacto sobre seu uso como ferramenta de interpretação e de construção da realidade.

Um problema fundamental das pesquisas eleitorais é que elas partem de um fazde-conta: "Se a eleição fosse hoje, em qual destes candidatos você votaria?"12 Essa formulação, que é uma das mais comuns nas entrevistas sobre intenção de voto, teria um alto poder "preditivo", no entender dos especialistas, por colocar o entrevistado diante de uma situação "real"13. Porém, ela exige, ao contrário, que as duas partes envolvidas acreditem numa fantasia: tanto pesquisado quanto pesquisador sabem que a eleição não ocorrerá "hoje"

Não é difícil compreender o valor, sobretudo (mas não apenas) econômico, de conhecer com antecedência o resultado de uma eleição. Os mercados orientam seu comportamento pelas expectativas em relação ao futuro; a vitória deste ou daquele movimento político implica transformações mais ou menos profundas na sociedade, afetando a repartição de recursos entre os agentes econômicos. Saber de antemão quem será eleito confere uma vantagem potencialmente lucrativa ao detentor dessa informação. É o que justifica, em grande parte, o investimento de dezenas (ou até centenas) de milhares de reais na realização de uma pesquisa eleitoral.

\footnotetext{
${ }^{12}$ Exemplo extraído de uma pesquisa realizada em 2016 pelo Datafolha, uma das principais empresas em atividade no setor de levantamentos eleitorais no Brasil.

${ }^{13}$ Para um exemplo de diretor de instituto de pesquisa entusiasta desta formulação da pergunta, ver Newport (2004).

14 Para ilustrar o problema "filosófico" contido nessa pergunta, bastaria substituí-la por outras, igualmente hipotéticas, que às vezes são feitas por troça: "Se soubesse que hoje é seu último dia de vida, o que você faria?", ou "Se ganhasse na loteria hoje, o que faria com seu dinheiro?" Pensar numa situação quando ela ainda não figura numa lista real de preocupações é muito diferente de ter que tomar uma decisão efetiva diante de um problema concreto, e as pesquisas, tal como são apresentadas, não dão conta dessa sutileza.
} 
Como ocorre com diversas outras formas de tentar prever o futuro, porém, as pesquisas de intenção de voto são frequentemente desmentidas pelas urnas. Isso não impede nem impedirá os gurus da política, em todos os lugares e todas as épocas, de continuar lucrando com previsões remuneradas. O sucesso das pitonisas eleitorais se deve justamente à natureza imprevisível do ramo em que se especializaram: afinal, se estivesse disponível uma ferramenta capaz de antever com absoluta precisão o resultado de uma eleição, todos os que dela se dotassem estariam em pé de igualdade, desempregando de imediato os especialistas em interpretação de pesquisas.

As pesquisas eleitorais convencionais guardam com as eleições uma característica em comum: captam uma escolha, sem captar as razões dessa escolha (ainda que se trate de escolhas distintas na forma de expressão). Quando um entrevistador pergunta em que candidato o eleitor pretende votar, não nos pergunta o porquê daquela decisão; da mesma forma, no ato de votar, o eleitor não precisa explicar as razões que o levaram a apertar a sequência de botões correspondente ao candidato escolhido.

A semelhança entre pesquisas e eleições, porém, termina aí. Simulando simular $\mathrm{o}$ ato de $\operatorname{votar}^{15}$, a pesquisa eleitoral vende a impressão de desvendar a distribuição real da preferência dos eleitores entre os diferentes candidatos naquele momento.

Pesquisas são realizadas em diferentes momentos ao longo de um ciclo eleitoral. É possível encontrar pesquisas divulgadas quase quatro anos antes de um pleito, mas o mais comum é que seu número cresça com a proximidade da data da eleição.

Seja quatro anos ou um dia antes do voto, porém, o objetivo da pesquisa é, em tese, o mesmo: discernir o resultado mais provável de uma eleição. Dizemos "em tese" porque, na prática, pesquisas servem a outros fins, dentre os quais, evidentemente, aquele de que trata a hipótese deste estudo, que é a influência da divulgação de seus resultados sobre o comportamento do eleitorado.

Isto nos traz de volta à proposição inicial deste capítulo. Numa pesquisa realizada um ano, ou mais, antes da próxima eleição presidencial, faz pouco sentido, em princípio, formular a pergunta "Se a eleição fosse hoje..." A rigor, se a intenção fosse de fato prever o resultado da eleição, seria justificável propor uma formulação alternativa: “Em 7 de outubro de 2018, em quem você votará (ou acha que votará) na eleição para

\footnotetext{
${ }^{15}$ Alguns levantamentos chegam ao requinte de providenciar uma falsa urna eletrônica, simulada em um aplicativo para tablet, onde o eleitor digita seu "voto" tal como supostamente o faria na cabine da seção eleitoral (DATAFOLHA, 2014).
} 
presidente da República?” Evidente que esta proposta de formulação é uma provocação, em nome do argumento que se quer expor. Afinal de contas, muitos eleitores não saberiam respondê-la, e nenhum eleitor de boa fé pensaria: "Hoje quero votar no candidato X., mas sei que no dia da eleição vou votar no candidato Y.” Teoricamente o que se deseja apurar é qual candidato teria mais chances de se eleger no dia da eleição. Mas nada garante tampouco que, para esse fim, a formulação "Se a eleição fosse hoje..." produza resultado mais preciso ou mais próximo da efetiva apuração final dos votos.

Os responsáveis pelas empresas de pesquisas costumam fazer a analogia da "fotografia" para definir seu trabalho. A pesquisa não passaria, portanto, de um registro de tendências de voto em um determinado momento de um ciclo eleitoral. Trata-se de uma analogia imprecisa, a menos que se leve em consideração que o ato de tirar (e divulgar) uma fotografia possa ter o poder de influenciar acontecimentos posteriores, do mesmo modo que na física quântica, em certas situações, a medição de um sistema afeta o estado desse mesmo sistema.

Essa imprecisão enseja a entrada em cena da suposta expertise dos "especialistas em comportamento eleitoral", que vendem aos meios de comunicação e a partidos políticos a capacidade de interpretar o "fotograma" e a partir dele prever o "final do filme", ou seja, o resultado da eleição. O prestígio desses especialistas aumenta na medida em que o acerto de suas previsões diverge da expectativa geral. Um exemplo foi proporcionado pelo cientista social Emmanuel Todd, na eleição presidencial francesa de 1995. Meses antes do pleito, quando o candidato Jacques Chirac estava em seu pior momento nas pesquisas, em terceiro lugar nas intenções de voto, Todd previu: "Os eleitores de Chirac ainda não sabem que vão votar nele" (FONTENELLE, 1995a; BACQUÉ e SAVEROT, 1995).

Por mais simples que pareça a decisão de votar neste ou naquele candidato, trata-se de uma decisão que leva em conta uma infinidade de fatores conscientes e inconscientes. O processo de decisão de voto é tema de diversos estudos acadêmicos (BERELSON et alii, 1954; FIORINA, 1976; FOURNIER et alii, 2004). Entre eles poderíamos citar o histórico pessoal desde o nascimento - o grupo social em que se foi criado e aquele em que se vive, a categoria profissional a que se pertence etc. - e opiniões idiossincráticas que não tem necessariamente a ver com considerações políticas em tese mais relevantes: a empatia despertada por determinado candidato, por exemplo.

O eleitor pode formar a convicção política que resulta em sua decisão de voto a partir de duas fontes: sua experiência pessoal - aqui entendida como a observação 
empírica dos acontecimentos políticos - e a informação que nos é proporcionada por intermédio dos relacionamentos sociais que travamos. Por razões práticas facilmente compreensíveis, a experiência pessoal sem filtros tem um peso muito pequeno em nossa decisão de voto. O tempo disponível e a possibilidade de acesso para adquirir informação política em primeira mão - por exemplo, comparecendo a comícios e outros encontros políticos, ou a sessões parlamentares - é necessariamente limitada. O grosso, portanto, da formação da opinião política provém da análise íntima de informações recebidas de outras pessoas - seja diretamente, daqueles que estão à nossa volta (parentes, amigos, colegas de trabalho) - ou indiretamente, pela mediação dos veículos de comunicação.

O grau de autonomia individual nessa tomada de decisão pode variar - em diversas sociedades contemporâneas, por exemplo, as relações de gênero estão constituídas de tal modo que a formação das decisões das mulheres está sujeita a uma série complexa de relações em que não são necessariamente representados aqueles que, em tese, seriam seus melhores interesses (BIROLI, 2016).

\subsection{Questões metodológicas das pesquisas}

O avanço no campo da estatística permitiu, desde a primeira metade do século $\mathrm{XX}$, que se pudesse conhecer de antemão, com razoável grau de aproximação, as intenções de voto de qualquer corpo eleitoral, sondando-se apenas uma pequena amostragem desse mesmo eleitorado. O princípio estatístico é conhecido como "amostragem probabilística": sorteando-se ao acaso um número suficientemente grande de indivíduos, de um universo cuja composição é conhecida, pode-se chegar a uma estimativa proporcional aproximada da composição desse universo. No caso da eleição presidencial brasileira, de um universo de 142,8 milhões de eleitores, seria possível estimar de forma aceitável as preferências dos eleitores com base em cerca de 2.000 entrevistas. A precisão dessa estimativa, ou o "intervalo de confiança", tende a aumentar quanto maior for o tamanho da amostra, ou seja, o número de entrevistados, sendo admitida uma "margem de erro", probabilidade, em geral de $5 \%$, de que os valores efetivos verificados no universo do qual se extraiu a amostra se revelem fora do intervalo de confiança. 
Há, porém, uma questão prática importante, para a qual os responsáveis pelas empresas de pesquisa raramente chamam a atenção (embora não a ignorem): da forma como são feitas as pesquisas eleitorais, não se pode falar em "amostragem probabilística”. A amostra não é puramente aleatória, pois seria preciso realizar o sorteio a partir de todo o universo de eleitores e fazer chegarem as perguntas a cada um dos sorteados, em milhares de municípios diferentes, o que tornaria impraticável tal pesquisa, por imperativos de custo e logística.

Para contornar esse óbice prático, e também com base nas leis da estatística, existe uma metodologia alternativa à amostragem probabilística, conhecida como "amostragem por quotas". Os pesquisadores dividem o universo de eleitores em "quotas", com base em critérios sociais e demográficos, buscando produzir resultado o mais próximo possível à amostragem probabilística. A seleção desses critérios - faixa etária, renda familiar, local de residência, grau de escolaridade - se baseia na experiência de pesquisas passadas e na disponibilidade de recenseamentos confiáveis que permitam essa divisão. Munidas (no caso brasileiro) de dados demográficos apurados pelo Instituto Brasileiro de Geografia e Estatística (IBGE) em seus diversos levantamentos, e buscando refinar esses dados com outros estudos, alguns de elaboração própria, as empresas de pesquisa chegam a uma repartição aceitável, para seus fins, da população em quotas, e é dentro dessas quotas que sorteiam seus entrevistados e realizam suas entrevistas, em um número de municípios muito menor que aquele exigido por uma amostragem puramente probabilística.

O primeiro problema metodológico que essa alteração provoca, para a análise das pesquisas, é que a divisão em quotas pode estar sujeita a erros, por parte daqueles que estabelecem seus critérios. O recenseamento do IBGE pode estar desatualizado, ou as categorias escolhidas para dividir a população em quotas podem não ser as mais adequadas para a questão estudada (a posse de um aparelho telefônico, por exemplo, não é mais um indicador de riqueza relevante). Isto obriga as empresas a constante avaliação e aperfeiçoamento de seus critérios.

Um segundo problema metodológico gerado pela abordagem das empresas de pesquisa é que, embora a amostragem por quotas seja metodologicamente diferente da amostragem probabilística, as empresas de pesquisa empregam (à falta de melhor solução) a terminologia desta última. Assim, um dos conceitos de maior emprego, o de 
"margem de erro", é indevidamente utilizado como evidência da precisão das pesquisas. Diferentes trabalhos acadêmicos, nas últimas décadas, apontam esse uso impróprio (KISH, 1965; CARVALHO e FERRAZ, 2006). Além, disso, a amostragem por quotas induz a outro efeito estatístico, conhecido como design effect: como os entrevistados são agrupados por áreas (por uma questão de economia de recursos), aumenta a probabilidade de que as respostas sejam similares umas às outras (SHACKMAN, 2001). Esse efeito pode ser corrigido empregando técnicas estatísticas, mas a falta de transparência na divulgação dos métodos utilizados torna impossível, na prática, verificar se tais efeitos são levados em conta no cálculo final das intenções de voto.

Não se está pondo em dúvida, aqui, a boa fé das empresas de pesquisa, nem se pretende dar curso a teorias conspiratórias que veem nas pesquisas de intenção de voto mera intenção de manipular o eleitor (embora seja possível encontrar, pontualmente, incongruências entre os números de diferentes empresas, o que dá margem a questionamentos válidos). O que se pode discutir é a pretensão da pesquisa eleitoral ao status de método científico.

Popper (1980), em seu clássico texto Conjecturas e Refutações, estabelece como critérios de cientificidade de uma teoria, entre outros:

\begin{abstract}
A teoria que não for refutada por qualquer acontecimento concebível não é científica. A irrefutabilidade não é uma virtude, como frequentemente se pensa, mas um vício. Todo teste genuíno de uma teoria é uma tentativa de refutá-la. A possibilidade de testar uma teoria implica igual possibilidade de demonstrar que é falsa. Há, porém, diferentes graus na capacidade de se testar uma teoria: algumas são mais "testáveis", mais expostas à refutação que outras; correm, por assim dizer, maiores riscos. (POPPER, 1980, p. 4)
\end{abstract}

Vistas sob a perspectiva de Popper $^{16}$, as pesquisas de intenção de voto não atendem o teste da refutabilidade, a não ser num único caso: quando são realizadas no próprio dia da eleição (as chamadas "bocas-de-urna") e confrontadas ao resultado desta. Afora essa situação, a única maneira de aferir a precisão de uma pesquisa, e em tese a da amostragem selecionada, é a comparação entre levantamentos de diferentes empresas. Ainda assim, resultados semelhantes entre empresas não comprovam

\footnotetext{
${ }^{16} \mathrm{O}$ influente trabalho de Popper foi criticado por outros autores. Kuhn $(1970$, p. 146) pondera que, se aplicados à risca os critérios de Popper, "todas as teorias teriam que ser rejeitadas a todo momento". A incompletude e a imperfeição da teoria seria uma característica intrínseca à "ciência normal".
} 
mutuamente a precisão científica de seus levantamentos; comprovam, no máximo, que a metodologia empregada por ambos é semelhante, sem que seja possível afirmar que é correta $^{17}$.

No caso das eleições brasileiras, as empresas são obrigadas a registrar, junto ao Tribunal Superior Eleitoral, os critérios adotados para a realização de pesquisas de intenção de voto. Em geral limitam-se a indicar, porém, a proporção entre as faixas etárias, as cidades e os bairros onde as entrevistas serão realizadas, e a íntegra do questionário aplicado. Essas informações não são suficientes para que se reproduza de forma independente a pesquisa, como tentativa de refutar, senão seus resultados, pelo menos sua metodologia.

Nos Estados Unidos, a irrefutabilidade das pesquisas de opinião em ciência política vem sendo discutida, sobretudo depois que um estudo publicado pela revista Science, em maio de 2015, se mostrou fraudulento, obrigando a revista a retratar-se. O autor do estudo, Michael LaCour, estudante da Universidade da Califórnia em Los Angeles, queria demonstrar a eficácia de campanhas em favor do casamento entre pessoas do mesmo sexo, mas, quando the foram solicitados os dados em que baseou suas conclusões, negou-se a fornecê-los. Embora o escândalo tenha ocorrido no meio acadêmico, levou Nate Cohn, colunista político especializado em estatística do New York Times, a estender o questionamento à área das pesquisas de opinião:

[M]esmo antes do caso LaCour, estava se tornando evidente que um grupo diferente de pesquisadores da opinião pública - institutos de opinião pública adere a níveis de transparência muito inferiores àqueles da ciência social acadêmica. Grande parte do mundo das pesquisas de opinião permanece abrigado do tipo de escrutínio que é necessário para identificar e deter práticas questionáveis. (...) No mundo das pesquisas de opinião, nenhum instituto de pesquisa divulga seus microdados de maneira oportuna. Quando os institutos chegam a divulgá-los - em geral meses após a publicação, num arquivo cujo acesso exige uma assinatura paga -, raramente fornecem as explicações metodológicas detalhadas necessárias para replicar os resultados das pesquisas. (COHN, 2015)

O panorama apresentado por Cohn se aplica ao caso latino-americano, como será abordado no Capítulo 2. Por mais que a legislação imponha às empresas de

\footnotetext{
${ }^{17}$ Existe ainda o herding (literalmente, "pastoreio"), conceito criado pelos especialistas para definir a tendência de algumas empresas a "corrigir" os resultados de suas pesquisas, antes da divulgação, e sobretudo às vésperas da eleição, para que eles não discrepem muito dos das concorrentes (LINZER, 2014). O termo é um recurso à metáfora do pastor que mantém o rebanho próximo.
} 
pesquisas restrições que visam a uma maior transparência, estas são insuficientes para permitir a replicação (ou não) dos resultados, ou seja, sua refutabilidade.

Sem citar Popper, Kish (1965), respeitado autor do campo da estatística, chegou por conta própria a uma conclusão parecida em relação à cientificidade das pesquisas por quotas, em seu livro Survey Sampling:

A amostragem por quotas não é um método científico definido. Em vez disso, cada uma delas parece ser uma produção artística, difícil de definir ou descrever (...). Além disso, previsões eleitorais muitas vezes falham, às vezes por amplas margens. Muitas delas são silenciosamente esquecidas. Umas poucas se tornam ruidosos escândalos; faz-se então a tentativa de livrar-se deles com explicações e desculpas ad hoc, que são ignoradas até o momento em que se tornam necessárias. (KISH, 1965, p. 565)

Não são apenas os estatísticos que encontram problemas na interpretação das pesquisas. No campo da sociologia, Bouza (1998, p. 49-50) apontou alguns "erros conceituais sobre as pesquisas em geral e sobre as pesquisas eleitorais em particular", que resumiu na seguinte lista de "confusões":

- Confusão entre níveis espaço-temporais de predição. A pesquisa se refere ao presente de sua realização, mas é usada para prognosticar o futuro. “As pesquisas nunca se equivocam sobre o futuro pela simples razão de que não falam do futuro. Equivocamse, equivocamo-nos, os sociólogos.”

- Confusão entre o caráter cambiante ou fixo da opinião pública e sobre o que constitui a superfície ou o fundo de nossas crenças. "Em uma situação confusa e cambiante (...) as mudanças na opinião podem ser significativas”, e nem sempre o analista leva isso em conta devidamente.

- Confusão entre o objetivo e o subjetivo na ciência, e sobre a ação do "clima da opinião". O sociólogo não está alheio ao "clima da opinião", que pode afetar sua capacidade de analisar os números sem subjetividade, como em tese exigiria o método científico.

- Erros sobre o conceito de "estimativa" frente ao "voto direto". Aqui Bouza trata da imprecisão na tentativa de estimar como será a distribuição do voto dos indecisos. "Uma estimativa é um risco assumido pelo sociólogo, mas não é um dado indiscutível. Tomá-lo como indiscutível leva a tomar decisões errôneas.” 
- Confusão sobre os efeitos da publicação de pesquisas. Estudos realizados sobretudo nos Estados Unidos detectaram a possível existência de um efeito bandwagon (os eleitores aderem ao candidato líder nas pesquisas) ou de um efeito underdog (os eleitores aderem ao candidato em desvantagem para impedir a vitória do candidato líder). "A mecânica de funcionamento desses e outros efeitos não é muito conhecida", reconhece Bouza.

- Confusão interpretativa entre "estrutura" e "gênese". A pesquisa nos permite enxergar a estrutura da opinião pública eleitoral, mas não nos permite conhecer sua gênese, que só pode ser investigada por meio de pesquisas qualitativas, entrevistas e análises cognitivas.

Os erros conceituais relacionados por Bouza apontam para a necessidade de aprofundamento da discussão a respeito do uso das pesquisas de opinião, não apenas pelo jornalismo, mas pelas ciências sociais. Por seu caráter intrinsecamente político, a pesquisa de intenção de voto está sujeita a influências que não podem ser ignoradas quando de seu uso e interpretação.

\subsection{Gallup, Ibope e as origens das pesquisas de opinião}

Pode-se retraçar à primeira metade do século XX o início do emprego das pesquisas de opinião em diversos setores da vida social, notadamente na medição de hábitos de consumo; da audiência dos meios de comunicação; e das tendências dos eleitores. Neste último aspecto ganharam fama mundial os esforços de George Gallup (1901-84), a partir de 1932, para prever os resultados das eleições presidenciais nos Estados Unidos.

Gallup defendia as pesquisas com argumentos tanto técnicos quanto ideológicos. No livro The Pulse of Democracy (1940), apresentava seu método de entrevistas junto à população como uma oportunidade para "o homem comum ter a liberdade de expressar suas necessidades básicas", em uma conjuntura mundial marcada pelo totalitarismo dos regimes nazistas, fascistas e comunistas (GALLUP, apud PETERS e SIMONSON, 2004, p. 130). 
O exemplo de Gallup espalhou-se previsivelmente a outros países, ensejando em 1942 o surgimento, no Brasil, do Instituto Brasileiro de Opinião Pública e Estatística (o Ibope). ${ }^{18}$ Em 27 de março de 1945, nos estertores do regime ditatorial do Estado Novo e diante da perspectiva da primeira eleição presidencial direta desde 1930, o Ibope divulgou aquilo que o Diário da Noite qualificou como "primeira pesquisa política" realizada pela empresa, como mencionado na introdução deste estudo.

Na construção de sua imagem como empresa de pesquisa, desde o início o Ibope valeu-se dos meios de comunicação. Empregando a definição de campo proposta por Bourdieu (1973), nosso pressuposto é que o campo das pesquisas de opinião, um subcampo das ciências sociais, construiu-se como tal em parte graças às relações que manteve com o campo do jornalismo.

As medições de audiência de rádio estão na raiz da notoriedade angariada pelo Ibope. O rádio era, então, o meio de comunicação de maior alcance no Brasil (a televisão comercial só viria a ser inaugurada em 1950 e ainda seria, por pelo menos uma década, um veículo elitista, em razão do custo de aquisição dos aparelhos). Em um mercado altamente competitivo, disputavam a audiência - e as verbas publicitárias - as rádios Nacional, Mayrink Veiga, Tupi, Continental e Globo, entre muitas outras.

Como era de esperar, os primeiros levantamentos de audiência de rádio causaram controvérsia. As rádios desfavorecidas pelos números dessas pesquisas se insurgiram contra seus resultados, como testemunham diversas referências em jornais da época. O trecho abaixo, de um crítico de rádio, é uma das referências mais antigas ao rebuliço que o Ibope provocou no meio do rádio:

\footnotetext{
Batendo em milhares de portas, de Cascadura ao Leblon, oferece-nos o Ibope um serviço de informações sobre as preferências dos ouvintes de rádio. (...) Fica-se sabendo da péssima aceitação de muito programinha enfatuado de granja, fica-se a par do desprezo gostoso que o público dispensa ao horário "privilegiado" de dengosos locutores de sorriso encomendado.

E sente-se então a força contaminante dos horários de novelas, a preferência às vezes surpreendente por certas horas e por certos programas não apreciados pela crítica e pelos críticos.
}

\footnotetext{
${ }^{18}$ Hoje em dia, em seu sítio na internet, o lbope ignora o papel de seu fundador, talvez por ter ele se tornado persona non grata junto aos publicitários paulistas ao atacá-los num artigo de 1955 na revista PN, preconceituosamente intitulado "Carcamanopeia". Cf. Abreu (2007, p. 247). Em entrevista ao Diário da Noite (26 mar. 1945, p. 1), Penteado afirma que as operações do Ibope em São Paulo tiveram início em maio de 1942.
} 
Há surpresas e surpresas no Ibope. Há desilusões também, e não poucas. É sobretudo um perfeito atestado de óbito em muita leviandade radiofônica. (DOMINGOS, 1944)

Contribuía para essa reação negativa o desconhecimento, pelo público, das técnicas estatísticas que permitiam a formação das amostras representativas e a realização de pesquisas (então chamadas frequentemente de "inquéritos", por influência do francês "enquête") razoavelmente precisas.

O fundador do Ibope, Auricélio Penteado, era formado em Direito. Ligado na juventude ao Partido Comunista - em 1936, chegou a ficar três meses preso em São Paulo (KAIREPOVS, 2003, p. 137) -, Penteado conheceu os métodos de Gallup depois de um estágio nos Estados Unidos, onde buscava elementos que permitissem conhecer a audiência da rádio Kosmos, da qual era diretor (DIEGUEZ, 2010). Com bons contatos no ramo da publicidade, de volta ao Brasil convenceu a associar-se a ele na empreitada o respeitado publicitário Cícero Leuenroth, fundador da agência Standard ${ }^{19}$. Ao longo dos anos seguintes, Penteado dedicou-se a uma série de entrevistas, palestras e artigos (sobretudo na revista Publicidade \& Negócios ${ }^{20}$ ) para explicar ao mercado seus métodos. ${ }^{21}$ Nesse sentido, é significativa a nota abaixo.

VAI FALAR O SR. AURICÉLIO - O sr. Auricélio Penteado, diretor do Ibope, vai realizar uma palestra na Associação Brasileira de Propaganda. Falará na certa sobre a sua estatística da opinião pública e da análise dos seus questionários. Como o debate é franco, é de bom momento para um confronto entre o sr. Auricélio Penteado e o pessoal dos "Associados". A "conferência" do sr. Auricélio está marcada para as 18 horas do dia 26, na ABP, no salão Belisário de Souza. (Diário Carioca, 26 abr. 1949, p. 7)

O pequeno texto condensa algumas informações relevantes. Em primeiro lugar, é significativo que a palestra se dê na Associação Brasileira de Propaganda - as agências de publicidade eram, como ainda são, as interessadas primordiais nas pesquisas de audiência na mídia, em razão do interesse em maximizar o número de

\footnotetext{
${ }^{19}$ Diário Oficial da União, 27 jan. 1945, seção 1, p. 74.

${ }^{20}$ Publicidade foi criada em 1940, no Rio de Janeiro, pelo jornalista catarinense Licurgo Costa (19042002). Em 1946 passou a chamar-se PN - Publicidade \& Negócios. Cf. Abreu (2007, p. 207-8).

${ }^{21}$ Entre outros artigos, foi possível localizar "Qual o número de receptores (de rádio) existentes no Brasil?" (out. 1944); "Resíduo de ouvintes, sombra, inércia e black-out" (ago. 1945); "Nova técnica do questionário 'quinta-mensional' (sic), do dr. Gallup" (set. 1947). Cf. Diário da Noite, 21 out. 1944, p. 7; 14 ago. 1945, p. $3 ; 1$ 을 set. 1947, p. 8.
} 
receptores dos anúncios que produziam. E a referência aos Diários Associados é fruto da controvérsia despertada pelo Ibope: a rede de jornais e rádios de Assis Chateaubriand questionara os resultados dos levantamentos do Ibope em relação à audiência das rádios "associadas", como a Tupi. ${ }^{22}$

A credibilidade das pesquisas eleitorais sofreu um abalo em 1948, quando George Gallup errou pela primeira vez seu prognóstico para a eleição presidencial dos Estados Unidos: previu a vitória do republicano Thomas Dewey e quem se elegeu foi o democrata Harry Truman. Penteado, mais uma vez, foi aos meios de comunicação explicar que "não houve erro técnico nesse prognóstico, nem constituem as pesquisas de opinião pública um processo falho"23. Já então (como ainda hoje ocorre a cada eleição) a volatilidade do eleitorado foi responsabilizada pela diferença entre os números das pesquisas e o resultado das urnas. Ressalte-se, como reiteração do caráter "científico" das pesquisas, a analogia entre estas e a estreptomicina - primeiro antibiótico eficaz contra a tuberculose e grande novidade da medicina de então:

O erro de Gallup, disse ele [Penteado] referindo-se ao principal desses pesquisadores, foi o de não haver admitido expressamente nos seus comentários a possibilidade de uma mudança à última hora, advertindo seu público de que os prognósticos eleitorais publicados em pesquisas de opinião pública estão sujeitos a esses azares. (...) “Atacar George Gallup e o admirável grupo de pesquisadores que se dedicam à demoscopia ${ }^{24}$ é injustiça das mais clamorosas, pois eles pouco têm pedido em troca de seus magníficos esforços em prol do desenvolvimento dessa nova ciência (...) É como se condenássemos a estreptomicina por um só caso de aplicação infeliz.” (O Globo, 8 nov. 1948, p. 9)

Duas décadas depois, o Ibope já fora promovido a manchete de primeira página, como mostra a leitura da Última Hora de 4 de outubro de 1965, cujo título era "Ibope anuncia: Negrão venceu", em referência ao triunfo de Negrão de Lima na eleição da véspera para o governo da Guanabara. Num tempo em que a apuração dos resultados

\footnotetext{
${ }^{22} \mathrm{~A}$ celeuma entre o Ibope e os Diários Associados duraria anos. É mencionada, por exemplo, por Barbosa (1949).

${ }^{23}$ O Globo, 8 nov. 1948, p. 9.

${ }^{24}$ Termo que não vingou na língua portuguesa, proposto para definir os estudos de comportamento da população baseados em pesquisas por amostragem, "demoscopia" tem uso corrente na língua espanhola.
} 
podia levar dias, ou até semanas, o diário carioca recorria a uma empresa de pesquisas para antecipar a seus leitores o anúncio da vitória do candidato que apoiava.

De lá para cá, o Ibope consolidou sua influência, tornou-se sinônimo dicionarizado de "audiência" e "prestígio" ("Fulano está bem no ibope") e, sete décadas depois, ainda é líder do setor no Brasil. Quase diariamente, nas pautas da imprensa, se veem levantamentos, do próprio Ibope ou de outras empresas de pesquisas, usados como embasamento para as mais variadas argumentações.

\subsection{O discurso científico das pesquisas}

Nas entrevistas e artigos dos responsáveis pelas empresas de pesquisas de opinião pública analisados preliminarmente para este estudo, chama a atenção a aparente humildade com que todos tratam da precisão das pesquisas de intenção de voto. Não se deve tomar seus resultados como infalíveis, explicam: uma pesquisa é uma "fotografia", um instantâneo de um momento fugaz de uma opinião pública em constante mutação. Em entrevista concedida durante a campanha das eleições municipais de 2012, Márcia Cavallari, diretora do Ibope (Instituto Brasileiro de Opinião Pública e Estatística), recorreu a essa metáfora:

Cada vez mais as pesquisas têm de ser interpretadas como diagnóstico do momento. São uma fotografia do momento. A sequência dessas fotografias vai montando um filme, com as tendências. (Congresso em Foco, 14 out. 2012)

Apesar do discurso de sua diretora em 2012, a página do Ibope na internet continuava em 2015 a usar o discurso da precisão científica para promover a qualidade de seu trabalho.

As pesquisas políticas foram implantadas no Brasil pelo Ibope, na década de 50 (sic). Atualmente, o Ibope é a única empresa de pesquisa que realiza pesquisas eleitorais em todos os estados da federação. Em um único turno, a empresa chega a realizar mais de 140 sondagens e treina mais de 1.300 entrevistadores. Com um índice de acerto das candidaturas que oscila de $97 \%$ a $100 \%$, o Ibope confirma a cada eleição a contribuição dada pelas pesquisas à democracia brasileira. Sem elas, não se poderia ter detectado o impacto que a discussão do aborto causou nas eleições presidenciais de 2010, por exemplo. (IBOPE, 2015). 
O objetivo de uma pesquisa eleitoral, em tese, é aferir as preferências do eleitorado. Elas acabam, porém, por influenciar o comportamento desse mesmo eleitorado, que, ao acreditar em seus resultados, pode ser levado a alterar sua decisão de voto. Inúmeros acadêmicos estudaram essa influência (THIOLLENT, 1989; TRAUGOTT e LAVRAKAS, 2008). Independentemente de acreditar ou não nos números das pesquisas, somente no dia da eleição é possível confrontar seus resultados com a realidade, pelo simples fato de haver, a cada turno eleitoral, uma única consulta oficial ao universo dos votantes. No entanto, até desse único confronto se escusam os responsáveis pelas empresas de pesquisas, ao afirmar que o eleitorado é tão volátil que mesmo uma pesquisa realizada no próprio dia da eleição (a chamada "boca-de-urna") só tira uma "fotografia", ainda sujeita a mudanças.

Trata-se de um discurso que exime de toda refutabilidade as pesquisas. $\mathrm{O}$ discurso dos responsáveis pelas empresas se caracteriza por um jogo duplo: ao mesmo tempo em que apregoam sua precisão científica quando se trata da promoção junto a potenciais clientes, eles se resguardam diante da sociedade da sujeição à refutabilidade da única pesquisa que pode ser confrontada à realidade, a "boca-de-urna".

Essas considerações não parecem figurar entre as preocupações dos analistas políticos dos veículos de comunicação de maior alcance, que recorrem constantemente à alegada precisão científica das pesquisas eleitorais para embasar seus comentários. A título de exemplo histórico, extraímos o caso abaixo da Folha de S. Paulo durante os primeiros meses da campanha eleitoral de 1989, ano da primeira eleição presidencial no Brasil após a ditadura militar de 1964-85. O articulista se baseia numa pesquisa do Datafolha onde Orestes Quércia despontava como um dos preferidos da opinião pública, a pouco mais de seis meses do pleito:

\footnotetext{
Desde que começou a novela em torno da hipótese da candidatura Orestes Quércia à Presidência da República, o secretário de Governo de São Paulo e operador político do governador paulista, Roberto Rollemberg, repete sempre que só um "fato novo" faria Quércia sair candidato. A pesquisa que a Folha publica hoje pode ser esse fato novo. Ela dá consistência científica e numérica à percepção do mundo político ou, ao menos, dos peemedebistas, de que só Quércia é capaz de enfrentar Brizola, Lula e, agora, Fernando Collor de Mello com chances de vencer. ${ }^{25}$ (ROSSI, 1989)
}

\footnotetext{
${ }^{25}$ Registre-se que Quércia não se deixou convencer pela "consistência científica" que o favorecia, pois decidiu não se candidatar em 1989. Veio a fazê-lo em 1994, ficando em quarto lugar, com $4 \%$ dos votos válidos.
} 
Note-se o recurso à credibilidade da ciência ("consistência científica e numérica") para legitimar uma interpretação das preferências da opinião pública embora o mesmo texto, no parágrafo seguinte, reconheça que se trata de um dado "muito preliminar" e que 58\% dos entrevistados, na mesma pesquisa, não haviam apontado nenhum nome espontaneamente. O texto de Rossi é apenas um exemplo, e de 1989 para cá não cessaram as análises políticas inspiradas em números de pesquisas, com raros questionamentos em relação à validade desses levantamentos.

Enxergamos nessa necessidade de legitimação aquilo que Habermas define, em "Ciência e Tecnologia como "Ideologia", como "ação racional-teleológica". O autor sustenta que na sociedade industrial desenvolvida, em contraste com a "sociedade tradicional", a ciência e a tecnologia funcionam como a "ideologia" de legitimação do poder, substituindo a visão de mundo cosmológica que anteriormente era o fundamento legitimador. Ele estabelece uma distinção entre sistemas sociais baseados na interação simbólica e aqueles baseados na ação racional-teleológica, ou seja, a ação instrumental guiada por regras técnicas, baseadas no conhecimento empírico, correto ou não.

\footnotetext{
Tendo se tornado frágeis, as legitimações existentes são substituídas por novas. Estas últimas emergem da crítica do dogmatismo das interpretações tradicionais do mundo e reivindicam um caráter científico. No entanto, retêm funções legitimadoras, mantendo dessa forma relações de poder reais inacessíveis à análise e à consciência pública. (HABERMAS, 1989, p. 249)
}

Habermas prossegue sua argumentação afirmando que no regime capitalista regulado pelo Estado a ação do governo visa à obtenção da lealdade das massas por meio de intervenções que, garantindo certa segurança social, previnem reações contra o sistema. A política e o mecanismo das eleições gerais, vistos sob essa perspectiva, são, para Habermas, elementos que ajudam a assegurar a dominação política. Aplicando essa perspectiva à questão em discussão neste estudo, pode-se interpretar o uso das pesquisas eleitorais, e sua apregoada cientificidade, como forma de limitar as opções da sociedade a determinadas correntes e candidatos; e seu uso pelos analistas políticos como uma maneira confortável de dar caução científica a suas análises, quando elas exigiriam maior investigação, por meio de pesquisas qualitativas, entrevistas aprofundadas ou outros meios que permitissem enxergar, para além dos números de uma pesquisa quantitativa, as motivações profundas de cada eleitor ou grupo de eleitores. 
Habermas chega a fazer referência, em seu texto, ao processo eleitoral como parte desse sistema de legitimação, entendendo que são colocadas diante do eleitor opções limitadas e periódicas que, ao mesmo tempo em que criam uma aparência de democracia, garantem a continuidade do próprio sistema. "[A] propaganda pode fazer referência ao papel da tecnologia e da ciência de modo a explicar e legitimar por que, nas sociedades modernas, o processo de tomada de decisões democráticas em relação a problemas práticos perde sua função e 'precisa' ser substituído por decisões plebiscitárias em relação a conjuntos alternativos de líderes de pessoal administrativo" (HABERMAS, 1989, p. 253). Uma perversidade desse sistema é o fato de que nele "a comunicação é tão distorcida e restrita que as legitimações que funcionam como um véu ideológico não podem ser questionadas" (p. 257). Ao “informarem" ao eleitor as alternativas entre as quais ele terá que fazer sua escolha, as pesquisas eleitorais, apresentadas como científicas e isentas de refutação, assim como as análises que delas fazem os comentaristas políticos por intermédio dos meios de comunicação, se inserem no processo de legitimação dessa ideologia conformista.

No próximo capítulo, examinaremos aspectos jurídicos da divulgação das pesquisas eleitorais. A percepção de que elas podem ter influência sobre o comportamento do eleitorado, abrindo caminho para manipulações se executadas ou divulgadas com má-fé, levou praticamente todos os países do mundo a adotar algum tipo de regulamentação para sua realização e publicação, sobretudo nos períodos de campanha eleitoral. Vamos nos debruçar especificamente sobre a legislação de dezoito países latino-americanos, entre eles os dois que são o objeto desta pesquisa, Brasil e Argentina. 


\section{2. $O$ controle das pesquisas eleitorais}

\subsection{Considerações históricas}

A consolidação das pesquisas eleitorais como elemento do debate político nos países da América Latina foi influenciada pela instabilidade política que marcou a região ao longo do século XX, com alternância entre períodos ditatoriais e outros, de eleições livres. Em muitos países, o retorno à democracia é relativamente recente. Podemos citar, entre outros, os casos de Equador (1979), Bolívia (1982), Argentina (1983), El Salvador (1984), Brasil e Uruguai (1985) e Chile (1989). Embora alguns desses países tenham realizado eleições sob regimes autoritários, esses pleitos não podiam ser considerados livres. Isso teve um inevitável reflexo sobre a importância que era atribuída às pesquisas eleitorais em cada nação e em cada período.

Pode-se afirmar que nas últimas décadas, com algumas exceções, e apesar de recuos recentes, a América Latina viveu um período de estabilidade democrática de extensão sem precedentes. $\mathrm{O}$ mercado de pesquisas eleitorais floresceu, despertando na maioria dos países da região a discussão sobre sua influência no comportamento do eleitor. Esse debate deu origem a diferentes iniciativas legislativas. Aqui examinamos 17 países de língua espanhola das Américas e um de língua portuguesa, o Brasil.

\subsection{A influência das pesquisas}

Ao escolher um candidato, o eleitor pode levar em conta uma série de fatores. A probabilidade de vitória é um desses possíveis fatores. $\mathrm{O}$ eleitor pode levar em conta as pesquisas de variadas maneiras. Uma delas foi descrita na literatura sobre o tema como bandwagon effect, ou, para empregar um termo já existente na língua portuguesa, do efeito de manada - a tendência a votar no candidato favorito para não "desperdiçar o voto". Outra, de certa forma inversa, foi batizada de underdog effect, literalmente "efeito azarão" - a tendência a votar no candidato com maiores probabilidades de derrotar o favorito ${ }^{26}$. Um terceiro efeito apontado pelos estudiosos é o "efeito motivacional" - ou seja, os números das pesquisas podem levar parte do eleitorado a

\footnotetext{
${ }^{26}$ SIMON (1954).
} 
desistir de comparecer às urnas, seja por considerar que seu candidato não tem chances, seja por considerar que a eleição está decidida, até mesmo em favor de seu escolhido. ${ }^{27}$

Em um sistema eleitoral de dois turnos, em que o primeiro turno habilita os dois primeiros colocados à disputa do segundo, verifica-se muitas vezes uma tendência à concentração da preferência do eleitor entre três nomes, dentre os quais sairão os dois "finalistas". Em sistemas de turno único, a tendência é da concentração da preferência entre dois nomes, numa espécie de segundo turno "antecipado". Nada impede o eleitor de optar, para "marcar posição", por um candidato que as pesquisas apresentam como desprovido de probabilidade de vitória. Também são inúmeros os casos de eleições em que um candidato dado como derrotado conseguiu contrariar os prognósticos e vencer, ou se habilitar para o segundo turno. Mas números desfavoráveis nas pesquisas tenderiam a ser um fator de desestímulo para os potenciais eleitores de um determinado candidato.

Além disso, não é incomum que as pesquisas "errem" - ou seja, prognostiquem um resultado eleitoral que não se verifica, por fim, no dia da eleição. Resultados fora da "margem de erro" anunciada pelas empresas de pesquisas se repetem em diversas eleições, em inúmeros países. Os responsáveis pelas pesquisas costumam atribuí-las não a erros de amostragem ou metodologia, e sim à volatilidade do eleitorado. Ressaltam, como visto acima, que a pesquisa representa uma "fotografia" 28 , e que cada vez mais os eleitores tomam sua decisão de voto apenas nos últimos dias que antecedem o pleito.

\subsection{Restrições à realização e divulgação de pesquisas}

A percepção de que as pesquisas são imprecisas tem levado vários países a discutir ou adotar restrições à sua realização e divulgação. Tais restrições se traduzem das seguintes formas:

\footnotetext{
${ }^{27}$ ANDERSEN e JENSEN (2014); TAYLOR e YILDIRIM (2010).

${ }^{28}$ Trata-se de uma metáfora conveniente para os responsáveis pelas pesquisas, pois ao mesmo tempo que as associa à precisão do registro fotográfico, exime-as de refutabilidade em razão de seu caráter fugaz. Não por acaso é recorrente no discurso desses responsáveis, em vários dos países pesquisados.
} 
- Restrições temporais à realização ou divulgação de pesquisas - em geral, sua interdição fora do período oficial de campanha, nos dias imediatamente anteriores à eleição ou no próprio dia do pleito (a chamada "boca-de-urna").

- Restrições quanto à forma de divulgação das pesquisas, impondo-se o registro oficial de informações como a data de realização das entrevistas, o método de elaboração da amostra e a íntegra do questionário submetido aos entrevistados;

- Restrição ao número de empresas autorizadas a realizar esses levantamentos, por meio de cadastro junto ao organismo responsável pela organização do pleito;

As primeiras tentativas de legislar sobre o assunto se concentravam no primeiro item acima, diante da percepção de que pesquisas tendenciosas poderiam ter um efeito indevido sobre a decisão de voto nos últimos de uma campanha. Hoje em dia, porém, revela-se impraticável coibir totalmente a divulgação do resultado de pesquisas dentro de qualquer Estado nacional, uma vez que os órgãos de imprensa de países vizinhos não estavam sujeitos à mesma restrição. Assim, por exemplo, na eleição presidencial francesa de 1995, embora a lei nacional proibisse a divulgação de pesquisas na semana que antecedia a votação, quem tivesse acesso aos jornais da Suíça (ou de outros países vizinhos), livremente vendidos em território francês, conheceria sem dificuldade quais os números apurados pelas diferentes empresas de pesquisa. ${ }^{29} \mathrm{O}$ advento da internet e a disseminação das redes sociais tornaram ainda mais fácil o acesso a informações publicadas fora das fronteiras nacionais, solapando qualquer tentativa de impedir que as pesquisas venham a ter influência sobre o eleitorado. Os críticos desse tipo de restrição apontam, além do argumento da inutilidade, outro de ordem informacional: o risco de criar um descompasso entre os eleitores com acesso aos números das pesquisas e aqueles sem acesso, gerando uma desigualdade de informação indesejável numa democracia, onde, em princípio, qualquer dado que possa influenciar a decisão de voto deve estar à disposição de todos os cidadãos.

Como nem sempre, porém, a legislação acompanha a velocidade das transformações tecnológicas, diversos os países ainda restringem a divulgação de pesquisas nos dias finais de campanha - o que é conhecido como blackout. Foi o caso,

\footnotetext{
${ }^{29}$ FONTENELLE (1995).
} 
por exemplo, da Argentina na recente eleição presidencial de 2015, em que foi vedada a publicação de sondagens nos oito dias que precediam a votação.

\subsection{Leis, acórdãos e regulamentos na América Latina}

Um exame da legislação e dos regulamentos eleitorais, no que se refere às pesquisas de opinião, mostra que a maioria dos países da América Latina caminhou no sentido da adoção de algum tipo de controle sobre sua realização e divulgação. Em quase todos os países pesquisados, é o código eleitoral que trata do tema; questões mais específicas, como o método de registro de pesquisas e de empresas de pesquisas, e o tipo de informação técnica que deve ser fornecida, são deixadas para acórdãos, resoluções e regulamentos elaborados pelos órgãos da Justiça eleitoral. No Brasil, desde 2004, à falta de regulamentação por iniciativa do Poder Legislativo, o Tribunal Superior Eleitoral vem publicando resoluções que aperfeiçoam as exigências relativas às pesquisas. $^{30}$ A Tabela 1, a seguir, detalha quais são os documentos legais que disciplinam essa matéria em cada um dos dezoito países pesquisados.

${ }^{30}$ DUARTE (2009, p. 21). 
Tabela 1. Legislação referente a pesquisas eleitorais nos países da América Latina

\begin{tabular}{|c|c|c|}
\hline País & Lei eleitoral (ano) & $\begin{array}{l}\text { Regulamento específico } \\
\text { que trata de pesquisas (ano) }\end{array}$ \\
\hline Argentina & Código Eleitoral Nacional (2002) & $\begin{array}{l}\text { Acórdão da Câmara } \\
\text { Nacional Eleitoral (2010) }\end{array}$ \\
\hline Bolívia & Lei do Regime Eleitoral (2010) & \\
\hline Brasil & $\begin{array}{l}\text { Lei das Eleições (1997, alterada em } \\
2006,2009,2013 \text { e 2015) }\end{array}$ & $\begin{array}{l}\text { Resolução do Tribunal } \\
\text { Superior Eleitoral (2013) }\end{array}$ \\
\hline Chile & $\begin{array}{l}\text { Lei Orgânica Constitucional } \\
\text { sobre Votações Populares } \\
\text { e Escrutínios (1988) }\end{array}$ & \\
\hline Colômbia & Lei 130 (1994) & $\begin{array}{l}\text { Resolução do Conselho } \\
\text { Nacional Eleitoral (1996) }\end{array}$ \\
\hline Costa Rica & Código Eleitoral (2001) & $\begin{array}{l}\text { Regulamento do Tribunal } \\
\text { Supremo de Eleições (1997) }\end{array}$ \\
\hline El Salvador & Código Eleitoral (2013) & \\
\hline Equador & Lei Orgânica Eleitoral (2009) & \\
\hline Guatemala & $\begin{array}{l}\text { Lei Eleitoral e de Partidos } \\
\text { Políticos (1985) }\end{array}$ & \\
\hline Honduras & Lei Eleitoral (2004) & $\begin{array}{l}\text { Acórdão do Tribunal } \\
\text { Supremo Eleitoral (2013) }\end{array}$ \\
\hline México & $\begin{array}{l}\text { Código Federal de Instituições } \\
\text { e Procedimentos Eleitorais (2008) }\end{array}$ & $\begin{array}{l}\text { Acórdão do Conselho } \\
\text { Geral do Instituto } \\
\text { Nacional Eleitoral (2014) }\end{array}$ \\
\hline Nicarágua & Lei Eleitoral (2000) & \\
\hline Panamá & Código Eleitoral (1997) & \\
\hline Paraguai & Código Eleitoral Paraguaio (1996) & \\
\hline Peru & Lei Orgânica de Eleições (2005) & $\begin{array}{l}\text { Resolução do Juízo } \\
\text { Nacional de Eleições (2010) }\end{array}$ \\
\hline $\begin{array}{l}\text { República } \\
\text { Dominicana }\end{array}$ & Lei Eleitoral (1997) & \\
\hline Uruguai & $\begin{array}{l}\text { Lei de Eleições (1925, alterada em } \\
\text { 1999); Lei dos Partidos Políticos } \\
\text { (1998) }\end{array}$ & \\
\hline Venezuela & $\begin{array}{l}\text { Lei Orgânica do Poder Eleitoral } \\
\text { (2002); Lei Orgânica dos } \\
\text { Processos Eleitorais (2009) }\end{array}$ & $\begin{array}{l}\text { Resolução do Conselho } \\
\text { Nacional Eleitoral (2013) }\end{array}$ \\
\hline
\end{tabular}

Fonte: Elaboração própria a partir da legislação de cada país.

Com base nos tipos de restrição mencionados mais acima, resumimos na Tabela 2 a situação atual em cada um dos países pesquisados quanto a cada um desses tipos. 
Tabela 2. Mecanismos de controle das pesquisas nos países da América Latina

\begin{tabular}{|c|c|c|c|c|}
\hline País & $\begin{array}{c}\text { Exigência de } \\
\text { registro das } \\
\text { empresas de } \\
\text { pesquisa }\end{array}$ & $\begin{array}{l}\text { Obrigação de } \\
\text { divulgação de } \\
\text { informações } \\
\text { técnicas }\end{array}$ & $\begin{array}{c}\text { Restrição } \\
\text { temporal a } \\
\text { pesquisas } \\
\text { durante a } \\
\text { campanha }\end{array}$ & $\begin{array}{c}\text { Restrição à } \\
\text { divulgação da } \\
\text { "boca-de-urna" }\end{array}$ \\
\hline Argentina & $\sqrt{ }$ & $\sqrt{ }$ & $\sqrt{ }$ & $\sqrt{ }$ \\
\hline Bolívia & $\sqrt{ }$ & $\sqrt{ }$ & $\sqrt{ }$ & $\sqrt{ }$ \\
\hline Brasil & $\sqrt{ }$ & $\sqrt{ }$ & & $\sqrt{ }$ \\
\hline \multicolumn{5}{|l|}{ Chile } \\
\hline Colômbia & $\sqrt{ }$ & $\sqrt{ }$ & & $\sqrt{1}$ \\
\hline Costa Rica & $\sqrt{ }$ & $\sqrt{ }$ & $\sqrt{ }$ & $\sqrt{ }$ \\
\hline El Salvador & & & $\sqrt{ }$ & $\sqrt{ }$ \\
\hline Equador & $\sqrt{ }$ & $\sqrt{ }$ & $\sqrt{ }$ & $\sqrt{ }$ \\
\hline Guatemala & & & $\sqrt{ }$ & $\sqrt{ }$ \\
\hline Honduras & $\sqrt{ }$ & $\sqrt{ }$ & $\sqrt{ }$ & $\sqrt{ }$ \\
\hline México & $\sqrt{ }$ & $\sqrt{ }$ & $\sqrt{ }$ & $\sqrt{ }$ \\
\hline \multicolumn{5}{|l|}{ Nicarágua } \\
\hline Panamá & $\sqrt{ }$ & $\sqrt{ }$ & $\sqrt{ }$ & $\sqrt{ }$ \\
\hline Paraguai & & $\sqrt{ }$ & $\sqrt{ }$ & $\sqrt{ }$ \\
\hline Peru & $\sqrt{ }$ & $\sqrt{ }$ & & \\
\hline Rep.Dominicana & & & & $\sqrt{ }$ \\
\hline Uruguai & & & & $\sqrt{ }$ \\
\hline Venezuela & & & $\sqrt{ }$ & $\sqrt{ }$ \\
\hline TOTAL (18) & 10 & 11 & 11 & 15 \\
\hline
\end{tabular}

Fonte: Legislação eleitoral dos respectivos países.

A partir do quadro acima podemos dividir os países da região em três subtipos, conforme o grau de controle sobre a realização e divulgação de pesquisas, apresentados na Tabela 3:

- Alto grau de controle, naqueles países onde se encontram reunidas pelo menos três condições: exigência de registro das empresas de pesquisa; obrigação de divulgação de informações técnicas; e algum tipo de restrição temporal à publicação de pesquisas durante a campanha, ainda que apenas no dia da eleição (boca-de-urna).

- Médio de grau de controle, naqueles onde apenas parte dos critérios acima é atendida; por exemplo, países onde o registro das empresas de pesquisa não é obrigatório, mas é preciso publicar as informações técnicas relativas aos levantamentos; ou onde existe apenas a restrição temporal no período próximo à votação.

- Baixo grau de controle, onde não há praticamente nenhum mecanismo formal de restrição, a não ser, em alguns casos, a proibição da publicação de pesquisas de "boca-de-urna", imperando a liberdade absoluta de realização e divulgação de pesquisas sem exigências quanto ao registro ou à publicação de dados técnicos e metodológicos. 
A maioria dos países pesquisados se encontra no grupo de "alto grau de controle", cujas principais características são a criação de um cadastro de empresas habilitadas a realizar pesquisas e a obrigatoriedade de divulgar determinados dados sobre a técnica e a metodologia empregadas. Mais adiante veremos em maior detalhe as variações, de um país para outro, no tipo de informação solicitada.

Tabela 3. Países da América Latina segundo o grau de controle da realização e divulgação de pesquisas

\begin{tabular}{|l|l|l|}
\hline $\begin{array}{l}\text { Alto grau de controle } \\
\text { (9 países) }\end{array}$ & $\begin{array}{l}\text { Exigência de registro das } \\
\text { empresas de pesquisa, } \\
\text { obrigação de divulgação de } \\
\text { informações técnicas e algum } \\
\text { tipo de restrição temporal a } \\
\text { pesquisas durante a } \\
\text { campanha }\end{array}$ & $\begin{array}{l}\text { Argentina, Bolívia, Brasil, } \\
\text { Colômbia, Costa Rica, } \\
\text { Equador, Honduras, México, } \\
\text { Panamá }\end{array}$ \\
\hline $\begin{array}{l}\text { Médio grau de controle } \\
\text { (5 países) }\end{array}$ & $\begin{array}{l}\text { Pelo menos um dos } \\
\text { seguintes mecanismos: } \\
\text { exigência de registro das } \\
\text { empresas de pesquisa, } \\
\text { obrigação de divulgação de } \\
\text { informações técnicas ou } \\
\text { algum tipo de restrição } \\
\text { temporal a pesquisas durante } \\
\text { a campanha }\end{array}$ & $\begin{array}{l}\text { El Salvador, Guatemala, } \\
\text { Paraguai, Peru, Venezuela }\end{array}$ \\
\hline $\begin{array}{l}\text { Pouco ou nenhum controle } \\
\text { (4 países) }\end{array}$ & $\begin{array}{l}\text { Pouca ou nenhuma restrição } \\
\text { formal à realização ou } \\
\text { divulgação de pesquisas }\end{array}$ & $\begin{array}{l}\text { Chile, Nicarágua, República } \\
\text { Dominicana, Uruguai }\end{array}$ \\
\hline
\end{tabular}

Fonte: Elaboração própria.

O período de blackout (ou veda, em espanhol) foi naturalmente a primeira reação dos legisladores à percepção de uma influência das pesquisas sobre o comportamento dos eleitores. No Brasil, a primeira regulamentação do gênero apareceu no Código Eleitoral de 1965, que proibia a divulgação de "resultados de prévias e testes pré-eleitorais" nos 15 dias anteriores ao pleito. ${ }^{31}$ A restrição mais comum diz respeito à divulgação de pesquisas em data próxima à da votação. Como mostra a Tabela 2, 11 dos 18 países pesquisados impõem esse tipo de restrição, e outros três proíbem, no dia do pleito, a "boca-de-urna", ou sua divulgação até o horário de fechamento das urnas ou da apuração dos votos. ${ }^{32}$ Os períodos de veda mais longos são os de Paraguai e El

\footnotetext{
${ }^{31}$ DUARTE (2009, p. 17).

32 Na República Dominicana essa proibição não é objeto de lei específica, mas o artigo 122 da Lei Eleitoral de 1997, que trata do sigilo do voto, proíbe a terceiros "averiguar por quais candidatos ou em que sentido" o eleitor votou, o que é interpretado como uma proibição às pesquisas no dia da eleição.
} 
Salvador, 15 dias, e os mais curtos, os de Brasil e Colômbia (apenas no dia da eleição). Dentre os países pesquisados que têm algum tipo de restrição temporal, apenas o Brasil e a Venezuela não o fazem por lei, e sim por resoluções da Justiça eleitoral.

No Brasil, o período de blackout variou enormemente ao longo dos anos. Em 1986, foi fixado em 21 dias; para as eleições municipais de 1988, foi ampliado a 30 dias; na eleição presidencial do ano seguinte, foi de 30 dias no primeiro turno e de dez dias no segundo. Nestas duas últimas eleições, veículos de comunicação foram à Justiça reivindicar o direito de divulgar as pesquisas, em nome do direito à informação e à liberdade de expressão, tendo obtido ganho de causa. ${ }^{33}$ Em maio de 2006, chegou a ser sancionada uma lei estabelecendo um blackout de 15 dias, mas em setembro do mesmo ano esse artigo específico foi derrubado pelo Supremo Tribunal Federal, em Ação Direta de Inconstitucionalidade requerida pelo Partido Social Cristão. O STF considerou que o texto violava o "direito à informação livre e plural como valor indissociável da idéia de democracia”. Desde então, as propostas de reestabelecimento de algum tipo de blackout têm esbarrado no argumento da liberdade de expressão.

Tabela 4. Restrição temporal à divulgação de pesquisas nos países da América Latina

\begin{tabular}{|l|l|}
\hline Argentina & Nos 8 dias anteriores à eleição (Lei, art. 44) \\
\hline Bolívia & A partir da segunda-feira anterior à eleição (Lei, art. 130) \\
\hline Brasil & No dia da eleição, até o fechamento das urnas (Resolução, art. 13) \\
\hline Chile & Não há \\
\hline Colômbia & No dia da eleição (Lei, art. 30) \\
\hline Costa Rica & Nos 3 dias anteriores à eleição (Lei, art. 138) \\
\hline El Salvador & Nos 15 dias anteriores à eleição (Lei, art. 176) \\
\hline Equador & Nos 10 dias anteriores à eleição (Lei, art. 302) \\
\hline Guatemala & Nos 3 dias anteriores à eleição (Lei, art. 223) \\
\hline Honduras & Nos 5 dias anteriores à eleição (Lei, art.149) \\
\hline México & Nos 3 dias anteriores à eleção (Lei, art. 237) \\
\hline Nicarágua & Não há \\
\hline Panamá & Nos 10 dias anteriores à eleição (Lei, art. 215) \\
\hline Paraguai & Nos 15 dias anteriores à eleção (Lei, art. 305) \\
\hline Peru & A partir da segunda-feira anterior à eleição (Lei, art. 191) \\
\hline República Dominicana & Proibida a realização da boca-de-urna (Lei, art. 122) \\
\hline Uruguai & No dia da eleição, até o fechamento das urnas (Lei, art. 60) \\
\hline Venezuela & Nos 7 dias anteriores à eleição (Resolução, art. 215) \\
\hline Fonte: Legislações eleitorais. &
\end{tabular}

${ }^{33}$ DUARTE (2009, p. 17-8). 
A necessidade de publicar informações técnicas sobre as pesquisas é uma evolução posterior na legislação. No Brasil, surge na legislação em 1986, quando a Lei 7.508 obriga as empresas de pesquisas a "colocar à disposição de todos os partidos, com candidatos registrados para o pleito, os resultados obtidos e publicados, bem como informações sobre os métodos utilizados e as fontes financiadoras dos respectivos trabalhos". ${ }^{34}$

Não existe um consenso, a julgar pelas diferenças legislativas entre os países pesquisados, em relação àquelas informações mais relevantes para assegurar que as pesquisas sejam realizadas dentro de parâmetros técnicos considerados adequados, conforme os critérios da estatística e das ciências sociais, e sejam divulgadas de forma transparente. A terminologia empregada pelos legisladores de cada país varia muito, o que dificulta a elaboração de um quadro-síntese comparativo. O grau de detalhamento é altíssimo em alguns países (sobretudo no México) e muito baixo no Equador. Em Honduras e no Paraguai, onde a lei faz apenas exigências genéricas, transcritas textualmente na Tabela 5, que tenta fazer a síntese das informações exigidas. 
Tabela 5. Informações técnicas sobre as pesquisas eleitorais exigidas pela legislação nos países da América Latina

\begin{tabular}{|l|l|}
\hline País & Informações técnicas exigidas \\
\hline Argentina & $\begin{array}{l}\text { Período de realização da pesquisa; tamanho e características da } \\
\text { amostra; margem de erro; questionário; contratante e custo da } \\
\text { pesquisa }\end{array}$ \\
\hline Bolívia & $\begin{array}{l}\text { Período de realização da pesquisa; tamanho e características da da } \\
\text { amostra; margem de erro; questionário; contratante da pesquisa }\end{array}$ \\
\hline Brasil & $\begin{array}{l}\text { Período de realização da pesquisa; tamanho e características da } \\
\text { amostra; margem de erro; questionário; sistema de controle e } \\
\text { verificação; contratante e custo da pesquisa }\end{array}$ \\
\hline Chile & Não há \\
\hline Colômbia & $\begin{array}{l}\text { Período de realização da pesquisa; tamanho e características da } \\
\text { amostra; margem de erro; questionário; contratante da pesquisa }\end{array}$ \\
\hline Costa Rica & $\begin{array}{l}\text { Tamanho e características da amostra; sistema de controle e } \\
\text { verificação }\end{array}$ \\
\hline El Salvador & Não há \\
\hline Equador & $\begin{array}{l}\text { "Procedimentos, análises e apresentação da informação definidos } \\
\text { pela técnica e as ciências sociais" }\end{array}$ \\
\hline Guatemala & Não há \\
\hline Honduras & "Métodos e procedimentos utilizados" \\
\hline México & $\begin{array}{l}\text { Período de realização da pesquisa; data da publicação e meio de } \\
\text { comunicação onde será publicada; tamanho e características da } \\
\text { amostra; questionário; base de dados; contratante da pesquisa }\end{array}$ \\
\hline Nicarágua & Não há \\
\hline Panamá & $\begin{array}{l}\text { Período de realização da pesquisa; tamanho e características da } \\
\text { amostra; margem de erro; questionário; contratante da pesquisa }\end{array}$ \\
\hline Paraguai & Publicação da "ficha técnica" \\
\hline Peru & $\begin{array}{l}\text { Período de realização da pesquisa; data da publicação e meio de de } \\
\text { comunicação onde será publicada; tamanho e características da } \\
\text { amostra; questionário; base de dados; contratante da pesquisa }\end{array}$ \\
\hline $\begin{array}{l}\text { República } \\
\text { Dominicana }\end{array}$ & Não há \\
\hline Uruguai & Não há \\
\hline Venezuela & \\
\hline Fóá
\end{tabular}

Fonte: Legislações eleitorais.

Por fim, o registro das pesquisas e das empresas de pesquisa surgiu na legislação como mais um mecanismo facilitador da fiscalização. No Brasil, a exigência de registrar a realização de uma pesquisa foi introduzida na legislação em 1991, com vistas às eleições municipais do ano seguinte. ${ }^{35}$ Do registro da pesquisa decorreu a consequente necessidade de cadastrar também as pessoas jurídicas que registrassem as pesquisas. Em 2011, uma resolução do Tribunal Superior Eleitoral disciplinou a realização desse cadastro. Em alguns países, a Justiça Eleitoral avalia as credenciais das empresas que se cadastram e decide quais devem ser habilitadas ou não a realizar pesquisas; em outros, como o Brasil, basta a realização do cadastro da empresa, sem que o administrador desse cadastro tenha autoridade para impedi-la de realizar pesquisas. Em alguns países, 
como a Argentina, o cadastro das empresas deve ser renovado a cada eleição; em outros, como o Brasil, basta fazê-lo uma única vez, a qualquer tempo.

Tabela 6. Exigência de registro das empresas de pesquisas nos países da América Latina

\begin{tabular}{|l|l|}
\hline Argentina & Registro na Câmara Nacional Eleitoral \\
\hline Bolívia & Habilitação no Tribunal Supremo Eleitoral \\
\hline Brasil & Registro na Justiça Eleitoral \\
\hline Chile & Não há \\
\hline Colômbia & Registro no Conselho Nacional Eleitoral \\
\hline Costa Rica & Registro no Tribunal Supremo de Eleições \\
\hline El Salvador & Não há \\
\hline Equador & Habilitação no Conselho Nacional Eleitoral \\
\hline Guatemala & Não há \\
\hline Honduras & Registro no Tribunal Supremo Eleitoral \\
\hline México & Registro no Instituto Nacional Eleitoral \\
\hline Nicarágua & Não há \\
\hline Panamá & Registro no Tribunal Eleitoral \\
\hline Paraguai & Não há \\
\hline Peru & Inscrição no Registro Eleitoral de Empresas de Pesquisa \\
\hline República Dominicana & Não há \\
\hline Uruguai & Não há \\
\hline Venezuela & Não há \\
\hline
\end{tabular}

Fonte: Legislações eleitorais.

\subsection{O debate sobre o controle das pesquisas na América Latina}

Em diversas eleições recentes em países latino-americanos, dúvidas sobre a correção das pesquisas foram levantadas por políticos, meios de comunicação e outros setores da sociedade. Essas suspeitas costumam aflorar logo após o período eleitoral, quando ocorre uma discrepância entre o resultado das sondagens e o das eleições, suscitando propostas de modificação da legislação ou de investigação dos procedimentos das empresas de pesquisas. Muitas vezes, porém, passado o interesse do público pelo resultado da eleição, essas propostas tendem a perder força, o que dificulta a implantação de alterações. Em agosto de 2015, a Câmara Nacional Eleitoral da Argentina pediu ao Congresso mais poderes para assegurar que as empresas de pesquisas cumpram a lei eleitoral. ${ }^{36}$ Em outubro de 2015, o Conselho Eleitoral da Colômbia decidiu investigar os resultados das pesquisas relativas às eleições municipais: a empresa Cifras \& Conceptos foi acusada de beneficiar Rafael Pardo, candidato à prefeitura de Bogotá. ${ }^{37}$

${ }^{36}$ Clarín, 1 ago. 2015. 
No Brasil, após as eleições de 1998 e de 2014, congressistas discutiram a possibilidade de criar uma Comissão Parlamentar de Inquérito para investigar as pesquisas eleitorais. Em ambas ocasiões, a ideia foi combatida por parte dos meios de comunicação, notadamente a Folha de S. Paulo, jornal cujo grupo empresarial é proprietário de uma das principais empresas de pesquisas do país, o Datafolha. Nos dois casos, os argumentos dos editoriais do jornal são os mesmos: direito à liberdade de expressão e direito do eleitor à informação. O argumento, porém, evoluiu no que diz respeito ao objetivo das pesquisas: se em 1998 falava-se no esforço das empresas para aumentar a precisão dos levantamentos, em 2015 elidia-se completamente a questão, alegando que os levantamentos não têm a intenção de prever o resultado das eleições, e sim de "retratar" um momento específico da campanha eleitoral. Contrastem-se as argumentações dos dois editoriais abaixo, separados no tempo por dezessete anos:

Há paternalismo porque se pretende tutelar a sociedade, julgando-a incapaz de usufruir da democracia, a qual implica confronto de influências, idéias e informações. $\mathrm{O}$ autoritário não acredita que as instituições democráticas e seus instrumentos se aperfeiçoem por meio da livre controvérsia. Vale lembrar a esse respeito que, na recente eleição, institutos de pesquisa procuraram incrementar a precisão de seus levantamentos - e assim resguardar sua credibilidade e sua probidade - depois da polêmica acesa pela comparação entre os resultados das urnas e os das sondagens de intenção de voto. A solução é, pois, mais debate - o da CPI ou outros - e mais pesquisas livremente divulgadas. O eleitor tem o direito de escolher em que acreditar. (“A CPI das pesquisas". Folha de S. Paulo, 8 nov. 1998, p. A-2)

Ao justificar a proposta, o deputado [Ricardo Barros] revela desconhecimento acerca do assunto. Afirma, por exemplo, que os levantamentos não podem "incorrer em erros maiores do que a margem estipulada", como se as pesquisas e as urnas computassem o mesmo fenômeno. Como diretores de institutos já repetiram à exaustão, os números sobre intenção de voto retratam um momento específico, não podendo ser considerados como previsão de resultados - de resto, registram intentos, não votos. Afora essa questão de fundo, o projeto de censura - pois disso se trata esbarra numa dificuldade prática incontornável. Uma vez aplicada a restrição às pesquisas baseadas em metodologias conhecidas, nada impediria que circulassem boatos diversos na internet. Nesse cenário, o eleitor permaneceria duas semanas exposto a rumores de toda natureza, sem ter o contraponto de institutos que se oferecem ao escrutínio da sociedade, dos candidatos e da Justiça. (“CPI da ignorância”. Folha de S. Paulo, 18 fev. 2015, p. A-2)

Nos países de baixo grau de controle sobre as pesquisas, discute-se a implantação de legislação do gênero. No Uruguai, em 2014, Daniel Mordecki, consultor da IBM e professor da Universidade ORT, de Montevidéu, propôs a adoção de uma ley

\footnotetext{
${ }^{37}$ El Espectador, 6 out. 2015.
} 
de encuestas, baseada em três pilares: o registro de que uma pesquisa será realizada; a publicação dos dados "crus" da pesquisa, ou seja, sem processamento; e a indicação das fontes de dados usadas eventualmente para a ponderação dos números, como recenseamentos e pesquisas anteriores. ${ }^{38}$ A proposta de Mordecki foi motivada pelas discrepâncias entre os números de diferentes empresas durante a campanha eleitoral de 2014. No Chile, alguns trabalhos acadêmicos se debruçaram sobre a questão. ${ }^{39}$

As tentativas de implantar mecanismos de controle sobre a realização e a divulgação de pesquisas eleitorais não impediram a continuidade das críticas ao trabalho das empresas que realizam esses levantamentos. Nas eleições brasileiras de 2014, as críticas ficaram centradas nos pleitos estaduais, em que alguns resultados das urnas ficaram fora das "margens de erro" anunciadas pelos pesquisadores. Na eleição presidencial argentina de 2015, as empresas de pesquisas, conhecidas como consultoras, foram acusadas no primeiro turno de subestimar a votação que viria a ter o principal candidato da oposição, Mauricio Macri; e, no segundo turno, de superestimar a votação do mesmo Macri. Na maioria dos casos, os responsáveis pelas pesquisas saem-se com a justificativa da volatilidade, de uma suposta tendência do eleitor a decidir-se cada vez mais perto do dia do voto. Desconhece-se, porém, a existência de estudos aprofundados que busquem aferir essa suposta tendência.

Algumas provisões das legislações dos países latino-americanos têm pouca eficácia no sentido de coibir abusos por parte dos realizadores de pesquisas. É o caso dos incisos I e VII do artigo $2^{\circ}$ da Resolução 23.400, do Tribunal Superior Eleitoral do Brasil, que dispõe sobre as pesquisas eleitorais para as eleições de 2014. Eles preveem que as empresas que realizam as pesquisas são obrigadas a registrar "quem contratou a pesquisa" e "o nome de quem pagou pela realização do trabalho". Porém, em diversas

pesquisas a própria empresa de pesquisa se apresenta como a contratante do levantamento, numa evidente burla do espírito da norma. Essa brecha na legislação permite a existência de clientes "anônimos", ferindo a intenção de transparência do legislador. Esse é apenas um exemplo de aperfeiçoamentos que podem ser introduzidos para eleições futuras.

\footnotetext{
${ }^{38}$ MORDECKI (2014).

39 LÓPEZ et alii (2009); BIBLIOTECA DEL CONGRESO NACIONAL DE CHILE (2012).
} 
Outro problema é a insuficiência de dados que possibilitem a replicação das pesquisas. Manda o método científico que o autor de um estudo ponha à disposição de outros estudiosos todas as informações que possibilitem aos demais essa replicação. Nesse ponto as pesquisas continuam a ser uma "caixa preta". Nesse sentido, a proposta do uruguaio Daniel Mordecki, citada acima, de publicação dos dados "crus" da pesquisa, tem o mérito de permitir a refutabilidade necessária num trabalho que se pretende científico. Restaria saber como compatibilizar essa necessidade com a indispensável proteção da privacidade dos entrevistados.

No Brasil, uma brecha da legislação permite a ocorrência pura e simples de fraudes. A regulamentação do registro de pesquisas exige que se declare o nome de um estatístico responsável. Porém, não há qualquer fiscalização da veracidade dos dados informados. Isto levou algumas empresas de pesquisa a utilizar falsamente nomes de estatísticos que não participaram da realização dos levantamentos (e que em alguns casos nem sequer trabalham com pesquisas eleitorais), bem como seus números de registro junto aos Conselhos Regionais de Estatística. A fraude foi denunciada à imprensa pelo Conselho Regional de Estatística da Terceira Região, que abrange os estados de Mato Grosso, Mato Grosso do Sul, Paraná e São Paulo (DUARTE, 2016).

Diversos profissionais do ramo da estatística defendem alterações na legislação brasileira para coibir a ocorrência de fraudes na realização e divulgação de pesquisas. Uma delas seria permitir que representantes do Conselho Federal de Estatística ou dos Conselhos Regionais de Estatística tivessem acesso aos "microdados" das pesquisas eleitorais, de modo a detectar possíveis manipulações. Hoje a legislação brasileira só permite acesso a esses microdados mediante decisão judicial, por iniciativa de partidos políticos e em caso de suspeita fundada de fraude, o que na prática inviabiliza a fiscalização detalhada do trabalho das empresas de pesquisa.

No momento de redação desta dissertação, tramitava no Senado brasileiro o Projeto de Lei da Câmara 138/2010, regulamentando as "profissões de pesquisador de mercado, opinião e mídia e de técnico de pesquisa de mercado, opinião e mídia”. Caso venha a ser transformado em lei, passará a exigir curso superior para o exercício da profissão de pesquisador, e curso médio para o exercício da profissão de técnico. Os conselhos de estatística se opõem ao projeto, por temer que ele represente restrições à atividade do estatístico. 
Em alguns países, propôs-se solucionar essas questões por meio da autorregulamentação. Existe uma associação internacional que congrega entidades do gênero de diversos países, a Wapor (sigla em inglês para Associação Mundial de Pesquisa de Opinião Pública). Ela possui um Código de Ética que estabelece normas de conduta dos pesquisadores em relação aos clientes, em relação aos entrevistados e entre os próprios pesquisadores. Também publica materiais de publicidade e defesa do trabalho das empresas de pesquisa, como estudos acadêmicos, manuais de instruções para a realização de pesquisas eleitorais e guias para o uso de jornalistas. A Wapor é um filhote da Aapor, a associação correspondente nos Estados Unidos, fundada em 1947 por iniciativa de George Gallup e outros pesquisadores.

Em pelo menos um país latino-americano, a Colômbia, a tentativa de autorregulamentação não tem sido bem-sucedida. Graças a um acordo entre o Conselho Nacional Eleitoral e as empresas de pesquisas, desde 2002 prevalece uma autorregulamentação. Nas eleições municipais de 2015, porém, como exposto acima, as suspeitas de fraude puseram em xeque esse sistema. ${ }^{40}$

Na América Latina a legislação não tem sido capaz de impedir a recorrência de pesquisas suspeitas e de controvérsias em relação a seus números. Na prática, os mecanismos de controle mais eficientes da veracidade das pesquisas fogem ao alcance da lei: a comparação entre os números dos diferentes levantamentos e, no dia da eleição, a comparação entre estes e o resultado da votação propriamente dita.

\section{6. $O$ debate atual sobre o uso das pesquisas}

Algumas iniciativas, em países de outras regiões do globo, indicam que tende a crescer o debate em torno do uso das pesquisas pelos meios de comunicação. Em janeiro de 2017, o diário francês Le Parisien - um dos maiores da França, com mais de 340 mil exemplares diários -, anunciou que não realizaria nem publicaria resultados de pesquisas de intenção de voto relativas à eleição presidencial francesa marcada para os meses de abril e maio. "Não é uma questão de desafiar os pesquisadores, mas uma

\footnotetext{
${ }^{40}$ OROZCO TASCÓN (2015).
} 
maneira de trabalhar de maneira diferente, que queremos testar na sequência da campanha", explicou o diretor de redação, Stéphane Albouy ${ }^{41}$.

Conhecido pelo amplo uso de pesquisas em suas manchetes, o Le Parisien justificou sua decisão com a intenção de dedicar mais espaço a reportagens que deem voz aos eleitores, que tentem captar o estado de espírito dos eleitores menos por intermédio dos números e mais através de entrevistas. É impossível ignorar, porém, a influência, sobre essa decisão, de uma série de discrepâncias notórias entre pesquisas divulgadas às vésperas de pleitos e o resultado real das urnas. Três casos chamaram a atenção em particular no ano de 2016:

- Em junho, no referendo organizado no Reino Unido para decidir a permanência ou saída da União Europeia, triunfou o Leave (saída), com 52\% dos votos válidos, enquanto no dia da eleição a média das pesquisas apontava a vitória do Remain (permanência).

- Em outubro, no plebiscito organizado pelo governo colombiano para aprovar ou rejeitar o acordo de paz com as Farc (Forças Armadas Revolucionárias da Colômbia), as pesquisas previam a vitória do Sí (aprovação), mas triunfou o No (rejeição), por uma margem de apenas meio ponto percentual. Um levantamento realizado apenas cinco dias antes da votação atribuía $66 \%$ das preferências ao $S i ́$, que acabaria recolhendo $49,8 \%$ dos votos válidos. Parte dessa diferença foi atribuída às fortes chuvas que se abateram sobre regiões do país onde o Sí prevalecia com mais força; considerando-se que a abstenção foi superior a $62 \%$, também se pode conjecturar que a própria vantagem do Sí nas pesquisas tenha perversamente contribuído para o resultado final, ao dissuadir eleitores favoráveis ao acordo a sair de casa para depositar seu voto.

- Em novembro, na eleição presidencial dos Estados Unidos, o candidato republicano, Donald Trump, reuniu um número de votos no Colégio Eleitoral superior ao de sua adversária, a democrata Hillary Clinton. Embora as empresas de pesquisa tenham acertado, em sua maioria, ao prever que Clinton obteria um maior número de votos no conjunto do eleitorado americano (ou, no jargão eleitoral americano, triunfaria

\footnotetext{
${ }^{41}$ Le Monde, 5 jan. 2017.
} 
no "voto popular"), não estimaram corretamente a possibilidade de Trump obter maioria em estados de inclinação democrata, notadamente Michigan, Pensilvânia e Wisconsin, cujos votos bastaram para fazer a eleição pender em seu favor.

No momento em que esta dissertação era redigida, ainda era muito cedo para dizer que efeitos a decisão do Le Parisien teria sobre a abordagem dos meios de comunicação como um todo em relação às pesquisas - se será lembrada apenas como uma exceção anedótica ou se virá a ser um exemplo seguido por outros veículos. O próprio jornal não descartou a possibilidade de comentar pesquisas feitas por concorrentes, e não se pode descartar motivações menos nobres para a decisão de não realizar sondagens, como a economia de recursos (Albouy reconheceu na mesma entrevista que o Parisien gasta dezenas de milhões de euros por ano com pesquisas) ou o simples desejo de obter publicidade à custa da imagem negativa recente desse tipo de levantamento. Seja como for, a experiência permitirá, na pior das hipóteses, uma comparação entre a abordagem do Parisien e a dos demais veículos de comunicação ao longo da campanha presidencial francesa.

Bem-sucedida ou não a renúncia parcial do Parisien, ela poderá estimular o debate sobre o uso das pesquisas de opinião na cobertura jornalística das campanhas eleitorais. A discussão não é nova, é bem verdade (ATKIN e GAUDINO, 1984; STRÖMBACK, 2012), mas algumas iniciativas parecem representar um esforço inédito para "ouvir a voz das ruas", para buscar uma cobertura menos numérica e mais "de carne e osso". No Brasil, a Folha de S. Paulo criou na campanha presidencial de 2014 a seção "Painel do Eleitor", em que o colunista Marcelo Coelho entrevistou eleitores "selecionados pelo Datafolha conforme características de idade, renda e escolaridade específicas”, correspondentes “aos padrões mais 'típicos' de quem vota em Dilma Rousseff (PT), Marina Silva (PSB) ou Aécio Neves (PSDB) na Grande São Paulo" (COELHO, 2014). Pode-se apontar fragilidades nessa intenção - por exemplo, o fato de ter se limitado à região metropolitana de São Paulo, embora se trate de uma eleição nacional, e de um jornal de alcance nacional; e a decisão de ouvir apenas eleitores dos três candidatos mais bem situados nas pesquisas (que acabaram, assim, por influenciar o agendamento da cobertura). Por que não ouvir também eleitores de Luciana Genro, Pastor Everaldo ou Eduardo Jorge, por exemplo? O simples surgimento da discussão, porém, indica o reconhecimento de uma insuficiência da cobertura eleitoral, do ponto de vista qualitativo. 
Nos Estados Unidos, a percepção de que os mainstream media foram surpreendidos pela vitória de Trump na eleição presidencial de 2016 levou a um debate sobre futuras coberturas, que procurem ir ao encontro dos eleitores da "América profunda" (SPAYD, 2016).

Neste capítulo examinamos alguns aspectos da regulamentação da realização e divulgação das pesquisas eleitorais que afetam a forma como elas são apresentadas pelos meios de comunicação. No próximo capítulo, buscaremos situar o contexto em que se deram as eleições presidenciais de 2014 no Brasil e 2015 na Argentina, como base para o estudo comparativo a que nos propomos, apresentando os candidatos e as regras de cada eleição; o perfil dos candidatos, a cronologia da campanha eleitoral e os números apresentados pelas pesquisas em cada país. 


\section{Brasil e Argentina: um estudo comparado}

\subsection{O contexto político}

Os processos políticos nas sociedades da América Latina muitas vezes apresentam paralelismos temporais, reflexo de condições históricas e econômicas regionais que apresentam certas similaridades. Podemos citar como exemplo desses paralelismos o período marcado por golpes militares e ditaduras, sobretudo entre os anos 1960 e 1980; os elevados índices de inflação que assolaram muitas economias do continente nos anos 1980 e 1990; e até detalhes do sistema político, como a adoção, por várias nações latino-americanas, da possibilidade de reeleição do presidente da República, a partir dos anos 1990.

Entre os vizinhos Brasil e Argentina também se encontram muitos desses paralelismos. Na conjuntura política e econômica, aqueles que podem ser considerados mais relevantes para os fins deste trabalho, no que diz respeito ao contexto das respectivas eleições presidenciais, são o longo período de permanência no poder de governos de esquerda; a existência de uma candidatura de "terceira via", a meio caminho, no espectro político, entre governo e oposição; e um contexto econômico marcado pela queda do valor das commodities no mercado internacional, com forte impacto sobre os indicadores econômicos dos chamados países "emergentes".

Dentre as especificidades mais significativas separando as conjunturas dos dois países podem-se citar as investigações por corrupção envolvendo altas autoridades do governo brasileiro, no âmbito dos chamados escândalos do Mensalão (este mais antigo, remontando à eleição de 2006) e da Operação Lava-Jato; e, no caso argentino, a dificuldade do país em restabelecer seu crédito junto ao mercado financeiro global, ainda em razão da moratória decretada em 2001 e da reestruturação da dívida realizada em 2005. Essas questões específicas tiveram impacto nas respectivas campanhas eleitorais e serão abordadas mais detalhadamente ao falarmos de agendamento. Na Tabela 7, a seguir, é possível observar algumas semelhanças políticas e econômicas, entre as situações políticas e econômicas de Brasil e Argentina, que consideramos relevantes para este trabalho. Essas semelhanças dizem respeito aos grupos políticos ocupantes do poder no momento das eleições, ao perfil dos candidatos à presidência 
com mais intenções de voto nas pesquisas de opinião e à conjuntura econômica no período da campanha eleitoral.

Tabela 7 - Semelhanças entre as conjunturas político-econômicas de Brasil (2014) e Argentina (2015)

\begin{tabular}{|c|c|c|}
\hline Brasil (2014) & & Argentina (2015) \\
\hline $\begin{array}{l}\text { Governo considerado de esquerda, } \\
\text { no poder há três mandatos (dois de } \\
\text { Lula e um de Dilma Rousseff), desde } \\
2003\end{array}$ & Grupo no poder & $\begin{array}{c}\text { Governo considerado de esquerda, } \\
\text { no poder há três mandatos (um de } \\
\text { Néstor Kirchner e dois de Cristina } \\
\text { Fernández), desde } 2003\end{array}$ \\
\hline $\begin{array}{c}\text { Candidata do governo (Dilma } \\
\text { Rousseff) com chances de eleição } \\
\text { no primeiro turno; duas } \\
\text { candidaturas principais de oposição, } \\
\text { uma considerada mais à direita } \\
\text { (Aécio Neves) e outra de "terceira } \\
\text { via", representada por uma ex- } \\
\text { integrante do governo (Marina } \\
\text { Silva) }\end{array}$ & $\begin{array}{l}\text { Candidatos à } \\
\text { presidência }\end{array}$ & $\begin{array}{l}\text { Candidato do governo (Daniel Scioli) } \\
\text { com chances de eleição no primeiro } \\
\text { turno; duas candidaturas principais } \\
\text { de oposição, uma considerada mais } \\
\text { à direita (Mauricio Macri) e outra de } \\
\text { "terceira via", representada por um } \\
\text { ex-integrante do governo (Sergio } \\
\text { Massa) }\end{array}$ \\
\hline $\begin{array}{c}\text { Piora dos indicadores econômicos, } \\
\text { com previsão de baixo crescimento } \\
\text { e aumento do endividamento } \\
\text { público }\end{array}$ & $\begin{array}{l}\text { Perspectiva } \\
\text { econômica }\end{array}$ & $\begin{array}{c}\text { Piora dos indicadores econômicos, } \\
\text { com previsão de baixo crescimento } \\
\text { e aumento do endividamento } \\
\text { público }\end{array}$ \\
\hline
\end{tabular}

Fonte: Elaboração própria.

No período específico que nos interessa, é importante relacionar os elementos em comum e aqueles que diferenciam os dois países no contexto imediatamente anterior às respectivas eleições presidenciais. As Tabelas 8 e 9 , sem a pretensão de dar conta de maneira exaustiva de semelhanças e diferenças, resumem o contexto em que os dois países realizaram suas eleições, tanto do ponto de vista das características dos sistemas político-eleitorais quanto dos marcos legais de ambos os países. Um exemplo da importância do conhecimento dessas informações diz respeito a regras específicas dos respectivos sistemas eleitorais: enquanto no Brasil é preciso obter $50 \%$ mais um dos votos válidos para vencer a eleição presidencial no primeiro turno, na Argentina esse "piso" é de $45 \%$, ou até mesmo $40 \%$ caso o segundo colocado fique dez pontos percentuais atrás. Essa diferença, como seria de esperar, informa e afeta a análise das pesquisas de opinião e o cálculo político dos diversos atores envolvidos na campanha eleitoral. As tabelas não levam em conta modificações nas leis eleitorais posteriores à última eleição presidencial de cada país. 
Tabela 8 - Características dos sistemas político-eleitorais brasileiro (2014) e argentino (2015)

\begin{tabular}{|c|c|c|}
\hline Brasil (2014) & & Argentina (2015) \\
\hline 26 estados e Distrito Federal & Divisão política & 23 províncias e Distrito Federal \\
\hline 201.032.714 (estimativa 2014) & População & 43.131.966 (estimativa 2015) \\
\hline $142.822 .046(2014)$ & Eleitorado apto & $32.064 .323(2015)$ \\
\hline República presidencialista & Sistema de governo & República presidencialista \\
\hline $\begin{array}{l}\text { Bicameral (513 deputados federais e } \\
\qquad 81 \text { senadores) }\end{array}$ & Parlamento & $\begin{array}{c}\text { Bicameral (257 deputados nacionais } \\
\text { e } 72 \text { senadores) }\end{array}$ \\
\hline $\begin{array}{l}4 \text { anos, com possibilidade de uma } \\
\text { reeleição consecutiva }\end{array}$ & $\begin{array}{l}\text { Mandato } \\
\text { presidencial }\end{array}$ & $\begin{array}{l}4 \text { anos, com possibilidade de uma } \\
\text { reeleição consecutiva }\end{array}$ \\
\hline $\begin{array}{c}4 \text { anos, com renovação integral a } \\
\text { cada eleição }\end{array}$ & $\begin{array}{c}\text { Mandato dos } \\
\text { deputados }\end{array}$ & $\begin{array}{c}4 \text { anos, com renovação de metade } \\
\text { das cadeiras a cada } 2 \text { anos }\end{array}$ \\
\hline $\begin{array}{l}8 \text { anos, com renovação alternada de } \\
1 / 3 \text { e } 2 / 3 \text { a cada } 4 \text { anos }\end{array}$ & $\begin{array}{l}\text { Mandato dos } \\
\text { senadores }\end{array}$ & $\begin{array}{c}6 \text { anos, com renovação de um terço } \\
\text { a cada } 2 \text { anos }\end{array}$ \\
\hline $\begin{array}{l}\text { Brasileiros natos e naturalizados: } \\
\text { voto obrigatório entre os } 18 \text { e os } 70 \\
\text { anos e facultativo entre } 16 \text { e } 18 \text { e } \\
\text { após os } 70 \text { anos }\end{array}$ & Habilitados a votar & $\begin{array}{l}\text { Argentinos natos, a partir dos } 16 \\
\text { anos, e naturalizados, a partir dos } 18 \\
\text { anos. Voto obrigatório }\end{array}$ \\
\hline Convenções partidárias & $\begin{array}{l}\text { Sistema de escolha } \\
\text { dos candidatos }\end{array}$ & $\begin{array}{c}\text { Convenções partidárias, seguidas de } \\
\text { primárias "abertas, simultâneas e } \\
\text { obrigatórias" (PASO) }\end{array}$ \\
\hline $\begin{array}{c}\text { Dois turnos, ocorrendo segundo } \\
\text { turno caso nenhum candidato } \\
\text { alcance mais de } 50 \% \text { dos votos } \\
\text { válidos }\end{array}$ & $\begin{array}{l}\text { Sistema de eleição } \\
\text { do presidente }\end{array}$ & $\begin{array}{l}\text { Dois turnos, ocorrendo segundo } \\
\text { turno caso nenhum candidato } \\
\text { alcance mais de } 45 \% \text { dos votos } \\
\text { válidos e brancos ou mais de } 40 \% \\
\text { com dez pontos percentuais de } \\
\text { vantagem sobre os demais }\end{array}$ \\
\hline $\begin{array}{c}4 \text { anos, com renovação integral a } \\
\text { cada eleição }\end{array}$ & $\begin{array}{l}\text { Mandato dos } \\
\text { deputados }\end{array}$ & $\begin{array}{c}4 \text { anos, com renovação de metade } \\
\text { das cadeiras a cada } 2 \text { anos }\end{array}$ \\
\hline $\begin{array}{c}8 \text { anos, com renovação alternada de } \\
1 / 3 \text { e } 2 / 3 \text { a cada } 4 \text { anos }\end{array}$ & $\begin{array}{l}\text { Mandato dos } \\
\text { senadores }\end{array}$ & $\begin{array}{c}6 \text { anos, com renovação de um terço } \\
\text { a cada } 2 \text { anos }\end{array}$ \\
\hline $\begin{array}{c}\text { Tribunal Superior Eleitoral (órgão do } \\
\text { Poder Judiciário) }\end{array}$ & $\begin{array}{c}\text { Organizador das } \\
\text { eleições }\end{array}$ & $\begin{array}{c}\text { Dirección Nacional Electoral } \\
\text { (vinculada ao Ministério da Justiça) }\end{array}$ \\
\hline Voto eletrônico & Modo de votação & $\begin{array}{c}\text { Cédula de papel (existe voto } \\
\text { eletrônico nas províncias de Salta e } \\
\text { Buenos Aires) }\end{array}$ \\
\hline $\begin{array}{c}\text { Presidente, } 27 \text { governadores, } \\
\text { Câmara dos Deputados, Senado } \\
\text { Federal, assembleias legislativas } \\
\text { estaduais }\end{array}$ & Cargos em disputa & $\begin{array}{l}\text { Presidente, } 11 \text { governadores, } \\
\text { Câmara de Deputados, Senado da } \\
\text { Nação, legislaturas provinciais, } \\
\text { Parlamento do Mercosul }\end{array}$ \\
\hline $\begin{array}{c}32 \text { partidos nacionais com registro } \\
\text { junto ao TSE (2014) }\end{array}$ & Partidos políticos & $\begin{array}{c}38 \text { partidos nacionais e } 596 \text { distritais } \\
\text { reconhecidos pela Câmara Nacional } \\
\text { Eleitoral (2015) }\end{array}$ \\
\hline $\begin{array}{l}47 \text { dias antes do primeiro turno e } 15 \\
\text { dias antes do segundo turno }\end{array}$ & $\begin{array}{l}\text { Campanha gratuita } \\
\text { em rádio e } \\
\text { televisão }\end{array}$ & $\begin{array}{l}25 \text { dias antes do primeiro turno e } 12 \\
\text { dias antes do segundo turno }\end{array}$ \\
\hline $\begin{array}{l}\text { Permitido o financiamento por } \\
\text { pessoas físicas e jurídicas }\end{array}$ & $\begin{array}{l}\text { Financiamento das } \\
\text { campanhas }\end{array}$ & $\begin{array}{l}\text { Permitido o financiamento por } \\
\text { pessoas físicas e jurídicas }\end{array}$ \\
\hline
\end{tabular}


Tabela 9 - Legislação relativa a pesquisas eleitorais no Brasil e na Argentina

\begin{tabular}{|c|c|c|}
\hline Brasil & & Argentina \\
\hline $\begin{array}{l}\text { Lei ordinária e resoluções do } \\
\text { Tribunal Superior Eleitoral }\end{array}$ & Tipo de legislação & $\begin{array}{l}\text { Lei ordinária e acórdãos da Câmara } \\
\text { Nacional Eleitoral }\end{array}$ \\
\hline $\begin{array}{c}\text { Cadastro a qualquer tempo junto à } \\
\text { Justiça Eleitoral (Resolução TSE } \\
23.400 / 2013 \text { ) }\end{array}$ & $\begin{array}{l}\text { Registro de empresas } \\
\text { de pesquisas }\end{array}$ & $\begin{array}{c}\text { Registro junto à Câmara Nacional } \\
\text { Eleitoral, renovado a cada eleição } \\
\text { (Lei 26.571/2009) }\end{array}$ \\
\hline $\begin{array}{l}\text { Obrigatório pelo menos cinco dias } \\
\text { antes da divulgação dos resultados } \\
\text { (Lei 9.504/1997) }\end{array}$ & Registro de pesquisas & $\begin{array}{c}\text { Obrigatório a qualquer tempo antes } \\
\text { da realização da pesquisa (Lei } \\
26.571 / 2009 \text { ) } \\
\end{array}$ \\
\hline $\begin{array}{l}\text { Metodologia e período de } \\
\text { realização da pesquisa; plano } \\
\text { amostral e ponderação quanto a } \\
\text { sexo, idade, grau de instrução e } \\
\text { nível econômico do entrevistado, } \\
\text { área física de realização do } \\
\text { trabalho, margem de erro e nível } \\
\text { de confiança; sistema interno de } \\
\text { controle e verificação, conferência } \\
\text { e fiscalização da coleta de dados e } \\
\text { do trabalho de campo; } \\
\text { questionário completo aplicado ou } \\
\text { a ser aplicado (Res. TSE } \\
23.400 / 2013)\end{array}$ & $\begin{array}{l}\text { Informações técnicas } \\
\text { exigidas no registro } \\
\text { da pesquisa }\end{array}$ & $\begin{array}{l}\text { Metodologia científica utilizada, tipo } \\
\text { de pesquisa realizada, tamanho e } \\
\text { características da amostra utilizada, } \\
\text { procedimento de seleção dos } \\
\text { entrevistados, margem de erro } \\
\text { estatístico aplicável, data do } \\
\text { trabalho de campo e nível de } \\
\text { confiança (Acórdão CNE } 117 / 2010 \text { ) }\end{array}$ \\
\hline $\begin{array}{l}\text { Quem contratou a pesquisa; valor } \\
\text { e origem dos recursos } \\
\text { despendidos no trabalho; nome de } \\
\text { quem pagou pela realização do } \\
\text { trabalho; nome do estatístico } \\
\text { responsável pela pesquisa e o } \\
\text { número de seu registro no } \\
\text { Conselho Regional de Estatística } \\
\text { (Res. TSE 23.400/2013) }\end{array}$ & $\begin{array}{c}\text { Informações } \\
\text { adicionais exigidas }\end{array}$ & $\begin{array}{l}\text { Dados de quem realizou a } \\
\text { contratação e preço cobrado; } \\
\text { designação de um responsável } \\
\text { técnico com título habilitante em } \\
\text { relação direta com as tarefas a } \\
\text { realizar e, para cada pesquisa de } \\
\text { opinião, a designação de um } \\
\text { responsável técnico específico } \\
\text { (Acórdão CNE 117/2010) }\end{array}$ \\
\hline $\begin{array}{l}\text { Período de realização da coleta de } \\
\text { dados; margem de erro; nível de } \\
\text { confiança; número de entrevistas; } \\
\text { nome da entidade ou empresa que } \\
\text { a realizou e, se for o caso, de quem } \\
\text { a contratou; número de registro da } \\
\text { pesquisa (Res. TSE } 23.400 / 2013 \text { ) }\end{array}$ & $\begin{array}{l}\text { Exigências em } \\
\text { relação à divulgação } \\
\text { de pesquisas }\end{array}$ & $\begin{array}{c}\text { "Citar a fonte da informação, dando } \\
\text { a conhecer o detalhamento técnico } \\
\text { do trabalho realizado" (Lei } \\
26.571 / 2009 \text { ) }\end{array}$ \\
\hline $\begin{array}{l}\text { Proibida apenas a divulgação de } \\
\text { pesquisas de boca-de-urna (feitas } \\
\text { no dia da eleição) até o } \\
\text { fechamento das urnas (Res. TSE } \\
23.400 / 2013 \text { ) }\end{array}$ & $\begin{array}{l}\text { Restrições à } \\
\text { divulgação de } \\
\text { pesquisas }\end{array}$ & $\begin{array}{l}\text { Proibida toda divulgação oito dias } \\
\text { antes da eleição (Lei 26.571/2009) }\end{array}$ \\
\hline
\end{tabular}

Fontes: Centro de Documentación e Información, Ministerio de Economía e Finanzas Públicas; Cámara Nacional Electoral (Argentina); Tribunal Superior Eleitoral (Brasil). 


\subsubsection{A eleição presidencial brasileira de 2014}

\subsubsection{Os candidatos}

A eleição presidencial de 2014 foi a sétima de tipo direto desde o fim da ditadura militar de 1964-85 e a promulgação da Constituição em vigor, em 1988 (os pleitos anteriores ocorreram em 1989, 1994, 1998, 2002, 2006 e 2010), o que representa um período inédito de continuidade democrática no Brasil. ${ }^{42}$ Ela opôs 11 candidatos, dos quais apenas quatro tiveram $1 \%$ ou mais dos votos válidos: por ordem de votação, Dilma Rousseff (Partido dos Trabalhadores), Aécio Neves (Partido da Social Democracia Brasileira), Marina Silva (Partido Socialista Brasileiro) e Luciana Genro (Partido Socialismo e Liberdade) $^{43}$. Simultaneamente ao primeiro turno da eleição presidencial foram realizados os primeiros turnos das eleições dos governadores das 27 unidades da federação (26 estados mais o Distrito Federal), para a renovação integral da Câmara dos Deputados e das assembleias legislativas e de um terço das cadeiras do Senado Federal. Esboçamos os dados biográficos dos principais candidatos, por ordem de votação no primeiro turno:

Dilma Rousseff (1947-), a presidente em exercício desde 2011, foi o terceiro chefe do Executivo a pleitear a reeleição desde que, em 1997, uma emenda à Constituição permitiu, pela primeira vez na história do Brasil, que isso ocorresse ${ }^{44}$. Dilma, como é conhecida, militou na luta armada contra a ditadura no início dos anos

\footnotetext{
${ }^{42}$ Na chamada República Velha (1889-1930), houve 11 eleições presidenciais diretas, mas dificilmente elas podem ser classificadas como "livres", pois eram fraudadas e apenas serviam para homologar os candidatos escolhidos nos conchavos da elite. Em 1926, por exemplo, Washington Luís recebeu 99,7\% dos votos. Apenas em 1910 (Hermes da Fonseca contra Ruy Barbosa), 1919 (Epitácio Pessoa contra Ruy Barbosa), 1922 (Artur Bernardes contra Nilo Peçanha) e 1930 (Júlio Prestes contra Getúlio Vargas) podese falar efetivamente em disputa eleitoral, embora o vencedor fosse sempre conhecido de antemão. A contestação ao resultado de 1930 levou à revolução que conduziu Vargas ao Palácio do Catete.

${ }^{43}$ Os demais candidatos, pela ordem que teriam na votação, foram: Pastor Everaldo (Partido Social Cristão), Eduardo Jorge (Partido Verde), Levy Fidelix (Partido Renovador Trabalhista Brasileiro), Zé Maria (Partido Socialista dos Trabalhadores Unificado), José Maria Eymael (Partido Social Democrata Cristão), Mauro Iasi (Partido Comunista Brasileiro) e Rui Costa Pimenta (Partido da Causa Operária).

${ }^{44} \mathrm{O}$ instituto da reeleição para períodos consecutivos acompanhava uma tendência que seria constatada em diversos países da América do Sul no mesmo período, em que presidentes em exercício, tirando proveito de momentos de popularidade em alta, fizeram alterar a lei eleitoral para possibilitar a própria permanência no cargo. Foi assim no Peru, com Alberto Fujimori (1993); na Argentina, com Carlos Menem (1994); no Brasil, com Fernando Henrique Cardoso (1997); na Venezuela, com Hugo Chávez (1999); na Bolívia, com Evo Morales (2006); e no Equador, com Rafael Correa (2008).
} 
70, tendo sido presa e torturada. Na redemocratização, fez carreira na administração pública do Rio Grande do Sul, inicialmente como filiada ao Partido Democrático Trabalhista (PDT) de Leonel Brizola, e posteriormente ao PT. A reputação de boa gestora lhe valeu a nomeação para os ministérios das Minas e Energia e da Casa Civil do governo Lula (2003-11). Em 2010, foi escolhida por Lula como candidata à sua sucessão, mesmo sem jamais ter concorrido a um cargo eletivo, uma vez que José Dirceu e Antonio Palocci, líderes do PT cogitados anteriormente como pré-candidatos, ficaram inviabilizados em virtude de escândalos de corrupção. Mercê da popularidade e do apoio de Lula, Dilma se tornou a primeira mulher a presidir o Brasil, eleita no segundo turno de 2010 com 56\% dos votos válidos, contra José Serra, do PSDB. Seu companheiro de chapa foi o mesmo de 2010, o vice-presidente Michel Temer, do PMDB (Partido do Movimento Democrático Brasileiro).

Aécio Neves (1960-), candidato do PSDB, foi considerado por muitos como "predestinado" à presidência desde que se tornou conhecido da opinião pública em 1984, como secretário particular do avô, Tancredo Neves, primeiro presidente do regime democrático inaugurado em $1985 .{ }^{45}$ Deputado federal (1987-2002), governador de Minas Gerais (2003-11) e senador pelo mesmo estado desde 2011, Aécio foi aventado como potencial candidato do PSDB à presidência em 2010, mas o partido o fez "ceder a vez" a José Serra, então governador de São Paulo. Em 2014, era o nome "natural" de seu partido. Seu companheiro de chapa foi outro senador do mesmo partido, Aloysio Nunes Ferreira, de São Paulo.

Marina Silva (1958-) surgiu dos quadros do PT, como uma das herdeiras políticas do líder seringueiro acriano Chico Mendes, assassinado em 1988. De família pobre, alfabetizou-se aos 16 anos, superou diversos problemas de saúde e tornou-se professora secundária. Sua trajetória singular lhe valeu notoriedade nacional em 1994, ao eleger-se a mais jovem senadora do país, pelo estado do Acre. Ministra do Meio Ambiente de Lula (2003-08), deixou o cargo (e, posteriormente, o PT) por discordar da política ambiental do governo. Em 2010, candidatou-se à presidência pelo Partido Verde (PV), ficando em terceiro lugar no primeiro turno, com 19\% dos votos. No início de 2014 , tendo fracassado por pouco na coleta de assinaturas para a criação de um novo

\footnotetext{
${ }^{45}$ Eleito em janeiro de 1985 pelo Congresso, como determinava a Constituição da ditadura, Tancredo não chegou a assumir o cargo. Internado na véspera da posse com problemas gastrointestinais, faleceu pouco mais de um mês depois após uma malsucedida série de cirurgias. Apesar de não ter exercido a presidência, seu nome figura na lista oficial de chefes de Estado brasileiros.
} 
partido, batizado Rede Sustentabilidade, que viabilizasse uma nova candidatura à eleição presidencial, surpreendeu o mundo político ao anunciar sua filiação ao PSB. Tornou-se candidata à vice-presidência na chapa do governador de Pernambuco, Eduardo Campos. Com a morte de Campos em um desastre aéreo em Santos (SP), em 13 de agosto de 2014, Marina foi escolhida pelo PSB como candidata à presidência, tendo Beto Albuquerque, quadro do partido no Rio Grande do Sul, como companheiro de chapa.

Luciana Genro (1971-), outra política saída dos quadros do PT, é filha do exgovernador petista do Rio Grande do Sul Tarso Genro. Iniciou a carreira política no movimento estudantil. Deputada estadual (1995-2002) e federal (2003-10), rompeu com o PT em 2003, por discordar da política de alianças do partido, e filiou-se ao Partido Socialismo e Liberdade (PSOL), de oposição de esquerda ao governo. O professor e sindicalista Jorge Paz, do mesmo partido, foi seu candidato à vice-presidência.

É impossível tratar da campanha eleitoral de 2014 sem acrescentar os dados biográficos de Eduardo Campos (1965-2014), candidato do PSB morto durante a campanha. Neto do ex-governador de Pernambuco Miguel Arraes (1916-2005), de quem foi chefe de gabinete e secretário, Campos foi eleito deputado estadual (1991-95) e federal (1995-2007) pelo mesmo estado. Ministro da Ciência e Tecnologia de Lula (2004-05), elegeu-se governador de Pernambuco em 2006, numa disputa contra o candidato do PT, Humberto Costa. Assumindo um discurso de oposição moderada ao governo, Campos apresentou-se à eleição de 2014 como candidato da "terceira via", alternativa à polarização PT-PSDB que dominou os pleitos presidenciais desde 1994.

\subsubsection{Cronologia da campanha eleitoral}

\section{3}

Junho - Manifestações em todo o país durante a Copa das Confederações (torneio internacional de futebol preparatório para a Copa do Mundo), cujo estopim foram protestos em São Paulo contra o aumento das passagens de ônibus. 
3 de outubro - O Tribunal Superior Eleitoral (TSE) nega registro à Rede, partido que Marina Silva tentava fundar, por falta de cerca de 50 mil das 492 mil assinaturas válidas necessárias para a criação da legenda.

5 de outubro - Marina Silva anuncia, em evento com o ex-governador de Pernambuco Eduardo Campos, sua filiação ao Partido Socialista Brasileiro (PSB).

10 de outubro - O PSB anuncia Campos como candidato à presidência.

19 de novembro - O Partido da Social Democracia Brasileira (PSDB) confirma Aécio Neves, senador por Minas Gerais, como seu candidato. O ex-governador de São Paulo José Serra ainda alimentava esperanças de ser candidato.

\section{4}

17 de março - Início da fase pública da Operação Lava Jato, com a prisão do doleiro Alberto Youssef e outras 16 pessoas em sete estados.

14 de abril - O PSB confirma Marina Silva como candidata à vice-presidência na chapa de Eduardo Campos.

2 de maio - Convenção do PT ratifica Dilma Rousseff como candidata à reeleição, sepultando um movimento em favor da candidatura do ex-presidente Lula.

12 de junho - A presidente Dilma Rousseff é xingada em coro por torcedores antes do jogo de abertura da Copa do Mundo, em São Paulo.

13 de agosto - Eduardo Campos e outras seis pessoas morrem em acidente aéreo em Santos (SP).

16 de agosto - O PSB oficializa Marina Silva como sua nova candidata.

19 de agosto - Início do horário eleitoral gratuito no rádio e na televisão.

26 de agosto - Primeiro de cinco debates televisivos entre os candidatos, na TV Bandeirantes (os demais ocorreram no SBT e nas TVs Aparecida, Record e Globo). As emissoras foram autorizadas a convidar apenas os sete nomes com mais "intenções de voto" nas pesquisas. 
5 de outubro - Primeiro turno das eleições. Dilma, com 41,6\% dos votos válidos, e Aécio, com 33,6\%, se qualificam para o segundo turno. Marina obtém 21,3\%, e Luciana Genro, $1,6 \%$.

23 de outubro - A revista Veja chega às bancas com a capa "Eles sabiam de tudo", em que o doleiro Alberto Youssef acusaria Dilma e Lula de terem conhecimento do esquema de corrupção na Petrobras.

24 de outubro - Último de quatro debates televisivos entre Aécio e Dilma, na TV Globo (os anteriores ocorreram nas TVs Bandeirantes, SBT e Record).

26 de outubro - Dilma Rousseff é reeleita com 51,6\% dos votos válidos.

\subsubsection{Números das pesquisas eleitorais}

Apresentamos a seguir os resultados das pesquisas de opinião de duas grandes empresas de pesquisa brasileiras, Ibope e Datafolha, relativos à campanha eleitoral de 2014. Diversas outras empresas realizaram pesquisas nacionais ${ }^{46}$, mas nos restringimos a estes dois por serem, de longe, aqueles que mais serviram como referência para os principais veículos de comunicação - por exemplo, em seu artigo de $1^{\circ}$ de outubro de 2014 Merval Pereira os qualifica como "os dois institutos de opinião mais acreditados pela opinião pública”.

Para salientar o caráter estável das pesquisas até o acidente aéreo que matou Campos, decidimos iniciar a série temporal de análises entre fevereiro e março de 2014, quando as principais candidaturas já estavam definidas, embora as convenções partidárias só tenham ocorrido entre maio e junho, obedecendo ao calendário previsto na legislação eleitoral. Entre o registro da pesquisa, a realização das entrevistas e sua publicação chega a transcorrer mais de uma semana: para os fins destes gráficos, considerou-se como data da pesquisa aquela do encerramento das entrevistas.

Os Gráficos 1 e 2 apresentam apenas os números dos três candidatos que viriam a ser os mais votados (Dilma, Aécio e Campos/Marina) apenas por uma preocupação de clareza, e não por negligência aos demais candidatos. Importa saber, em relação a estes,

\footnotetext{
${ }^{46}$ Os mais citados pelos meios de comunicação, além dos dois já mencionados, foram: Vox Populi, Sensus, MDA, Paraná Pesquisas e Verità.
} 
que alguns atingiram índices não desprezíveis ao longo da campanha: o Pastor Everaldo, do Partido Social Cristão (PSC), chegou a ter $4 \%$ das intenções de voto nas pesquisas do Datafolha de 5 de junho e 2 de julho, e $3 \%$ nos levantamentos do Ibope entre março e agosto. José Maria, do PSTU ((Partido Socialista dos Trabalhadores Unificado), chegou a registrar 2\% das intenções de voto na pesquisa Datafolha de 2 de julho. Os demais candidatos não chegaram em nenhum momento a ter mais de $1 \%$ das intenções de voto em nenhum dos dois levantamentos.

As características mais notáveis dos Gráficos 1 e 2, como se verá, são a rápida "ascensão" e "queda" de Marina Silva e a abrupta "subida" de Aécio Neves nos dias finais da campanha. A rapidez dessas oscilações fica ainda mais evidente pelo fato de os gráficos respeitarem rigorosamente a escala temporal, o que é raramente o caso nos infográficos publicados pelos jornais. 


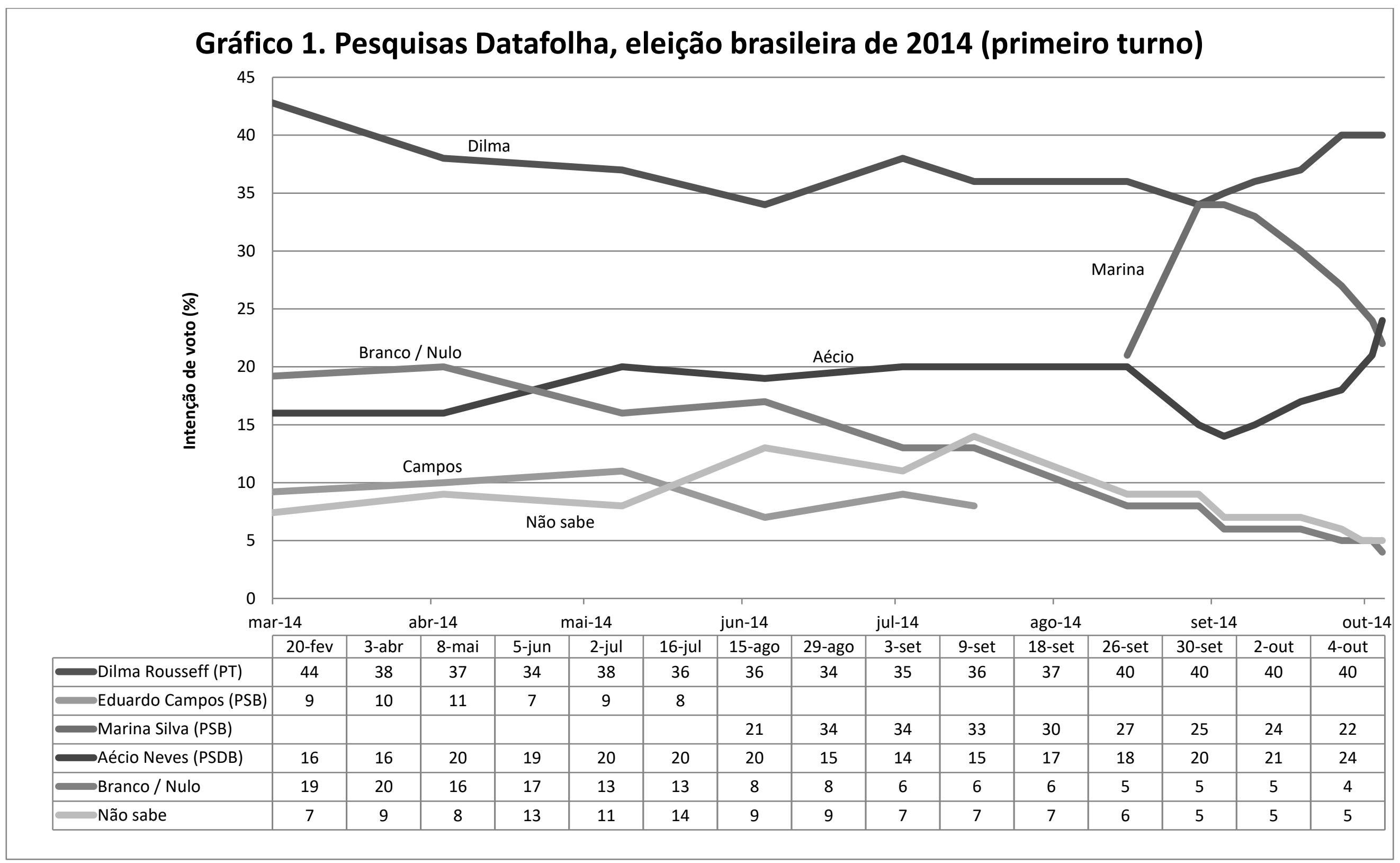




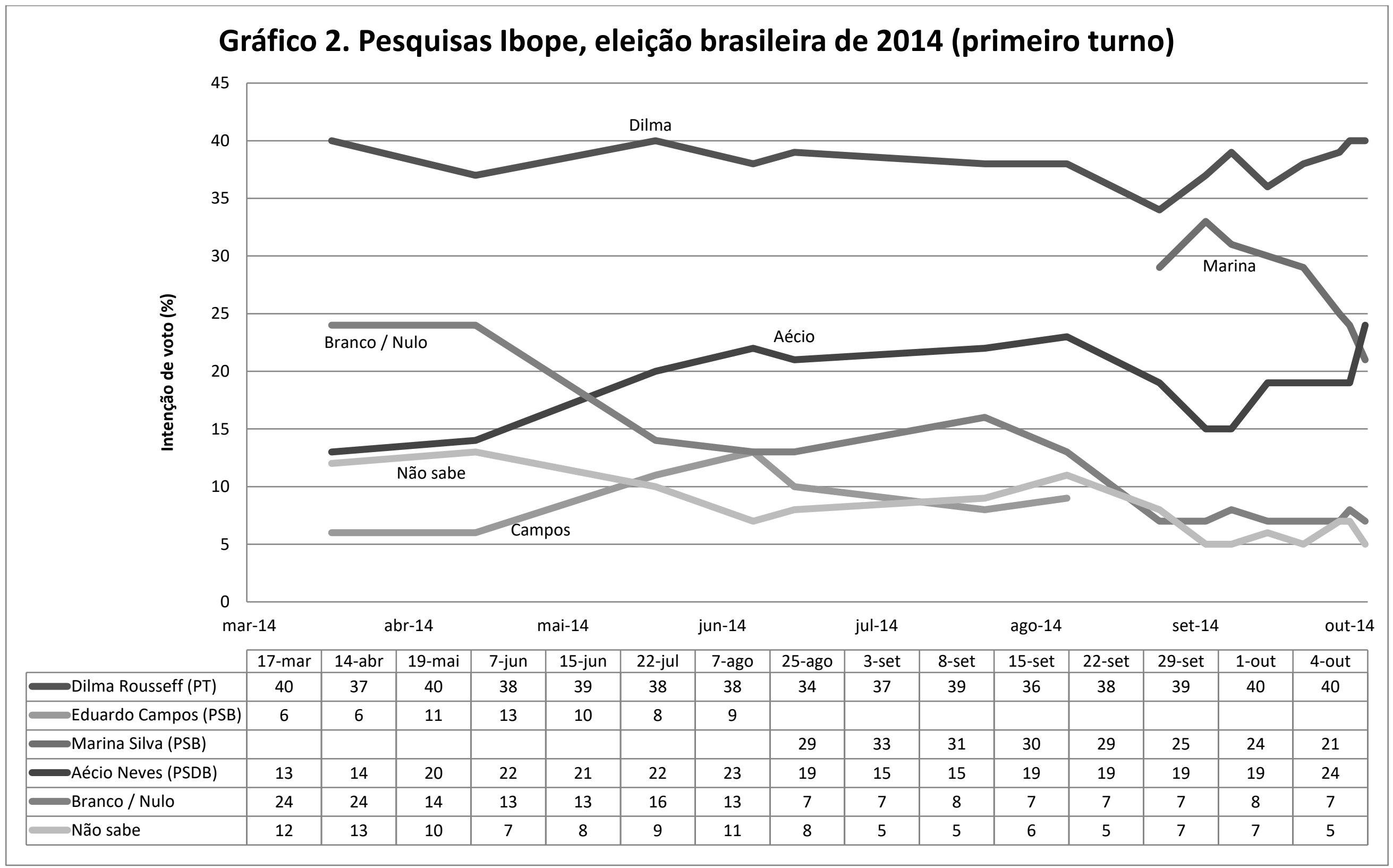




\subsubsection{A eleição presidencial argentina de 2015}

\subsubsection{Os candidatos}

A eleição presidencial de 2015 foi a oitava desde o fim da ditadura militar de 1976-83 e a readoção da Constituição em vigor, de 1853 (os pleitos anteriores ocorreram em 1983, 1989, 1994, 1999, 2003, 2007 e 2011), o que representa, de modo análogo ao verificado no Brasil, um período inédito de continuidade democrática na Argentina. ${ }^{47}$ No mesmo dia do primeiro turno da eleição presidencial foram realizadas as eleições para os governos de 11 das 24 unidades da Federação (23 províncias e a Cidade Autônoma de Buenos Aires); para a renovação de metade da Câmara dos Deputados e um terço do Senado da Nação; para as assembleias provinciais; e, pela primeira vez, para o preenchimento das 43 cadeiras argentinas no Parlamento do Mercosul (Parlasul).

A eleição presidencial opôs seis candidatos, selecionados inicialmente pelas alianças que compunham e ratificados em agosto de 2015 nas "eleições primárias" nacionais instituídas por lei em 2009.

Mauricio Macri (1959-), filho de um imigrante italiano e herdeiro de um grande grupo empresarial, figurou pela primeira vez no noticiário nacional em 1991, ao permanecer 12 dias em cativeiro, sequestrado por uma quadrilha composta por policiais federais. De 1995 a 2007, foi presidente do clube de futebol mais popular da Argentina, o Boca Juniors, e sua administração, bem-sucedida em termos esportivos (conquistou quatro vezes a Copa Libertadores, principal torneio da América do Sul), lustrou sua imagem de gestor. Em 2003 criou o partido Compromisso para a Mudança, como veículo para sua campanha ao governo da Cidade Autônoma de Buenos Aires (acabaria derrotado no segundo turno). Em 2005, junto com outro líder político, Ricardo López Murphy, fundou a aliança eleitoral Proposta Republicana (Pro), com a qual elegeu-se no mesmo ano deputado nacional, e em 2007, governador da Cidade de Buenos Aires, reelegendo-se em 2011 depois de cogitar a candidatura presidencial. Politicamente

\footnotetext{
${ }^{47}$ De forma análoga à verificada no Brasil entre 1894 e 1930, não se podem considerar como "livres" as nove eleições presidenciais argentinas entre 1862 e 1910, quando prevalecia o chamado voto cantado, ou de cabresto. Entre 1912 e 1976 ocorreram dez eleições presidenciais, mas o período foi entremeado por golpes de Estado $(1930,1943,1955,1962$ e 1966) que impediram a continuidade democrática.
} 
situa-se à direita do governo de Cristina Fernández. Sua companheira de chapa foi Gabriela Michetti, senadora pelo mesmo partido de Macri e ex-vice-governadora da Cidade Autônoma de Buenos Aires entre 2007 e 2009, na gestão do próprio Macri.

Daniel Scioli (1957-) foi o candidato da Frente para la Victoria, a aliança governista. Herdeiro de uma rede de lojas de eletrodomésticos (hoje extinta), notabilizou-se pela primeira vez aos 18 anos, como negociador da família quando o pai foi sequestrado por um grupo guerrilheiro marxista. Na juventude Scioli foi campeão de motonáutica, esporte em que perdeu o braço direito, em 1989, num acidente. Encerrada a carreira esportiva, elegeu-se deputado nacional em 1997, pelo Partido Justicialista, herdeiro da corrente peronista. Secretário de Turismo e Esporte durante os breves mandatos dos presidentes Adolfo Rodríguez Saá e Eduardo Duhalde, Scioli foi eleito vice-presidente da República na chapa de Néstor Kirchner, em 2003. Em 2007, elegeuse governador da província de Buenos Aires, cargo considerado o politicamente mais importante depois da presidência da República. Em 2011, foi reeleito. Em 2015, foi escolhido candidato à presidência, com o apoio da presidente Cristina Fernández, viúva de Néstor Kirchner. Representou o peronismo mais à esquerda. Seu compañero de fórmula (candidato a vice) foi Carlos Zannini, ex-deputado e secretário legal e técnico da Presidência (cargo com status de ministro) tanto no governo de Cristina quanto no de Néstor Kirchner.

Sergio Massa (1972-) apresentou-se como candidato da "terceira via". Começou a carreira política em um partido conservador, a UCéDé, tendo sido atraído para as fileiras do peronismo "de direita" durante a presidência (1989-99) de Carlos Menem. Afilhado político do sogro, o líder peronista "Pato" Galmarini (ligado a Menem), Massa foi diretor da Seguridade Social argentina (2002-07) e elegeu-se intendente (prefeito) da cidade de Tigre (2007). Nomeado chefe de gabinete do ministério de Cristina Fernández (2008), rompeu com o governo no ano seguinte, por uma disputa entre listas partidárias divergentes no seio do peronismo, reassumindo a prefeitura de Tigre. Massa reuniu um grupo de prefeitos dissidentes do kirchnerismo na aliança Frente Renovadora, pela qual foi eleito deputado nacional em 2013 e escolhido candidato à presidência em 2015. Seu candidato a vice, também da Frente Renovadora, foi Gustavo Sáenz, prefeito eleito da cidade de Salta. 
Nicolás del Caño (1980-), candidato da Frente de Esquerda, surpreendeu ao eleger-se deputado nacional pelo Partido dos Trabalhadores Socialistas (PTS) na província de Mendoza, em 2013. Nas eleições primárias de agosto de 2014, obteve a indicação de sua aliança ao superar por pequena margem o líder do Partido Operário, Jorge Altamira. Sua companheira de chapa foi a deputada Myriam Bregman.

Margarita Stolbizer (1955-), advogada, foi a candidata da aliança Progressistas, de centro-esquerda. Iniciou a militância política na tradicional União Cívica Radical. Em 2007, por discordar da candidatura de Roberto Lavagna à presidência, rompeu com o partido e fundou o GEN (Geração para um Encontro Nacional). Em 2007 e 2011, ficou, respectivamente, em segundo e terceiro lugar nas eleições para o governo da província de Buenos Aires, vencidas nos dois casos, por ampla margem, por Daniel Scioli. Seu candidato a vice foi o sindicalista Miguel Ángel Olaviaga.

Adolfo Rodríguez Saá (1947-) foi presidente interino da Argentina durante uma semana de dezembro de 2001, eleito pelo Congresso em meio ao conturbado período de crise vivido pelo país naquele ano. Fez carreira no Partido Justicialista (peronista), tendo governado a província de Santa Fé durante 18 anos (1983-2001). Foi deputado nacional (2003-05) e é senador desde 2005. Em 2003, foi candidato à presidência, derrotado por outras duas chapas peronistas, as de Carlos Menem e Néstor Kirchner. ${ }^{48}$ Representa uma ala não-kirchnerista do peronismo. Sua companheira de chapa foi a senadora peronista Liliana Negre de Alonso.

\subsubsection{Cronologia da campanha eleitoral}

\section{5}

18 de janeiro - É encontrado morto o procurador Alberto Nisman, que denunciara suposto conluio entre a presidente Cristina Fernández e o Irã para abafar a investigação do atentado a bomba de 1994 contra a Associação Mútua Israelita Argentina, que matou 85 pessoas em Buenos Aires. A investigação não esclareceu se a morte de Nisman foi homicídio ou suicídio.

\footnotetext{
48 Pelas regras eleitorais argentinas então vigentes a mesma corrente política podia lançar diferentes candidatos ao mesmo cargo, na mesma eleição, por alianças diferentes.
} 
26 de abril - Eleição interna do partido PRO confirma a pré-candidatura de Mauricio Macri, governador da Cidade Autônoma de Buenos Aires, pela aliança Cambiemos ("Mudemos").

10 de junho - Sergio Massa, do partido Frente Renovador e da aliança Unidos por uma Nova Alternativa (UNA), anuncia sua pré-candidatura à presidência.

18 de junho - A Frente para a Victoria (FPV) confirma que Daniel Scioli, governador da província de Buenos Aires, será o único candidato da aliança nas primárias de agosto.

9 de agosto - Realização das PASO (Primárias Abertas, Simultâneas e Obrigatórias). Elas ratificam, entre outras, as candidaturas de Scioli (candidato único da FPV), Macri (81\% dos votos dentro da primária da frente Cambiemos) e Massa $(69,6 \%$ dos votos da UNA).

23 de agosto - Eleições provinciais na província de Tucumán. A vitória de Juan Luis Manzur, da governista FPV, com 51,6\% dos votos, ensejaria acusações de fraude.

4 de outubro - Primeiro debate presidencial televisivo da história argentina. Dos seis candidatos, apenas Scioli, líder das pesquisas, não compareceu.

25 de outubro - Primeiro turno da eleição. Daniel Scioli obtém 37,1\% dos votos, e Mauricio Macri, 34,2\%. Sergio Massa fica em terceiro lugar, com 21,4\%.

15 de novembro - Debate televisivo entre Scioli e Macri, transmitido por diversos canais de TV paga e aberta e pela internet. ${ }^{49}$

22 de novembro - Segundo turno. Macri vence com 51,4\% dos votos válidos.

\subsubsection{Números das pesquisas eleitorais}

Encontramos maior dificuldade na escolha das empresas de pesquisa cujos números apresentaríamos os Gráficos 3 e 4. Isso se deve a profundas diferenças no

\footnotetext{
${ }^{49}$ Segundo o instituto Kantar Ibope Media, o debate teve audiência televisiva de $54,75 \%$ e foi assistido por 4,1 milhões de argentinos. Essa medição não inclui a audiência de internet. A título de comparação, a final da Copa do Mundo de futebol de 2014, em que a Argentina enfrentou a Alemanha, teve audiência de 52,77\%, segundo o mesmo instituto (CRETTAZ, 2014).
} 
ambiente dos levantamentos eleitorais na Argentina, em relação ao Brasil. Na Argentina, muitos dos proprietários das empresas de pesquisa, frequentemente chamados de consultores ou consultoras, têm relações próximas com determinados políticos ou partidos. Esses vínculos são conhecidos de pelo menos uma parte do público e debatidos pela imprensa e pela academia (VOMMARO, 2008). Naturalmente, levam a constantes questionamentos da precisão de seus números. Optamos por aqueles divulgados pelas consultoras que trabalham para os dois diários de maior circulação do país: Poliarquía (La Nación) e Management \& Fit (Clarín). Embora os dois jornais fossem de oposição ao governo kirchnerista, as pesquisas que publicaram na campanha do primeiro turno do pleito de 2015 não podem ser acusadas de viés oposicionista, ao contrário: nenhuma delas previu que seria tão apertada margem de votos (menos de três pontos percentuais) entre o candidato do governo, Daniel Scioli, o mais votado no primeiro turno, e o segundo colocado, Mauricio Macri.

Não são apresentados os números dos demais candidatos, nem os de indecisos e votos brancos e nulos, em razão da grande variação na forma de apresentação dos números na imprensa argentina (ora até a primeira casa decimal, ora arredondados até o número inteiro mais próximo; ora considerando apenas os votos válidos; ora levando em conta os indecisos; e às vezes sem indicar o número de entrevistados que se recusaram a responder), o que dificultou a sistematização desses dados.

No próximo capítulo enunciaremos os referenciais teóricos que serão utilizados como ferramenta de análise. Esses referenciais se inspiram, em particular, naqueles empregados por Guazina (2011) na análise da cobertura do Jornal Nacional no escândalo do Mensalão. Eles combinam o recurso à sociologia de Bourdieu e seu conceito de "campo" aos conceitos de agendamento e enquadramento tais como os entendem os teóricos da comunicação. 


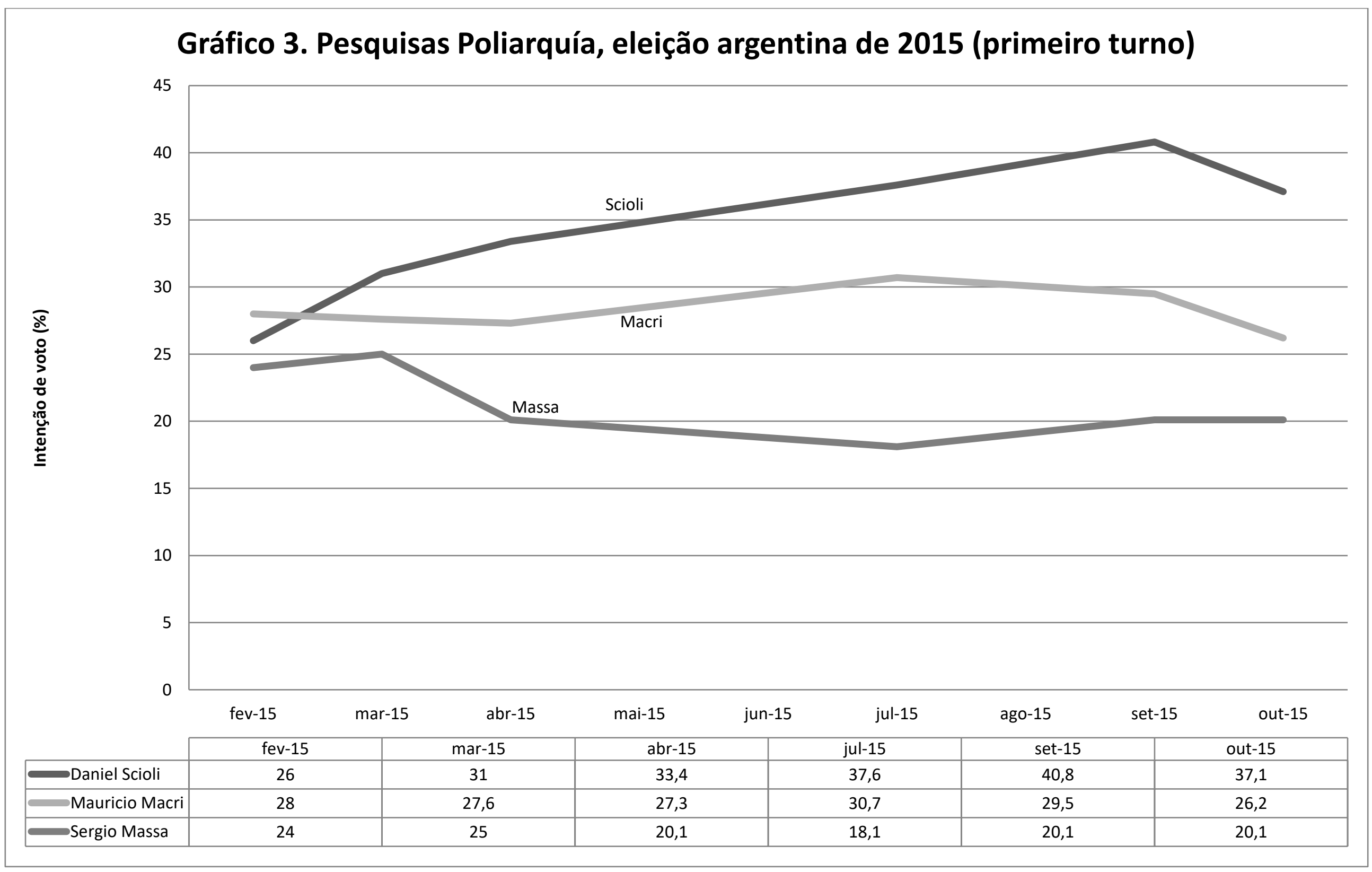




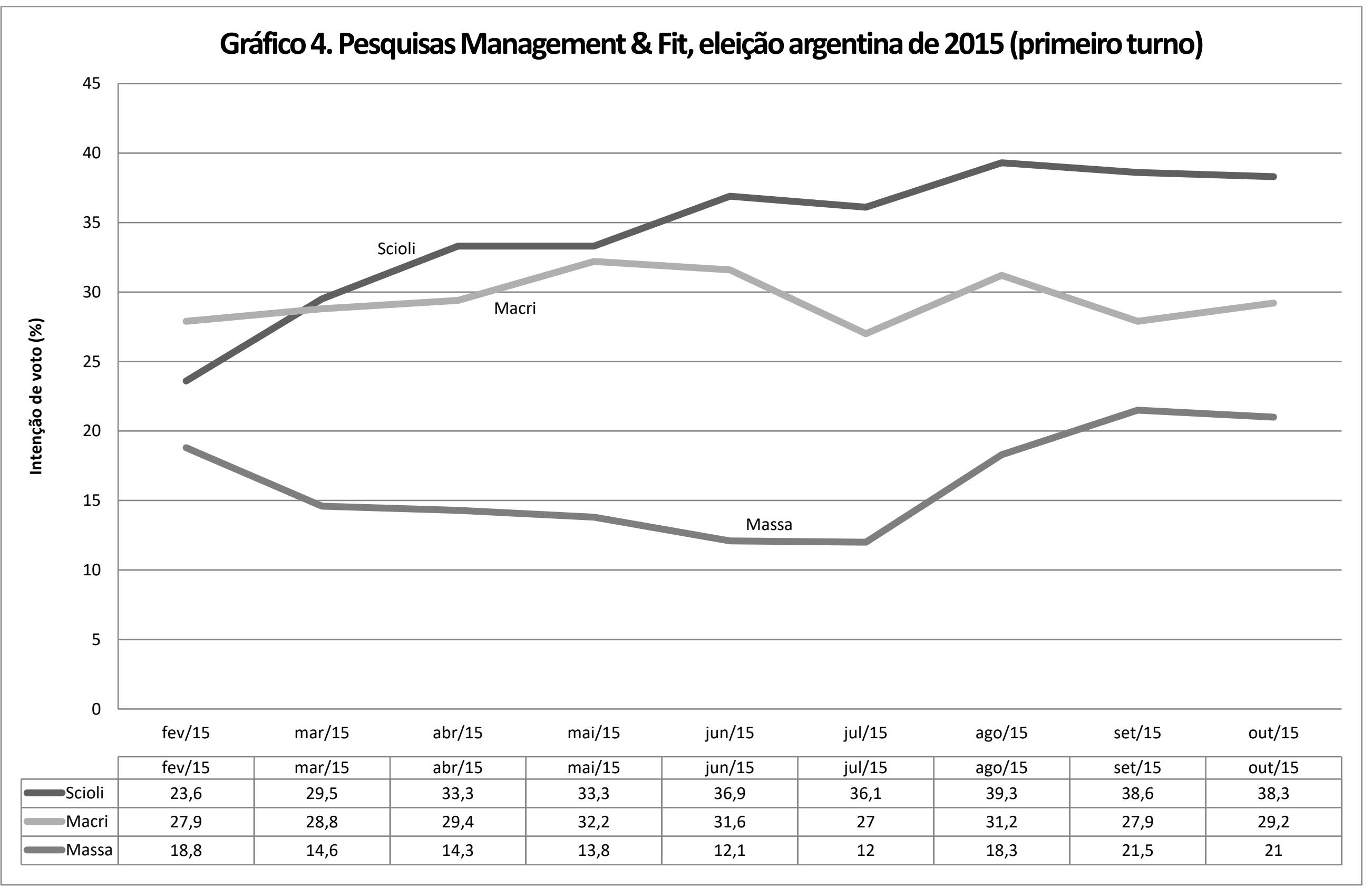




\section{Referenciais teóricos}

\subsection{Bourdieu, o conceito de campo e a "opinião pública"}

Logo no início de seu clássico ensaio "L'opinion publique n'existe pas", Bourdieu (1973) faz uma ressalva que este estudo encampa integralmente, a de que não faz sentido "denunciar de maneira mecânica e fácil as pesquisas de opinião". Bourdieu não está preocupado em esmiuçar (ainda que elas existam) as fragilidades técnicas das pesquisas como instrumento de aferição de uma suposta vontade popular. Reconhece até que "no estado atual dos meios utilizados" naquela época, as empresas que produziam pesquisas conseguiam formar amostragens representativas do universo pesquisado. A intenção de Bourdieu era, isso sim, resumindo-a de forma grosseira, analisar a própria ideia de que exista algo que se possa chamar de opinião pública que possa ser pesquisada.

A ciência da realização das pesquisas ainda estava na infância na década de 1970, mas sua onipresença na cobertura jornalística já justificava a atenção do sociólogo francês. Quase meio século depois, suas observações nada perderam da validade, resumidas neste trecho de seu trabalho:

Toda pesquisa de opinião pressupõe que todo mundo pode ter uma opinião; ou, em outras palavras, que a produção de uma opinião está ao alcance de todos. Sob pena de ferir um sentimento ingenuamente democrático, vou contestar esse postulado inicial. Segundo postulado: pressupõe-se que todas as opiniões se equivalem. Acredito que seja possível demonstrar que não é bem assim, e que o fato de empilhar opiniões que não têm a mesma força real conduz à produção de artefatos desprovidos de sentido. Terceiro postulado implícito: no simples fato de se fazer a mesma pergunta a todo mundo encontra-se implícita a hipótese de que há um consenso sobre os problemas; em outras palavras, que há uma concordância em relação às perguntas que merecem ser feitas. Esses três postulados acarretam, parece-me, toda uma série de distorções que são observados até mesmo quando todas as condições de rigor metodológico foram preenchidas na coleta e análise dos dados. (BOURDIEU, 1973, p. 1292)

Pode-se argumentar que numa pesquisa de intenção de voto não se encontram presentes os problemas inerentes aos postulados que Bourdieu menciona: afinal, escolher um candidato está ao alcance de todos os eleitores; uma eleição nada mais é 
que o "empilhamento" de opiniões que se equivalem - um eleitor, um voto -, já que diante da urna desaparecem todas as subjetividades que levam à escolha de um candidato, cristalizadas na digitação de um número; e que não há controvérsia em relação à pergunta a ser feita numa pesquisa eleitoral, uma vez que seu objetivo inambíguo é o de determinar as preferências com vistas a um pleito futuro, tenha este uma data determinada ou não.

Parece-nos, porém, que seria enganoso rechaçar sob esse argumento as questões levantadas por Bourdieu. Uma pesquisa de intenção de voto não é o mesmo que uma eleição; se é verdade que todos os eleitores se equivalem dentro da cabine eleitoral, não se pode dizer o mesmo antes da eleição. Isto não quer dizer que a opinião de um eleitor "alienado" valha "menos" que a de um eleitor "consciente" ou "engajado": simplesmente os cidadãos ainda não foram chamados a decidir e o "evento eleição" não passa de uma abstração mais ou menos distante. Além disso, o grau de envolvimento dos eleitores com o debate político varia permanentemente; e a decisão de indagar a uma amostra do eleitorado, em determinado momento, suas intenções de voto implica, como postula Bourdieu, uma suposta concordância em relação à relevância da pergunta.

É possível encarar as pesquisas eleitorais, e o uso que delas é feito na cobertura de uma campanha, de um ponto de vista puramente fenomenológico: os pesquisadores entrevistam os eleitores, divulgam os resultados dessas entrevistas, os jornalistas elaboram a partir desses resultados seus textos analíticos, e os cidadãos, de posse das informações fornecidas pelas pesquisas, pelas análises dos jornalistas e por diversas outras fontes, fazem sua escolha em plena liberdade.

Essa interpretação da realidade, porém, é insatisfatória. Para elaborar uma alternativa, que nos permita enxergar além do imediatamente visível, é preciso dotar-se de instrumentos adequados. Um desses possíveis instrumentos é aquele que nos permita interpretar a relação entre pesquisadores, jornalistas e público como uma relação de poder. Desse ponto de vista, a sociologia pode fornecer as ferramentas necessárias para entender essa relação. Na obra de Bourdieu encontram-se elementos que nos auxiliam a desvelar esses fios muitas vezes invisíveis, pois, em suas palavras, "deve-se saber descobrir [o poder] onde ele menos se faz visível, onde ele é mais perfeitamente desconhecido, logo reconhecido: o poder simbólico é, de fato, esse poder invisível que só pode ser exercido com a cumplicidade daqueles que não querem saber que a ele estão 
sujeitos ou mesmo que o exercem" (BOURDIEU, 1977, p. 405). Quando Bourdieu fala em poder "desconhecido", refere-se ao desconhecimento de que ele é arbitrário (p. 406).

Como arma para a reflexão, Bourdieu propõe em sua obra o conceito de campo, uma abstração que traz consigo a possibilidade de aplicar a diferentes universos - no caso desta pesquisa, o jornalismo, as ciências sociais e a política - "modelos baseados na hipótese de que existem homologias estruturais e funcionais" entre esses universos (BOURDIEU, 1989, p. 66-7). Os campos são microcosmos relativamente autônomos de relações específicas, regidos ao mesmo tempo por certas regras universais, comuns a todos os campos, e por regras próprias, que reafirmam a autonomia de cada campo.

O campo é útil para orientar a reflexão sobre os papéis exercidos por jornalistas, políticos e cientistas políticos na construção da realidade política. O que interessa a Bourdieu, porém, não é somente o campo, mas a estrutura de relações objetivas dos agentes dentro de um campo, e dos campos entre si. É impossível entender, na visão de Bourdieu, a produção de um agente no campo jornalístico (como os comentaristas políticos, ao analisar as pesquisas eleitorais) sem conhecer a posição que ele ocupa nesse campo, ou seja, seu lugar de fala.

Bourdieu (2005) parte de um evento que já se tornou uma instituição na política da França (assim como em outros países): a soirée électorale, a noite eleitoral na televisão. Nela, os principais canais põem lado a lado em seus estúdios jornalistas, políticos e cientistas sociais para discutir em tempo real as pesquisas de boca-de-urna e o resultado das eleições à medida que avança a apuração. É fácil traçar uma analogia com o que ocorre na cobertura eleitoral brasileira, em que os jornalistas recorrem à "autoridade" dos cientistas políticos, especialistas na análise das pesquisas e das eleições. Bourdieu reflete sobre a relação entre os três campos, representada na soirée électorale. Quando o cientista político se dirige ao jornalista, mais que um diálogo entre indivíduos, é o campo das ciências sociais que se relaciona com o do jornalismo. É uma relação de poder, em que cada um dispõe de suas armas: o cientista político, da autoridade que seu campo lhe oferece, e da qual o jornalista precisa; e o jornalista, do acesso ao público que só ele pode conceder ao cientista político, que dele precisa para reafirmar sua autoridade (BOURDIEU, 2005). 
Aplicando o conceito de Bourdieu, por exemplo, ao processo de consolidação do Ibope, abordado na Introdução deste trabalho, podemos identificar no esforço de propaganda de Auricélio Penteado e sua empresa, nos anos 1940, o reconhecimento da dominação simbólica do campo jornalístico na construção da imagem, junto ao público, das pesquisas de opinião como instituição; ao passo que, na deferência com que os meios de comunicação progressivamente trataram a cientificidade dos levantamentos do Ibope, é possível discernir o apelo do campo jornalístico ao campo das ciências sociais na corroboração de suas teses.

Inúmeros campos fazem uso das pesquisas. Em muitos casos, elas são praticamente o único indício existente para jogar alguma luz sobre determinadas características de uma sociedade: por exemplo, para que se possa ter alguma ideia das tendências do eleitorado em um determinado momento do passado, as pesquisas podem ser fonte valiosa de informações. ${ }^{50}$ Embora nem sempre se conheçam as condições em que foram realizados esses levantamentos, e eles estejam sujeitos a erros de amostragem ou de computação dos números, são frequentemente a melhor aproximação possível da realidade. É por essa, entre outras razões, que Bourdieu acerta ao ignorar o debate sobre a boa-fé dos pesquisadores ou sobre o fundamento científico dos levantamentos baseados em dados amostrais, e se dedica a mostrar como se produz a ideia da existência de uma "opinião pública" útil para determinadas construções da realidade.

O conceito de campo nos ajudará a compreender o lugar de fala dos colunistas dos veículos de comunicação e a forma como eles intervêm no processo eleitoral, com suas análises a partir dos números das pesquisas.

\subsection{Goffman, Entman e o enquadramento}

Metáforas futebolísticas figuram constantemente no discurso do brasileiro, seja esse discurso político, jornalístico ou até acadêmico. Porém é ao canadense Goffman que tomamos emprestada uma analogia desportiva que se aplica adequadamente ao caso

\footnotetext{
${ }^{50}$ Um exemplo claro se encontra em Lavareda (1999), que, somente graças à existência de uma pesquisa Ibope realizada em 1964 em oito capitais (e possivelmente não divulgada na época), pôde afirmar que Juscelino Kubitschek era o candidato mais cotado para a eleição presidencial de 1965. Essa eleição jamais ocorreria, adiada que foi para 1966 e por fim cancelada pelo Ato Institucional número 2, em outubro de 1965. Afora essa pesquisa, Lavareda talvez pudesse contar apenas com análises da imprensa e depoimentos de contemporâneos, sujeitos a todo tipo de viés.
} 
aqui em estudo, ao afirmar que "torcedores adversários em um jogo de futebol não vivenciam o 'mesmo' jogo" (GOFFMAN, 1986, p. 9). ${ }^{51}$ Uns podem considerar que o resultado da partida se deve ao mérito de um dos times; outros, que a culpa coube às falhas da equipe perdedora; e outros ainda podem atribuir o placar aos erros da arbitragem. Essa é, simplificadamente, a ideia por trás do conceito de framing, ou enquadramento: a de que um mesmo evento pode ser interpretado de maneira diferente por diferentes indivíduos.

Sociólogo de grande erudição e pioneiro no uso e desenvolvimento do conceito de framing, Goffman estava interessado em "isolar alguns dos enquadramentos básicos de compreensão, disponíveis em nossa sociedade, para extrair sentido dos acontecimentos" (p. 10). O autor vai buscar na filosofia a base de seu raciocínio, recorrendo, como ponto de partida, a um filósofo americano do século XIX, William James (1842-1910), à fenomenologia do alemão Edmund Husserl (1859-1938) e sua influência sobre o trabalho do cientista social austríaco Alfred Schütz (1899-1959). Todos esses pensadores, em seus respectivos campos de estudo, se debruçaram sobre a consciência humana e a forma como esta vivencia o mundo exterior.

Apoiado no trabalho desses autores, Goffman parte de uma constatação à primeira vista óbvia - a de que cada um de nós tem uma percepção singular do real -, mas que nos conduz a outras questões: se a interpretação da realidade é individual, e não existem duas percepções idênticas do mundo "concreto" a que pertencemos, com que universo deve o sociólogo trabalhar? Não se trata de negar a existência de um mundo real - aquele em que se dão as interações entre os indivíduos - e sim de determinar quais as regras, extraídas a partir das percepções (enquadramentos) individuais, que permitem a análise dessas interações. Goffman se propõe, justamente, a descobrir quais são essas regras.

Goffman não foi o primeiro a empregar o termo framing: ele mesmo atribui a primazia da proposição a Bateson (1955). Este parte da observação de dois macacos que, no zoológico de San Francisco, brincam de "brigar”. Ora, raciocina o autor, para que isso ocorra é preciso que ambos os primatas compartilhem o conhecimento de uma série de sinais que permitam aos dois saberem que se trata de

\footnotetext{
${ }^{51}$ A bem da verdade, o autor se refere ao futebol americano, e não ao futebol association, o que não invalida a analogia.
} 
uma brincadeira, e não de uma briga de verdade (por exemplo, mordisca-se o parceiro, em vez de se lhe cravar com força os dentes). Esse conhecimento em comum representa o frame sem o qual o jogo seria impossível.

Para explicar o termo frame, Bateson faz duas analogias com universos onde essa palavra é empregada em inglês - nas artes, a moldura (frame) que enquadra uma pintura; e na matemática, o sistema referencial de coordenadas que permite realizar medições. O próprio autor reconhece, porém, que a primeira analogia é concreta demais (uma vez que o enquadramento a que ele se refere é psicológico), ao passo que a segunda é excessivamente abstrata. Porém, afirma ele, a analogia da moldura, que influenciou a tradução portuguesa "enquadramento", é útil: "A moldura em torno de um quadro, se considerarmos essa moldura como uma mensagem que se propõe a ordenar ou organizar a percepção do observador, diz: 'Atente para aquilo que está dentro [da moldura], e não atente para aquilo que está fora."” (BATESON, 2006, p. 323).

Dono de um espírito eclético, Bateson transitou por várias áreas do conhecimento em sua obra. Ao tratar do framing, sua preocupação era investigar as causas dos distúrbios psiquiátricos então definidos como "esquizofrenia" (termo genérico hoje superado em favor de definições mais específicas, ainda que sujeitas a controvérsia). A hipótese de Bateson era que na origem da esquizofrenia estaria a incapacidade do indivíduo de compreender de forma operacional os sinais dos enquadramentos "corretos", isto é, tais como percebidos pela maioria dos demais indivíduos de uma sociedade.

Goffman emprega o termo frame em sentido semelhante ao de Bateson, embora seu interesse se atenha ao aspecto psicológico, e não psiquiátrico: são "as definições de uma situação construídas conforme princípios de organização que governam os acontecimentos - pelo menos os sociais - e nosso envolvimento subjetivo neles" (GOFFMAN, 1986, p. 10-1).

Goffman (1974) recorre a abundantes exemplos extraídos da imprensa - e chega a se desculpar por isso, ciente de que, como representação da realidade, o noticiário é uma fonte pobre para o pesquisador acadêmico, em razão de seu caráter anedótico. Considerando o quanto o enquadramento tem sido empregado, no campo da comunicação, no estudo do discurso dos meios noticiosos, é revelador citar a percepção sarcástica de Goffman (1986, p. 14) em relação às distorções da imprensa: "Nossa 
compreensão do mundo precede essas matérias, determinando aquelas que os repórteres vão selecionar e como aquelas que foram selecionadas serão contadas." As reportagens de "interesse humano", como se diz no jargão da profissão, explica Goffman, são caricaturas da realidade, por possuírem unidade, coerência, completude e carga dramática em grau que dificilmente seria encontrado no cotidiano. E assim são porque desempenham um papel específico, o de representar arquétipos da compreensão convencional do mundo, reforçando, em vez de enfraquecer, a crença do público no conjunto de regras - no enquadramento - que rege nossa interação social. Não é difícil enxergar nessa observação de Goffman uma abordagem precoce do enquadramento nos meios de comunicação.

A perspectiva de Goffman é psicológica; o próprio autor reconhece que, embora seu campo seja a sociologia, ao estudar o enquadramento está mais interessado na percepção do indivíduo que nos efeitos desta sobre a realidade social.

O conceito de enquadramento, porém, despertaria o interesse do campo da comunicação, por revelar-se útil na compreensão do papel dos meios noticiosos na vida política (REESE, GANDY e GRANT, 2001). Robert Entman, professor da Universidade Northwestern, no estado americano de Illinois, é o autor de estudos seminais nessa área, transpondo o conceito de framing para os estudos de comunicação. Em sua definição já clássica, “o framing envolve, essencialmente, seleção e saliência. Enquadrar significa selecionar alguns aspectos de uma realidade percebida e ressaltá-los em um texto comunicativo, de forma a promover uma determinada definição de um problema, interpretação causal, avaliação moral e/ou recomendação de tratamento para o aspecto descrito" (ENTMAN, 1993, p. 52).

Em seus trabalhos mais recentes, Entman (2004, p. 5) demonstra preocupação com um esvaziamento do conceito de framing, produto de seu uso generalizado, muitas vezes sem uma definição precisa. Segundo ele, o enquadramento "se tornou vulnerável a críticas, como um termo genérico que significa coisas ligeiramente distintas conforme o pesquisador que o emprega". Entman reconhece que, desde Goffman, o enquadramento tornou-se vítima do próprio sucesso: seu emprego nos mais diversos campos do conhecimento gerou uma fragmentação que passou a exigir esclarecimentos possibilitando uma compreensão melhor do termo. 
Para equacionar esse problema, Entman busca construir um modelo aplicável a toda pesquisa que envolva enquadramento. Como ponto de partida, ele classifica os enquadramentos em duas categorias: os substanciais e os processuais ${ }^{52}$. Os enquadramentos substanciais são definidos como aqueles onde a cobertura de eventos, questões ou atores políticos desempenha pelo menos duas de quatro funções básicas:

- Definição do problema (efeitos ou condições problemáticas);

- Identificação de causas (para o problema apresentado);

- Elaboração de uma avaliação ou julgamento moral;

- Endosso de soluções ou aprimoramentos.

O exemplo escolhido por Entman é a cobertura dos atentados terroristas de 11 de setembro de 2001, cujo enquadramento ele define conforme resumido na Tabela 10:

Tabela 10 - Funções e objetos dos enquadramentos noticiosos, segundo Entman

\begin{tabular}{|c|c|c|c|}
\hline $\begin{array}{c}\text { Função do } \\
\text { enquadramento }\end{array}$ & Questão: Guerra & $\begin{array}{l}\text { Evento: } 11 \text { de } \\
\text { Setembro }\end{array}$ & $\begin{array}{c}\text { Atores: Al-Qaeda e } \\
\text { Talibã }\end{array}$ \\
\hline Problema & $\begin{array}{c}\text { Necessidade de } \\
\text { destruir a Al-Qaeda }\end{array}$ & $\begin{array}{l}\text { Ato-surpresa de guerra } \\
\text { contra os EUA }\end{array}$ & Al-Qaeda e Talibã \\
\hline Causa & Atentados de $11 / 9$ & Terrorismo & $\begin{array}{c}\text { Ideologia, inveja dos } \\
\text { EUA }\end{array}$ \\
\hline Solução & $\begin{array}{l}\text { Mobilização de } \\
\text { recursos para a } \\
\text { guerra, apoio às } \\
\text { Forças Armadas } \\
\end{array}$ & Unidade, proteção & Guerra \\
\hline Avaliação & $\begin{array}{c}\text { Guerra prova EUA } \\
\text { unidos, eficientes, } \\
\text { morais }\end{array}$ & $\begin{array}{l}\text { Terroristas maus, } \\
\text { irracionais e } \\
\text { competentes; } \\
\text { americanos inocentes }\end{array}$ & $\begin{array}{l}\text { Terroristas são maus, } \\
\text { opressores, fracos, } \\
\text { impopulares; EUA bons } \\
\text { e poderosos }\end{array}$ \\
\hline
\end{tabular}

O segundo tipo de enquadramento, que Entman batiza de processual, realiza avaliações da legitimidade dos atores políticos, com base em sua técnica, êxito e representatividade. Em outras palavras, é o enquadramento que se baseia mais no desempenho pessoal dos agentes políticos do que na essência das questões de que eles

\footnotetext{
${ }^{52}$ Entman toma emprestada à linguagem do Direito na língua inglesa a distinção entre substantive e procedural. Em português a terminologia opõe o Direito Material, que diz respeito à essência da controvérsia entre as partes, ao Direito Processual, que se refere às regras dentro das quais se trava essa controvérsia. A rigor, isso recomendaria traduzir os conceitos de Entman como "enquadramento material" e "enquadramento processual", mas mantivemos aqui a tradução empregada em outros trabalhos.
} 
tratam - assim, para permanecer no exemplo do 11 de Setembro, discutir a competência de George W. Bush, então presidente dos EUA, desviaria a atenção de questões substantivas de política externa do governo americano. Neste trabalho trataremos apenas de enquadramentos que Entman define como substanciais.

O enquadramento se opera por meio do uso repetido e destacado de palavras e imagens que estimulem, no público receptor, o apoio a determinada posição em um conflito político. Ele age sobre os esquemas mentais que cada um de nós emprega para lidar com o conhecimento de questões diversas. Entman, mais uma vez, exemplifica com o 11 de Setembro: um esquema mental relacionado a esse acontecimento pode incluir o World Trade Center; os sequestradores dos aviões; Osama bin Laden; o corpo de bombeiros de Nova York; e o prefeito da cidade, Rudolph Giuliani, entre outros protagonistas.

O mecanismo de ação do enquadramento sobre os esquemas mentais do público foi batizado por Entman de modelo de ativação em cascata, em que as ideias se disseminam dentro de uma rede onde as fontes governamentais ocupam o "topo" e, em patamares sucessivos que incluem outras autoridades e a imprensa, os enquadramentos atingem o público (Entman está especificamente interessado em estudar como o governo americano influencia as percepções do público; por isso, sua "cascata" parte da Casa Branca). Esse processo, na visão de Entman, não é de mão única, e até mesmo o público, último degrau dessa cadeia, pode influenciar os demais atores. As pesquisas de opinião seriam, no modelo em cascata, uma forma de exercício dessa influência. Ao referir-se às pesquisas, Entman está pensando, sobretudo, nos índices de popularidade presidenciais, regularmente acompanhados nos Estados Unidos (como em outros países) pelas empresas de pesquisa e pelos meios de comunicação. Embora reconheça as limitações das pesquisas como instrumento de medição da "opinião pública", Entman é simpático a elas como "indicadores significativos das preferências da maioria" (ENTMAN, 2004, p. 127). Nesse aspecto discordamos de suas conclusões, por considerarmos que as pesquisas são um mecanismo de enquadramento utilizado pelos políticos e pelos meios de comunicação para influenciar o público, e não o contrário. Falaremos disto mais adiante, ao tratar dos enquadramentos das colunas analisadas.

D’Angelo e Kuypers (2010) apresentam o estado da arte na discussão sobre framing. Entre outros temas abordados pelos organizadores dessa compilação de 
artigos, estão a "guerra ao terror" levada a cabo pelos Estados Unidos após os atentados de 11 de setembro de 2001 e a cobertura do debate sobre mudanças climáticas e aquecimento global. Os autores não se limitam a discutir o papel dos veículos de comunicação tradicionais. Também abordam, por exemplo, a crescente influência dos blogueiros.

\subsection{Enquadramento, mídia e política no Brasil}

No Brasil, as pesquisas sobre os meios de comunicação têm se valido do enquadramento sob abordagens variadas. Porto (2005) situa o framing na perspectiva dos quatro "direitos culturais" do cidadão descritos por Murdock (1999): o direito à informação, o direito à experiência, o direito ao conhecimento e o direito à participação. Desses quatro direitos, Porto chama a atenção para o terceiro, o direito ao conhecimento. Segundo ele, o debate sobre o papel dos meios de comunicação dá muita ênfase ao direito à informação, mas pouco ao direito ao conhecimento. Em outras palavras, não há preocupação suficiente com o papel político dos meios de comunicação como fonte de contextualização, como "fonte de enquadramentos interpretativos que apresentam 'explicações' específicas de questões e acontecimentos politicamente relevantes". Estudando o papel do Jornal Nacional, da TV Globo, telejornal de maior audiência no Brasil, nas eleições de 2002, conclui que o debate sobre a economia brasileira não apresentou uma diversidade de vozes suficiente para proporcionar ao público o direito ao conhecimento, mesmo tendo satisfatoriamente atendido a necessidade de acesso à informação. Nesse sentido, operou-se um enquadramento que "restringe o leque de interpretações ao qual os eleitores são expostos" (PORTO, 2005, p. 141).

Lima e Guazina (2004) realizaram uma análise comparativa da cobertura do Jornal Nacional e do concorrente Jornal da Record nas eleições presidenciais de 1998. Concluíram que ambos os telejornais utilizaram enquadramentos oficialistas, favoráveis ao governo de Fernando Henrique Cardoso, então candidato à reeleição. Guazina (2011) aprofunda essa análise em estudos posteriores, o último deles sobre a cobertura do Jornal Nacional do Escândalo do Mensalão, em 2005, para classificá-la dentro do conceito de "cobertura adversária" (do inglês adversarial). $\mathrm{Na}$ sua definição, “enquadramentos são formas de organizar o pensamento, e expressam ideias 
organizadoras que revelam modelos de interpretação sobre a política. Estas ideias derivam, de um lado, dos valores compartilhados da subcultura e do ethos profissional, e de outro, dos valores associados à cultura política brasileira" (GUAZINA, 2011, p. 89).

Miguel e Biroli (2010) apontaram a homogeneidade de ponto de vista dos meios de comunicação de massa no Brasil como elemento de reprodução e perpetuação de uma interpretação estreita da democracia. "A mídia não se limita a refletir uma realidade que a cerca", afirmam os autores; "ela desempenha uma função ativa na reprodução de práticas sociais”. Lima (2006) analisa de que forma a concentração da propriedade da grande mídia nas mãos de poucos grupos influi na cobertura jornalística da política - por exemplo, no conluio entre empresários e políticos na atribuição de concessões de radiodifusão; e na ênfase em determinadas narrativas, privilegiando escândalos políticos prejudiciais a determinados partidos e omitindo aqueles prejudiciais a outros.

Como ocorre em outras áreas da sociedade, no âmbito latino-americano o Brasil não figura como exceção. Diversos estudos (TREJO DELARBRE, 2010; MÖNCKENBERG, 2014) se debruçaram sobre a concentração da propriedade dos meios de comunicação, impressos ou de radiodifusão, nos países da região. Trejo Delarbre aponta os grupos Clarín (Argentina), Globo (Brasil), Televisa (México) e Cisneros (Venezuela) como os de presença mais hegemônica no continente, todos atuando nas áreas de televisão aberta e por assinatura, rádio e (à exceção do grupo Cisneros) mídia impressa.

Dois dos grupos citados acima - Clarín e Globo - figuram neste trabalho, através dos colunistas dos principais jornais de cada corporação, Clarín e $O$ Globo. Os outros dois colunistas pertencem a grupos que, ainda que de menor alcance, também estão entre os hegemônicas em seus países - Grupo Estado, no Brasil; e La Nación S.A., na Argentina. Os quatro grupos, de linha editorial tradicionalmente conservadora, se encontravam ideologicamente na oposição no momento das eleições presidenciais brasileira de 2014 e argentina de 2015. 


\subsection{McCombs e Shaw e o agendamento}

Um artigo publicado na revista Public Opinion Quarterly em 1972 viria a ter profunda influência sobre os estudos de comunicação nas décadas seguintes. "The Agenda Setting Function of Mass Media", dos americanos Maxwell McCombs e Donald Shaw, apresentava um conceito, o de agenda-setting, traduzido em português ora como "agendamento", ora como "temário" ou "teoria da agenda", que abria uma nova perspectiva para a pesquisa do papel dos meios de comunicação de massa no cotidiano das sociedades democráticas.

McCombs e Shaw constataram a correlação existente entre os temas aos quais os meios de comunicação dão maior destaque e a importância atribuída pelo público a esses mesmos temas. A ideia de agendamento representava uma evolução dentro da investigação da função da imprensa como definidora da realidade. Walter Lippmann, no clássico Public Opinion (1922), postulava a influência da imprensa sobre a consciência do leitor como decisiva na formação daquilo que chamamos de "opinião pública". Os primeiros paradigmas relativos aos efeitos dos meios de comunicação postulavam um efeito "hipodérmico" desses meios, por analogia com uma seringa que "inocula" num público indefeso aquilo que o autor da mensagem deseja transmitir ao receptor.

A teoria hipodérmica foi superada, diante da constatação de que os efeitos dos meios de comunicação não são absolutos. $\mathrm{O}$ conceito de agendamento propiciava uma hipótese satisfatória, testável empiricamente, que permitia a sistematização de estudos capazes de gerar um corpus que fizesse avançar a pesquisa.

Críticas ao agendamento levaram McCombs a incorporar o enquadramento - e outro conceito relativamente recente dos estudos em comunicação, o de priming, ou "sugestionamento" - em sua teoria, como um nível à parte dentro do agendamento (McCOMBS et al., 1997; McCOMBS e GHANEM, 2001; McCOMBS, 2009). Entre outros estudos, ele cita o trabalho de George Comstock e Erica Scharrer (1999) sobre o papel da televisão na sociedade: "Conceitualmente, o priming e o framing são subespécies dos efeitos do agendamento, que influenciam a avaliação pública e a interpretação além da imputação de importância" (COMSTOCK e SCHARRER, apud McCOMBS, 2009). 
Outros autores tentaram conciliar agendamento e enquadramento, esclarecendo diferenças e pontos em comum entre os dois conceitos. Scheufele e Tewksbury (2007) retraçam o histórico dos dois termos e acrescentam, da mesma foram, o de priming, tal como proposto por Iyengar e Kinder (1987) e definido como "as mudanças nos padrões empregados pelo público para fazer avaliações políticas”.

Em artigo recente e provocador sobre o estado da arte do tema, Cacciatore, Scheufele e Iyengar (2015) discutem "a morte do enquadramento tal como o conhecemos": "Ambiguidades em torno de como conceituamos e, portanto, operacionalizamos o framing começaram a sobrepor-se a outros modelos de efeitos da mídia, a um ponto que se torna disfuncional", afirmam (CACCIATORE et al., 2015, p. 2). Os autores propõem que o campo da comunicação empregue o conceito de enquadramento de forma mais restrita.

Para Takeshita (1997), "as pesquisas sobre o agendamento e sobre o enquadramento se beneficiariam mutuamente, e ambas as perspectivas contribuirão para explorar a função definidora da realidade dos meios de comunicação". Acreditamos que uma convergência entre os conceitos de agendamento e enquadramento não só é possível, mas é útil para os estudos de comunicação. Este projeto aplicará ambos, considerando o agendamento como a seleção dos temas que ditarão o debate público, por parte daqueles que desejam influenciá-lo; e o enquadramento, a perspectiva específica em relação a cada tema da agenda, visando igualmente obter determinado efeito sobre a realidade social.

\subsection{Hallin, Mancini e os estudos comparativos}

É fácil entender as razões do êxito dos estudos comparativos como método de estudo nas ciências sociais. Uma das mais óbvias é a possibilidade de identificar conceitos universais, ou pelo menos que se apliquem a diferentes sociedades. No caso da pesquisa em comunicação, a comparação entre as realidades de diferentes países é fundamental, haja vista a impossibilidade de pensar a comunicação sem levar em conta as variações entre as condições do ambiente mediático de uma nação para outra.

Um trabalho pioneiro no trato dessa questão foi Four Theories of the Press, estudo publicado em 1956 pelos americanos Frederick Siebert, Theodore Peterson e 
Wilbur Schramm. A pergunta básica dos autores era: por que a imprensa soviética é tão diferente da americana, ou a argentina tão diferente da britânica? A melhor maneira de descobrir seria conhecer os sistemas em que se desenvolve a imprensa de cada país. Eles postulavam que "a imprensa sempre assume a forma e a coloração das estruturas políticas e sociais em que opera. (...) Entendemos que uma compreensão desses aspectos da sociedade é fundamental para qualquer compreensão sistemática da imprensa" (SIEBERT et alii, apud HALLIN e MANCINI, 2004, p. 1). Em linhas gerais, Siebert, Peterson e Schramm dividiram esses sistemas em autoritários, libertários, comunistas e socialmente responsáveis. Essa classificação, em que grosso modo o sistema mediático espelharia o sistema de governo de cada nação, sofria evidente influência do contexto de Guerra Fria. Embora tenha tido grande impacto sobre os estudos sobre comunicação, passou a exigir atualizações decorrentes de uma nova realidade geopolítica global e de suas próprias insuficiências como modelo.

$\mathrm{Na}$ última década, os estudos comparativos dos meios de comunicação contemporâneos foram influenciados pelo trabalho dos professores Daniel Hallin, da Universidade da Califórnia, e Paolo Mancini, da Universidade de Perugia, na Itália. Eles tentam progredir a partir das pegadas de Siebert, Peterson e Schramm. O modelo apresentado por Hallin e Mancini (2004) representou um avanço em relação às incipientes tentativas anteriores de criar categorias de análise que permitissem investigações comparativas dos meios de comunicação de diferentes países. Hallin e Mancini concordam com o pressuposto de seus precursores, mas discordam da forma como Siebert e seus colegas abordaram na prática a questão, concentrando-se, segundo essa crítica, mais nas questões ideológicas que na relação prática entre os sistemas mediáticos e os sistemas sociais.

O novo modelo proposto por Hallin e Mancini busca semelhanças entre países de acordo com uma série de critérios: a estrutura do mercado de meios de comunicação; o paralelismo político (ou seja, o grau de adesão dos veículos de comunicação à linha ideológica dos partidos); o grau de profissionalização do exercício do jornalismo; e o papel do Estado na estruturação do modelo de mídia (subsídios, censura, legislação etc.).

Da análise de 18 países da Europa e da América do Norte os autores extraíram três modelos de sistemas mediáticos: o modelo pluralista polarizado, associado aos 
países do Mediterrâneo (Espanha, França, Grécia, Itália e Portugal), onde a circulação dos jornais é relativamente baixa em relação à população, há uma intervenção acentuada do Estado e a profissionalização do jornalismo é menor; o modelo corporativo democrático, prevalente na Europa Central e do Norte (Alemanha, Áustria, Bélgica, Dinamarca, Finlândia, Holanda, Noruega, Suécia e Suíça), em que a intervenção do Estado pouco afeta a liberdade de imprensa, e o jornalismo é altamente profissionalizado; e o modelo liberal, dos países do Atlântico Norte (Canadá, Estados Unidos, Irlanda e Reino Unido), onde a imprensa quase não sofre interferência do Estado e prevalecem as leis do mercado (com exceções notáveis, como a BBC britânica).

Esses três modelos, esboçados acima de forma bastante ligeira, constituem uma boa grade de análise para estudos comparativos da mídia em boa parte do mundo, mas possuem limitações - a mais evidente delas o fato de se referirem apenas a países do mundo ocidental e do Hemisfério Norte, o que, de resto, é reconhecido pelos próprios autores. Em 2011, Hallin e Mancini retornaram ao tema, com a colaboração de estudiosos de todos os continentes. Albuquerque, um dos autores, expõe os aspectos em que o modelo de Hallin/Mancini se aplica ou não ao ambiente mediático brasileiro (HALLIN e MANCINI, 2011, p. 72-95; ALBUQUERQUE, 2012). Aponta, por exemplo, a dificuldade em encaixar o sistema brasileiro nos critérios de "paralelismo político" propostos por Hallin e Mancini, pois não se pode falar nem em independência absoluta nem em adesão total à linha dos partidos políticos. ${ }^{53}$

São evidentes os riscos da aplicação acrítica das categorias propostas por Hallin e Mancini a outras realidades que não as das nações desenvolvidas do Hemisfério Norte. Fizemos o exercício de definição de algumas dessas categorias, realizando adaptações que levam em conta as especificidades dos modelos argentino e brasileiro e as necessidades deste estudo, conforme pode ser observado na Tabela 11, abaixo.

\footnotetext{
${ }^{53}$ Cumpre não esquecer, porém, o papel desempenhado pela Rádio Nacional, pública (embora de modelo comercial), entre os anos 1930 e 1950, a que Albuquerque não faz referência em seu artigo.
} 
Tabela 11 - Características dos sistemas mediáticos brasileiro e argentino segundo os critérios de Hallin e Mancini

\begin{tabular}{|c|c|c|}
\hline Brasil & Argentina \\
\hline $\begin{array}{c}\text { Baixa circulação de jornais; } \\
\text { imprensa de elite de orientação } \\
\text { política }\end{array}$ & $\begin{array}{c}\text { Desenvolvimento } \\
\text { do mercado } \\
\text { mediático }\end{array}$ & $\begin{array}{c}\text { Baixa circulação de jornais; } \\
\text { imprensa de elite de orientação } \\
\text { política }\end{array}$ \\
\hline $\begin{array}{c}\text { Defesa da livre iniciativa; } \\
\text { desconfiança em relação às } \\
\text { instituições políticas; reação a } \\
\text { propostas de regulamentação }\end{array}$ & Paralelismo político & $\begin{array}{c}\text { Defesa da livre iniciativa; } \\
\text { desconfiança em relação às } \\
\text { instituições políticas; reação a } \\
\text { propostas de regulamentação }\end{array}$ \\
\hline $\begin{array}{c}\text { Baixa profissionalização; } \\
\text { instrumentalização }\end{array}$ & $\begin{array}{c}\text { Profissionalização } \\
\text { da profissão }\end{array}$ & $\begin{array}{c}\text { Baixa profissionalização; } \\
\text { instrumentalização }\end{array}$ \\
\hline $\begin{array}{c}\text { Predomínio do mercado; TV e rádios } \\
\text { públicas com influência baixa; } \\
\text { persistência de oligopólios surgidos } \\
\text { no período ditatorial }\end{array}$ & $\begin{array}{c}\text { Grau e natureza da } \\
\text { intervenção do } \\
\text { Estado no sistema } \\
\text { mediático }\end{array}$ & $\begin{array}{c}\text { Predomínio do mercado; TV e rádios } \\
\text { públicas com influência média; } \\
\text { persistência de oligopólios surgidos } \\
\text { no período ditatorial }\end{array}$ \\
\hline
\end{tabular}

Fonte: Elaboração própria a partir de HALLIN e MANCINI (2004); ALBUQUERQUE (2012); LIOTTI (2014).

Algumas das características da Tabela 11 - como a baixa circulação dos jornais $^{54}$, a baixa profissionalização e a instrumentalização ${ }^{55}$ da profissão de jornalista permitiriam classificar Brasil e Argentina dentro do modelo que Hallin e Mancini batizaram de "pluralista polarizado", ou "mediterrâneo", por ser característico de países da Europa Meridional (Espanha, França, Grécia, Itália, Portugal). Porém outros critérios, como o grau de intervenção do Estado, aproximam-nos mais do modelo "liberal" ou "do Atlântico Norte", em que o mercado dos meios de comunicação é regido pela liberdade de mercado. Na Argentina pode-se falar em um papel maior do Estado, seja por um peso maior da televisão pública (por razões históricas do processo de constituição das primeiras emissoras no país), seja em virtude da Ley de Medios de 2009, que impôs restrições à formação de oligopólios. Persiste, porém, um quadro geral de predomínio de um pequeno número de grupos privados (LIOTTI, 2014). Em que

\footnotetext{
${ }^{54}$ Segundo os institutos verificadores de circulação dos dois países, a circulação paga dos vinte maiores diários argentinos, em 2016, somava 700 mil exemplares diários (INSTITUTO VERIFICADOR DE CIRCULACIONES, 2016), ante uma população estimada em 43 milhões de pessoas, ou seja, aproximadamente 1 exemplar para cada 60 habitantes; a dos vinte maiores diários brasileiros, em 2015, 2,1 milhões de exemplares diários (ASSOCIAÇÃO NACIONAL DE JORNAIS, 2015), ante uma população estimada em 208 milhões de pessoas, ou seja, aproximadamente 1 exemplar para cada 100 habitantes.

${ }^{55}$ Hallin e Mancini (p. 33) reconhecem a ambiguidade desses termos, no que se refere ao jornalismo, e tentam restringir sua definição. Por "profissionalização" entenda-se a autonomia formal do jornalismo como profissão, mas também sua autonomia em relação ao campo político, no sentido de "campo" de Bourdieu. Por "instrumentalização" os autores entendem o controle da mídia por influências externas, como grupos políticos. Por essa razão, embora o exercício da profissão de jornalista esteja bem regulado tanto no Brasil quanto na Argentina, seu grau de profissionalização é baixo se medido pela "régua" do modelo "liberal".
} 
pese os dois países terem vivido um ciclo relativamente prolongado de regime democrático, o que teve algum reflexo sobre as políticas de comunicação, não se pode afirmar que tenha ocorrido uma alteração fundamental em um sistema de mídia consolidado nos períodos ditatoriais anteriores (SANTOS e PAULINO, 2015). Porém, as características específicas de Brasil e Argentina impossibilitam "encaixar" com precisão os dois países num dos modelos propostos por Hallin e Mancini, o que, de qualquer maneira, não é o objetivo deste trabalho. O relevante, aqui, é evidenciar que as semelhanças entre os sistemas mediáticos brasileiro e argentino são grandes o suficiente para autorizar a pretensão de um estudo comparado alicerçado na cobertura jornalística das respectivas campanhas presidenciais.

Feita essa categorização dos ambientes mediáticos brasileiro e argentino, procederemos no próximo capítulo ao detalhamento das escolhas metodológicas e de recorte da pesquisa, explicando nossa opção pelo colunismo político na análise dos analistas. Também faremos uma análise preliminar dos textos selecionados como forma de confirmar a relevância dessa opção no âmbito dos objetivos desta pesquisa. 


\section{Recorte da pesquisa}

\subsection{Definição da amostra}

Seria impraticável, nas condições de realização deste estudo, analisar todos os milhares de textos noticiosos, em jornais, revistas, sítios na internet, rádios e programas de TV, que fizeram referência às pesquisas eleitorais e as empregaram na análise das tendências do eleitorado nas eleições brasileira de 2014 e argentina em 2015. Por isso optamos por definir um corpus de pesquisa que fosse, ao mesmo tempo, quantitativamente viável e, por sua qualidade, representativo.

Essa busca nos levou a fechar nossa amostra em:

a) Textos de cunho analítico, por serem mais suscetíveis de utilizar os números das pesquisas, e que tratassem das respectivas campanhas presidenciais.

Podemos subdividir em categorias os textos que tratam das pesquisas. Há os essencialmente noticiosos, cuja função é descrever os resultados das pesquisas, em geral redigidos por jornalistas com alguma senioridade que os capacite a "mastigar" os números56, mas talvez ainda sem autoridade suficiente para uma análise subjetiva; e os textos analíticos, de caráter opinativo, assinados em geral por um destes três tipos de autor: jornalistas políticos de renome; diretores de empresas de pesquisa; ou cientistas políticos sem vínculo com essas empresas. Optamos pelos textos analíticos de jornalistas, por apresentarem, em nossa hipótese, maior probabilidade de conter o tipo de enquadramento realizado pelos veículos de comunicação.

b) Meios de comunicação "de prestígio" em seus respectivos países, ou seja: tradicionais, de grande circulação e reconhecida influência.

O conceito de prestígio é forçosamente subjetivo, mas a circulação paga de alcance nacional e o tempo de existência costumam ser bons indicadores da importância de um jornal no debate político de uma sociedade democrática. Assim, no Brasil, são três os jornais que indubitavelmente atendem esses critérios: a Folha de S. Paulo (fundada em 1921 como Folha da Manhã), O Globo (de 1925) e O Estado de S. Paulo

\footnotetext{
${ }^{56}$ Por exemplo, na Folha de S. Paulo, Ricardo Mendonça, editor de Política em 2014.
} 
(surgido como A Província de S. Paulo em 1875). Seria possível acrescer um jornal bem mais recente, o Valor Econômico (lançado no ano 2000), maior diário de informação financeira do país, mas sua ênfase nos aspectos econômicos (em que pese a reconhecida qualidade de sua análise política) nos levou a descartá-lo como opção de pesquisa. Na Argentina, destacam-se pela circulação, pela tradição e pelo prestígio o Clarín (de 1945) e o La Nación (de 1870). Ambos são de tendência conservadora, e de oposição ao governo de Cristina Fernández de Kirchner.

c) Colunistas fixos e regulares, de notório prestígio, com espaço cativo, de preferência ocupando há muitos anos o mesmo espaço, e em que a análise política fosse predominante.

Os jornais brasileiros têm uma longa tradição de colunistas políticos de prestígio, e nenhum representou mais essa tradição do que Carlos Castello Branco, colunista do Jornal do Brasil de 1963 até o ano de sua morte, 1993. Cogitou-se, para este projeto, analisar as colunas de Dora Kramer, do Estadão, uma das "herdeiras" de Castello Branco ${ }^{57}$; de Merval Pereira e Míriam Leitão, de $O$ Globo; ou de Eliane Cantanhêde e Fernando Rodrigues, da Folha, por serem estes os colunistas mais regulares de seus jornais à época da campanha eleitoral. ${ }^{58} \mathrm{Na}$ Argentina, Joaquín Morales Solá é o colunista de maior renome do La Nación; no Clarín, Eduardo van der Kooy assina desde 1990 uma coluna dominical de análise política; e Ricardo Kirschbaum, editor responsável do jornal, assina a coluna "Del editor al lector", de periodicidade irregular (três ou quatro vezes por semana).

Obedecidos esses critérios, convergimos para os nomes de Merval Pereira (1949-), de $O$ Globo, do Rio de Janeiro; Dora Kramer (1955-), de O Estado de S. Paulo; Joaquín Morales Solá (1950-), do La Nación; e Eduardo van der Kooy (1950), do Clarín, estes últimos, ambos, de Buenos Aires. No caso brasileiro, outros fatores além dos descritos acima influíram na escolha:

\footnotetext{
${ }^{57}$ Após a morte de seu titular, a Coluna do Castello foi assumida por Marcelo Pontes e, em 1995, por Dora Kramer, passando a chamar-se Coisas da Política. Em 2001, a coluna passou a ser publicada também pelo Estado de S. Paulo, batizada simplesmente com o nome da colunista. Em 2004 o Jornal do Brasil (cuja edição impressa deixaria de existir em 2010) cessou a publicação a coluna, o que na prática significa que o espaço de Dora Kramer no Estadão "descendia" da antiga Coluna do Castello do JB. Em dezembro de 2016 Kramer trocou o Estadão por uma coluna semanal na revista Veja.

${ }^{58}$ Após a eleição Cantanhêde migrou para o Estadão e Fernando Rodrigues deixou de publicar artigos na Folha, passando a escrever apenas para o portal UOL, pertencente ao mesmo grupo empresarial.
} 
- A Folha de S. Paulo pertence a um grupo proprietário de uma empresa de pesquisas, o que pode se refletir num maior uso destas em seus textos. Isto, em si, não impediria seu uso para os fins deste trabalho, mas poderia não ser representativo do tratamento dado às pesquisas eleitorais na imprensa como um todo;

- Dentre os dois colunistas de $O$ Globo citados, Pereira é eminentemente político, enquanto o viés de Míriam Leitão é econômico, o que tenderia a reduzir a relevância de sua análise num estudo sobre jornalismo político.

No caso argentino, mais especificamente do Clarín, foi preciso selecionar um entre vários colunistas de política. Optou-se por Van der Kooy por ser aquele que, além de possuir perfil profissional similar aos de Kramer, Pereira e Morales Solá (longa trajetória no jornalismo e no colunismo político, presença em outros meios além do impresso, prêmios jornalísticos), foi o que publicou maior número de colunas no jornal no período selecionado (26), além de ter sido aquele com mais "chamadas" de primeira página (17), indicativo da importância atribuída pelo próprio diário a seu analista. ${ }^{59}$

Além de os textos de Pereira, Kramer, Morales Solá e Van der Kooy atenderem os critérios acima, seus textos são mais extensos que os dos colunistas de outros jornais, e os quatro têm perfis profissionais bastante assemelhados, como atestam as biografias com que são apresentados na internet:

MERVAL PEREIRA é membro do Conselho Editorial do Grupo Globo. Faz parte do Board of Visitors da John S. Knight Fellowship, da Universidade Stanford. Recebeu os prêmios Esso de Jornalismo e Maria Moors Cabot. É da Academia Brasileira de Letras. ${ }^{60}$

DORA KRAMER é colunista de política do Estadão e comentarista da rádio Bandnews FM. Começou no jornalismo em 1973 e já passou por veículos como Agência Folha e Jornal do Brasil, onde ficou por 20 anos e inaugurou a coluna de política no espaço anteriormente ocupado por Carlos Castello Branco. $^{61}$

JOAQUÍN MORALES SOLÁ ejerce el periodismo desde los 16 años, cuando ingresó al diario La Gaceta de Tucumán. En 1975, Clarín lo convocó para ser prosecretario de la sección Política. Durante 12 años fue segundo jefe de

\footnotetext{
${ }^{59}$ Depois de Van der Kooy, os colunistas com maior número de menções na primeira página, no mesmo período, foram Alejandro Borensztein (15), Julio Blanck (15), Ricardo Roa (9), Alcadio Oña (8) e o diretor de redação do jornal, Ricardo Kirschbaum (seis menções).

${ }^{60}$ Disponível em http://blogs.oglobo.globo.com/merval-pereira/

${ }^{61}$ Disponível em http://politica.estadao.com.br/blogs/dora-kramer/
} 
Redacción y autor de la columna política dominical de ese diario. Fue columnista político del noticiero de Telefé y del programa "Tiempo Nuevo", de Bernardo Neustadt. Durante 1997, condujo "Dos en la noticia" junto con Magdalena Ruiz Guiñazú, por el ex Canal 9. Actualmente es columnista político del diario La Nación. En 1990, el gobierno de Italia lo condecoró con la Orden al Mérito de la República Italiana. Posteriormente, en 1992, España lo distinguió con la Orden de Isabel la Católica. En 1998, recibió la Orden Nacional al Mérito que entrega la república de Francia. En su último libro, "Sin excusas" (Sudamericana), Morales Solá revela diálogos con el ex vicepresidente Chacho Alvarez, sobre la trama secreta de los sobornos en el Senado, las causas de su renuncia y los errores que condujeron al fracaso de la Alianza. ${ }^{62}$

[EDUARDO VAN DER KOOY] Nació el 21/12/1950. Periodista. Ejerce el periodismo político en Clarín, diario donde además está a cargo de una columna dominical. Participó en 1998 en la confección de un libro sobre los 15 años de democracia, y de igual manera intervino con un trabajo sobre la crisis del año 2001, que editó también como libro el diario La Gaceta de Tucumán. Fue articulista del diario La Vanguardia de Barcelona sobre temas políticos del Cono Sur. Editó junto al ex canciller Rafael Bielsa dos versiones de un libro de cuentos y relatos de vida y fútbol. Desde 2008 co-conduce el programa "Código Político" en el canal TN. Recibió el premio Santa Clara de Asís a la trayectoria periodística. Con anterioridad había sido distinguido con el Premio Ortega y Gasset, del diario El País de Madrid, junto a Ricardo Kirschbaum y Oscar Cardoso, coautores de un libro sobre la guerra de las Malvinas. ${ }^{63}$

A notar, nas biografias acima, que enquanto as de Morales Solá e Van der Kooy relatam suas experiências desde o início da carreira, as de Kramer e Pereira são mais breves. Esta última faz referência apenas a fatos tardios, todos posteriores (à exceção do Prêmio Esso, outorgado em 1979) à assunção ao posto de colunista de O Globo. Para que esses breves retratos não fiquem desiguais neste trabalho, acrescentamos alguns dados biográficos do colunista brasileiro. Merval Pereira Filho começou no jornalismo em 1967, no Diário de Notícias, passando já no ano seguinte a $O$ Globo, onde trabalhou durante quase toda a carreira, com breves passagens pelo Jornal do Brasil e por Veja. Tornou-se diretor de redação de $O$ Globo em julho de 1995, substituindo Evandro Carlos de Andrade, que se transferira para a TV Globo. Em 3 de junho de 2003, estreou sua coluna, publicada de terça-feira a domingo, sucedendo Márcio Moreira Alves. ${ }^{64}$ Suas colunas foram parcialmente reunidas nas coletâneas $O$ Lulismo no Poder (2010) e Mensalão: o dia a dia do julgamento mais importante da história política do país

\footnotetext{
62 Disponível em http://www.lanacion.com.ar/autor/joaquin-morales-sola-51

${ }^{63} \mathrm{O}$ sítio do Clarín não publica biografia de Van der Kooy. A que apresentamos acima está disponível no sítio da Fundaciónn Konex, uma instituição filantrópica que lhe outorgou um prêmio em 2007, por suas análises políticas. Em http://www.fundacionkonex.org/b1510-eduardo-van-der-kooy.

${ }^{64}$ A maioria das informações sobre a trajetória de Pereira foi extraída de BLOCH (2003).
} 
(2013), ambos da editora Record. Além da coluna em $O$ Globo e de um blog no sítio do jornal na internet, faz comentários na rádio CBN e no canal GloboNews, todos do mesmo império de comunicação, o Grupo Globo. ${ }^{65}$ Cite-se ainda, por relevante, que Dora Kramer é comentarista da rádio BandNews FM; e Van der Kooy participa de um programa de rádio (“La Noche Arriba”, na FM Millenium).

Em comum, nas biografias de Kramer, Morales Solá, Pereira e Van der Kooy, encontram-se características que reforçam suas posições de prestígio dentro do campo jornalístico: a extensa trajetória, iniciada na função de repórter de rua, valorizada no ethos da profissão como estágio inicial da carreira; as posições de comando ocupadas em redações importantes; os livros publicados; a presença em diferentes meios (jornal, rádio, televisão, internet); os prêmios internacionais recebidos (mesmo que o leitor não saiba necessariamente o que representam essas comendas). As biografias publicadas nos sítios na internet informam ao leitor que aqueles jornalistas não estão ali por acaso: se ocupam aquele espaço é porque dispõem de credenciais que lhes conferem autoridade.

Cumpre ainda salientar o alinhamento das posições ideológicas dos quatro colunistas com a linha editorial de seus respectivos veículos. Como mencionado acima, Pereira é membro do Conselho Editorial do Grupo Globo - ou seja, participa ativamente das discussões e decisões relativas às tomadas de posição políticas dos veículos da corporação. Morales Solá e Van der Kooy estão entre os principais editorialistas de seus jornais, representando-os em diversos eventos corporativos. Por fim, Dora Kramer, embora não tivesse vínculo com a direção de $O$ Estado de S. Paulo, afirmou ao despedir-se do jornal:

\footnotetext{
[N]os demos muito bem. A insegurança inicial foi sendo substituída pela identificação. Com a linha de pensamento do jornal e com o abrigo carinhoso dos leitores (...). A liberdade de expressão, constantemente pregada nos editoriais, é exercida na prática. Nesses 15 anos, nem uma vez fui advertida ou pautada. Nunca a direção de $O$ Estado interferiu. Seja pedindo a abordagem de um assunto ou impondo restrições a outro. A liberdade de expressão aqui é um exercício de fato (KRAMER, $12 \mathrm{dez} .2016$ ).
}

\footnotetext{
${ }^{65} \mathrm{Em}$ agosto de 2014, as antigas Organizações Globo passaram a se chamar Grupo Globo, reunindo Infoglobo (jornais O Globo, Extra e Expresso e participação no Valor Econômico), TV Globo, Globosat (canais de televisão por assinatura, entre eles a GloboNews), Globo.com (internet), Globo Filmes (cinema), Sistema Globo de Rádio (emissoras CBN e Globo), Editora Globo (revistas e livros), Som Livre (área musical), Globo Internacional (distribuidora de programação de TV fora do Brasil) e Zap (portal de classificados online).
} 
A "liberdade de expressão" irrestrita a que Kramer se refere, porém, pode ser interpretada de outra maneira: se sua "linha de pensamento" se identifica com a do jornal, é possível que a direção nunca tenha "interferido" em suas colunas por nunca a colunista ter escrito algo que pudesse ser incômodo a essa mesma direção.

\subsection{Corpus de pesquisa}

Nosso corpus de pesquisa consistiu, portanto, para a eleição presidencial brasileira, em 63 artigos publicados por Merval Pereira no jornal $O$ Globo e 52 artigos publicados Dora Kramer em O Estado de S. Paulo entre 14 de agosto de 2014, dia seguinte à morte do candidato Eduardo Campos, e 26 de outubro do mesmo ano, data do segundo turno da eleição presidencial. Nossa opção por esse período (83 dias) se deve, antes de tudo, à reviravolta na campanha provocada pelo desastre aéreo que vitimou o candidato do PSB e seu entourage; e por constituir, em nosso entender, uma amostra suficiente para detectar os enquadramentos efetuados pelos autores (aproximadamente 90 páginas de formatação semelhante a estas).

Quanto à eleição presidencial argentina, definimos como amostra 29 artigos publicados por Joaquín Morales Solá no La Nación e 26 artigos publicados por Eduardo van der Kooy no Clarín entre 19 de agosto de 2015, primeira coluna após as eleições primárias abertas, e 22 de novembro do mesmo ano. O período foi escolhido pelo paralelismo temporal com a eleição brasileira do ano anterior, pela ocorrência das primárias ("PASO"), que podem ser consideradas o ponto de partida da "verdadeira" campanha eleitoral, e por entendermos tratar-se de uma amostra suficientemente representativa e passível de comparação. Embora representem menos da metade do número de artigos assinados por Pereira e Kramer no período análogo, os textos dos colunistas do La Nación e do Clarín são mais extensos e ocupariam, somados, aproximadamente cem páginas no formato desta dissertação.

Resumimos da seguinte forma o conteúdo dos artigos selecionados para a pesquisa $^{66}$ :

\footnotetext{
${ }^{66} \mathrm{~A}$ lista completa dos artigos, com título, data de publicação e página, se encontra nas Referências deste trabalho.
} 
Dora Kramer - 52 textos, publicados às terças, quartas, quintas, sextas-feiras e domingos (à exceção de um texto publicado na segunda-feira subsequente ao primeiro turno da eleição presidencial de 2014), em geral no terço superior da pág. A6 de $O$ Estado de S. Paulo (jornal em formato standard), tendo em média 600 palavras $^{67}$ ou 3.600 caracteres; ao todo, 32 mil palavras ou 189 mil caracteres.

Merval Pereira - 63 textos, publicados de terça-feira a domingo no terço esquerdo da página 4 de $O$ Globo (jornal em formato standard), tendo em média 700 palavras ou 4.200 caracteres; ao todo, 45 mil palavras ou 265 mil caracteres.

Eduardo van der Kooy - 26 textos, publicados às quartas-feiras e domingos (e eventualmente às segundas e terças-feiras) em página inteira do Clarín (jornal em formato tabloide), geralmente a página 45 aos domingos e uma página variável (entre 6 e 13) nos demais dias da semana. Seus artigos tinham em média 1.300 palavras ou 8.100 caracteres; ao todo, 34 mil palavras ou 212 mil caracteres.

Joaquín Morales Solá - 29 textos, publicados às quartas-feiras e domingos (e eventualmente em outros dias da semana, exceto o sábado) em espaço variável no $L a$ Nación (jornal em formato standard), geralmente a página 31 ou 33 aos domingos e uma página variável (entre 5 e 13) nos demais dias da semana. Seus artigos tinham em média 1.300 palavras ou 7.600 caracteres; ao todo, 33 mil palavras ou 199 mil caracteres.

Virtualmente todos os 170 textos (144 mil palavras, ou 865 mil caracteres) fazem referência às respectivas campanhas eleitorais. Apenas numa ocasião, por exemplo, Pereira não faz referência nominal a nenhum dos três principais candidatos; mas é para, a pretexto de traçar um histórico das "campanhas de descontrução", fazer uma crítica a João Santana, o "marqueteiro" de Dilma Rousseff. Da mesma forma, num único artigo Morales Solá não menciona Scioli, nem Macri, nem Massa; mas é para, ao apresentar um histórico de denúncias de fraude eleitoral contra o governo, insinuar que o resultado das eleições poderia ser manipulado em favor de Scioli. Portanto, a íntegra dos textos diz respeito às eleições, o que reforça sua validade como objeto de estudo do uso das pesquisas eleitorais no enquadramento da cobertura.

Procedemos à leitura preliminar de cada um desses textos anotando as referências a pesquisas de intenção de voto e outros levantamentos de opinião,

\footnotetext{
${ }^{67}$ Todos os valores aqui apresentados foram arredondados em nome da simplificação.
} 
qualitativos ou quantitativos, que porventura fossem mencionados e nos parecessem relevantes para os fins da pesquisa. Buscamos detectar neles os temas de agendamento; padrões de enquadramento e similaridades estruturais que validassem a ideia do estudo comparativo, para a elaboração de uma ficha de análise. Também compilamos o número de referências a cada candidato e a outros políticos importantes do presente ou do passado. No próximo capítulo começaremos a proceder à análise das colunas. 


\section{Influências das pesquisas sobre o conteúdo das colunas}

\subsection{Critérios de relevância}

Já está demonstrada, quantitativamente, a preponderância das pesquisas eleitorais na cobertura das campanhas eleitorais, tanto no Brasil quanto em outros países (BIROLI, MIGUEL e MOTA, 2011). Como mostrado nos Apêndices II e III deste trabalho, em diversos momentos, durante os meses finais de campanha, as primeiras páginas dos diários brasileiros e argentinos foram dominadas por manchetes relacionadas aos números das pesquisas de intenção de voto. No caso brasileiro, foram 16 manchetes de primeira página do Estado de S. Paulo e 15 de $O$ Globo nos 73 dias de cobertura analisados; no caso argentino, tanto Clarín quanto La Nación publicaram títulos de primeira página relativos às pesquisas sete vezes no período de campanha analisado, de 96 dias.

A presença menor desse tipo de manchete nos jornais argentinos pode ser atribuída à maior dispersão, mencionada acima, do mercado de empresas de pesquisa de opinião pública; note-se que tanto o Clarín quanto La Nación privilegiaram as empresas por eles próprios contratadas (respectivamente, Management \& Fit e Poliarquía). No período analisado, cada um dos diários encomendou apenas duas pesquisas, uma no primeiro turno e outra no segundo. Note-se ainda que os jornais burlaram a veda que impedia a divulgação de pesquisas nos oito dias anteriores a cada turno eleitoral, fazendo referência às sondagens - em alguns casos publicando até números -, sem, porém, mencionar diretamente as empresas responsáveis pelos levantamentos. Isso explica por que mesmo durante o período de proibição houve manchetes relativas às pesquisas nos dois principais jornais argentinos, como mostra o Apêndice III.

No Brasil, o maior contratante de pesquisas na campanha de 2014, nos meios de comunicação de massa, foi a TV Globo; foram nada menos que 25 pesquisas em 102 dias de campanha - 19 no primeiro turno (oito encomendadas ao Ibope, em parceria com O Estado de S. Paulo; e oito encomendadas ao Datafolha, em parceria com o jornal Folha de S. Paulo), a partir do dia 17 de julho; e nove pesquisas no segundo turno (quatro encomendadas ao Ibope, em parceria com O Estado de S. Paulo; e cinco 
encomendadas ao Datafolha, em parceria com o jornal Folha de S. Paulo), a partir de 10 de outubro.

A elaboração das categorias de análise dos textos que compõem o corpus deste estudo foi feita a partir de uma leitura que procurou detectar paralelos entre os respectivos conteúdos. A leitura inicial identificou a necessidade de levantar, como ponto de partida, aspectos como: menções aos candidatos da campanha presidencial em curso; menções a outros políticos e personalidades (por exemplo, assessores) envolvidos com a campanha; menções a outras campanhas simultâneas à presidencial (por exemplo, as legislativas); menções a governos e eleições anteriores; menções a pesquisas eleitorais divulgadas pela imprensa, a pesquisas não divulgadas ou ainda por divulgar, ou a subgrupos do eleitorado com base em números das pesquisas; e menções a empresas de pesquisa.

Embora o objetivo deste trabalho não seja realizar uma análise quantitativa de conteúdo, em razão do número de textos analisados, julgamos relevante fazer um levantamento do número de menções para cada uma das categorias citadas acima, como forma de determinar a pertinência das categorias de análise. Para facilitar a comparação, os números apresentados são os percentuais em relação ao total de textos de cada autor (63 de Pereira, 52 de Kramer, 29 de Morales Solá e 26 de Van der Kooy). Não foi feita diferenciação entre textos publicados antes e depois do primeiro turno de cada eleição presidencial, pois não foram constatadas grandes diferenças de conteúdo além daquelas esperadas - naturalmente, após o primeiro turno diminuem as menções aos candidatos eliminados, assim como tendem a se reduzirem as referências a questões como o voto útil, típicas de uma campanha de primeiro turno. Estas, porém, serão abordadas mais adiante, na análise dos enquadramentos da cobertura.

\section{a) Menções aos candidatos da campanha em curso}

Como seria de esperar, na esmagadora maioria dos textos analisados pelo menos um dos candidatos é mencionado, salvo exceções em que o tema da coluna, ainda que fosse a campanha, não exigia menção nominal. É o caso, por exemplo, da coluna de Merval Pereira de 19 de outubro, dedicada a traçar um histórico das campanhas 
eleitorais de "propaganda negativa" nos Estados Unidos, em referência indireta àquela desfechada por Dilma Rousseff contra Aécio Neves.

Note-se, na Tabela 12, abaixo, a omissão quase total dos candidatos que não figuraram entre os três principais nas pesquisas. No caso brasileiro, foram incluídas as menções a Eduardo Campos. Embora o candidato original do PSB tenha morrido antes do período pesquisado, sua influência se estendeu por todo o curso da campanha.

Nesta tabela e nas subsequentes, a soma das menções pode superar os $100 \%$ pelo fato de referências a diferentes pessoas ou questões ligadas a campanha poderem ocorrer no mesmo texto.

Tabela 12 - Menções aos candidatos da campanha presidencial em curso nas colunas de Pereira, Kramer, Morales Solá e Van der Kooy

\begin{tabular}{|c|c|c|}
\hline \multirow{2}{*}{ Candidato } & \multicolumn{2}{|c|}{ Colunas com menções } \\
\cline { 2 - 3 } & Pereira & Kramer \\
\hline Dilma Rousseff & $86 \%$ & $90 \%$ \\
\hline Marina Silva & $86 \%$ & $73 \%$ \\
\hline Aécio Neves & $83 \%$ & $65 \%$ \\
\hline Eduardo Campos & $44 \%$ & $35 \%$ \\
\hline Luciana Genro & $3 \%$ & $2 \%$ \\
\hline Pastor Everaldo & $2 \%$ & $2 \%$ \\
\hline Outros & - & - \\
\hline
\end{tabular}

\begin{tabular}{|c|c|c|}
\hline \multirow{2}{*}{ Candidato } & \multicolumn{2}{|c|}{ Colunas com menções } \\
\cline { 2 - 3 } & Morales Solá & Van der Kooy \\
\hline Daniel Scioli & $93 \%$ & $100 \%$ \\
\hline Mauricio Macri & $93 \%$ & $100 \%$ \\
\hline Sergio Massa & $55 \%$ & $92 \%$ \\
\hline Margarita Stolbizer & $14 \%$ & $19 \%$ \\
\hline Adolfo Rodríguez Saá & $7 \%$ & $12 \%$ \\
\hline Nicolás del Caño & - & $8 \%$ \\
\hline
\end{tabular}

Fonte: Elaboração própria. 
b) Menções a outros políticos e personalidades (por exemplo, assessores) envolvidos com a campanha

Tanto nos textos de Kramer e Pereira quanto nos de Morales Solá e Van der Kooy o "mentor" do candidato do governo é a figura mais mencionada: o ex-presidente Lula (antecessor de Dilma na presidência), no caso brasileiro, e a presidente Cristina Fernández de Kirchner, no caso argentino (Cristina Fernández, inclusive, é citada por Morales Solá em mais textos que qualquer dos candidatos). Na campanha argentina se nota a citação frequente dos políticos mais influentes ligados ao kirchnerismo, como Aníbal Fernández (chefe de gabinete de Cristina Fernández de Kirchner, com quem não tem parentesco). Os companheiros de chapa dos candidatos quase não merecem menção. Note-se que as menções a Lula são menos frequentes, nas colunas brasileiras, que as menções a Cristina nas colunas argentinas; se em parte isto pode ser atribuído ao maior afastamento temporal em relação ao período de Lula na Presidência (2003-11) Cristina Fernández ainda estava no poder no momento da campanha argentina -, podese conjecturar sobre outras motivações por trás da omissão parcial do papel desempenhado por Lula como "puxador de votos" para a candidata à reeleição. Chama a atenção, por fim, a referência mais constante, nos textos dos colunistas argentinos, aos personagens em torno dos candidatos.

Tabela 13 - Menções a outros políticos e personalidades (por exemplo, assessores) envolvidos com a campanha nas colunas de Pereira, Kramer, Morales Solá e Van der Kooy

\begin{tabular}{|c|c|c|}
\hline \multirow{2}{*}{ Políticos } & \multicolumn{2}{|c|}{ Colunas com menções } \\
\cline { 2 - 3 } & Pereira & Kramer \\
\hline Lula & $48 \%$ & $52 \%$ \\
\hline Ligados aos candidatos & $10 \%$ & $23 \%$ \\
\hline Companheiro de chapa & $10 \%$ & $4 \%$ \\
\hline
\end{tabular}

\begin{tabular}{|c|c|c|}
\hline \multirow{2}{*}{ Políticos } & \multicolumn{2}{|c|}{ Colunas com menções } \\
\cline { 2 - 3 } & Morales Solá & Van der Kooy \\
\hline Cristina F. Kirchner & $93 \%$ & $100 \%$ \\
\hline Ligados aos candidatos & $62 \%$ & $100 \%$ \\
\hline Companheiro de chapa & $14 \%$ & $31 \%$ \\
\hline \multicolumn{2}{|r}{ Fonte: Elaboração própria. }
\end{tabular}


c) Menções a outras campanhas simultâneas à presidencial (por exemplo, as

\section{legislativas)}

Tanto no Brasil quanto na Argentina, foram realizadas eleições para os cargos de governador, senador e deputado ao mesmo tempo em que as presidenciais, com algumas variações já relacionadas no final do primeiro capítulo. Seria de esperar que esses outros pleitos figurassem em algum momento nos textos dos colunistas. As campanhas para os governos estaduais/provinciais são mencionadas com alguma frequência. Mas a referência quase sempre é relativa ao impacto da campanha regional sobre o pleito nacional - por exemplo, a importância, para o mineiro Aécio Neves, de um triunfo de Pimenta da Veiga, candidato de seu partido ao governo de Minas Gerais, na medida em que isso aumentaria as chances do próprio Aécio de obter boa votação em seu estado natal. Na campanha argentina, o tema regional mais citado por Joaquín Morales Solá foi a eleição provincial em Tucumán. Ocorrida, por idiossincrasias do calendário eleitoral argentino, em 23 de agosto de 2015 - ou seja, dois meses antes da eleição nacional -, a votação foi marcada por denúncias de irregularidades. Morales Solá discutiu, em diversas colunas, o risco de extensão da fraude eleitoral ao pleito presidencial. Morales Solá é originário de Tucumán, o que pode ter influenciado seu interesse pela questão, mas independentemente desse vínculo pessoal o caso da eleição provincial ocupou o noticiário de todos os principais veículos de comunicação argentinos até meados de setembro. As eleições legislativas, por sua vez, são pouco citadas por Pereira (e sempre dentro da perspectiva da eleição para o Executivo) e ignoradas por Morales Solá.

Tabela 14 - Menções a outras campanhas (estaduais/provinciais ou legislativas) nas colunas de Pereira, Kramer, Morales Solá e Van der Kooy

\begin{tabular}{|c|c|c|}
\hline \multirow{2}{*}{ Tipo de eleição } & \multicolumn{2}{|c|}{ Colunas com menções } \\
\cline { 2 - 3 } & Pereira & Kramer \\
\hline Estaduais & $44 \%$ & $21 \%$ \\
\hline Legislativas & $13 \%$ & $23 \%$ \\
\hline
\end{tabular}

\begin{tabular}{|c|c|c|}
\hline \multirow{2}{*}{ Tipo de eleição } & \multicolumn{2}{|c|}{ Colunas com menções } \\
\cline { 2 - 3 } & Morales Solá & Van der Kooy \\
\hline Estaduais & $48 \%$ & $92 \%$ \\
\hline Legislativas & $3 \%$ & $38 \%$ \\
\hline
\end{tabular}

Fonte: Elaboração própria. 


\section{d) Menções a governos anteriores}

Referências ao passado ajudam a contextualizar a análise do presente. Portanto, é de esperar que os articulistas recorram a essas referências. Aqui recolhemos as menções a ex-presidentes que tivessem relação com a campanha em curso. Observou-se que tanto no caso brasileiro quanto no argentino não houve referência ao período ditatorial mais recente (1964-85 no Brasil; 1976-83 na Argentina). Morales Solá e Van der Kooy, seguindo um costume argentino, fazem amplo uso do nome de políticos sob a forma das correntes que lideram (peronismo, menemismo, duhaldismo, kirchnerismo, cristinismo etc., e, no caso da eleição atual, macrismo, massismo, sciolismo). Optou-se, aqui, por listar apenas as menções nominais. Curiosamente, apesar da enorme influência que teve - a ponto de seu nome ainda batizar a corrente política mais tradicional do país -, Juan Domingo Perón (1895-1974) é citado em apenas uma das 55 colunas argentinas. Pode-se atribuir esse fato à gradual transformação do sentido do termo "peronismo" com o passar dos anos, diluído em numerosas correntes bastante distintas umas das outras.

Tabela 15 - Menções a governos anteriores nas colunas de Pereira, Kramer, Morales Solá e Van der Kooy

\begin{tabular}{|c|c|c|}
\hline \multirow{2}{*}{ Governo anterior } & \multicolumn{2}{|c|}{ Colunas com menções } \\
\cline { 2 - 3 } & Pereira & Kramer \\
\hline Lula & $48 \%$ & $52 \%$ \\
\hline Fernando H. Cardoso & $21 \%$ & $21 \%$ \\
\hline Fernando Collor & $13 \%$ & $13 \%$ \\
\hline José Sarney & $3 \%$ & $2 \%$ \\
\hline Itamar Franco & $2 \%$ & $2 \%$ \\
\hline Jânio Quadros & $2 \%$ & $4 \%$ \\
\hline Getúlio Vargas & - & $2 \%$ \\
\hline
\end{tabular}

\begin{tabular}{|c|c|c|}
\hline \multirow{2}{*}{ Governo anterior } & \multicolumn{2}{|c|}{ Colunas com menções } \\
\cline { 2 - 3 } & Morales Solá & Van der Kooy \\
\hline Néstor Kirchner & $24 \%$ & $12 \%$ \\
\hline Carlos Menem & $10 \%$ & $4 \%$ \\
\hline Eduardo Duhalde & $7 \%$ & $4 \%$ \\
\hline Fernando de la Rúa & - & $4 \%$ \\
\hline Raúl Alfonsín & - & $4 \%$ \\
\hline Arturo Illía & $3 \%$ & - \\
\hline Isabel Perón & $3 \%$ & - \\
\hline Juan Domingo Perón & - & $3 \%$ \\
\hline \multicolumn{2}{|c|}{ Fonte: Elaboração própria. } \\
\hline
\end{tabular}

Fonte: Elaboração própria. 
e) Menções a pesquisas divulgadas pela imprensa, a pesquisas não divulgadas ou por divulgar, ou a subgrupos do eleitorado com base em pesquisas

Os números das pesquisas eleitorais influenciam o comentário dos analistas mesmo quando não são diretamente mencionados - por exemplo, na decisão de comentar apenas as campanhas dos candidatos mais bem situados nas sondagens. Mas é importante quantificar as menções diretas às pesquisas, sejam elas de conhecimento público ou não. Também nos interessamos por quantificar as menções, dentro da análise das pesquisas, a subgrupos do eleitorado - por exemplo, em que regiões do país, em que faixa etária ou de renda familiar as pesquisas apontam vantagem deste ou daquele candidato. Esse tipo de referência traduz uma intenção de aprofundar a análise a partir dos números, numa tentativa de detectar tendências mais específicas, que o número geral extraído do universo dos pesquisados não permitiria entrever. Dos quatro colunistas, Van der Kooy, do Clarín, é o que menos faz uso das pesquisas, que mesmo assim são mencionadas em cerca de um terço de suas colunas. Pereira, de $O$ Globo, é o que mais recorre a elas. Não apenas os números dos levantamentos figuram em dois terços de suas colunas, mas em várias delas ele se dedica a esmiuçar os números por região, sem levar em conta o aumento da "margem de erro" devido ao fato de estar analisando um subgrupo do universo de entrevistados. Dora Kramer, no Estado de S. Paulo, é mais genérica em sua utilização das pesquisas, valendo-se em geral apenas dos totais nacionais. Tanto Pereira quanto Morales Solá, do La Nación, recorrem esporadicamente a informações de bastidores - pesquisas feitas pelas campanhas e cuja divulgação detalhada não estava autorizada pela lei.

Tabela 16 - Menções a pesquisas eleitorais ou a subgrupos do eleitorado nas colunas de Pereira, Kramer, Morales Solá e Van der Kooy

\begin{tabular}{|c|c|c|}
\hline \multirow{2}{*}{ Tipo de menção } & \multicolumn{2}{|c|}{ Colunas com menções } \\
\cline { 2 - 3 } & Pereira & Kramer \\
\hline Pesquisas divulgadas & $66 \%$ & $52 \%$ \\
\hline Subgrupos do eleitorado & $27 \%$ & $10 \%$ \\
\hline Pesquisas não divulgadas & $15 \%$ & $4 \%$ \\
\hline
\end{tabular}

\begin{tabular}{|c|c|c|}
\hline \multirow{2}{*}{ Tipo de menção } & \multicolumn{2}{|c|}{ Colunas com menções } \\
\hline & Morales Solá & Van der Kooy \\
\hline Pesquisas divulgadas & $54 \%$ & $31 \%$ \\
\hline Pesquisas não divulgadas & $25 \%$ & $8 \%$ \\
\hline Subgrupos do eleitorado & $11 \%$ & $8 \%$ \\
\hline
\end{tabular}

Fonte: Elaboração própria. 


\section{f) Menções a empresas de pesquisas}

Outro indicador da influência das pesquisas eleitorais sobre a análise da campanha são as citações às empresas de pesquisas eleitorais. Aqui se verificou uma diferença significativa entre os colunistas estudados: enquanto nos textos de Pereira e Kramer são frequentes as menções às duas empresas mais reconhecidas, Datafolha e Ibope, nos de Morales Solá e Van der Kooy se encontram muito menos referências; Morales Solá menciona uma única encuestadora, a Poliarquía, que realiza os levantamentos publicados pelo La Nación. Uma hipótese para explicar essa discrepância é o maior prestígio de que gozam as empresas de pesquisa no Brasil, pelo tempo de existência e pela imagem de relativa independência em relação aos partidos, ao passo que as empresas desse tipo na Argentina são relativamente mais recentes, assim como são notórios seus vínculos com esta ou aquela corrente política. Morales Solá não cita nominalmente nenhum diretor de empresa de pesquisa, analista ou cientista social. Faz, porém, várias referências a "analistas", "analistas políticos", “analistas de opinião pública" e "pesquisadores”, sempre como fontes anônimas. Como no caso anterior, acreditamos que as dúvidas em relação à credibilidade das agencias de encuestas argentinas tenham a ver com a opção pelo anonimato ao usar seus diretores como fonte. Pereira recorre, ainda que com pouca frequência, a declarações de Mauro Paulino, diretor do Datafolha, e de cientistas sociais.

Tabela 17 - Menções a empresas de pesquisas nas colunas de Pereira, Kramer, Morales Solá e Van der Kooy

\begin{tabular}{|c|c|c|}
\hline \multirow{2}{*}{ Empresa } & \multicolumn{2}{|c|}{ Menções } \\
\cline { 2 - 3 } & Pereira & Kramer \\
\hline Datafolha & $47 \%$ & $12 \%$ \\
\hline Ibope & $31 \%$ & $10 \%$ \\
\hline Vox Populi & $5 \%$ & - \\
\hline MDA & $3 \%$ & $2 \%$ \\
\hline Sensus & $2 \%$ & - \\
\hline
\end{tabular}

\begin{tabular}{|c|c|c|}
\hline \multirow{2}{*}{ Empresa } & \multicolumn{2}{|c|}{ Menções } \\
\cline { 2 - 3 } & Morales Solá & Van der Kooy \\
\hline González y Valladares & - & $8 \%$ \\
\hline Poliarquía & $8 \%$ & - \\
\hline Ibarómetro & - & $4 \%$ \\
\hline Areco & - & $4 \%$ \\
\hline CEOP & - & $4 \%$ \\
\hline Polldata & - & $4 \%$ \\
\hline Management \& Fit & - & $4 \%$ \\
\hline
\end{tabular}

Fonte: Elaboração própria. 


\subsection{A agenda da mídia e dos colunistas}

Identificamos, na análise dos textos dos comentaristas de $O$ Globo, $O$ Estado de S. Paulo, La Nación e Clarín, diversas instâncias de agendamento do debate político, caracterizadas, dentro da definição de McCombs e Shaw (1972), como temas selecionados dentre os diversos presentes no debate político. Embora esses temas sejam específicos de cada país, é possível estabelecer conexões entre eles.

Os temas que servem ao agendamento se originam de diferentes fontes. Podem ser lançados à arena pública pelo governo, pela oposição, pelos partidos em suas campanhas eleitorais ou pela imprensa. Em geral se prestam a enquadramentos favoráveis ou desfavoráveis a um candidato, podendo eventualmente envolver mais de um candidato ao mesmo tempo. Podemos citar como exemplos os seguintes episódios extraídos da eleição brasileira:

- A acusação, feita por Aécio Neves, de que Igor Rousseff, irmão da presidente da República, fora funcionário-fantasma da prefeitura de Belo Horizonte. Aécio lançou mão dessa cartada no debate televisivo de 16 de outubro, realizado no canal aberto SBT, depois que Dilma o acusou de empregar a irmã Andrea no governo de Minas Gerais. O tema seria explorado pela imprensa nos dias subsequentes.

- A denúncia de que, quando governador de Minas Gerais, Aécio Neves fez construir um aeroporto nas terras de sua família, no município de Cláudio, para proveito pessoal. Essa informação, que já era de conhecimento das redações mineiras, mas fora abafada pela pressão política sobre a mídia local ${ }^{68}$, acabaria lançada na campanha nacional pela manchete da Folha de S. Paulo de 20 de julho. No final de 2015, a investigação sobre a construção do aeroporto foi arquivada.

- A peça de propaganda, veiculada pela campanha de Dilma Rousseff a partir da segunda semana de setembro, insinuando que Marina Silva "tiraria a comida do prato" dos brasileiros mais pobres caso concedesse, como constava do programa de governo do PSB, autonomia ao Banco Central.

Governo e oposição, o mais das vezes, lançam suas pautas à agenda pública por intermédio dos meios de comunicação, seja no noticiário, seja no horário eleitoral

\footnotetext{
${ }^{68}$ Sobre a relação peculiar do poder com a imprensa em Minas Gerais, ver CARRATO (2002).
} 
gratuito de rádio e televisão. A imprensa, por sua vez, também lança temas para a agenda, sejam estes levantados pelos jornalistas, pautados por fontes com interesse direto ou impostos pelos acontecimentos, independente do desejo das fontes de vê-lo destacado ou ignorado. O desastre aéreo que matou Eduardo Campos e sua comitiva, por exemplo, foi um acontecimento inescapável na campanha brasileira de 2014, alheio à vontade das campanhas ${ }^{69}$ e de grande influência na pauta do noticiário até, pelo menos, a realização do primeiro turno. Outro exemplo são as manifestações que tomaram conta do país em junho de 2013, que não estavam nos cálculos de campanha do governo nem da oposição, e cujos reflexos pairaram sobre o debate eleitoral.

Essas categorias não são estanques, podendo ter pontos em comum. A Operação Lava-Jato, em que Ministério Público e Polícia Federal investigaram a corrupção na Petrobras, pode ter nascido independente de objetivos eleitorais, mas não se pode descartar, haja vista os chamados "vazamentos seletivos" de depoimentos e detalhes da investigação para a imprensa ao longo da campanha, um elemento intencional na forma como foi conduzida.

O destaque desses temas na agenda pública, tanto no tempo quanto no espaço, é determinado - aqui aludimos a Bourdieu (1995) - pelas lutas, dentro dos campos político, jornalístico e das ciências sociais, para impor uma determinada construção da realidade. Nos textos dos quatro colunistas analisados, pode-se identificar uma tendência a explorar mais extensamente os temas desfavoráveis ao governo, enquanto aqueles desagradáveis à oposição (e mais especificamente a Aécio Neves e Mauricio Macri) eram tratados mais ligeiramente ou ignorados.

- Nos textos de Dora Kramer e Merval Pereira, diversas pautas inconvenientes para a campanha de Aécio pouco ou nunca figuraram. O caso do aeroporto de Cláudio é mencionado por Pereira uma única vez no período estudado, em 26 de agosto (e nenhuma vez por Kramer), e o local é chamado de "aeródromo", termo que diminui a importância da obra e o mesmo empregado pela assessoria de Aécio em sua defesa ${ }^{70}$.

\footnotetext{
69 Teorias conspiratórias a respeito do acidente, que tiveram amplo curso nas redes sociais nos dias seguintes ao acidente, não prosperaram, confrontadas à falta de evidências que pudessem pôr em dúvida a hipótese de falha do piloto como causa da queda do avião.

70 Tecnicamente, na definição da Agência Nacional de Aviação Civil (Anac), "Aeroportos são os aeródromos públicos dotados de instalações e facilidades para apoio de operações de aeronaves e de embarque e desembarque de pessoas e cargas", definição que se aplica às instalações de Cláudio.
} 
Outra acusação contra Aécio, a de que teria se recusado a se submeter ao teste do bafômetro, em uma blitz policial no Rio de Janeiro ocorrida em 17 de abril de $2011^{71}$, é mencionada por Pereira apenas duas vezes (e nenhuma por Kramer), e numa delas sob enquadramento positivo para Aécio e negativo para Dilma (“O candidato Aécio Neves aparentemente reagiu ao ataque baixo com tranquilidade"). Outra acusação de ordem pessoal contra Aécio, a de ter agredido a namorada (e posteriormente esposa, Letícia Weber) numa festa no Rio de Janeiro em $2009^{72}$, merece apenas uma menção indireta de Pereira, favorável ao candidato do PSDB, discutindo não a veracidade da informação, mas o caráter de quem a disseminava ("[Lula] ajuda a disseminar a ideia de que o adversário agride mulheres, inclusive fisicamente, como a rede suja da internet espalha incessante e anonimamente"). O chamado "Mensalão do PSDB", em que a cúpula do partido em Minas Gerais era acusada de se beneficiar de esquema de corrupção semelhante ao do PT, não foi mencionado pelos colunistas brasileiros.

- Nos artigos de Eduardo Van der Kooy e Joaquín Morales Solá, são raras as menções a temas da pauta considerados incômodos à campanha de Mauricio Macri. $\mathrm{O}$ mais proeminente foi o caso de Fernando Niembro. Em setembro de 2015, Niembro, um dos aliados mais próximos de Macri, foi acusado de ser beneficiário de contratos de publicidade milionários, atribuídos a ele diretamente por Macri, quando governador da Cidade Autônoma de Buenos Aires. Em 15 de setembro, Niembro renunciou a sua candidatura a deputado. Van der Kooy cita o caso duas vezes, de passagem (numa delas para dizer que o escândalo foi “manipulado pelo kirchnerismo"), e Morales Solá uma única vez, em 13 de setembro, num enquadramento que, embora reconhecendo que o episódio era embaraçoso, insinua que o kirchnerismo estaria por trás da denúncia e que adotaria as mesmas práticas que denunciava:

Es cierto, igualmente, que los denunciantes son medios kirchneristas que se hicieron millonarios con un modo generoso y arbitrario de dar publicidad oficial por parte de Cristina Kirchner. (...) Ahora bien, ¿eso significa que lo que sucedió con Niembro está bien? (...) El problema es que no se trata sólo de

\footnotetext{
${ }^{71}$ Extra, 19 abr. 2011, p. 1. A chamada de primeira página é uma brincadeira com a sigla do partido de Aécio: "Porre é Soprar o Danado do Bafômetro".

72 O episódio foi relatado pela primeira vez em 26 out. 2009 pelo site Glamurama, da jornalista Joice Pascowitch, identificando o agressor apenas como "um os convidados mais importantes e famosos da festa". O nome de Aécio foi divulgado seis dias depois por outro jornalista, Juca Kfouri, em seu blog. A assessoria de Aécio Neves negou os fatos.
} 
la legalidad, sino también de la ética y la estética que requiere la política. Y ambas cosas faltaron en este caso. Un candidato beneficiado en su actividad privada con contratos que le suministró el propio partido del que es candidato no es un buen mensaje de cambio hacia la sociedad. (MORALES SOLÁ, 13 set. 2015)

As tabelas a seguir apresentam listas de temas de agenda identificados nos textos dos quatro colunistas. Note-se a preponderância de temas relacionados ao governo - o que não surpreende, considerando que num regime presidencialista é comum que as eleições se convertam numa espécie de "plebiscito" pela continuidade ou mudança. Chama a atenção, porém, a escassez de discussão de propostas programáticas da oposição, tanto no caso brasileiro quanto no argentino. No Apêndice I deste estudo cada um dos temas citados nas tabelas abaixo é contextualizado.

Tabela 18 - Temas relativos à campanha de Dilma Rousseff nas colunas de Pereira e Kramer

\begin{tabular}{|c|c|c|}
\hline Tema & Pereira & Kramer \\
\hline Petrobrás/Operação Lava-Jato & $\sqrt{ }$ & $\sqrt{ }$ \\
\hline Baixaria na campanha & $\sqrt{ }$ & $\sqrt{ }$ \\
\hline Desconstrução de Marina/Aécio & $\sqrt{ }$ & $\sqrt{ }$ \\
\hline Perspectiva ruim da economia & $\sqrt{ }$ & $\sqrt{ }$ \\
\hline Mensalão & $\sqrt{ }$ & $\sqrt{ }$ \\
\hline Lula nos bastidores & $\sqrt{ }$ & $\sqrt{ }$ \\
\hline Influência da propaganda gratuita & $\sqrt{ }$ & $\sqrt{ }$ \\
\hline Criação de "conselhos populares" & $\sqrt{ }$ & \\
\hline Capa de Veja: "Eles sabiam de tudo" & $\sqrt{ }$ & \\
\hline Polarização pobres $\mathrm{x}$ ricos & $\sqrt{ }$ & $\sqrt{ }$ \\
\hline Tática do medo & $\sqrt{ }$ & $\sqrt{ }$ \\
\hline Possibilidade de fraude eleitoral & $\sqrt{ }$ & \\
\hline "Dilmês" & $\sqrt{ }$ & \\
\hline Fragilidade de Dilma & $\sqrt{ }$ & $\sqrt{ }$ \\
\hline Erro nos dados do PNAD & $\sqrt{ }$ & \\
\hline Uso da máquina pública & $\sqrt{ }$ & $\sqrt{ }$ \\
\hline Ameaças à governabilidade & $\sqrt{ }$ & $\sqrt{ }$ \\
\hline Críticas aos ataques ao Estado Islâmico & $\sqrt{ }$ & \\
\hline Emprego fantasma de Igor Rousseff & $\sqrt{ }$ & \\
\hline Papel da militância do PT & $\sqrt{ }$ & $\sqrt{ }$ \\
\hline Programas sociais & $\sqrt{ }$ & $\sqrt{ }$ \\
\hline Possibilidade de impeachment & $\sqrt{ }$ & \\
\hline Golpismo contra Dilma & $\sqrt{ }$ & $\sqrt{ }$ \\
\hline Vandalismo contra a Editora Abril & $\sqrt{ }$ & \\
\hline Vitória de Fernando Pimentel em Minas & $\sqrt{ }$ & $\sqrt{ }$ \\
\hline Controle social da mídia & & $\sqrt{ }$ \\
\hline
\end{tabular}

Fonte: Elaboração própria. 
Tabela 19 - Temas relativos à campanha de Marina Silva nas colunas de Pereira e Kramer

\begin{tabular}{|c|c|c|}
\hline Tema & Pereira & Kramer \\
\hline Contradições da "nova política" & $\sqrt{ }$ & $\sqrt{ }$ \\
\hline Dissidências no PSB & $\sqrt{ }$ & $\sqrt{ }$ \\
\hline Ameaças à governabilidade & $\sqrt{ }$ & $\sqrt{ }$ \\
\hline Fragilidade/choro & $\sqrt{ }$ & $\sqrt{ }$ \\
\hline Avião da campanha de Campos & $\sqrt{ }$ & \\
\hline Apoio de Neca Setúbal/banqueiros & $\sqrt{ }$ & \\
\hline Eduardo Campos citado na Lava-Jato & $\sqrt{ }$ & \\
\hline Pré-Sal & $\sqrt{ }$ & \\
\hline Posição contra o casamento gay & $\sqrt{ }$ & $\sqrt{ }$ \\
\hline Independência do Banco Central & $\sqrt{ }$ & \\
\hline Programa "escrito a lápis" & $\sqrt{ }$ & \\
\hline Misticismo & $\sqrt{ }$ & $\sqrt{ }$ \\
\hline Seringueiros contra Marina & $\sqrt{ }$ & \\
\hline Comparação com Jânio e Collor & $\sqrt{ }$ & $\sqrt{ }$ \\
\hline Resistência do empresariado & & $\sqrt{ }$ \\
\hline Inexperiência governamental & & $\sqrt{ }$ \\
\hline
\end{tabular}

Fonte: Elaboração própria.

Tabela 20 - Temas relativos à campanha de Aécio Neves nas colunas de Pereira e Kramer

\begin{tabular}{|c|c|c|}
\hline Tema & Pereira & Kramer \\
\hline Máquina partidária do PSDB & $\sqrt{ }$ & $\sqrt{ }$ \\
\hline Crise hídrica em São Paulo & $\sqrt{ }$ & \\
\hline Derrota de Aécio em Minas Gerais & $\sqrt{ }$ & \\
\hline Discordâncias internas no PSDB & $\sqrt{ }$ & $\sqrt{ }$ \\
\hline Caso do bafômetro & $\sqrt{ }$ & \\
\hline Aeroporto de Cláudio & $\sqrt{ }$ & \\
\hline Fim do fator previdenciário & $\sqrt{ }$ & \\
\hline Possível fim do PSDB & $\sqrt{ }$ & \\
\hline Legado do PSDB no governo & $\sqrt{ }$ & $\sqrt{ }$ \\
\hline Privatizações & $\sqrt{ }$ & $\sqrt{ }$ \\
\hline Andrea, irmã de Aécio & $\sqrt{ }$ & \\
\hline "Grosserias" de Aécio & $\sqrt{ }$ & \\
\hline Voto "silencioso" no PSDB & $\sqrt{ }$ & \\
\hline Aécio agressor de mulheres & $\sqrt{ }$ & \\
\hline
\end{tabular}

Fonte: Elaboração própria. 
Tabela 21 - Temas relativos à campanha de Daniel Scioli nas colunas de Morales Solá e Van der Kooy

\begin{tabular}{|c|c|c|}
\hline Tema & Morales Solá & Van der Kooy \\
\hline Eleições em Tucumán & $\sqrt{ }$ & $\sqrt{ }$ \\
\hline Suspeita de fraude eleitoral & $\sqrt{ }$ & $\sqrt{ }$ \\
\hline Relação Cristina-Scioli & $\sqrt{ }$ & $\sqrt{ }$ \\
\hline Perspectiva ruim da economia & $\sqrt{ }$ & $\sqrt{ }$ \\
\hline Juízes eleitorais & $\sqrt{ }$ & $\sqrt{ }$ \\
\hline Influência sobre a Justiça & $\sqrt{ }$ & $\sqrt{ }$ \\
\hline Fondos buitre ("fundos abutre") & $\sqrt{ }$ & $\sqrt{ }$ \\
\hline Campanha suja & $\sqrt{ }$ & $\sqrt{ }$ \\
\hline Guerra contra os meios & $\sqrt{ }$ & $\sqrt{ }$ \\
\hline Peronismo radical & $\sqrt{ }$ & \\
\hline Narcotráfico & $\sqrt{ }$ & \\
\hline Gastos desenfreados & $\sqrt{ }$ & $\sqrt{ }$ \\
\hline Corrupção no governo & $\sqrt{ }$ & $\sqrt{ }$ \\
\hline Tweets & $\sqrt{ }$ & $\sqrt{ }$ \\
\hline Fim do kirchnerismo & $\sqrt{ }$ & \\
\hline Bom-mocismo de Scioli & $\sqrt{ }$ & \\
\hline Inundações em Buenos Aires & $\sqrt{ }$ & \\
\hline Gildo Insfrán x Carlos Tevez & & \\
\hline Caso AMIA/Nisman/Stuso & & \\
\hline
\end{tabular}
Fonte: Elaboração própria.

Tabela 22 - Temas relativos à campanha de Mauricio Macri nas colunas de Morales Solá e Van der Kooy

\begin{tabular}{|c|c|c|}
\hline Tema & Morales Solá & Van der Kooy \\
\hline Governabilidade & $\sqrt{ }$ & $\sqrt{ }$ \\
\hline Desvalorização do peso & $\sqrt{ }$ & \\
\hline Caso Fernando Niembro & $\sqrt{ }$ & $\sqrt{ }$ \\
\hline Corrupção na oposição & $\sqrt{ }$ & \\
\hline
\end{tabular}
Fonte: Elaboração própria.

Tabela 23 - Temas relativos à campanha de Sergio Massa nas colunas de Morales Solá e Van der Kooy

\begin{tabular}{|c|c|c|}
\hline Tema & Morales Solá & Van der Kooy \\
\hline Governabilidade & $\sqrt{ }$ & \\
\hline
\end{tabular}




\subsection{Elementos comuns no enquadramento dos artigos}

Entman (1991, p. 6) afirma que "a essência do enquadramento é o dimensionamento - ampliar ou reduzir elementos da realidade retratada é torná-los mais ou menos salientes". Em outras palavras, não apenas o destaque dado a um aspecto da realidade, mas a sua omissão, ajudam a determinar, na lógica do enquadramento, a saliência daquele aspecto. No caso de uma cobertura eleitoral, as pesquisas desempenham papel determinante como justificativa para a maior ou menor importância atribuída a um candidato. Mesmo quando não são mencionadas, as pesquisas estão presentes, por exemplo, quando se decide falar de um determinado candidato, mais bem situado nessas mesmas pesquisas, e ignorar outro, que figura com menos intenções de voto.

Conforme exposto no item 4.2, Entman (2004) volta ao tema do enquadramento para definir seu conceito de forma mais precisa. Segundo o autor, os enquadramentos noticiosos podem se referir a três classes de objetos: eventos, questões e atores políticos. Os "atores" podem ser indivíduos ou instituições. Entman cita como exemplo de evento os atentados terroristas que atingiram os EUA em 11 de setembro de 2001; como exemplo de questão, a "guerra ao terror" encetada pelo governo americano após aqueles atentados; e como exemplo de atores Osama bin Laden, a Al Qaeda ou os Estados Unidos. Os objetos, como se depreende desses exemplos, podem figurar isolados ou simultaneamente num só enquadramento. Nos enquadramentos, Entman identifica quatro funções, relativas a esses objetos e necessárias para que o frame cumpra seu propósito persuasivo: a definição do problema; a identificação de suas causas; a elaboração de uma avaliação; e o endosso de soluções. Nem todas essas quatro funções precisam estar presentes para que se configure um enquadramento típico. Das funções do enquadramento, Entman define como as mais importantes a definição do problema - pois é ela que, em geral, determina o restante do enquadramento - e a solução, pois em geral o objetivo do enquadramento é promover determinado remédio. Diferentes definições levam a diferentes propostas de solução.

Da leitura dos artigos dos colunistas políticos brasileiros e argentinos nas respectivas campanhas presidenciais de 2014 e 2015, sobressaem alguns elementos em comum tanto em relação à definição do problema quanto ao remédio proposto. Um desses temas é o suposto desejo de mudança por parte da opinião pública. Tanto o 
desejo quanto a opinião pública são construções, uma vez que, como apontou Bourdieu, "a opinião pública não existe": o analista interpreta aquele que julga ser o sentimento da maioria da população, com base em elementos empíricos, entre os quais as pesquisas de opinião figuram como dos mais importantes.

Da mesma forma, a solução apontada pelos colunistas, de forma mais ou menos velada, é a troca de guarda no comando do Poder Executivo. Embora fossem múltiplas as candidaturas de oposição, no caso brasileiro apenas duas alternativas são apresentadas como viáveis - Marina Silva e Aécio Neves -, o que encontra justificação nos números das pesquisas. No panorama argentino, Joaquín Morales Solá é mais explícito na apologia do voto útil em favor de Mauricio Macri, enquanto Eduardo van der Kooy, no Clarín, se não chega a apontar claramente Macri como o candidaro mais viável, não deixa de registrar a dificuldade (apontada pelas pesquisas) de Sergio Massa para subir nas intenções de voto e impor-se como depositário das expectativas de mudança.

Procuramos detectar nas colunas de Dora Kramer, Merval Pereira, Eduardo van der Kooy e Joaquín Morales Solá funções e objetos de enquadramentos equivalentes aos propostos por Entman (2004). Nas Tabelas 24 a 27 é possível constatar semelhanças e diferenças nos enquadramentos relativos às respectivas campanhas eleitorais. No caso argentino, o papel preponderante da presidente Cristina Fernández de Kirchner motivou sua inclusão entre os atores dos enquadramentos. O mesmo não foi feito em relação ao ex-presidente Lula, no caso de Pereira, pelo número proporcionalmente menor de menções em suas colunas, se comparado às de Kramer ou mesmo às menções de Cristina nas colunas de Morales Solá e Van der Kooy.

Embora nas definições de funções e objetos dos colunistas brasileiros haja muitas semelhanças, os dois não enquadram os temas da campanha da mesma forma. Dora Kramer, por exemplo, atribui um papel muito mais preponderante a Lula, descrito como figura "ardilosa". Em uma de suas colunas, emprega os termos "vale tudo", "mentira", "manipulação", "traição" e "destruição de reputações" para os métodos de campanha de Lula e, por extensão, do PT:

Reza a história política dos últimos 12 anos que Luiz Inácio da Silva é o mais competente dos personagens que habitaram e transitaram pelo cenário do poder 
nesse período. Trata-se de uma avaliação que leva em conta resultados como parâmetro. Se nessa régua forem colocados quesitos relativos a limites éticos Lula ocuparia o pódio na categoria dos políticos ardilosos. (KRAMER, 11 set. 2014)

Empregando os conceitos propostos por Entman, procuramos identificar os objetos e funções dos enquadramentos dos colunistas brasileiros e argentinos nas respectivas campanhas eleitorais: os atores, eventos e questões mais frequentes abordados; os problemas definidos, as causas identificadas, as soluções endossadas e os julgamentos morais.

Nas Tabelas 24 e 25, analisamos os enquadramentos presentes nos textos dos colunistas brasileiros, Dora Kramer e Merval Pereira. Tanto a colunista de $O$ Estado de S. Paulo quanto o de $O$ Globo compartilham algumas ideias: que a morte de Eduardo Campos virou de cabeça para baixo uma campanha até então morna; que a ascensão de Marina Silva nas intenções de voto das pesquisas traduzia um anseio de mudança do eleitorado, provocado em boa medida pela crise econômica e pelos escândalos de corrupção; que as declarações e atos de Marina durante a campanha apresentavam contradições entre a "nova política" que ela afirmava representar e práticas que aparentemente não diferiam da "velha política"; que o medo de ser desalojado do poder levou o PT e Dilma Rousseff a uma "campanha suja", "de baixarias”, baseada na "tática do medo". Juízos morais que permitiriam contra-enquadramentos, como a hipótese de que a ascensão de Marina se devesse à comoção popular despertada pela morte inesperada de Eduardo Campos, foram minimizados e praticamente descartados. Entre as diferenças que puderam ser identificadas, podemos citar o papel de Lula como estrategista de campanha: Dora Kramer cita-o bem mais que Merval Pereira, o que nos levou a incluí-lo como ator relevante nos enquadramentos da colunista de $O$ Estado de S. Paulo. Ambos também ignoram ou dão muito pouco relevo a episódios da campanha que poderiam gerar enquadramentos desfavoráveis a Aécio Neves. Se Merval Pereira chega a mencionar alguns desses episódios, como o caso do aeroporto de Cláudio ou a recusa a fazer o teste do bafômetro ${ }^{73}$, Dora Kramer os omite por completo.

\footnotetext{
${ }^{73}$ Estes e outros episódios são contextualizados no Apêndice I.
} 
Tabela 24 - Funções e objetos dos enquadramentos nas colunas de Dora Kramer na campanha eleitoral brasileira de 2014, a partir dos critérios de Entman

\begin{tabular}{|c|c|c|c|}
\hline $\begin{array}{c}\text { Função do } \\
\text { enquadramento }\end{array}$ & $\begin{array}{l}\text { Questão: mudança } \\
\text { ou continuidade }\end{array}$ & $\begin{array}{l}\text { Evento: campanha } \\
\text { eleitoral } 2014\end{array}$ & $\begin{array}{l}\text { Atores: Dilma, Lula, } \\
\text { Marina, Aécio }\end{array}$ \\
\hline Problema & $\begin{array}{l}\text { "Clamor geral" por } \\
\text { reforma (apontado } \\
\text { pelas pesquisas) }\end{array}$ & $\begin{array}{c}\text { Ascensão inesperada } \\
\text { de Marina nas } \\
\text { pesquisas }\end{array}$ & $\begin{array}{l}\text { Ascensão inesperada } \\
\text { de Marina nas } \\
\text { pesquisas }\end{array}$ \\
\hline Causa & $\begin{array}{l}\text { Deterioração moral e } \\
\text { econômica do país }\end{array}$ & $\begin{array}{l}\text { Desejo de mudança } \\
\text { (apontado pelas } \\
\text { pesquisas) }\end{array}$ & $\begin{array}{l}\text { Desejo de mudança } \\
\text { (apontado pelas } \\
\text { pesquisas) }\end{array}$ \\
\hline Solução & Vitória da oposição & $\begin{array}{l}\text { Tornar a renovação } \\
\text { "factível e } \\
\text { compreensível" para a } \\
\text { maioria }\end{array}$ & $\begin{array}{l}\text { "Onda de razão" } \\
\text { tomar conta do } \\
\text { eleitorado }\end{array}$ \\
\hline Avaliação & $\begin{array}{l}\text { "Medo venceu a } \\
\text { esperança" }\end{array}$ & $\begin{array}{l}\text { Governo: tática do } \\
\text { medo. Oposição: falta } \\
\text { de combatividade }\end{array}$ & $\begin{array}{l}\text { Dilma: inescrupulosa; } \\
\text { Lula: ardiloso; Marina } \\
\text { incógnita; Aécio: } \\
\text { alternativa "racional" }\end{array}$ \\
\hline
\end{tabular}

Fonte: Elaboração própria a partir das colunas de Dora Kramer em O Estado de S. Paulo, ago.-nov. 2014.

Tabela 25 - Funções e objetos dos enquadramentos nas colunas de Merval Pereira na campanha eleitoral brasileira de 2014, a partir dos critérios de Entman

\begin{tabular}{|c|c|c|c|}
\hline $\begin{array}{c}\text { Função do } \\
\text { enquadramento }\end{array}$ & $\begin{array}{l}\text { Questão: mudança } \\
\text { ou continuidade }\end{array}$ & $\begin{array}{l}\text { Evento: campanha } \\
\text { eleitoral } 2014\end{array}$ & $\begin{array}{c}\text { Atores: Dilma, Aécio, } \\
\text { Marina }\end{array}$ \\
\hline Problema & $\begin{array}{l}\text { Anseio de mudança } \\
\text { (apontado pelas } \\
\text { pesquisas) }\end{array}$ & $\begin{array}{l}\text { Ascensão inesperada } \\
\text { de Marina nas } \\
\text { pesquisas }\end{array}$ & $\begin{array}{c}\text { Ascensão inesperada } \\
\text { de Marina nas } \\
\text { pesquisas }\end{array}$ \\
\hline Causa & $\begin{array}{l}\text { Piora da economia; } \\
\text { corrupção }\end{array}$ & $\begin{array}{l}\text { Anseio de mudança } \\
\text { (apontado pelas } \\
\text { pesquisas) }\end{array}$ & $\begin{array}{l}\text { Anseio de mudança } \\
\text { (apontado pelas } \\
\text { pesquisas) }\end{array}$ \\
\hline Solução & Derrota do governo & Derrota do governo & $\begin{array}{c}\text { Voto útil em Marina ou } \\
\text { Aécio }\end{array}$ \\
\hline Avaliação & $\begin{array}{c}\text { Qualquer que seja o } \\
\text { vencedor, país } \\
\text { irremediavelmente } \\
\text { dividido }\end{array}$ & $\begin{array}{c}\text { Nível baixo da } \\
\text { campanha. } \\
\text { "Estelionato eleitoral" } \\
\text { do PT }\end{array}$ & $\begin{array}{l}\text { Dilma: desleal. } \\
\text { Marina: contraditória. } \\
\text { Aécio: "mudança } \\
\text { segura" }\end{array}$ \\
\hline
\end{tabular}

Fonte: Elaboração própria a partir das colunas de Merval Pereira em O Globo, ago.-nov. 2014. 
Nas Tabelas 26 e 27, analisamos os enquadramentos presentes nos textos dos colunistas argentinos, Eduardo van der Kooy e Joaquín Morales Solá. Assim como ocorre com os colunistas brasileiros, é possível identificar ideias comuns nos dois autores. Ambos atribuem grande importância ao papel da presidente Cristina Fernández de Kirchner na campanha, salientando divergências entre ela e seu candidato, Daniel Scioli; apontam a dificuldade dos dois oposicionistas mais bem situados nas pesquisas, Mauricio Macri e Sergio Massa, em encarnar o suposto desejo de mudança da população (provocado, em grande medida, pela situação econômica e pela percepção de corrupção agravadas após mais de uma década de kirchnerismo) e atrair para si o voto útil que impediria a vitória de Scioli no primeiro turno; ressaltam a suposta "campanha suja", por parte da candidatura governista, para despertar no eleitorado o medo da mudança; levantam a possibilidade de fraude na eleição para beneficiar o governo, seja pelo uso da máquina governamental, seja por intimidação no dia do pleito, seja por pura e simples manipulação da contagem dos $\operatorname{votos}^{74}$. Da mesma forma que ocorreu com os colunistas brasileiros, Van der Kooy e Morales Solá minimizam ou ignoram aspectos da campanha que poderiam dar margem a enquadramentos desfavoráveis a Macri e Massa, como, no caso do primeiro, o envolvimento de seu aliado Fernando Niembro em um escândalo de corrupção. Entre as diferenças detectadas, pode-se citar a ênfase dada por Van der Kooy ao caso AMIA, em que a presidente foi acusada de tentar acobertar (supostamente por considerações de realpolitik) a responsabilidade iraniana em um atentado terrorista ocorrido em Buenos Aires em 1994. Van der Kooy retorna ao caso repetidas vezes ao longo da campanha, enquanto Morales Solá o ignora - uma evidência a mais de que o enquadramento, a decisão de ressaltar um ou outro assunto, é muitas vezes fruto de decisões conscientes que não dependem necessariamente da repercussão “espontânea” dos temas junto àquilo que se convencionou definir como opinião pública.

\footnotetext{
${ }^{74} \mathrm{O}$ segundo turno da eleição argentina, contrariando esses vaticínios pessimistas, transcorreu sem episódios de violência ou acusações de fraude relevantes.
} 
Tabela 26 - Funções e objetos dos enquadramentos nas colunas de Eduardo van der Kooy na campanha eleitoral argentina de 2015, a partir dos critérios de Entman

\begin{tabular}{|c|c|c|c|}
\hline $\begin{array}{c}\text { Função do } \\
\text { enquadramento }\end{array}$ & $\begin{array}{c}\text { Questão: mudança } \\
\text { ou continuidade }\end{array}$ & $\begin{array}{c}\text { Evento: campanha } \\
\text { eleitoral 2015 }\end{array}$ & $\begin{array}{c}\text { Atores: Cristina, } \\
\text { Scioli, Macri, Massa }\end{array}$ \\
\hline Problema & $\begin{array}{c}\text { Anseio de mudança } \\
\text { (apontado pelas } \\
\text { pesquisas) }\end{array}$ & $\begin{array}{c}\text { Campanha suja do } \\
\text { governo contra Macri, } \\
\text { risco de fraude e } \\
\text { violência }\end{array}$ & $\begin{array}{c}\text { Possibilidade de } \\
\text { vitória de Scioli no } \\
\text { primeiro turno }\end{array}$ \\
\hline Solução & $\begin{array}{c}\text { Economia sufocada, } \\
\text { escândalos, } \\
\text { insegurança, } \\
\text { narcotráfico }\end{array}$ & $\begin{array}{c}\text { Desespero do } \\
\text { kirchnerismo }\end{array}$ & $\begin{array}{c}\text { Descontentamento } \\
\text { passivo da população }\end{array}$ \\
\hline Fim do kirchnerismo & $\begin{array}{c}\text { Voto útil em Macri ou } \\
\text { Massa }\end{array}$ & $\begin{array}{c}\text { Voto útil em Macri ou } \\
\text { Massa }\end{array}$ \\
\hline Avaliação & $\begin{array}{c}\text { Qualquer que seja o } \\
\text { eleito, terá o fardo da } \\
\text { herança do cristinismo }\end{array}$ & $\begin{array}{c}\text { Debilidade da } \\
\text { democracia }\end{array}$ & $\begin{array}{c}\text { Crioli: sem autonomitária. } \\
\text { Macri: } \\
\text { ziguezagueante. } \\
\text { Massa: propositivo, } \\
\text { mas aventura eleitoral }\end{array}$ \\
\hline Fonte: Elaboração própria a partir das colunas de Eduardo van der Kooy no Clarín, ago.-nov. 2015.
\end{tabular}

Tabela 27 - Funções e objetos dos enquadramentos nas colunas de Joaquín Morales Solá na campanha eleitoral argentina de 2015, segundo os critérios de Entman

\begin{tabular}{|c|c|c|c|}
\hline $\begin{array}{c}\text { Função do } \\
\text { enquadramento }\end{array}$ & $\begin{array}{l}\text { Questão: mudança } \\
\text { ou continuidade }\end{array}$ & $\begin{array}{l}\text { Evento: campanha } \\
\text { eleitoral } 2015\end{array}$ & $\begin{array}{l}\text { Atores: Cristina, } \\
\text { Scioli, Macri, Massa }\end{array}$ \\
\hline Problema & $\begin{array}{l}\text { Anseio de mudança } \\
\text { (apontado pelas } \\
\text { pesquisas) }\end{array}$ & $\begin{array}{l}\text { Campanha do medo, } \\
\text { risco de fraude } \\
\text { eleitoral }\end{array}$ & $\begin{array}{l}\text { Possibilidade de } \\
\text { vitória de Scioli no } \\
\text { primeiro turno }\end{array}$ \\
\hline Causa & Piora da economia & $\begin{array}{l}\text { Desespero do } \\
\text { kirchnerismo }\end{array}$ & Anseio de mudança \\
\hline Solução & Fim do kirchnerismo & Derrota do governo & Voto útil em Macri \\
\hline Avaliação & $\begin{array}{l}\text { Cansaço do eleitorado } \\
\text { por doze anos de } \\
\text { kirchnerismo }\end{array}$ & $\begin{array}{l}\text { Perspectiva de } \\
\text { mudança triunfa sobre } \\
\text { a campanha do medo }\end{array}$ & $\begin{array}{l}\text { Cristina: agressiva. } \\
\text { Scioli: tutelado pela } \\
\text { presidente. Macri: } \\
\text { mudança. Massa: } \\
\text { estorvo }\end{array}$ \\
\hline
\end{tabular}




\subsection{Enquadramentos relacionados às pesquisas}

Nos textos dos quatro colunistas foi possível identificar, a partir dos temas listados no capítulo, uma série de enquadramentos, alguns relacionados às pesquisas eleitorais, outros não. Aqui vamos nos restringir àqueles que são direta ou indiretamente influenciados pelos números das pesquisas.

\section{a) Omissão dos candidatos mal situados nas pesquisas.}

A primeira característica em comum que chama a atenção nos textos de Kramer, Pereira, Van der Kooy e Morales Solá é a negligência quase total dos candidatos considerados sem chance de vitória. Embora a eleição argentina tivesse seis candidatos, e a brasileira, 11, apenas três são mencionados sistematicamente nos textos analisados: Marina Silva, Dilma Rousseff e Aécio Neves, no caso brasileiro, e Daniel Scioli, Mauricio Macri e Sergio Massa, no caso argentino. Os candidatos Eduardo Jorge, Pastor Everaldo e Luciana Genro, no Brasil, e Margarita Stolbizer, Adolfo Rodríguez Saá e Nicolás del Caño, na Argentina, recebem apenas breves menções, relativas à transferência de seus votos ou a intervenções nos debates televisivos do primeiro turno. Os candidatos ditos "nanicos" não são os únicos a sofrer desse ostracismo: no caso brasileiro, até mesmo o candidato Aécio Neves, terceiro colocado nas pesquisas, tem uma redução drástica no número de citações no período em que as pesquisas pareciam indicar uma polarização da disputa entre Dilma Rousseff e Marina Silva. Entre 7 e 21 de setembro de 2014, Dora Kramer cita Dilma nove vezes, Marina seis e Aécio apenas três vezes em suas colunas; entre 13 e 26 de setembro, Merval Pereira cita Dilma onze vezes, Marina também onze e Aécio apenas oito vezes.

Essa opção é claramente influenciada pelo resultado das pesquisas e nelas encontra seu álibi. Dora Kramer cita apenas uma vez, em 52 colunas, outros candidatos além dos três "principais" - ainda assim, apenas após a realização do primeiro turno, quando já estavam eliminados da disputa: "Eduardo Jorge, sucesso entre a juventude, posicionou o PV no campo da oposição. O governo contou com a declaração de voto de Luciana Genro, do PSOL", escreve, em 9 de outubro - citação ainda mais incongruente por falar em um "sucesso entre a juventude", no caso do candidato verde, que 
aparentemente não estava fundamentado em qualquer dado de pesquisa ou número de votação e tampouco fora citado em qualquer coluna anterior da própria autora.

Nos artigos de Merval Pereira, apenas dois outros candidatos são citados, uma única vez cada um: Pastor Everaldo, em 27 de agosto - para atribuir sua queda nas pesquisas, da faixa dos $3 \%$ para 1\%, à entrada de Marina, uma evangélica como ele, na disputa - e Luciana Genro, a 3 de outubro (dois dias antes do primeiro turno), para fazer referência a uma crítica desta a Dilma Rousseff durante um debate televisivo. Na Argentina, Van der Kooy e Morales Solá são ligeiramente mais generosos com os outros três candidatos. Margarita Stolbizer é mencionada quatro vezes por Morales Solá. As duas primeiras, em agosto, mencionam a condenação de Stolbizer à suposta fraude ocorrida na eleição para governador na província de Tucumán. Na terceira, citando a líder radical Elisa Carrió, que pregava o voto útil em favor de Mauricio Macri, afirma:

[E]1 voto a Margarita Stolbizer, dice [Elisa Carrió], es "el voto Poncio Pilatos", aludiendo a los que se lavan las manos dejando tranquila su conciencia ideológica. (MORALES SOLÁ, 14 out. 2015)

Por fim, em 28 de outubro, dois dias após o primeiro turno, Morales Solá discute a transferência de seus votos para Macri. Nas duas primeiras o contexto é desfavorável a Daniel Scioli; nas duas últimas é favorável a Mauricio Macri.

Não surpreende que Marina Silva seja a candidata mais citada nos artigos de Merval Pereira, considerando que girou em torno dela, em grande parte, a campanha a partir de 13 de agosto: durante o período que antecedeu o primeiro turno, por sua condição (em razão das pesquisas) de forte candidata ao segundo turno; e depois de 5 de outubro, em virtude do peso que seu apoio a Aécio Neves poderia representar na transferência de votos para o candidato do PSDB.

\section{b) Omissão das eleições estaduais/provinciais e legislativas.}

Outro efeito que pode, pelo menos em parte, ser atribuído às pesquisas eleitorais é a omissão, nas colunas de $O$ Estado de S. Paulo, O Globo, Clarín e La Nación, das 
campanhas para os governos estaduais ou provinciais e para a Câmara dos Deputados e o Senado Federal. Essa omissão espelha a forma como a imprensa trata dessas eleições ao divulgar pesquisas: os levantamentos referentes aos pleitos regionais majoritários (governador/senador) ocupam um espaço secundário na TV e nos jornais, sendo geralmente divulgados no dia seguinte à publicação dos números das pesquisas para a eleição presidencial; e são bem mais escassas as sondagens a respeito das preferências para as eleições legislativas. Não é objetivo deste trabalho realizar uma comparação quantitativa das pesquisas referentes a eleições majoritárias ou proporcionais, mas um indício da enorme diferença é o fato de nenhum dos grandes jornais ter dedicado manchete principal de primeira página, ao longo da campanha, a pesquisas que tentassem estimar o tamanho da bancada de cada partido após as eleições legislativas.

Uma acusação feita constantemente à imprensa, na cobertura política, é de conceder espaço exagerado à eleição presidencial, deixando em segundo plano os demais pleitos simultâneos. Num regime democrático de separação e harmonia entre os três poderes, em tese, a eleição para o Legislativo tem a mesma importância que aquela para o Executivo. Embora as características dos sistemas políticos brasileiro e argentino fortaleçam o papel do presidente da República, como chefe do Executivo ${ }^{75}$, na determinação das diretrizes do governo ${ }^{76}$, o Congresso não é um mero ratificador das ordens presidenciais, e a formação, pela coligação no poder, de uma maioria parlamentar nas eleições constitui um apoio importante para a governabilidade.

Pesquisar as preferências para o Legislativo, reconhecidamente, é bem mais difícil. A Câmara dos Deputados brasileira tem 513 membros, com renovação total a cada quatro anos, e a argentina, 257, com renovação de metade a cada dois anos. Estimar com precisão, por meio de pesquisa por amostragem, que composição terá o Congresso é um desafio estatístico bem maior do que apontar o candidato mais votado numa eleição nacional majoritária, como são as presidenciais brasileira e argentina.

\footnotetext{
${ }^{75}$ ANASTÁCIA, RANULFO e SANTOS (2004) estudaram a questão da governabilidade nas democracias sul-americanas.

${ }^{76}$ No Brasil, a possibilidade de editar "medidas provisórias", com vigência imediata mesmo antes da apreciação pelo parlamento, propicia ao Executivo grande latitude de ação. Criadas pela Constituição de 1988, são uma espécie de "filhote" dos "decretos-leis" dos tempos da ditadura, que permitiam ao presidente da República governar sem depender do Congresso.
} 


\section{c) Pregação do voto útil em favor da alternativa oposicionista com mais} chances de vitória.

O "voto útil" (ou "voto tático", ou ainda "voto estratégico") é uma característica das eleições majoritárias que deve muito de sua existência às pesquisas eleitorais. Tratase da opção do eleitor por votar não no candidato que prefere, mas naquele que julga ter mais chances de vencer a eleição (o bandwagon effect). Essa percepção das probabilidades do candidato só pode ser obtida através dos meios de comunicação, via noticiário ou campanha eleitoral, ou do contato empírico com outros eleitores. Fica evidente a importância das pesquisas na decisão do voto útil.

Nos sistemas eleitorais de turno único (maioria simples), o voto útil tende a concentrar os sufrágios em um dos dois candidatos com mais chances. Duverger (1972) demonstrou que esse tipo de sistema eleitoral tende a engendrar o bipartidarismo. $\mathrm{O}$ motivo é que, numa eleição de um só turno (em que ganha o candidato com mais votos, qualquer que seja o percentual atingido), as forças políticas tendem a se agrupar para não desaparecerem do tabuleiro político; por sua vez, no sistema com eleição em dois turnos (ou seja, que exige que o vencedor atinja a maioria absoluta dos votos), tende-se a um multipartidarismo de coalizão. A razão é que, no primeiro turno, os partidos podem "tentar a sorte", para depois barganhar seu apoio a um dos candidatos finalistas. O segundo turno se torna assim, uma disputa entre coalizões formadas pelos finalistas com os derrotados do primeiro turno que vierem a apoiá-los.

A entrada de Marina Silva na campanha presidencial brasileira e o bom desempenho de Sergio Massa na campanha argentina embaralharam os cálculos dos analistas. Tanto Marina quanto Massa “roubavam" votos, em alguma medida, dos candidatos de governo e da oposição considerados favoritos antes do início da campanha (Dilma e Aécio, no Brasil; Scioli e Macri, na Argentina). Isso levou os colunistas a propor o voto útil em favor do candidato de oposição com mais chances de derrotar o governo num eventual segundo turno.

No caso argentino, em diversos momentos da campanha do primeiro turno Morales Solá ressaltou o tema da transferência de votos de Sergio Massa para Macri. 
¿Qué es (o qué significa) el voto útil del que tanto se habla? Significa que un sector del electorado, que vacila entre Macri y Massa, se volcaría por el candidato con más posibilidades de acorralar al oficialismo, aunque no sea el que más le guste. Macri es, por razones obvias, el profeta más interesado en propagar la necesidad del voto útil. (MORALES SOLÁ, 11 out. 2015)

Macri es el mayor propagador de voto útil. ¿Para qué votarlo a Massa si un ballotage ${ }^{77}$ sólo será posible entre él y Scioli? ¿Para qué, si la división del voto opositor sólo beneficiaría a Scioli? ¿Por qué no votar al menos malo y no al que algunos sectores sociales consideran el mejor, pero con escasas o nulas posibilidades de acceder a una segunda vuelta? (MORALES SOLÁ, 14 out. 2015)

Eduardo van der Kooy toca no tema do voto útil com menos ênfase, e sem tomar partido claro por Macri ou Massa. A preocupação dos dois colunistas, naturalmente, se acentua na medida da aproximação da data do primeiro turno, e diante de pesquisas que indicam uma probabilidade razoável de vitória do governista Daniel Scioli no primeiro turno.

Mauricio Macri y Sergio Massa corren detrás del mismo objetivo: la captación del llamado voto útil. De aquellos ciudadanos que se muestran proclives a querer clausurar los doce años del período kirchnerista. (VAN DER KOOY, 7 out. 2015)

Macri parece dedicado ahora a pulsear más con Massa que con Scioli. A diez días de la votación no consiguió aún dos objetivos de base: movilizar el llamado "voto útil" y perforar la clientela del candidato del FR. (VAN DER KOOY, 14 out. 2015)

A razão para isso se encontra na lógica das regras eleitorais argentinas. As pesquisas apontavam que Scioli estava muito próximo de obter $40 \%$ dos votos no primeiro turno e dez pontos percentuais de vantagem sobre Macri. Portanto, Massa poderia estar recebendo votos que seriam cruciais para Macri garantir a ocorrência de um segundo turno. Porém, ao mesmo tempo, Massa também "roubava" votos de Scioli, diminuindo sua chance de atingir 40\% (o candidato do governo não passaria de $36 \%$ ). Morales Solá intensifica suas referências ao voto útil nos dias que antecedem o primeiro turno, sempre apresentando os argumentos como de Macri, não seus. Porém, o enquadramento é do colunista.

\footnotetext{
77 "Segundo turno", em espanhol. O termo vem do francês ballottage e designa, mais precisamente, a situação onde nenhum candidato alcança a maioria absoluta, forçando, quando as regras eleitorais assim exigem, um novo escrutínio.
} 
No Brasil, Dora Kramer faz uma breve referência ao tema, em 2 de setembro, para dizer que no horário eleitoral gratuito Aécio Neves criticou a ideia de um voto útil em Marina. Nas colunas de Merval Pereira a argumentação pelo voto útil leva a certo contorcionismo lógico. Nos dias que sucederam a morte de Eduardo Campos, o colunista de $O$ Globo parecia acreditar que a ascensão de Marina nas pesquisas pudesse desencadear, paradoxalmente, o voto útil em favor de Aécio - argumento difícil de conciliar com a lógica, uma vez que qualquer manancial de votos úteis para Aécio teria que vir de algum lugar, e esse lugar não poderia ser nem o eleitorado de Dilma (não faria sentido quem apoiasse Dilma votar em Aécio, ameaçando, assim a posição da própria Dilma), nem o de Marina (pois, a acreditar nas pesquisas, ela vinha ganhando votos, e não perdendo), nem o dos candidatos ditos "nanicos" (por insuficientes), restando, então, como única opção a Aécio roubar votos de si mesmo. Ao mesmo tempo, em meio à suposta "onda" marinista, o colunista de $O$ Globo leva em conta a hipótese do voto útil em favor de Marina, propondo até que Aécio Neves modere seus ataques contra a candidata do PSB para não inviabilizar um eventual apoio a ela no segundo turno. Pereira chega a propor o voto útil em Aécio para... fortalecer seu poder de barganha, como terceiro colocado, num "provável governo Marina”. A lógica desse raciocínio também nos foge à compreensão, uma vez que o eleitor de Marina, por definição, vota em Marina, por desejar sua vitória, e não cogitaria votar em seus adversários apenas para lhes conferir poder de barganha.

O receio de que Marina possa chegar ao segundo turno derrotando Aécio Neves, com chances de vencer Dilma, pode desencadear uma espécie de "voto útil" daqueles que não estariam confortáveis com sua vitória (...). Mas o voto útil também pode beneficiar a candidatura de Marina, na medida em que ela surja como a única que pode derrotar Dilma num segundo turno. Caso Aécio não cresça a ponto de também surgir como uma alternativa no segundo turno, ele pode perder eleitores ainda no primeiro turno para Marina, num voto útil contra o PT. (PEREIRA, 20 ago. 2014)

O voto útil em Marina, para garanti-la no segundo turno ou forçar uma derrota do PT já no primeiro, pode ser um tiro no pé nos eleitores que temem Marina presidente mas não querem Dilma reeleita. Nesse caso, fortalecer a votação do terceiro colocado é impor uma negociação política que demarcará um provável governo Marina. (PEREIRA, 31 ago. 2014)

Em todos esses casos, fica clara a influência das pesquisas nos enquadramentos e "julgamentos morais" (para usar o conceito de Entman) dos colunistas em relação às atitudes dos candidatos na campanha eleitoral. Tanto no 
caso de Pereira quanto, em especial, no de Morales Solá, esses enquadramentos se justificam numa lógica cuja prioridade é a derrota do partido no poder, qualquer que seja o oposicionista que venha a triunfar.

\section{d) Atribuição ao eleitorado de anseios, como o "anseio de mudança".}

"Mudança" tem sido, nos últimos anos, um dos principais motes de discursos eleitorais em diversos países. Um dos principais slogans da vitoriosa campanha de Barack Obama à presidência dos Estados Unidos, em 2008, foi Change we can believe in ("Mudança em que dá para acreditar"). Em geral, a palavra integra os slogans de partidos de oposição - por definição, o objetivo deles é mudar o status quo -, embora hoje até mesmo partidos no poder se apropriem da ideia: a campanha de Cristina Fernández à reeleição, em 2011, falava em "mudança com continuidade"; o marqueteiro de Dilma Rousseff, João Santana, empregou a mesma expressão em maio de 2014, em discurso no Encontro Nacional de Comunicação do Partido Comunista do Brasil, em São Paulo. ${ }^{78}$

No contexto de uma campanha eleitoral, o termo é apresentado sob um viés positivo - mudança para melhor - e tende a ter maior penetração em conjunturas econômicas desfavoráveis. Algumas pesquisas, durante a campanha eleitoral, buscaram medir o grau de "desejo de mudança" da população. Em maio de 2014, o Datafolha divulgou levantamento segundo o qual "74\% dos eleitores dizem querer mudanças na forma como o país é governado". ${ }^{79}$ Os quatro colunistas analisados fazem referência a esse suposto anseio ao longo da campanha eleitoral, com ou sem números de pesquisas a embasar a argumentação:

Já são $76 \%$ dos eleitores detectados pelo Datafolha que querem mudanças na condução do país, o que não favorece a continuidade. (PEREIRA, 20 ago. 2014)

Com relação a Marina, sua votação me parece fruto do despertar de um eleitorado que estava em busca de um candidato que se identificasse com o desejo de mudança registrado em todas as pesquisas. (PEREIRA, 27 ago. 2014)

\footnotetext{
78 MOTA (2014).

${ }^{79}$ Valor Econômico, 9 mai. 2014.
} 
Marina fugiu desse enquadramento. Numa perspectiva mais realista, isso pode ser visto como ausência de clareza e consistência. Mas, do ponto de vista do eleitor ávido pelo "novo" pode ser percebido como sinal de uma visão diferente. (KRAMER, 28 ago. 2014)

[U]na mayoría social pide, con menor o mayor intensidad, un cambio político después de 12 años de kirchnerismo. (MORALES SOLÁ, 26 out. 2015)

Macri parece haber sabido exprimir el descontento subterráneo y pasivo de la sociedad con el Gobierno. (VAN DER KOOY, 26 out. 2015)

Según esos analistas de opinión pública, es más importante para la mayoría de los votantes la promesa de un cambio de políticas y de estilo de Macri que el miedo que propaga el oficialismo sobre una eventual presidencia del líder de Cambiemos. (MORALES SOLÁ, 11 nov. 2015)

Tanto Pereira quanto Morales Solá chegam, numa única ocasião cada um, a apontar uma contradição nas pesquisas. No Brasil, números contraditórios indicavam, ao mesmo tempo, que os entrevistados queriam mudança e que estavam satisfeitos com a vida atual. Merval Pereira, porém, enquadra essa contradição de maneira favorável a Aécio - ele seria o candidato ideal, por encarnar ao mesmo tempo a mudança (em relação a Dilma) e a estabilidade (em relação a Marina). Na Argentina, as sondagens indicavam, ao mesmo tempo, que o eleitorado queria mudança $e$ queria a continuidade do peronismo (representado por Daniel Scioli).

O cientista político Geraldo Tadeu Monteiro, do Iuperj, ampliando sua análise sobre os dados das pesquisas do Ibope e Datafolha, acha que Aécio surfa numa onda de "mudança com segurança" que conjuga dados aparentemente inconsistentes entre os $73 \%$ que desejam mudanças (Datafolha) e os $80 \%$ que se dizem satisfeitos ou muito satisfeitos com a vida que levam hoje (Ibope). (PEREIRA, 16 out. 2014)

Será una elección, en primer lugar, que tendrá sólo dos candidatos, Scioli y Macri, y que deberá dilucidar qué espolea más al electorado: si la vieja confianza de una mayoría social en el control del poder por parte del peronismo (el porcentaje ronda en esa cuestión el 60 por ciento de los votos) o si prevalece el amplio anhelo social (de más del 60 por ciento, según los votos de la víspera) de un cambio claro en la conducción del poder. (MORALES SOLÁ, 26 out. 2015)

\section{e) Afirmação de ideias baseadas em pesquisas “ocultas", não publicadas.}

Nem toda pesquisa eleitoral é divulgada. Os comitês de campanha dos candidatos encomendam pesquisas qualitativas, pesquisas telefônicas e outros levantamentos que sirvam de subsídios para orientação do tom dos spots publicitários. 
Muitas dessas sondagens não podem ser divulgadas, por não atenderem aos critérios impostos pela legislação eleitoral, abordados em capítulo anterior. Mas estariam sendo usadas pelos colunistas em suas análises? E em caso afirmativo, estariam contribuindo de alguma maneira para uma compreensão melhor do comportamento do eleitorado?

A resposta à primeira pergunta é sim - tanto Merval Pereira quanto Joaquín Morales Solá citam, em alguns momentos, outras pesquisas além daquelas realizadas pelas principais empresas do setor. Porém, da análise dos textos, não nos pareceu que elas contribuam para que os colunistas entendam melhor as tendências do eleitor. São usadas, na verdade, para reforçar ainda mais os enquadramentos dos autores.

Ao mencionar essas pesquisas "ocultas", os colunistas criam a impressão de estar levando o leitor aos bastidores da campanha, seja antecipando os números de pesquisas ainda não divulgadas, seja insinuando o conhecimento de informações que não viriam a público. Mas esse suposto acesso é falacioso. ${ }^{80}$ Em primeiro lugar, porque se houvesse nas pesquisas "internas" dos partidos alguma informação ausente das pesquisas divulgadas ao público em geral, seria preciso admitir algo de errado com estas ou com aquelas. Morales Solá chega a afirmar, no final da campanha do primeiro turno, que os levantamentos telefônicos feitos pela campanha de Macri apontavam um crescimento do candidato da oposição que as pesquisas convencionais não poderiam detectar, em razão de seu processo de elaboração supostamente mais lento.

Sondagens telefônicas nos últimos dias sugerem que Marina estaria empatada tecnicamente com o tucano, mas à frente numericamente. Se, mesmo assim, Aécio mantiver seu índice, é sinal de que tem votos cristalizados. (PEREIRA, 15 ago. 2014)

Grosso modo os índices confirmam o que as consultas telefônicas informavam diariamente às campanhas (...) (KRAMER, 27 ago. 2014)

Es cierto, de todos modos, que en las últimas 72 horas las mediciones telefónicas comenzaron a registrar un crecimiento de Macri, que las encuestas presenciales no pudieron verificar por su propia y lenta dinámica. De hecho, la encuesta de Poliarquía se cerró el martes pasado y las novedades telefónicas comenzaron a producirse en la tarde del miércoles. (MORALES SOLÁ, 11 out. 2015)

\footnotetext{
${ }^{80}$ Entman (2004, p. 71-72) menciona um "truque" análogo na cobertura de política internacional nos Estados Unidos: a referência a fontes que, privadamente, fariam comentários diferentes daquilo que é dito em público. O próprio vazamento da informação, proposital, desmente o caráter supostamente "privado" desses comentários.
} 
¿La Presidenta estaba preparada, entonces, para perder? De ninguna manera. Sus encuestas de los últimos días denunciaban que Scioli iría sin remedio, aunque con clara ventaja, a un balotaje contra Mauricio Macri. Pero que Aníbal y los camporistas se afianzarían en territorio bonaerense. (VAN DER KOOY, 1 nov. 2015)

Morales Solá emprega sistematicamente o anonimato ao se referir aos encuestadores, e, como mencionado mais acima, cita nominalmente apenas uma empresa de pesquisas, a Poliarquía, de quem o La Nación é cliente. O colunista argentino chega a usar o anonimato para se referir a uma empresa, dois dias antes do segundo turno da eleição, transmitindo a impressão de saber de um dado desconhecido do público:

Una medición de una encuestadora nueva, que estuvo muy cerca de los resultados del 25 de octubre, amplía la ventaja [de Macri] al $16 \%{ }^{81}$. (MORALES SOLÁ, 20 nov. 2015)

Os grupos focais realizados pelos partidos ganham uma única menção, em coluna de Pereira:

\begin{abstract}
Nas pesquisas internas do PSDB há a identificação de uma perda de substância na votação de Marina. Neste momento, estaria saindo mais voto em Marina do que entrando. $\mathrm{O}$ eleitor tem pouca permanência na escolha de Marina. A propaganda de Marina indignada, citando Dilma diretamente e quase chorando, não pegou bem entre os eleitores que participaram de uma pesquisa qualitativa realizada para o PSDB. (...) Teve eleitor que achou exagerado, acima do tom, e quem fizesse o seguinte comentário: quero ter um presidente frágil, que chore? Quero cuidar da minha presidente ou quero que o presidente cuide de mim? (PEREIRA, 18 set. 2014)
\end{abstract}

Nossa análise indica, portanto, que o uso de outras pesquisas nas avaliações da campanha não contribui para um entendimento melhor de como pensa o eleitorado, uma vez que esse uso é esparso, anedótico e não-sistemático. Embora os grupos focais possam ser um instrumento interessante de análise - desde que realizados com independência em relação aos partidos -, eles são ignorados pelos meios de comunicação, reforçando a hipótese de que as pesquisas são usadas como elemento de

\footnotetext{
${ }^{81}$ Macri venceu por uma diferença de 2,8 pontos percentuais.
} 
construção da realidade, agendamento e enquadramento da cobertura da campanha, e não de análise efetiva do comportamento do eleitor.

\section{f) Crença na metodologia das pesquisas.}

Ávidos utilizadores de pesquisas em suas análises, os colunistas naturalmente não podem questionar seus números, sob pena de pôr em xeque, ao mesmo tempo, grande parte daquilo que escrevem. Isto se verifica em suas menções eventuais à credibilidade das pesquisas como um todo, sob pena de levar a eventuais incoerências na argumentação. Dora Kramer, em O Estado de S. Paulo, mostra-se entusiasta das pesquisas, ressaltando que os acertos dos levantamentos tendem a ser esquecidos, enquanto os erros têm maior repercussão:

Toda eleição é a mesma coisa: os acertos das pesquisas são esquecidos e seus desacertos superdimensionados. O problema não está na amostragem das tendências - todas captadas nesta eleição particularmente imprevisível -, mas na expectativa de que elas adivinhem o resultado das urnas. Por mais que se diga que refletem um momento, as pessoas insistem em vê-las como bolas de cristal e desconsideram os demais fatores. O principal deles, as decisões de última hora. (KRAMER, 16 out. 2014)

Embora reconheça que todas as empresas de pesquisas, "até as mais sérias", erraram os resultados do primeiro turno da eleição argentina (Mauricio Macri teve uma votação muito maior que o previsto), Joaquín Morales Solá continua a se servir delas em suas colunas anteriores ao segundo turno (em que Macri derrotaria Scioli, mas por uma diferença bem inferior à indicada pelas pesquisas). O colunista do La Nación chega a atribuir o erro das pesquisas a um suposto medo dos entrevistados de declarar voto contra "um governo disposto a vingar-se" usando "os serviços de inteligência".

Es cierto que todas las agencias de encuestas, aun las más serias, se equivocaron por lejos con respecto a los resultados. Esta vez no es su culpa. Los corrimientos sociales de última hora son imposibles de detectar a tiempo. Las propias encuestas de Macri pronosticaron un triunfo de Scioli por ocho puntos, un supuesto error de más de cinco puntos (...). Puede suceder que en la Argentina haya influido también el miedo de los encuestados hacia un gobierno siempre dispuesto a vengarse, que arrastra la imagen de usar a los servicios de inteligencia para cualquier cosa. (MORALES SOLÁ, 27 out. 2015) 


\section{Conclusões}

Procuramos neste trabalho investigar a hipótese de que as análises das pesquisas de intenção de voto feitas pelos meios de comunicação não propiciam uma melhor compreensão do comportamento do eleitorado por serem, na verdade, instrumentos utilizados no agendamento do debate político e no enquadramento das questões a que esses meios de comunicação desejam conferir relevo. Nossa hipótese surgiu da percepção de que a cobertura da eleição presidencial brasileira de 2014 não deu conta adequadamente da interpretação dos números das pesquisas de intenção de voto, a partir da morte de Eduardo Campos e da entrada de Marina Silva na campanha. A rápida ascensão de Marina, a poucas semanas do pleito - alterando um quadro que até então (a acreditar nas pesquisas) apontava para a reeleição da presidente Dilma Rousseff ainda no primeiro turno -, levou diversos analistas a vaticinar um segundo turno entre Dilma e Marina, em que esta última seria favorita; em determinado momento, alguns chegaram a prever a vitória de Marina ainda no primeiro turno. Esses prognósticos, que predominavam pouco mais de uma semana antes da eleição, foram desmentidos no dia do primeiro turno, quando a contagem dos votos apontou um segundo turno entre Dilma e Aécio Neves, tendo Marina ficado num distante terceiro lugar. A uma semana da votação, nenhuma análise nos meios de comunicação antecipou esse desfecho; embora não seja atribuição do jornalismo prever com precisão o futuro, impossível não deixar de conjecturar se as pesquisas de intenção de voto, em vez de ajudar na compreensão do comportamento do eleitorado, ao contrário, foram empregadas como elemento de persuasão.

A proximidade de outra campanha presidencial em país vizinho, cujas características conjunturais guardavam semelhanças visíveis com as brasileiras, ensejou a extensão do estudo à eleição argentina de 2015. Para validar o estudo comparado como método de pesquisa, recorremos ao quadro referencial proposto por Hallin e Mancini (2004), que, embora tenha sido criado pensando sobretudo no contexto dos países desenvolvidos do Hemisfério Norte, vem sendo aplicado com adaptações ao contexto mediático de outras regiões do globo, entre elas a América Latina.

Além dessa validação do estudo comparado, debruçamo-nos sobre questões metodológicas e jurídicas relativas às pesquisas, suscetíveis de influenciar a forma como 
elas são apresentadas pela imprensa. Os jornalistas estão sujeitos a certas restrições por exemplo, quanto à forma e ao período de apresentação dos números - incluídas na legislação eleitoral no intuito de impedir manipulações, e criadas diante da percepção da inegável influência da divulgação de intenções de voto, verdadeiras ou não, sobre as decisões do eleitorado. Comparamos a legislação de dezoito países latino-americanos para avaliar se Brasil e Argentina faziam figura de regra ou exceção em relação às demais nações da região. Também julgamos necessário estudar o estado da arte no debate sobre a validade das pesquisas como instrumento científico de mensuração das preferências de populações em geral. Entre outros problemas que vêm sendo discutidos, nos campos da estatística, da política e do jornalismo, encontramos a falta de transparência na liberação dos "microdados", que permitiria identificar possíveis violações das normas consagradas entre os estatísticos profissionais; e a dificuldade na elaboração de amostragens por quotas capazes de reproduzir fielmente o comportamento de um eleitorado visto como cada vez mais volátil em vários países. Essa dificuldade estaria por trás de diversas discrepâncias, percebidas como erros, entre resultados de pesquisas às vésperas de eleições e o resultado efetivo desses pleitos.

Diante do grande número de textos jornalísticos que analisaram a campanha, em meios impressos, televisão, rádio e internet, era preciso definir um recorte de pesquisa. Selecionamos como corpus de pesquisa os mais importantes colunistas políticos de jornais de referência, dois para cada país pesquisado, com presença em diferentes plataformas e cujas colunas abordassem com regularidade a eleição presidencial. Procedemos uma análise da pertinência dessa escolha, avaliando a relevância de 170 textos em relação aos temas debatidos durante as duas campanhas eleitorais. O critério de relevância adotado levou em conta as menções à campanha, aos candidatos a presidente e às pesquisas eleitorais, concluindo-se que virtualmente todas as colunas analisadas faziam referência a um ou mais desses aspectos.

Assegurada a pertinência e a relevância dos textos, procedeu-se a uma leitura crítica com base nos critérios propostos por Entman (2004) para a identificação de enquadramentos noticiosos. Seguindo-se os conceitos por ele definidos, buscaram-se os atores, as questões e os eventos objetos dos enquadramentos, passando-se em seguida à identificação das funções relacionadas a esses objetos - problemas definidos, causas apontadas, soluções propostas, avaliações e julgamentos morais. 
Desst análise, concluímos que os enquadramentos dos colunistas políticos dos dois países, nas campanhas eleitorais estudadas, empregam constantemente as pesquisas. Entre outros usos, os números de intenções de voto das pesquisas servem como álibi para: omitir os candidatos "mal colocados", reforçando esquemas mentais que limitam a escolha do eleitor a duas ou três alternativas; omitir a ocorrência de outros pleitos majoritários e proporcionais, que são objeto de um número menor de pesquisas de intenção de voto; pregar o "voto útil", ou voto estratégico, em favor de determinado candidato; atribuir ao eleitorado anseios cuja existência os números, por si só, não permitiriam inferir (no caso das eleições aqui estudadas, um difuso "anseio de mudança"). Muitas das conclusões a que chegam os analistas, porém, não poderiam ser extraídas dos números das pesquisas, a começar pelo fato de que as perguntas formuladas aos entrevistados carecem de aprofundamento que propicie elementos de interpretação. As análises, além disso, raramente levam em conta a possibilidade de erros metodológicos ou de interpretação, ou de fraude pura e simples nesses números, suscetíveis de invalidar completamente esses levantamentos como instrumento de análise. Apontamos algumas dessas questões metodológicas na seção 1.2. Uma maior transparência por parte das empresas de pesquisas, "abrindo" os dados brutos em que baseiam seus números finais, seria desejável numa sociedade democrática, por permitir questionamentos que possam conduzir a uma compreensão maior, por parte do cidadão, em relação àquilo que as pesquisas são capazes ou não de realmente dizer sobre as tendências do eleitorado.

Porém, mesmo que prevalecesse a mais absoluta transparência em relação às pesquisas durante as campanhas presidenciais brasileira de 2014 e argentina de 2015, é possível que isso não tivesse impacto relevante sobre o conteúdo da cobertura dos meios de comunicação de massa dos dois países. Como mostrado neste trabalho, uma das características dos enquadramentos presentes nas análises dos colunistas políticos é a tendência a não lançar dúvida sobre a credibilidade das pesquisas, discutindo-lhes a metodologia, por exemplo. Isso ocorre porque o uso das pesquisas se insere numa lógica persuasiva que não exige um aprofundamento da interpretação dos números; pelo contrário, esse aprofundamento poderia ser nocivo à estratégia argumentativa que se deseja impor. Neste sentido, o trabalho dos colunistas se caracteriza por uma intencionalidade, em que a pesquisa dá suporte científico (ou pseudocientífico, se questionarmos sua cientificidade) a um projeto ideológico. 
Em um ambiente de grande concentração da propriedade dos meios de comunicação - em que pese tentativas de enfrentar a questão, como a Ley de Medios argentina -, o debate em torno do uso das pesquisas ganha ainda mais relevância, pelo risco de prevalência de enquadramentos hegemônicos. Embora esta pesquisa, por seu recorte, se limite à análise de grandes veículos, temos motivos para crer que os enquadramentos aqui apresentados praticamente não foram contestados por contraenquadramentos que permitissem ao eleitor individual chegar a conclusões diferentes daquelas apresentadas pelos colunistas. Essas conclusões, por sua vez, refletem em grande medida a linha editorial dos veículos a que esses colunistas pertencem, não sendo outra a razão pela qual eles gozam de grande destaque nesses mesmos veículos, chegando em alguns casos a ocupar postos-chave de direção. Caracterizando-se esses meios de comunicação por uma "cobertura adversária" (GUAZINA, 2011), tanto em relação ao governo de Dilma Rousseff no Brasil quanto ao de Cristina Fernández de Kirchner na Argentina, era de esperar que seus enquadramentos espelhassem tal orientação política.

Embora aqui tenham sido apontados problemas relativos às pesquisas eleitorais, tanto em sua realização quanto em seu uso pelos meios de comunicação, esta dissertação não se propõe a recomendar práticas ou modelos alternativos. Porém, as evidências aqui apresentadas de sua utilização no agendamento e no enquadramento da cobertura das campanhas apontam para a necessidade de aprofundamento da discussão, tanto no âmbito do campo da comunicação quanto fora dele, para uma tomada de consciência em relação àquilo que as pesquisas realmente podem dizer a respeito do comportamento do eleitorado e aos riscos de manipulação que elas embutem. Também aí, apesar do debate recente sobre essa questão, trata-se de discussão antiga, cuja persistência indica que não se chegou ainda a uma solução satisfatória em relação ao emprego das pesquisas. Pode ser que nunca se chegue a essa solução - o que não torna o debate menos necessário a nosso ver, ao contrário.

À guisa de conclusão, recorremos mais uma vez à clarividência de Bourdieu, que em 1986, numa entrevista radiofônica sobre a febre de pesquisas que já então tomava conta dos meios de comunicação franceses, disse crer "que há um abuso da ciência", e que, "por essa razão, desejaria fortemente que instituições eficazes, controles eficazes sejam implantados e, em todo caso, a desconfiança se generalize em relação às 
pesquisas: que os políticos, os jornalistas etc., enxerguem de maneira desconfiada - isto é, com vigilância - as pesquisas” (BOURDIEU, apud SNÉGAROFF, 2017). 


\section{Referências}

A CPI das Pesquisas. Folha de S. Paulo, 9 nov. 1998, p. A-2.

COMPARECIMENTO em massa, com uma abstenção quase nula. Diário da Noite, 27 mar. 1945, p. 1-2.

CONSEJO Nacional Electoral abre investigación a firmas encuestadoras. El Espectador, 6 out. 2015. Disponível em http://www.elespectador.com/ noticias/politica/consejo-nacional-electoral-abre-investigacion-firmas-en-articulo591132.

CPI da ignorância. Folha de S. Paulo, 18 fev. 2015, p. A-2.

MÁRCIA Cavallari: pesquisa não é infalível. Congresso em Foco. < http://congressoemfoco.uol.com.br/noticias/marcia-cavallari-\%E2\%80\%9Cpesquisanao-e-infalivel\%E2\%80\%9D/>. Disponível em 14 out. 2012.

MUDANÇA de última hora no eleitorado. $O$ Globo, 8 nov. 1948, p. 9.

PESQUISAS eleitorais. Site do Ibope. <http://www.ibope.com/pt$\mathrm{br} /$ conhecimento/historicopesquisaeleitoral/Paginas/default.aspx?start1=281>.

POLÉMICA por la regulación de las encuestas electorales. Clarín, <http://www.clarin.com/politica/encuestas_electorales_0_1404459631.html>.

Disponível em 1 ago. 2015.

SONDAGES: 'Le Parisien' fait une pause. Le Monde, 5 jan. 2017, caderno Médias \& Pixels, p. 8.

VAI falar o Sr. Auricélio. Diário Carioca, 26 abr. 1949, p. 7.

ABREU, Alzira A.; DE PAULA, Christiane J. Dicionário Histórico-Biográfico da Propaganda no Brasil. Rio de Janeiro: FGV/ABP, 2007.

ALBUQUERQUE, Afonso. "O paralelismo político em questão". Revista Compolítica, v. 2, n. 1, jan-jun. 2012, p. 5-28.

ALDÉ, Alessandra. A Construção da Politica - Democracia, Cidadania e Meios de Comunicação de Massa. Rio de Janeiro: FGV, 2004.

ALONSO, Belén. "Encuestas, Entre el Tecnicismo y la Política: una Aproximación a su Regulación en Argentina”. In: La Política en un Mundo Incierto: Representación, Gobernabilidad Democrática e Inclusión Social. CD-ROM. Rosário: Sociedad Argentina de Análisis Político, nov. 2004.

ANASTACIA, Fátima; RANULFO, Carlos, SANTOS, Fabiano. Governabilidade e Representação Política na América do Sul. Rio de Janeiro: Fundação Konrad Adenauer, 2004. 
ANDERSEN, Asger L.; JENSEN, Thomas. "Exit polls and voter turnout". Journal of Theoretical Politics, v. 26, n. 1, p. 117-34.

ASSOCIAÇÃO NACIONAL DE JORNAIS. "Maiores jornais do Brasil”. Disponível em <http://www.anj.org.br/maiores-jornais-do-brasil/>. Acesso em 25 jan. 2017.

ATKIN, Charles K.; GAUDINO, James. "The Impact of Polling on the Mass Media". The Annals of the American Academy of Political and Social Science, v. 472, mar. 1984, p. 119-28.

BACQUÉ, Raphaëlle; SAVEROT, Denis. Chirac président: les coulisses d'une victoire. Paris: Editions du Rocher, 1995.

BARBOSA, Haroldo. “Coisas que incomodam”. Diário da Noite, 28 dez. 1949, p. 4.

BATESON, Gregory. "A Theory of Play and Fantasy". In: SALEN, Katie; ZIMMERMANN, Eric (Orgs.). The Game Design Reader - A Rules of Play Anthology. Cambridge: The MIT Press, 2006, p. 314-28.

BAUDRILLARD, Jean. "Le politique et la simulation". Le Monde Diplomatique, mai. 1978 , p. 28.

BERELSON, Bernard R.; LAZARSFELD, Paul F.; McPHEE, William N. Voting: A study of opinion formation in a presidential campaign. Chicago: The University of Chicago Press, 1954.

BERGER, Peter; LUCKMANN, Thomas. The Social Construction of Reality. $11^{\mathrm{a}}$ ed. Londres: Penguin, 1991.

BIBLIOTECA DEL CONGRESO NACIONAL DE CHILE. "Encuestas electorales. Experiencia comparada”. BCN Informe, 14 nov. 2012.

BIROLI, Flávia. “Autonomia, preferências e assimetria de recursos". Revista Brasileira de Ciências Sociais, v. 31, n. 90, fev. 2016, p. 39-56.

BIROLI, Flávia; MIGUEL, Luís Felipe; MOTA, Fernanda F. "Mídia, eleições e pesquisas de opinião no Brasil (1989-2010): um mapeamento da presença das pesquisas na cobertura eleitoral". In: Revista Compolítica, v. 1, n. 1, mar.-abr. 2011, p. 68-89.

BLOCH, Arnaldo. "Palavra de jornalista”. O Globo, 1 jun. 2003, Segundo Caderno, p. 1.

BOURDIEU, Pierre. "O Campo Científico". In: ORTIZ, Renato (Org.). Pierre Bourdieu: Sociologia. São Paulo: Ática, 1983, p. 123-155. 1292-309.

. “L'opinion publique n'existe pas”. In: Les Temps Modernes, n. 318, jan. 1973, p. _. "Political, Social Science, and Journalistic Field". In: BENSON, R.; NEVEU, E. Bourdieu and the Journalistic Field. Cambridge: Polity Press, 2005. 
. "Sur le Pouvoir Symbolique”. In: Annales. Économies, Sociétés, Civilisations, ano 32 , n. 3, 1977, p. 405-11.

BOUZA, Fermín. "Comunicación Política: Encuestas, Agendas y Procesos Cognitivos Electorales”. In: Praxis Sociológica, n. 3, 1998, p. 49-58.

CACCIATORE, Michael A.; SCHEUFELE, Dietram A.; IYENGAR, Shanto. "The End of Framing as We Know It... And The Future of Media Effects". Mass Communication and Society, ago. 2015.

CANTANHÊDE, Eliane. “A derrota de Dilma”. Folha de S. Paulo, 31 ago. 2014, p. A2.

CARRATO, Angela. "Imprensa mineira, um monopólio próximo do fim”. In: MOUILLAUD, Mauricio; PORTO, Sérgio D. (Orgs.). O Jornal: da forma ao sentido. Brasília: UnB, 2002.

CARVALHO, José Ferreira; FERRAZ, Cristiano. "A Falsidade das Margens de Erro de Pesquisas Eleitorais Baseadas em Amostragem por Quotas". Trabalho acadêmico da Universidade Federal de Santa Catarina, c. 2006. Disponível em www.egov.ufsc.br/portal/sites/default/files/anexos/32729-40324-1-PB.pdf.

CARVALHO, Luiz Maklouf. João Santana: um marqueteiro no poder. Rio de Janeiro: Record, 2015.

CLYMER, Adam. "The man who made polling what it is". The New Tork Times, 28 jul. 1984.

COELHO, Marcelo. “Como eles decidiram”. Folha de S. Paulo, 5 out. 2014, p. ES10.

COHN, Nate. "Polling's Secrecy Problem". The New York Times, 28 mai. 2015, p. A3.

CORVAGLIA, Julián. "La cobertura de los períodos de campaña electoral en la prensa gráfica argentina. Los casos de Clarín y La Nación en 1989 y 2003”. Tese de doutorado da Facultad Latinoamericana de Ciencias Sociales, 2009. Disponível em <http://repositorio.flacsoandes.edu.ec/xmlui/bitstream/handle/10469/2616/Tesis_Julian_ Ernesto_Corvaglia_Aguilar.pdf;jsessionid=E3BC6D653B674B26DBCF87651CCBCFB 4 ? sequence $=1>$.

CRETTAZ, José. "Argentina Debate tuvo más audiencia que la final del mundial de Brasil 2014”. Sítio do jornal La Nación. <http://www.lanacion.com.ar/1846009>. Disponível em 16 nov. 2014.

D’ANGELO, Paul; KUYPERS, Jim A. (Orgs.) Doing News Framing Analysis: Empirical and Theoretical Perspectives. Nova York: Routledge, 2010.

DATAFOLHA. "Na urna eletrônica, 51\% acertam número de candidato à Presidência". <datafolha.folha.uol.com.br/eleicoes/2014/10/1525353-na-urna-eletronica-51-acertamnumero-de-candidato-a-presidencia.shtml>. Disponível em 1 out. 2014. Acesso em 20 dez. 2016. 
DE ANGELIS, Carlos F. (Org.). Radiografía del voto porteño. Buenos Aires: Atuel, 2009.

"Dilma tem 37\%, Aécio 20\% e Campos 11\%, informa Datafolha." Valor Econômico. < http://www.valor.com.br/politica/3542180/dilma-tem-37-aecio-20-e-campos-11informa-datafolha>. Disponível em 9 mai. 2014.

DOMINGOS, Anselmo. “O Ibope está aí”. Diário da Noite, $1^{\circ}$ jul. 1944, p. 5.

DUARTE, Cíntia Barbosa. "As mudanças jurídicas das pesquisas eleitorais no Brasil." Revista do Tribunal Regional do Pará, v.1, n. 2, set./dez. 2009, p. 16-23.

DUARTE, Guilherme et alii. "Estatísticos denunciam fraudes em pesquisas". O Estado de S. Paulo, 21 out. 2016, p. A8.

DUVERGER, Maurice. "Factors in a Two-Party and Multiparty System". In: Party Politics and Pressure Groups. Nova York: Thomas Y. Crowell, 1972, p. 23-32.

ENTMAN, Robert. "Framing: Toward Clarification of a Fractured Paradigm". Journal of Communication, v. 43, n. 4, outono de 1993.

. "Framing U.S. Coverage of International News: Contrasts in Narratives of the KAL and Iran Air Incidents". Journal of Communication, v. 41, n. 4, outono de 1991.

ENTMAN__. Projections of Power: Framing News, Public Opinion, and U.S. Foreign Policy. Chicago: The University of Chicago Press, 2004.

FEASBY, Colin C. J. "Public Opinion Poll Restrictions, Elections, and the Charter". University of Toronto Faculty Law Review, v. 55, n. 2, primavera 1997.

FIORINA, Morris P. "The voting decision: instrumental and expressive aspects". The Journal of Politics, v. 38, n. 2, 1976, p. 390-413.

FONTENELLE, André. "França dividida escolhe presidente". Folha de S. Paulo, 6 mai. 1995, p. 2-10.

24.

. "Socialistas preparam era pós-Mitterrand". Folha de S. Paulo, 16 abr. 1995, p. 1-

FOURNIER, Patrick. "Time-of-voting decision and susceptibility to campaign effects". Electoral Studies, v. 23, n. 4, dez. 2004, p. 661-81.

GOFFMAN, Erving. Frame Analysis - An Essay on the Organization of Experience. Northeastern University Press, Boston, 1986.

GRAMACHO, Wladimir G. "Surveys pré-eleitorais nas eleições brasileiras de 2014: erros, acertos e polêmicas". Revista de Estudos Brasileiros, v. 2, n. 2, $1^{\text {o }}$ sem. 2015, p. 115-31. 
GUAZINA, Liziane S. Jornalismo em Busca de Credibilidade: A Cobertura Adversária do Jornal Nacional no Escândalo do Mensalão. Tese de doutorado. Brasília: UnB, 2011.

HABERMAS, Jürgen. "Technology and Science as 'Ideology”". In: SEIDMAN, Steve (Org.).Jürgen Habermas on Society and Politics: A Reader. Boston: Beacon Press, 1989, p. 237-65.

HALlin, Daniel C.; MANCINI, Paolo. Comparing Media Systems: Three Models of Media and Politics. Cambridge, Reino Unido: Cambridge University Press, 2004.

(Orgs.). Comparing Media System Beyond the Western World. Cambridge, Reino Unido: Cambridge University Press, 2011.

IBOPE. <http://www.ibope.com/pt-br/conhecimento/historicopesquisaeleitoral/Paginas/ default.aspx?start1=281>. Disponível em 21 out. 2015.

INSTITUTO FEDERAL ELECTORAL. Estudios Electorales en Perspectiva Internacional Comparada: Regulación de las Campañas Electorales en 18 Países de América Latina. Cidade do México: IFE, 2013.

INSTITUTO VERIFICADOR DE CIRCULACIONES. El boletín 2016. Disponível em <http://www.revistaairelibre.com.ar/boletin.ivc.pdf >. Acesso em 25 jan. 2017.

IYENGAR, Shanto. "Speaking of Values: The Framing of American Politics". The Forum, v. 3, n. 3, 2005. Disponível em http://www.bepress.com/forum.

KAIREPOVS, Dainis. Luta Subterrânea: o PCB em 1937-38. São Paulo: Unesp, 2003.

KISH, Leslie. Survey Sampling. Nova York: John Wiley and Sons, 1965.

KOVACH, Bill; ROSENSTIEL, Tom. Os elementos do Jornalismo: O que os Jornalistas Devem Saber e o Público Exigir. São Paulo: Geração Editorial, 2003.

KRAMER, Dora. "Despedida". O Estado de S. Paulo. <http:// politica.estadao.com.br/blogs/dora-kramer/despedida/>. Disponível em 12 dez. 2016.

KUHN, Thomas S. The Structure of Scientific Revolutions, v. II, n. 2. Chicago: The University of Chicago Press, 1970 [1962].

LAVAREDA, José Antônio. A democracia nas urnas: o Processo Partidário-Eleitoral Brasileiro (1945-1964). Rio de Janeiro: Iuperj, 1999.

LEVY, Bernard-Henri. "Qu'est-ce que le populisme? (À suivre)”. Le Point, 25 nov. 2016.

LIMA, Venício A. Mídia: crise política e poder no Brasil. São Paulo: Fundação Perseu Abramo, 2006.

LIMA, Venicio A.; GUAZINA, Liziane. "Jornal Nacional: A Política Simulada. Uma Análise Comparada com o Jornal da Record (março-agosto 1998)". In: LIMA, Venicio 
A. Mídia: Teoria e Política. São Paulo: Fundação Perseu Abramo, 2a ed., 2004, p. 269339.

LINZER, Drew. "Pollsters May Be Herding". Votamatic, 5 nov. 2012. Disponível em <http://votamatic.org/pollsters-may-be-herding/>. Acesso em 25 jan. 2017.

LIOTTI, Jorge. "The Complex Relationship Between the Media and the Political System in Argentina: From Co-option to Polarization". In: GUERRERO, Manuel A.; MÁRQUEZ-RAMÍREZ, Mireya. Media Systems and Communication Policies in Latin America. Basingstoke: Palgrave Macmillan, 2014.

LIPPMANN, Walter. Public Opinion. Mineola, NY: Dover, 2004 [edição original, Nova York: Harcourt, Brace and Company, 1922].

LÓPEZ, Miguel Ángel et alii. "Experiencia Internacional en Regulación y Autorregulación de Encuestas Políticas y Electorales de Opinión Pública. Lecciones para Chile”. In: Calidad de la Democracia, Transparencia e Instituciones Públicas. Santiago: El Ministerio, 2009, pp 223-58.

McCOMBS, Maxwell. A Teoria da Agenda: A Mídia e a Opinião Pública. Petrópolis: Vozes, 2009.

McCOMBS, Maxwell; GHANEM, Salma. "The convergence of agenda setting and framing”. In: REESE, Stephen; GANDY Jr., Oscar; GRANT, August. Framing Public Life: Perspectives on Media and our Understanding of the Social World. Mahwah, NJ: Lawrence Erlbaum Associates, 2001, p.67-81.

McCOMBS, Maxwell; SHAW, Donald L.; WEAVER, David (Orgs.). Communication and Democracy: Exploring the Intellectual Frontiers in Agenda-Setting Theory. Mahwah, Nova Jersey: Lawrence Erlbaum Associates, 1997.

McCOMBS, Maxwell; SHAW, Donald. "The Agenda-Setting Function of Mass Media”. Public Opinion Quarterly, v. 36, n. 2, 1972, p. 176-87.

MIGUEL, Luís Felipe; BIROLI, Flávia. "Visibilidade na mídia e campo político no Brasil". Dados, v. 53, n. 3, 2010. Disponível em < http://dx.doi.org/10.1590/S001152582010000300006>.

MOCCI, Jean-Philippe. "La grande mutation des sociétés françaises de sondages". Le Figaro, 23 oct. 2000.

MÖNCKENBERG, Maria Olivia. Los Magnates de la Prensa: Concentración de los medios de comunicación en Chile. Santiago: Debate, 2011.

MORDECKI, Daniel. "En boca-de-urna no entran moscas". Disponível em http://www.montevideo.com.uy/auc.aspx?250507. 
MOTA, Johane. "João Santana sobre eleição: 'O que se quer é continuidade com mudança'." <http://www.vermelho.org.br/noticia_print.php?id_noticia=242793\&id_ secao=1>. Disponível em 24 mai. 2014.

NEWPORT, Frank. Polling Matters: Why Leaders Must Listen to the Wisdom of the People. Nova York: Hachette, 2004.

OROZCO TASCÓN, Cecilia. “"La autorregulación no ha logrado su propósito"”. El Espectador, 10 out. 2015. Disponível em http://www.elespectador.com /noticias/politica/autorregulacion-no-ha-logrado-su-proposito-articulo-591982.

PETERS, John D.; SIMONSON, Peter. Mass Communication and American Social Thought: Key Texts, 1919-1968. Lanham, Maryland: Rowman \& Littlefield, 2004.

POPPER, Karl R. Conjecturas e Refutações (O Progresso do Conhecimento Científico). Brasília: UnB, 1980.

“Porre é soprar o danado do bafômetro". Extra, 19 abr. 2011, p. 1.

PORTO, Mauro. "Enquadramentos da Mídia e Política". In: RUBIM, Antônio A. C. (Org.). Comunicação e Política: Conceitos e Abordagens. Salvador: Edufba, 2004.

. "The Principle of Diversity in Journalism". Brazilian Journalism Research, v. 1, n. $1,1^{0}$ sem. 2005 , p. $135-53$.

REESE, Stephen; GANDY, Oscar; GRANT, August (Orgs.). Framing Public Life: Perspectives on Media and our Understanding of the Social World. Mahwah, Nova Jersey, 2001.

RODRIGO ALSINA, Miquel. A Construção da Notícia. Petrópolis: Vozes, 2009.

RODRIGUES, Fernando. “Polarizou”. Folha de S. Paulo, 30 ago. 2014, p. A2.

ROSSI, Clóvis. “O fato novo?”. Folha de S. Paulo, 26 abr. 1989, p.A2.

SANTOS, Ana Cristina; PAULINO, Fernando O. "Políticas de comunicação na Argentina: como a atuação da Coalização por uma Radiodifusão Democrática e os cinco anos de vigência da Ley de Medios podem ser úteis ao Brasil”. Artigo apresentado ao V Colóquio Brasil-Argentina de Ciências da Comunicação, Rio de Janeiro, set. 2015.

SCHEUFELE, Dietram; TEWKSBURY, David. "Framing, Agenda Setting, and Priming: The Evolution of Three Media Effects Models". Journal of Communication, v. 57, 2007, p. 9-20.

SCHWARTSMAN, Helio. “Sinais e ruídos". Folha de S. Paulo, 7 out. 2014, p. A2.

SEMPRINI, Andrea. Le Multiculturalisme. Coleção Que Sais-Je. Paris: Presses Universitaires de France, 1997. 
SHACKMAN, Gene. "Sample size and design effect". Paper apresentado na sucursal de Albany da American Statistical Association, 24 mar. 2001. < http://faculty.smu.edu/slstokes/stat6380/deff\%20doc.pdf>. Acessado em 26 out. 2016.

SILVER, Nate. The signal and the noise - The art and science of prediction. Londres: Penguin, 2012.

SIMON, Herbert A. "Bandwagon and Underdog Effects and the Possibility of Election Predictions". Public Opinion Quarterly, v. 18, n. 3, 1954, p. 245-53.

SNÉGAROFF, Pierre. "Pierre Bourdieu sur les sondages : 'Je souhaite que la suspicion se généralise'”. Histoires d'Info, Rádio France Info, 4 jan. 2017.

SOUZA, Josias. "Principal cabo eleitoral de Marina é o saco cheio". Blog do Josias, UOL, 31 ago. 2014.

SPAYD, Liz. "Want to Know What America's Thinking? Try Asking". The New York Times, 9 nov. 2016. Disponível em < http://nyti.ms/2eDznMK>.

STRÖMBACK, Jesper. "The Media and Their Use of Opinion Polls: Reflecting and Shaping Public Opinion". In: HOLTZ-BACHA, Christina; STRÖMBACK, Jesper (Orgs.). Opinion Polls and the Media: Reflecting and Shaping Public Opinion. Londres: Palgrave MacMillan, 2012, p. 1-22.

TAKESHITA, Toshio. "Exploring the Medial Roles in Defining Reality: From IssueAgenda Setting to Attribute Agenda-Setting". In: McCOMBS, Maxwell; SHAW, Donald L.; WEAVER, David (Orgs.). Communication and Democracy: Exploring the Intellectual Frontiers in Agenda-Setting Theory. Mahwah, Nova Jersey: Lawrence Erlbaum Associates, 1997, p. 15-27.

TAYLOR, Curtis R.; YILDIRIM, Huseyin. "Public Information and Electoral Bias". Games and Economic Behavior, n. 68, 2010, p. 353-75.

TETLOCK, Philip; GARDNER, Dan. Superforecasting: The Art and Science of Prediction. Nova York: Crown, 2015.

THIOLLENT, Michel. Pesquisas Eleitorais em Debate na Imprensa. São Paulo: Cortez, 1989.

TRAUGOTT, Michael W.; LAVRAKAS, Paul J. The Voter's Guide to Election Polls. Lanham, Maryland: Rowman \& Littlefield, 2008.

TREJO DELARBRE, Raúl. "Muchos medios en pocas manos: concentración televisiva y democracia en América Latina". Intercom - Revista Brasileira de Ciências da Comunicação, v. 33, n. 1, jan.-jun. 2010, p. 17-51.

TRIBUNAL SUPERIOR ELEITORAL. Informações e Dados Estatísticos sobre as Eleições 2014. Brasília: TSE, 2014. 
VOMMARO, Gabriel. "Lo que quiere la gente”: los sondeos de opinión y el espacio de la comunicación política en Argentina (1983-1999). Universidad Nacional de General Sarmiento. Buenos Aires: Prometeo, 2008.

WALDEN, Graham R. Polling and Survey Research Methods, 1935-1979: An Annotated Bibliography. Westport, Connecticut: Greenwood, 1996.

WOLF, Mauro. Teorias da Comunicação. Lisboa: Presença, 1999.

\section{Programas de televisão}

Canal Livre, TV Bandeirantes, 27 set. 2014.

Roda Viva, TV Cultura, 6 out. 2014.

Artigos de Dora Kramer em $O$ Estado de S. Paulo; Merval Pereira em O Globo; Eduardo van der Kooy em Clarín; e Joaquín Morales Solá em La Nación, nos períodos pesquisados

\section{Dora Kramer}

Todos os textos abaixo foram publicados em O Estado de S. Paulo e no blog da autora no sítio do jornal na internet (http://politica.estadao.com.br/blogs/dora-kramer/).

“A sangue quente", 15 ago. 2014, p. a6 "Presença de Marina", 17 ago. 2014, p. a6

"Páreo duro", 19 ago. 2014, p. a6

"Falsa magra", 20 ago. 2014, p. a6

"Mercado de ilusões", 21 ago. 2014, p. a6

"Fio terra", 22 ago. 2014, p. a6

"Desnorteados", 24 ago. 2014, p. a6

"O recomeço", 26 ago. 2014, p. a6

"Sustentar é preciso", 27 ago. 2014, p. a8

"Satisfação garantida", 28 ago. 2014, p. a6

"O diabo a quatro", 29 ago. 2014, p. a6

"Vestida para enfrentar", 31 ago. 2014, p. a6

“Abalar o andor", 2 set. 2014, p. a8

"Telhado de vidro", 3 set. 2014, p. a8

"Motor acelerado", 4 set. 2014, p. a6

"Alívio relativo", 5 set. 2014, p. a6

"Cai o pano", 7 set. 2014, p. a6

“Sob nova direção", 9 set. 2014, p. a8

"Atos falhos", 10 set. 2014, p. a6

“Desfaçatez ilimitada", 11 set. 2014, p. a6 
"Iludir é preciso", 12 set. 2014, p. a6

"Acender as velas", 14 set. 2014, p. a6

"Demolição de valores", 17 set. 2014, p. a6

"Munição avariada", 18 set. 2014, p. a8

“Gato por lebre", 19 set. 2014, p. a6

"Reverso da fortuna", 21 set. 2014, p. a6

“A falta que opinião faz", 23 set. 2014, p. a6

"O tempo ruge", 24 set. 2014, p. a6

"Na mão da apatia", 25 set. 2014, p. a6

“Zero noção de Estado", 26 set. 2014, p. a6

"Caso de política", 28 set. 2014, p. a6

"Perdas inegáveis", 30 set. 2014, p. a6

"Outro nível é possível”, 1 out. 2014, p. a6

"Momento de indecisão", 2 out. 2014, p. a6

"Rédeas soltas", 3 out. 2014, p. a8

"Dois na gangorra", 5 out. 2014, p. h11

"Nunca antes" ${ }^{82}, 6$ out. 2014, p. h12

"Mano a mano pesado", 7 out. 2014, p. h9

“Com os pés no chão", 8 out. 2014, p. a6

"Caixinha de surpresas", 9 out. 2014, p. a6

"A estrela desce", 10 out. 2014, p. a6

"Civilizar é preciso", 12 out. 2014, p. a6

"Zona de conforto", 14 out. 2014, p. a6

"Na bacia das almas", 15 out. 2014, p. a8

“Ação entre inimigos", 16 out. 2014, p. a6

“Cenário enigmático", 17 out. 2014, p. a6

"A volta do cipó", 19 out. 2014, p. a6

"Leite derramado", 21 out. 2014, p. a6

"O herói sem caráter", 22 out. 2014, p. a6

“De oito a 80", 23 out. 2014, p. a6

“Tudo junto e desregrado", 24 out. 2014, p. a6

"Foi ruim, mas foi bom", 26 out. 2014, p. h15

\section{Merval Pereira}

Todos os textos abaixo foram publicados em $O$ Globo e no blog do autor no sítio do jornal na internet (http://blogs.oglobo.globo.com/merval-pereira/).

"Presidência é destino", 14 ago. 2014, p. 4

"Por baixo dos panos", 15 ago. 2014, p. 4

"O novo grid", 17 ago. 2014, p. 4

"Foi dada a largada", 19 ago. 2014, p. 4

${ }^{82}$ Publicado com outro título ("O desmonte do previsível”) na edição "nacional” do jornal, ou seja, a que circula fora de São Paulo. 
"Voto útil", 20 ago. 2014, p. 4

"Rede na cabeça", 21 ago. 2014, p. 4

"Polarizações", 22 ago. 2014, p. 4

“Não vai ter eleição?”, 23 ago. 2014, p. 4

"O papel dos partidos", 24 ago. 2014, p. 4

"Revendo conceitos", 26 ago. 2014, p. 4

“A outra eleição", 27 ago. 2014, p. 4

"Mudança de tom", 28 ago. 2014, p. 4

"Contradições", 29 ago. 2014, p. 4

"A onda se forma", 30 ago. 2014, p. 4

"A utilidade do voto", 31 ago. 2014, p. 4

"Nova polarização", 2 set. 2014, p. 4

"Vale tudo", 3 set. 2014, p. 4

"A resiliência de Dilma", 4 set. 2014, p. 4

"Polarizações regionais", 5 set. 2014, p. 4

"Velha política em xeque", 6 set. 2014, p. 4

"O fato novo", 7 set. 2014, p. 4

"Delenda Marina", 9 set. 2014, p. 4

"Palpos de aranha", 10 set. 2014, p. 4

"Disputa acirrada", 11 set. 2014, p. 4

"Dificuldades da nova política", 12 set. 2014, p. 4

"Convicções", 13 set. 2014, p. 4

"O medo como método", 14 set. 2014, p. 4

"A mais difícil", 16 set. 2014, p. 4

"Rodada ruim para Dilma", 17 set. 2014, p. 4

"De volta ao jogo", 18 set. 2014, p. 4

"A vaca e o brejo", 19 set. 2014, p. 4

"Os caminhos do voto", 20 set. 2014, p. 4

"Uma eleição diferente", 21 set. 2014, p. 4

"Isto é que é errata", 23 set. 2014, p. 4

"Marina resiste; Dilma cresce", 24 set. 2014, p. 4

"Uso indevido", 25 set. 2014, p. 4

"A força da cidadania", 26 set. 2014, p. 4

“Todos atrás do voto útil", 27 set. 2014, p. 4

"De cabeça para baixo", 28 set. 2014, p. 4

“Quem é o antipetista?", 30 set. 2014, p. 4

"Cabeça a cabeça", 1 out. 2014, p. 4

"Unidade (re)forçada", 2 out. 2014, p. 4

"Detalhes eleitorais", 3 out. 2014, p. 4

"Sem medo do PT", 4 out. 2014, p. 4

“Atropelada na reta final", 5 out. 2014, p. 4

“A política nos números", 6 out. 2014, p. 4

"PE e SP derrubam PT", 8 out. 2014, p. 4

“A disputa no Rio", 9 out. 2014, p. 4 
"Virada", 10 out. 2014, p. 4

"Acordo programático", 11 out. 2014, p. 4

"Caminho aberto", 12 out. 2014, p. 4

"O calendário político", 14 out. 2014, p. 4

"Votos cristalizados", 15 out. 2014, p. 4

"Nos detalhes", 16 out. 2014, p. 4

"Abaixo da cintura", 17 out. 2014, p. 4

"Vitimização de Dilma", 18 out. 2014, p. 4

“João", 19 out. 2014, p. 4

"Voto a voto", 21 out. 2014, p. 4

"Margem de erro", 22 out. 2014, p. 4

"Menor do que entrou", 23 out. 2014, p. 4

“Tendências e denúncias", 24 out. 2014, p. 4

"Confronto inédito", 25 out. 2014, p. 4

“A boca está fechando", 26 out. 2014, p. 4

\section{Eduardo van der Kooy}

Todos os textos abaixo foram publicados em Clarín e na página de colunas do autor no sítio do jornal na internet (http://www.clarin.com/tema/eduardo_van_der_kooy.html).

"Scioli Macri: la guerra de los pompones", 19 ago. 2015, p. 8

"Entre Cristina y Scioli, algo no anda bien", 23 ago. 2015, p. 45

“Otro tropiezo en el camino de Scioli”, 26 ago. 2015, p. 6

"El país trucho que desnudó una elección", 30 ago. 2015, p. 45

"Scioli, Macri y Massa, en una meseta", 2 set. 2015, p. 8

"Las dudas de Scioli, la sombra de Nisman", 6 set. 2015, p. 45

"Scioli no sabe qué hacer con Cristina", 27 set. 2015, p. 45

"Las bombitas de Cristina en la campaña", 30 set. 2015, p. 8

"Los miedos de Cristina antes de partir", 4 out. 2015, p. 45

"El voto útil, la presa de Macri y Massa", 7 out. 2015, p. 13

"El mensaje del viejo espía para Cristina", 11 out. 2015, p. 45

“Candidatos y campaña, sin despegue”, 14 out. 2015, p. 12

"Para Cristina, lo primero es la 'famiglia",, 18 out. 2015, p. 45

"Cinco días antes, incertidumbre total", 21 out. 2015, p. 12

"Ante un futuro prendido con alfileres", 25 out. 2015, p. 45

"Más que una derrota fue un naufragio", 26 out. 2015, p. 9

"Ya hay fuego entre los K y el sciolismo", 27 out. 2015, p. 8

"El sciolismo y los K, del shock a la crisis", 28 out. 2015, p. 5

“Cómo la Presidenta abandona a Scioli”, 1 nov. 2015, p. 43

"La campaña de los K que ayuda a Macri”, 4 nov. 2015, p. 7

"El gran problema para Scioli es Cristina", 8 nov. 2015, p. 45

"La crisis ya irrumpe entre los barones", 11 nov. 2015, p. 6

"Las últimas guerras de Scioli con los K", 15 nov. 2015, p. 45 
"Una luz de ventaja de Macri sobre Scioli", 16 nov. 2015, p. 5

"Tiemblan las billeteras de Scioli y Macri”, 18 nov. 2015, p. 12

"En las vísperas, el repliegue kirchnerista", 22 nov. 2015, p.45

\section{Joaquín Morales Solá}

Todos os textos abaixo foram publicados em La Nación e na página de colunas do autor no sítio do jornal na internet (http://www.lanacion.com.ar/autor/joaquin-morales-sola$51)$.

"Tuiteros, la guerra inservible de Scioli", 19 ago. 2015, p. 5

"La crisis económica que dejará Cristina Kirchner", 23 ago. 2015, p. 31

"El peor final: violencia y sangre", 26 ago. 2015, p. 6

"Muchas y viejas trampas del sistema electoral", 30 ago. 2015, p. 27

"En dos semanas, Scioli perdió su paraíso político", 2 set. 2015, p. 11

"Scioli y Macri, hacia un cambio económico clave", 6 set. 2015, p. 31

"Las sospechas de Tucumán se extienden a todo el país", 9 set. 2015, p. 6

“¿Y si Zamora es presidente?”, 13 set. 2015, p. 25

"Una afilada ironía en la despedida", 16 set. 2015, p. 8

"Una decisión demoledora", 17 set. 2015, p. 9

"El fracaso de la política en tiempos electorales", 20 set. 2015, p. 27

"Tucumán, un reto delicado para la Corte", 22 set. 2015, p. 8

“Todo se decidirá en los últimos días”, 11 out. 2015, p. 35

"Pendientes de un puñado de adhesiones", 14 out. 2015, p. 7

"La batalla final de los sobrevivientes", 18 out. 2015, p. 31

"Ansiosos frente a un electorado que no se decide", 21 out. 2015, p. 10

"El principio del fin para Cristina", 25 out. 2015, p. 33

"Una noche que cambió la política argentina", 26 out. 2015, p. 10

"El efecto de un dramático cambio social", 27 out. 2015, p. 8

"La continuidad, refugio y límite para Scioli”, 28 out. 2015, p. 6

"Una provocación antes de irse", 30 out. 2015, p. 13

"Dejar atrás al kirchnerismo", 1 nov. 2015, p. 31

"Un método que desdibuja los atributos de Scioli", 4 nov. 2015, p. 6

"La campaña de Cristina contra su candidato", 8 nov. 2015, p. 31

"La otra campaña del miedo, contra el candidato propio", 11 nov. 2015, p. 8

"La caída muestra el peor rostro del kirchnerismo", 15 nov. 2015, p. 33

"La conversión de Scioli", 17 nov. 2015, p. 10

"El laberinto donde se perdió Scioli", 20 nov. 2015, p. 9

“Adiós a una generación política", 22 nov. 2015, p. 33 
CRONOGRAMA

\begin{tabular}{|l|c|c|c|c|}
\hline Período/Atividade & $\begin{array}{c}1^{\mathbf{0}} \\
\text { sem. } \\
2015\end{array}$ & $\begin{array}{c}2^{\mathbf{0}} \\
\text { sem. } \\
2015\end{array}$ & $\begin{array}{c}1^{\mathbf{0}} \\
\text { sem. } \\
2016\end{array}$ & $\begin{array}{c}2^{\mathbf{0}} \\
\text { sem. } \\
2016\end{array}$ \\
\hline Elaboração do projeto & $\bullet$ & & & \\
\hline Disciplinas da pós-graduação & $\bullet$ & $\bullet$ & $\bullet$ & \\
\hline Pesquisa bibliográfica & $\bullet$ & $\bullet$ & $\bullet$ & \\
\hline Coleta dos dados & & $\bullet$ & $\bullet$ & \\
\hline Tabulação & & & $\bullet$ & \\
\hline Análise interpretativa & & & $\bullet$ & $\bullet$ \\
\hline Redação final da dissertação & & & & $\bullet$ \\
\hline
\end{tabular}


Apêndice I - Temas da agenda da campanha eleitoral no Brasil (2014) e na Argentina (2015), mencionados nas colunas analisadas

Temas mencionados nas colunas de Dora Kramer em $O$ Estado de S. Paulo (52 textos) e Merval Pereira em $O$ Globo (63 textos)

\section{Relacionados a Dilma Rousseff}

Ameaças à governabilidade - Sobre o risco de o governo não dispor de maioria no Congresso para governar, em caso de reeleição de Dilma.

Baixaria na campanha - O marqueteiro da campanha de Dilma, João Santana, foi acusado de adotar uma estratégia de campanha "suja", sobretudo por conta de um spot publicitário em que equiparava a proposta de autonomia do Banco Central, feita por Marina Silva, a "tirar a comida do prato" dos brasileiros mais pobres.

Capa de Veja: "Eles sabiam de tudo" - Título de capa da edição da revista Veja que chegou às bancas na antevéspera do segundo turno. Referia-se a um trecho do depoimento do doleiro Alberto Youssef, pivô da Operação Lava-Jato, em que este insinuava a possibilidade de Dilma Rousseff e Lula terem tido conhecimento prévio do esquema de propina na Petrobrás.

Controle social da mídia - A expressão designou as propostas de setores ligados ao governo para exercer algum tipo de influência sobre uma mídia percebida como oligopolizada, com medidas como educação para a leitura crítica da mídia; criação de um organismo oficial ou independente para analisar o conteúdo dos meios de comunicação; e medidas para redução da concentração da propriedade dos meios de comunicação, entre outras. Estas propostas encontraram, como era de esperar, forte resistência dos proprietários de grandes veículos de imprensa.

Criação de "conselhos populares" - Polêmica nascida em torno da proposta do governo de criar uma "Política Nacional de Participação Social” para debater políticas públicas. A ideia foi enquadrada pela oposição como uma tentativa de "bolivarização" do país, em analogia com o regime de esquerda implantado por Hugo Chávez na Venezuela.

Críticas aos ataques ao Estado Islâmico - Em 24 de setembro, em discurso nas Nações Unidas, a presidente afirmou que "o uso da força é incapaz de eliminar as causas profundas dos conflitos". Essa declaração foi interpretada por alguns colunistas como "defesa do diálogo" com os radicais islâmicos.

Desconstrução de Marina/Aécio - Estratégia de campanha negativa, por parte da campanha de Dilma em relação aos dois principais rivais, e ocasionalmente pela campanha de Aécio em relação a Marina.

"Dilmês" - Referência a lapsos linguísticos ou retóricos da presidente em manifestações públicas. 
Emprego fantasma de Igor Rousseff - Em debate na TV, Aécio Neves acusou o irmão da presidente de receber sem trabalhar na prefeitura de Belo Horizonte, na gestão de Patrus Ananias, do PT.

Erro nos dados do PNAD - Em 18 de setembro, o IBGE (Instituto Brasileiro de Geografia e Estatística) divulgou os dados anuais da PNAD (Pesquisa Nacional por Amostra de Domicílios). No dia seguinte o instituto retificou alguns dados, gerando críticas ao suposto "aparelhamento" do órgão pelo PT.

Fragilidade de Dilma - Em entrevista ao vivo após o debate de 16 de outubro, no SBT, a presidente sentiu-se mal, o que gerou especulações sobre sua saúde no auge da campanha.

Golpismo contra Dilma - Acusação, feita pelo PT contra a oposição, de buscar pela via judicial manobra visando à derrubada do governo.

Lula nos bastidores -Possíveis manobras do ex-presidente para influenciar o curso da campanha eleitoral.

Mensalão - Escândalo de compra de votos de parlamentares da base governistas, nascido em 2005 numa entrevista do deputado federal Roberto Jefferson à Folha de S. Paulo. Embora o escândalo já tivesse nove anos no momento da campanha de 2014, seus desdobramentos judiciais só cairiam em segundo plano à medida que a Operação Lava-Jato ganhava corpo.

Papel da militância do PT - Referência à imagem dos afiliados do partido como engajados e atuantes na campanha.

Perspectiva ruim da economia - Piora dos indicadores da economia em 2014 e as previsões pessimistas em relação à inflação, ao desemprego e ao déficit público para 2015.

Petrobrás/Operação Lava-Jato - Referências à investigação de corrupção, tornada pública em março de 2014, envolvendo diretores da estatal petrolífera. Partidos da base do governo (e, em alguns casos, da oposição) foram acusados de fazer parte de um esquema de propinas milionárias nos contratos da Petrobras.

Polarização pobres $\mathbf{x}$ ricos - Acusação feita aos responsáveis pela campanha de Dilma, entre o primeiro e o segundo turnos, de explorar um possível antagonismo entre o eleitorado da presidente, majoritário nas camadas mais pobres, e o de Aécio Neves, de perfil de renda mais elevado. Também se comentou uma suposta polarização Sudeste $\mathrm{x}$ Nordeste.

Possibilidade de fraude eleitoral - Dúvidas lançadas sobre a lisura do processo de votação via urna eletrônica, que impossibilita a recontagem dos votos pela ausência de registro individual do voto em papel. 
Possibilidade de impeachment - Referência a uma possível consequência dos desdobramentos da Operação Lava-Jato, após uma eventual reeleição.

Programas sociais - Referências ao Bolsa Família, ao Mais Médicos, ao Minha Casa Minha Vida e a outras ações do governo voltadas para a população de baixa renda.

Propaganda gratuita - Importância quantitativa do tempo de cada coligação no horário eleitoral de rádio e televisão. A legislação eleitoral, que atribui o tempo em proporção às bancadas das coligações, tende a favorecer os partidos do governo na alocação desse tempo.

Tática do medo - Similar à questão da baixaria na campanha, trata da acusação feita à campanha do PT de atribuir aos adversários a intenção de promover uma política econômica de austeridade, com corte de programas sociais e venda do patrimônio público.

Uso da máquina pública - Em algumas ocasiões durante a campanha a presidente foi acusada de tirar proveito do cargo para promoção eleitoral - por exemplo, convocando a imprensa para entrevistas na residência oficial, o Palácio da Alvorada.

Vandalismo contra a Editora Abril - Após a publicação da capa de Veja "Eles sabiam de tudo", um grupo de estudantes pichou a fachada da sede da editora que publica a revista.

Vitória de Fernando Pimentel em MG - Em Minas Gerais, estado natal de Aécio Neves (e da presidente), a eleição para o governo estadual ganhou caráter de microcosmo do pleito nacional, com a disputa entre Pimentel, candidato do PT e amigo da presidente, e Pimenta da Veiga, do partido de Aécio.

\section{Relacionados a Marina Silva}

Ameaças à governabilidade - Temor de que uma eventual vitória de Marina levasse a uma relação conflituosa com o Congresso, em razão da reduzida bancada parlamentar do PSB.

Apoio de Neca Setúbal/banqueiros - Integrante da bilionária família dona do banco Itaú, educadora e uma das principais conselheiras e doadoras de campanha de Marina, Neca Setúbal foi apontada como prova das contradições do discurso de Marina.

Avião da campanha de Campos - Dias após o desastre aéreo em que morreram Eduardo Campos e sua comitiva, surgiram suspeitas de irregularidades em relação à compra da aeronave, que teria contado com transferências bancárias para empresas fantasmas.

Comparação com Jânio e Collor - Candidatos "acima dos partidos" e com plataformas de "ética na política", Jânio Quadros e Fernando Collor foram eleitos pelo 
povo mas tiveram mandatos conturbados e interrompidos precocemente. A campanha do PT explorou o possível paralelismo entre os dois ex-presidentes e Marina.

Contradições da "nova política" - Marina se apresentou como uma candidata com novas práticas, mas seus detratores apontavam diversas incoerências nesse discurso, desde o fato de ter exercido vários cargos políticos até a aceitação de alianças com políticos e empresários, semelhantes às dos "velhos" políticos.

Dissidências no PSB - Marina enfrentou na campanha a má vontade e até a oposição aberta de dirigentes do partido, que enxergavam nela um "corpo estranho", alçada à condição de candidata em função de seu potencial eleitoral, e não de seu histórico no partido ao qual se filiara menos de um ano antes.

Eduardo Campos citado na Lava-Jato - O candidato do PSB foi citado pelo ex-diretor da Petrobras Paulo Roberto Costa, em delação premiada no âmbito da Operação Lava-Jato, como um dos políticos beneficiários do esquema de propina da Petrobrás. O vazamento desse depoimento ocorreu na revista Veja em 6 de setembro, dias depois da morte de Campos.

Fragilidade/choro de Marina - A candidata chorou em entrevista à Folha de S. Paulo, ao se referir ao rompimento com Lula, e sua saúde frágil era vista como possível óbice à sua campanha.

Independência do Banco Central - O programa de Marina defendia a autonomia do presidente do Banco Central (em relação ao Poder Executivo) no estabelecimento da política de juros. Seus adversários apontaram nisso uma concessão ao capital.

Inexperiência governamental - Acusação constantemente feita a Marina, cuja experiência administrativa limitava-se ao exercício do cargo de ministra do Meio Ambiente no governo Lula (2003-08).

Misticismo - A religiosidade da candidata (ordenada pastora da Assembleia de Deus em 2012) e sua história de superação da pobreza, do analfabetismo e dos problemas de saúde teriam influência sobre a parte do eleitorado mais suscetível a enxergar uma dimensão "mística" em sua trajetória.

Posição contra o casamento gay - Em agosto, a campanha de Marina retirou do programa de governo trecho que propunha a legalização do casamento gay. A mudança de posição teria desagradado a parte de seu eleitorado mais à esquerda.

Pré-Sal - Atribuição a Marina, defensora da preservação ambiental, da intenção de reduzir a produção de petróleo nas reservas da camada de pré-sal. A candidata teve que esclarecer sua posição, o que deu origem à acusação de contradizer-se. 
Programa "escrito a lápis" - Alterações no programa de governo, sobretudo a relativa ao casamento gay, ensejaram essa crítica, da parte da campanha de Aécio Neves: o documento programático de Marina estaria sujeito a constantes alterações.

Resistência do empresariado - $\mathrm{O}$ agronegócio seria reticente à chegada de Marina à presidência, em função de seu passado como defensora da preservação das florestas; a classe empresarial como um todo recearia seu triunfo na eleição devido a seu perfil historicamente ligado à esquerda.

Seringueiros contra Marina - A candidata do PSB começou na política à sombra de Chico Mendes, líder seringueiro de Xapuri (AC) assassinado em 1988. Porém, em agosto de 2014, uma líder dos seringueiros acusou a candidata de "abandonar" a categoria durante a campanha.

\section{Relacionados a Aécio Neves}

Aécio agressor de mulheres - Em 2009, quando era governador de Minas Gerais, Aécio foi acusado de agredir a namorada (e futura esposa) em uma festa no Rio de Janeiro.

Aeroporto de Cláudio - Aécio construiu, quando governador de Minas Gerais, um aeroporto em terras de sua família no município mineiro de Cláudio. O episódio foi manchete da Folha de S. Paulo em 20 de julho.

Andrea, irmã de Aécio - Em debate na TV, Dilma Rousseff acusou Aécio de nepotismo, por empregar a própria irmã no governo de Minas. O candidato do PSDB rebateu a acusação alegando que a irmã não recebeu remuneração.

Caso do bafômetro - Em 17 de abril de 2011 Aécio Neves foi parado em uma blitz de trânsito no Rio de Janeiro e não se submeteu ao teste do bafômetro.

Crise hídrica em São Paulo - O estado, governado por Geraldo Alckmin, do PSDB, viveu uma das maiores secas de sua história em 2014. Para os opositores, a demora em reconhecer a gravidade da situação poderia ser prejudicial à campanha do candidato do partido à presidência. Alckmin, porém, reelegeu-se governador ainda no primeiro turno, e Aécio venceu Dilma por ampla margem no estado, no segundo turno.

Derrota de Aécio em Minas Gerais - No estado onde nasceu e que já governou, esperava-se que o candidato do PSDB obtivesse uma votação superior à dos demais candidatos, tanto no primeiro quanto no segundo turno. $\mathrm{O}$ estado era visto como crucial para suas chances de eleger-se presidente.

Discordâncias internas no PSDB - Conflitos dentro do partido, sobretudo entre a ala comandada por José Serra e a que apoiava Aécio Neves, poderiam ser nocivos à campanha deste último. 
Fim do fator previdenciário - Regra introduzida em 1999, o fator é um índice multiplicador que reduz o valor das aposentadorias "precoces". Durante a campanha, Aécio chegou a defender sua abolição, mas depois voltou atrás.

"Grosserias" de Aécio - O candidato foi acusado de ser desrespeitoso com as mulheres ao qualificar de "levianas" as candidatas Luciana Genro e Dilma Rousseff em debates na TV.

Legado do PSDB no governo - Nas campanhas eleitorais de 2002, 2006 e 2010 os candidatos do partido (Geraldo Alckmin em 2006 e José Serra nas demais) pouco mencionaram o balanço dos oito anos do partido na presidência, com Fernando Henrique Cardoso, devido à percepção de impopularidade junto à opinião pública. Em 2014 Aécio fez referências mais frequentes às realizações de Cardoso, sobretudo a gestão do Plano Real, de combate à inflação, e a Lei de Responsabilidade Fiscal, que impôs limites a certos gastos públicos.

Máquina partidária do PSDB - A capilaridade do partido, bem superior à do PSB de Marina, era vista como um trunfo que dava a Aécio Neves maiores chances de bater Dilma Rousseff num eventual segundo turno.

Possível fim do PSDB - A perspectiva de um distante terceiro de lugar de Aécio no primeiro turno da eleição levou alguns analistas a prever a decadência do partido.

Privatizações - Defensor da iniciativa privada, o PSDB levou a cabo um programa de venda de empresas estatais, entre 1995 e 2002, que os opositores acusaram de lesar o interesse público.

Voto "silencioso" no PSDB - As pesquisas não refletiriam o real potencial de votos do partido porque os entrevistadores tenderiam a esconder a intenção de votar nele. 
Temas mencionados nas colunas de Eduardo van der Kooy no Clarín (26 textos) e Joaquín Morales Solá no La Nación (29 textos)

\section{Relacionados a Daniel Scioli}

Bom-mocismo de Scioli - Contradição entre a personalidade do candidato do governo, visto como conciliador, simpático e afável, e seu comportamento em certos momentos da campanha.

Campanha suja - A campanha de Scioli foi acusada de aplicar a "tática do medo" contra seus adversários, ao atribuir-lhes a intenção de cortar gastos sociais e adotar uma política econômica de austeridade.

Caso AMIA/Nisman/Stiuso - Em 1984, a explosão de um carro-bomba em frente à Associação Mutual Israelita de Buenos Aires matou 85 pessoas. A investigação arrastou-se por três décadas, com suspeitas concentradas sobre o papel do governo iraniano no atentado terrorista. Em janeiro de 2015, Alberto Nisman, fiscal encarregado do caso, foi encontrado morto no mesmo dia em que deveria ir ao Congresso apresentar novas evidências, para as quais teria contribuído o espião Jaime Stiuso. Cristina Fernández foi acusada de negociar com o Irã o acobertamento do caso

Corrupção no governo - Suspeitas diversas levantadas sobre atos da administração de Cristina Fernández.

Eleições em Tucumán - Em 23 de agosto foi realizada a eleição para o governo provincial de Tucumán. Houve acusações de fraude em benefício do candidato da Frente para a Vitória, Juan Luis Manzur. Após uma anulação inicial do pleito, a Justiça confirmou a vitória de Manzur.

Fim do kirchnerismo - Suposta decadência da corrente peronista liderada por Cristina Fernández e, antes, por seu marido Néstor Kirchner.

Fondos buitre - São os "fundos abutre", que investem em "papéis podres", de alto risco, na esperança de obter lucro posterior com ações na Justiça. Fundos americanos que possuíam títulos da dívida argentina não aceitaram os termos da reestruturação da dívida propostos por Néstor Kirchner aos credores em 2005. Em 2011, esses fundos conseguiram uma decisão favorável em um tribunal de Nova York, pondo em risco o esforço da Argentina para retornar ao mercado internacional de títulos.

Fraude eleitoral - Risco de ocorrência de irregularidades no pleito, como o desaparecimento de cédulas da oposição e suspeitas sobre o papel dos Correios no transporte das urnas.

Gastos desenfreados - $\mathrm{O}$ governo foi acusado de irresponsabilidade nas despesas públicas, com contratações de apadrinhados políticos e gastos sociais sem fonte garantida de receita. 
Gildo Insfrán x Carlos Tevez - Insfrán, governador kirchnerista da província de Formosa, é acusado de vínculos com o narcotráfico. Em 2015, envolveu-se numa polêmica com Tevez, um dos mais populares jogadores de futebol argentino, que criticou a pobreza "muito grande" na província.

Guerra contra os meios - Ao longo dos mandatos de Cristina Fernández aprofundou-se o conflito entre a presidente e os grandes grupos de comunicação, sobretudo os proprietários do jornal Clarín. A Ley de Medios de 2009 estabeleceu limite ao número de concessões de rádio e televisão que um mesmo grupo pode possuir, atingindo sobretudo o Grupo Clarín.

Influência sobre a Justiça - Acusação ao Executivo de interferência sobre o Poder Judiciário, na nomeação de juízes e na influência política sobre eles.

Juízes eleitorais - O papel da Justiça Eleitoral argentina no controle da lisura das eleições e a possível influência do governo sobre a nomeação e o trabalho desses juízes.

Narcotráfico - Durante a campanha diversos políticos, sobretudo do governo, foram acusados de ligações com o tráfico de drogas, o mais proeminente deles o chefe de gabinete de Cristina, Aníbal Fernández (sem parentesco com a presidente).

Peronismo radical - Alas do peronismo kirchnerista, como a denominada La Cámpora, comandada por Máximo, filho de Cristina e Néstor Kirchner, foram acusadas de truculência em seus métodos.

Perspectiva ruim da economia - A piora dos indicadores da economia em 2015 e as previsões pessimistas em relação à inflação, ao desemprego e ao déficit público para 2016.

Relação de Cristina-Scioli - O candidato do governo foi acusado de falta de independência em relação à presidente; esta foi acusada em determinados momentos da campanha de boicotar o próprio candidato a sucedê-la.

Tweets - Guerra travada nas redes sociais, com acusações mútuas de lançamento de boatos contra candidaturas adversárias.

\section{Relacionados a Mauricio Macri}

Caso Fernando Niembro - Locutor esportivo consagrado, Niembro foi acusado de receber valores indevidos em contratos publicitários com o governo da Cidade Autônoma de Buenos Aires, na gestão de Macri. O escândalo levou Niembro a renunciar a sua candidatura a deputado nacional, em que encabeçava a lista do partido de Macri. 
Corrupção na oposição - Acusações diversas contra atos de políticos ligados a Macri.

Desvalorização do peso - Perspectiva de queda de valor, após as eleições, da moeda argentina, cujo valor estaria sendo artificialmente sustentado pelo governo por cálculo eleitoral.

Governabilidade - Referências a possíveis dificuldades para Mauricio Macri governar, uma vez eleito, pela falta de maioria parlamentar.

\section{Relacionados a Sergio Massa}

Governabilidade - Referência a possíveis dificuldades para Mauricio Macri governar, uma vez eleito, pela falta de maioria parlamentar. 
Apêndice II - Manchetes de primeira página de $O$ Estado de S. Paulo e de $O$ Globo relativas a pesquisas eleitorais, no período entre 15 de agosto e 26 de outubro de 2014

O Estado de S. Paulo (13 manchetes principais, 3 manchetes secundárias)

\begin{tabular}{|l|l|l|}
\hline Data & Instituto citado & Manchete \\
\hline 27 ago. & Ibope & "Marina se descola de Aécio e venceria Dilma no 2o turno" \\
\hline 30 ago. & Datafolha & "Marina empata com Dilma no 10 turno, diz pesquisa" \\
\hline 4 set. & Ibope & $\begin{array}{l}\text { "Dilma sobe } 3 \text { pontos, mas Marina venceria no 2o turno, diz } \\
\text { Ibope" }\end{array}$ \\
\hline 11 set. & Datafolha & $\begin{array}{l}\text { "Dilma e Marina aparecem em empate técnico no 2o turno" } \\
\text { (segunda manchete principal) }\end{array}$ \\
\hline 13 set. & Ibope & "Dilma tem 39\% e Marina, 31\% no 10 turno, diz Ibope" \\
\hline 17 set. & Ibope & "Dilma cai, Marina estaciona e Aécio sobe, aponta Ibope" \\
\hline 24 set. & Ibope & "Dilma abre 9 pontos sobre Marina no 1o turno, diz Ibope" \\
\hline 27 set. & Datafolha & "Dilma abre 13 pontos sobre Marina no 10 turno e lidera 2" \\
\hline 1 out. & Ibope/Datafolha & "Dilma abre 14 pontos; disputa entre Marina e Aécio se acirra" \\
\hline 5 out. & Ibope/Datafolha & "Dilma abre vantagem; Marina mantém tendência de queda" \\
\hline 10 out. & Ibope & "Ibope mostra Aécio à frente de Marina em empate técnico" \\
\hline 16 out. & Ibope/Datafolha & $\begin{array}{l}\text { "Ibope: Aécio tem 51\% e Dilma, 49\%, em empate técnico" } \\
\text { (segunda manchete principal) }\end{array}$ \\
\hline 21 out. & Datafolha & (segunda manchete principal) \\
\hline 24 out. & Ibope & "Dilma tem 52\% e Aécio, 48\% em empate técnico, diz pesquisa" \\
\hline 26 out. & Ibope/Datafolha & "Pesquisas apontam eleição mais acirrada desde 1989" \\
\hline
\end{tabular}

O Globo (13 manchetes principais, 2 manchetes secundárias)

\begin{tabular}{|l|l|l|}
\hline Data & Instituto citado & Manchete \\
\hline 27 ago. & Ibope & "Marina se distancia de Aécio e venceria Dilma no 2o turno" \\
\hline 30 ago. & Datafolha & $\begin{array}{l}\text { "Datafolha: Marina empata com Dilma e vence no 2o turno" } \\
\text { (segunda manchete principal) }\end{array}$ \\
\hline 4 set. & Ibope/Datafolha & "Dilma reage nas pesquisas e fala em mudar equipe" \\
\hline 11 set. & Datafolha & $\begin{array}{l}\text { "Apesar da pancadaria, quadro fica inalterado" (segunda } \\
\text { manchete principal) }\end{array}$ \\
\hline 17 set. & Ibope & "Ibope: Dilma perde dois pontos nos dois turnos da eleição" \\
\hline 24 set. & Ibope & "Dilma abre 9 pontos de vantagem sobre Marina" \\
\hline 27 set. & Datafolha & "Dilma amplia vantagem e passa Marina no 2o turno" \\
\hline 1 out. & Ibope/Datafolha & "Marina volta a cair e já é ameaçada por Aécio" \\
\hline 3 out. & Ibope/Datafolha & "Adversário de Dilma no 2o turno está indefinido" \\
\hline 5 out. & Ibope/Datafolha & "No último dia, Aécio passa Marina e pode ir ao 2o turno" \\
\hline 10 out. & Ibope/Datafolha & "Aécio sai na frente, em empate técnico com Dilma" \\
\hline 16 out. & Ibope/Datafolha & "Disputa fica estável apesar de agressões" \\
\hline 21 out. & Datafolha & "Dilma passa Aécio, mas empate técnico continua" \\
\hline 24 out. & Ibope/Datafolha & "Dilma descola de Aécio" \\
\hline 26 out. & Ibope/Datafolha & "Aécio volta a subir e encosta em Dilma" \\
\hline
\end{tabular}


Apêndice III - Manchetes de primeira página do Clarín e de La Nación relativas a pesquisas eleitorais, nos períodos entre 19 de agosto e 22 de novembro de $2015^{83}$

Clarín (6 manchetes principais, 1 manchete secundária)

\begin{tabular}{|l|l|l|}
\hline Data & Instituto citado & Manchete \\
\hline 4 out. & Management \& Fit & "Más ventaja de Scioli, pero la elección sigue indefinida" \\
\hline 17 out. & Management \& Fit & "Hasta hoy habría balotaje para eligir al Presidente" \\
\hline 18 out. & Nenhum específico & $\begin{array}{l}\text { "Los candidatos van por los indecisos y los que cambiarían el } \\
\text { voto" }\end{array}$ \\
\hline 8 nov. & Management \& Fit & $\begin{array}{l}\text { "Cierre de campaña: los candidatos apuntaron al voto de los } \\
\text { indecisos" }\end{array}$ \\
\hline 14 nov. & Management \& Fit & $\begin{array}{l}\text { "Macri mantiene la ventaja sobre Scioli a ocho dias del } \\
\text { balotaje" (manchete secundária) }\end{array}$ \\
\hline 17 nov. & Nenhum específico & $\begin{array}{l}\text { "Scioli intenta acortar la distancia, sin Cristina en el final de la } \\
\text { campaña" }\end{array}$ \\
\hline
\end{tabular}

La Nación (6 manchetes principais, 1 manchete secundária)

\begin{tabular}{|l|l|l|}
\hline Data & Instituto citado & Manchete \\
\hline 27 set. & Ipsos/Isonomía & $\begin{array}{l}\text { "A Scioli y a Macri les cuesta crecer y no logran polarizar" } \\
\text { (manchete secundária) }\end{array}$ \\
\hline 20 out. & Poliarquía & $\begin{array}{l}\text { "Scioli lidera, pero aún no se asegura un triunfo en la primera } \\
\text { vuelta" }\end{array}$ \\
\hline 1 nov. & $\begin{array}{l}\text { Management \& Fit, } \\
\text { Isonomía, Raúl } \\
\text { Aragón \& } \\
\text { Asociados }\end{array}$ & $\begin{array}{l}\text { "Macri y Massa llaman a evitar un triunfo de Scioli en primera } \\
\text { vuelta" }\end{array}$ \\
\hline 21 nov. & $\begin{array}{l}\text { Poliarquía } \\
\text { Panagementioción limita a Scioli y Macri amplía su techo" } \\
\text { González y } \\
\text { Valladares, Elypsis }\end{array}$ & $\begin{array}{l}\text { "Macri consolida su ventaja sobre Scioli en la recta final al } \\
\text { ballottage" }\end{array}$ \\
\hline 22 nov. & $\begin{array}{l}\text { Nonhum específico } \\
\text { persisten" }\end{array}$ & $\begin{array}{l}\text { "En un ballotage histórico, Macri y Scioli disputan la } \\
\text { presidencia" }\end{array}$ \\
\hline
\end{tabular}

${ }^{83}$ Como a lei eleitoral argentina proíbe a divulgação de pesquisas nos oito dias que antecedem cada turno eleitoral, as referências a pesquisas nos meios de comunicação, nos períodos entre 18 e 25 de outubro e 15 e 22 de novembro, não podiam fazer menção específica a números de intenções de voto. 
